\title{
THE INTERNATIONAL IMPACT OF MACROPRUDENTIAL POLICIES
}

\author{
by
}

\section{DORIANE INTUNGANE}

M.A. Economics, University of Windsor, 2012

B.A. Economics and International Trade, Universite du Lac Tanganyika, 2008

\author{
A dissertation presented to Ryerson University \\ in partial fulfillment of the \\ requirements for the degree of \\ Doctor of Philosophy \\ in the Program of Economics
}

Toronto, Ontario, Canada, 2019

(C) Doriane Intungane, 2019 


\section{Author's Declaration}

I hereby declare that I am the sole author of this dissertation. This is a true copy of the dissertation, including any required final revisions, as accepted by my examiners.

I authorize Ryerson University to lend this dissertation to other institutions or individuals for the purpose of scholarly research.

I further authorize Ryerson University to reproduce this dissertation by photocopying or by other means, in total or in part, at the request of other institutions or individuals for the purpose of scholarly research.

I understand that my dissertation may be made electronically available to the public. 
The International Impact of Macroprudential Policies

Doctor of Philosophy, 2019

Doriane Intungane

Economics, Ryerson University

The recent financial crisis started a global debate on the role of financial policies, which led to financial system reforms in many countries. These reforms mainly consisted of increasing the usage of macroprudential policies. This dissertation seeks to understand whether macroprudential policies in financially integrated countries reduced their vulnerability to the impact of external shocks. Chapter 2 empirically examines the impact of macroprudential policies on cross-border bilateral credit growth. Capital requirements and loan-to-value (LTV) ratios, in 15 lending countries and 34 borrowing countries between 2000 and 2014, are used in the analysis. The results show that in some countries, the increase of capital requirements is not effective in reducing international credit flows during periods of financial vulnerability. The impact of tightening LTV ratios is more heterogeneous across countries because LTV ratios are mainly used in the housing sector and not all countries change their LTV ratio frequently. Hence, cooperation across countries is necessary but also countries should make sure that the change of macroprudential policies targeting lenders and those targeting borrowers complement each other to avoid international leakages. Chapter 3 analyzes issues related to the international spillover of macroprudential policies through international banking activities using a two-country dynamic stochastic general equilibrium model with heterogeneous and time-varying macroprudential policies. The results show that a combination of capital requirements and LTV ratios is effective in reducing credit growth despite the existence of cross-border banking activities and heterogeneous implementation of capital requirements across countries. In addition, international coordination of capital requirements is also effective in reducing credit growth but less effective than a combination of capital requirements and LTV ratios. 
Chapter 4 focuses on the role of countercyclical LTV ratios in reducing transmission of shocks when international investors, holding domestic and foreign assets, face collateral constraint. Using a two-country dynamic stochastic general equilibrium model, the analysis demonstrates that time-varying LTV ratios can reduce the transmission of shocks. 


\section{Acknowledgments}

I owe my deepest gratitude to my supervisor Professor Maurice Roche for his guidance, effort and for his availability. I am also grateful for Professor Claustre Bajona, Professor Derek Stacey for their inestimable advice, suggestions and encouragement. Your support did not go unnoticed. I thank all the Macro-Workshop participants. My research benefited so much from comments and suggestions I received from the workshops. I appreciate the positive learning environment of the Economics Department at Ryerson University. I would like to thank all my classmates for making the days we spent together agreeable, for their friendship and for their academic support.

Last but not least, I thank my family for their support and encouragement throughout the process of completing my studies. I would like to give special thanks to Alain-Desire for being my mentor and my go to person whenever I needed help. I am indebted to my husband, Gustave, for his companionship, encouragement, patience and love during this journey. 


\section{Dedication}

To my late father, my mom, my sisters and my brother

To my husband 


\section{Contents}

$\begin{array}{ll}\text { Abstract } & \text { iii }\end{array}$

$\begin{array}{ll}\text { List of Tables } & \text { ix }\end{array}$

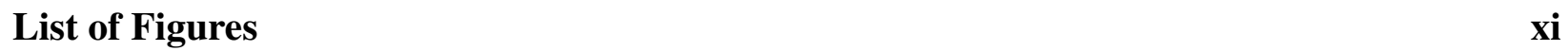

List of Appendices $\quad$ xii

1 Introduction $\quad 1$

2 The Role of International Credit on the Effectiveness of Macroprudential Policies 8

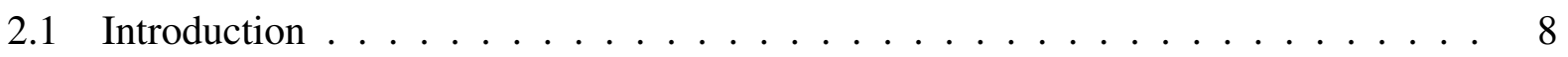

2.2 Literature Review . . . . . . . . . . . . . . . . . . . . . . 14

2.3 Empirical analysis and methodology . . . . . . . . . . . . . . . . . . 19

2.4 Robustness check . . . . . . . . . . . . . . . . . 30

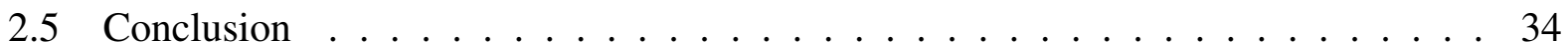

3 Interaction of Heterogeneous Macroprudential Policies 36

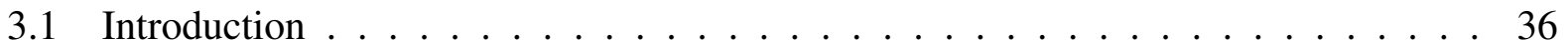

3.2 Literature Review . . . . . . . . . . . . . . . . . . . . . . 42

3.3 Model . . . . . . . . . . . . . . . . . . . . . . 47

3.4 Parameters values . . . . . . . . . . . . . . . . . 58

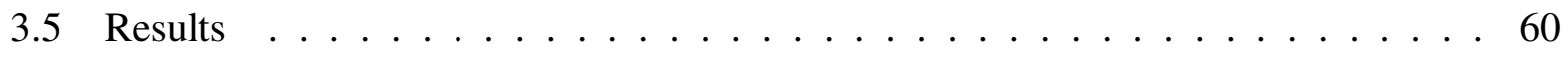




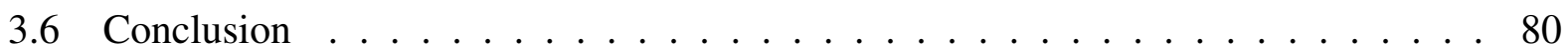

4 The Impact of Macroprudential Policies on the Transmission of Shocks 82

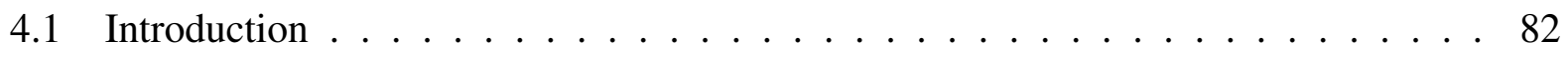

4.2 Related Literature . . . . . . . . . . . . . . . . . . . . . . . 86

4.3 Model . . . . . . . . . . . . . . . . . . . . . . . . . 91

4.4 Parameters values $\ldots \ldots \ldots$

4.5 Moments and impulse response results $\ldots \ldots \ldots 10 \ldots$

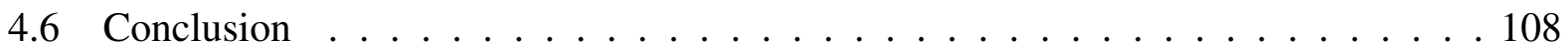

$\begin{array}{llr}5 & \text { Summary and Conclusion } & 109\end{array}$

$\begin{array}{ll}\text { Appendix A: Additional Tables - Chapter 2 } & 113\end{array}$

$\begin{array}{ll}\text { Appendix B: Other Results-Chapter2 } & 117\end{array}$

$\begin{array}{ll}\text { Appendix C: Figures-Chapter } 3 & 126\end{array}$

$\begin{array}{ll}\text { Appendix D: Figures-Chapter } 4 & 151\end{array}$

$\begin{array}{ll}\text { Bibliography } & 154\end{array}$ 


\section{List of Tables}

2.1 Transmission channels of macroprudential policies $\ldots \ldots \ldots$. . . . . . . . . 9

2.2 Effects of capital requirements on bilateral cross-border credit from advanced countries . . 27

2.3 Effects of the LTV ratio on bilateral cross-border credit from advanced countries _ . . . 29

2.4 Effects of capital to asset ratio on bilateral cross-border credit from Advanced countries . . 31

2.5 Effects of LTV Ratio on bilateral cross-border credit from advanced countries . . . . . . . 33

3.1 LTV ratio in the housing sector in different countries $\ldots \ldots \ldots 38$

3.2 Capital requirements in different countries . . . . . . . . . . . . . . 39

3.3 Parameters values $\ldots \ldots \ldots \ldots \ldots$

3.4 International business cycle moments $\ldots \ldots \ldots \ldots 2 \ldots \ldots \ldots$

3.5 Parameters for experiments $\ldots \ldots \ldots \ldots \ldots \ldots$

$4.1 \quad$ Parameters values . . . . . . . . . . . . . . . . . . . . 100

4.2 International business cycle moments $\ldots \ldots \ldots 101$ 


\section{List of Figures}

2.1 Bilateral cross-border credit $\ldots \ldots \ldots \ldots$

2.2 Debt service ratio $2000-2014 \ldots \ldots \ldots \ldots$

3.1 Effect of heterogeneous policies on credit build up under high and low cross-border

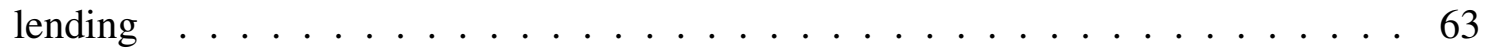

3.2 Effect of heterogeneous policies on financial indicators - Productivity shock . . . . 64

3.3 Effect of heterogeneous policies on financial indicators - Borrowing capacity shock 65

3.4 Effect of heterogeneous LTV ratio on credit build up under high and low cross-

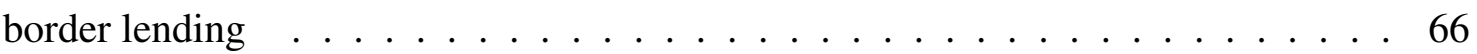

3.5 Responses of key macroeconomic variables to a domestic productivity shock . . 68

3.6 Responses of key macroeconomic variables to a domestic borrowing capacity shock 69

3.7 Effect of heterogeneous capital requirements on credit build up under high and low cross-border lending . . . . . . . . . . . . . . . . . . . . . . . . . 69

3.8 Responses of key macroeconomic variables to a domestic productivity shock $\ldots 71$

3.9 Responses of key macroeconomic variables to a domestic borrowing capacity shock 72

3.10 Cross-border coordination of heterogeneous capital requirements . . . . . . . . . 74

3.11 Responses of key macroeconomic variables to a domestic productivity shock $\ldots 75$

3.12 Responses of key macroeconomic variables to a domestic borrowing capacity shock 76

3.13 Complementary policies under high cross border lending $\ldots \ldots \ldots$. . . . . 77

3.14 Responses of key macroeconomic variables to a domestic productivity shock $\ldots 78$

3.15 Responses of key macroeconomic variables to a domestic borrowing capacity shock 79 
4.1 FDI and GDP growth $\ldots \ldots \ldots \ldots$

4.2 Impulse responses following a negative productivity shock in the home country . . 104

4.3 Impulse responses following a negative borrowing capacity shock in the home

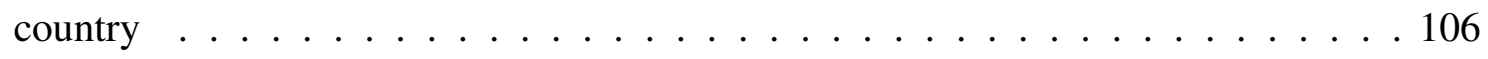

4.4 LTV responses to productivity and borrowing capacity shocks $\ldots \ldots 107$ 


\section{List of Appendices}

Appendix A : Additional Tables - Chapter 2 .............................................................113

Appendix B : Other Results - Chapter 2 ....................................................................117

Appendix C : Figures - Chapter 3.................................................................................126

Appendix D : Figures- Chapter 4................................................................................151 


\section{Chapter 1}

\section{Introduction}

The financial crisis in 2007 triggered an important debate on the role of financial policies in reducing economic vulnerability to external shocks to improve economic stability in many countries. Since then, financial system reforms have been introduced in many countries, especially those affected by the crisis, to prevent future financial crises. These reforms consist of an increase in the use of "macroprudential policies". According to Cerutti et al. (2016), the objective of macroprudential policies is to increase the resilience of both individual firms and the financial system to shocks, and to reduce the build up of financial vulnerabilities by minimizing the rapid increase and volatility of asset prices and credit over time. In addition, they control structural vulnerabilities arising through interlinkages (by reducing interdependence between financial institutions within and across countries for example) and reduce the importance of individual intermediaries in key markets that can render individual institutions "too big to fail". The goal of macroprudential policies can also be understood as policies implemented to reduce financial systemic risk. ${ }^{1}$ These policies complement existing policies such as microprudential policies and other macroeconomic policies. There are different types of macroprudential policies; some focus on the control and management of capital in the banking sector and others target borrowers' accessibility to credit. Among the prudential policies which have been used around the world are bank capital requirements, counterparty con-

\footnotetext{
${ }^{1}$ Schwarcz (2008) defines systemic risk as an economic shock or an institutional failure, which causes a chain of negative economic consequences such as a dramatic increase of financial market price volatility and the inability of financial markets and institutions to provide regular financial services.
} 
centration limits, interbank exposure limits, loan-to-value ratio (LTV ratio), and reserve requirements. This dissertation analyzes international impact of bank capital requirements (also known as the capital adequacy ratio) and LTV ratio policies. This choice is based on the frequent usage of these policies in many countries. Cerutti et al. (2016) show that LTV ratio limits are among the tools which have been changed more than others between 2000 and 2014. A recent European Banking Authority report (European Banking Authorithy, 2015) shows that the management of countercyclical capital buffers is heterogeneous in financially linked countries, although the Basel III agreement (BIS, 2015) urges integrated countries to implement reciprocal policies.

Understanding the global impact of these two types of macroprudential policies is important for many reasons. First, based on the Basel III recommendations, many countries increased (or are in the process of increasing) capital requirements. Second, the two macroprudential policies we consider affect the international banking conditions. Ccapital requirements influence credit supply domestically and internationally and LTV ratios limit the ability of the borrowers to demand credit. In addition, recent evidence highlights differences in the composition and tightness of prudential instruments across countries (see Cerutti et al., 2016). For example, we observe a frequent usage of LTV ratios in emerging countries compared to advanced countries, while general capital requirements have increased in all countries but at different levels. ${ }^{23}$ This means that the effectiveness of the policies can diminish if economic agents can evade the financial regulations by increasing international banking activities. For example, Aiyar et al. (2012) find that macroprudential capital requirements implemented in the UK cannot fully control aggregate credit supply due to the existence of unregulated (or less regulated) alternative sources of credit (domestic financial institutions and foreign banks) which increase credit supply to borrowers while regulated banks reduce credit supply due to the increase in capital requirements. The literature on the international impact of macroprudential policies shows that countries such as the USA, the Netherlands, Germany, Canada, etc., have increased international banking activities with countries with more strict pruden-

\footnotetext{
${ }^{2}$ The sudden increase of housing price and credit extension after the global financial crisis explain the frequent usage of LTV ratio (Jacome and Mitra (2015)) in many advanced economies.

${ }^{3}$ See 2015 European Banking Authority report.
} 
tial tools. ${ }^{4}$ Simultaneously, financial openness plays an important role in global economic stability by amplifying the influence of worldwide financial conditions on the ability of policymakers to regulate domestic financial conditions. ${ }^{56}$ The rise of countries' financial interconnection increases the risk of transmission of external shocks (see for example Dedola and Lombado (2012), Poutineau and Vermandel (2015)). In fact, financial openness has increased around the world from about 36\% of GDP in 1960 to 400\% in 2015 (BIS, 2017). Developed countries experienced a higher expansion of investment in cross-border financial assets and liabilities in the mid-1990s going from $135 \%$ of GDP to $570 \%$ of GDP in 2015 . Emerging countries also experienced a rise of cross-border financial assets and liabilities from $100 \%$ to $180 \%$ of GDP over the same period of time (BIS, 2017). Despite the magnitude of the recent financial crisis which reduced international financial activities, global financial conditions still influence the level, between $20 \%$ to $40 \%$, of domestic financial conditions indices, particularly in emerging countries (IMF, 2017). ${ }^{7}$ In addition, the recovery of many countries from the 2007 financial crisis has caused a slow increase of foreign direct investment (FDI) inflows of 5\% in developed countries in 2016 and an increase of only 2\% in developing countries in 2017 (UNCTAD 2016; 2017). ${ }^{8}$ Furthermore, financial reforms involving the increased usage of macroprudential policies has caused international spillovers of these policies in many countries. For example, researchers report that in some countries such as Canada, Germany, the USA, and the Netherlands cross-border banking activities have increased between these countries and other countries with more strict macroprudential policies which can mitigate domestic lending. The literature suggests that these changes can be explained by the difference in usage of macroprudential policies. ${ }^{9}$ In addition, coordination of macroprudential policies across countries has been suggested in the literature but one of the issues that remains unresolved is that

\footnotetext{
${ }^{4}$ See for example, Buch and Goldberg (2016), Ohls et al. (2016), Frost et al.(2016).

${ }^{5}$ Financial openness is measured as the value of investment assets held by foreigners as a share of GDP.

${ }^{6} \mathrm{IMF}$ (2017) defines financial conditions as the ease in obtaining finance.

${ }^{7}$ Global financial conditions refer to the easiness of obtaining financing from international markets.

"Financial condition indices" are indices calculated using financial information related to interest rate, the cost of credit for various agents in the economy.

${ }^{8}$ These rise of FDI inflows were lower than expected in those two groups of countries.

${ }^{9}$ See for example Avdjiev et al. (2016), Ohls et al. (2016) and Damar and Mordel (2016).
} 
of the efficient formulation of coordinated macroprudentialpolicies. ${ }^{10}$ In this dissertation, we investigate the impact heterogeneous macroprudential policies on credit build up at the international level and we give a recommendation on how macroprudential policies should be implemented to increase their efficiency in minimizing credit build up in financially integrated countries.

In Chapter 2, we conduct panel data analysis to study the impact of both lending and borrowing countries' macroprudential policies on aggregate cross-border credit growth (defined as bilateral credit supplied by foreign banks) during a period of rapid credit growth. This is a particular time of the business cycle where macroprudential policies change based on the state of the economy. The goal is to understand whether excessive credit growth (excessive credit growth refers to a deviation of credit growth from its average) can increase financial vulnerability with international banking activities despite the implementation of prudential instruments. We explore the impact of both lending and borrowing countries' prudential policies on cross-border credit growth to understand the role of international coordination across countries on the effectiveness of macroprudential tools. Unlike in the literature studying the impact of lending and borrowing countries' macroprudential policies, we use aggregate banking data and consider debt service ratio of the non financial private sector borrowers. Thedebt service ratio is an early warning indicator considered to be our measure of financial vulnerability. Capital requirements and LTV ratios are the selected macroprudential policies for the assessment as they have changed in many countries involved in cross-border banking activities (see Cerutti et al. 2016).

The findings show that an increase of capital requirements of lending and borrowing countries reduces cross-border credit because it reduces banks' credit supply in most countries. However, the increase of capital requirements during a credit boom reduces by less credit growth originating from bilateral cross-border lending and the impact differs with the group of lending and borrowing countries considered. In fact, credit booms often coincide with times of high productivity and high credit demand and lending, which explains the low significant effect and the different effect this policy has across countries. LTV ratios have an heterogeneous impact on bilateral cross-border

\footnotetext{
${ }^{10}$ See for example, Buch and Goldberg (2016), Frost et al.(2016), Ohls et al. (2016) and Damar and Mordel (2016).
} 
credit growth (the magnitude of the change in bilateral credit varies by group of countries analysed) at the international level compared to the effects of capital requirements. Two factors explain the response of bilateral credit due to a change in LTV ratios. First, both domestic and foreign lenders apply the same LTV ratios to borrowers of a specific country. This explains the effects of LTV ratios on cross-border credit are different from those of capital requirements. Second, the LTV ratios change by sector. In this analysis, we consider a change in LTV ratios in the housing sector. This study suggests that capital requirements need to be more coordinated across countries compared to LTV ratios. The reduced impact of the policies on credit growth during a credit boom suggest that openness to banking activities and complementarity of domestic policies targeting lenders and borrowers should be considered while implementing macroprudential policies to minimize credit growth in countries opened to cross-border lending.

The goal of the third chapter is to evaluate the effect of heterogeneous macroprudential policies on credit demand and the propagation of shocks across countries open to cross-border lending. A two-country dynamic stochastic general equilibrium model is used in the analysis. The policies considered are the LTV ratio and capital requirements ( also known as the capital adequacy ratio) which are formulated in Taylor-type rules. Different experiments are used to analyze the dynamic responses of credit build up to shocks across countries under heterogeneous macroprudential policies. ${ }^{11}$ The first contribution of this chapter is to show the impact of two different macroprudential policies in a two country model with banking sector considering openness to cross-border banking activities. The main results suggest that the effectiveness of capital requirement financial regulations may be undermined by cross-border lending activities, if borrowers can increase credit from foreign banks operating in a country with more relaxed capital requirements. The impact of openness to cross-border credit on the performance of LTV ratios is less observable than capital requirements dues to the fact that domestic and foreign lenders all apply the same level of LTV ratio to borrowers from the same country. We find that when cross-border lending is permitted, national financial regulators can improve management and regulation of credit growth by implementing

\footnotetext{
${ }^{11}$ Two types of shocks are considered: a productivity shock and a borrowing capacity shock.
} 
both the capital adequacy ratio and LTV ratios that are time varying and adjusting with country's financial conditions. The second contribution is to demonstrate in a two-country model setting that implementing macroprudential policies which complement each other on borrowers and on lenders is beneficial on controling credit buildup in countries open to cross border lending activities. The two macroprudential policies are able to control credit growth at both ends. It means that the credit supply is limited by the implementation of capital adequacy ratios and borrowing is limited by the LTV ratio which reduces the maximum loan a borrower can receive. Another solution which can help to reduce credit build up, in the long run, is international coordination of the capital adequacy ratios.

In Chapter 4, we extend the literature studying the transmission of shocks across countries by analyzing how the time-varying LTV ratios can reduce the transmission of shocks across countries. ${ }^{12}$ Hence, a two-country model with time-varying LTV ratio prudential tools is used for the assessment. The contribution to the literature is to show the benefits of the time-varying LTV ratios, also known as countercyclical LTV ratios, compared to constant LTV ratio in mitigating the severity of negative productivity and financial shocks and their transmission across countries. We find that countercyclical LTV ratios mitigate the transmission of shocks by reducing the comovement and volatility of key variables across financially linked countries when one of the countries experiences a negative productivity or financial shock. This effect is explained by the fact that countercyclical LTV ratios take into account the change of financial indicators. In this analysis, we consider that the LTV ratio changes with the variation of credit growth. The LTV ratio tightens as credit increases relative to its steady state value. The results show that the macroprudential policies reduce volatility of financial variables and therefore have a stronger impact under a financial shock than under a productivity shock. As LTV ratios target to reduce the variation of financial variables, they reduce the effect of negative shocks on the value of equity, credit growth and equity investment. We find that there exists a welfare gain for all economic agents in financially integrated countries when time-varying LTV ratios are implemented. Since the policies are countercyclical,

\footnotetext{
${ }^{12}$ We study the transmission of productivity and financial shocks.
} 
they increase the value of pledged assets (equities in our model) when there is a negative shock; allowing investors to have access to credit and continue investing and producing goods in times of crisis. 


\section{Chapter 2}

\section{The Role of International Credit on the Effectiveness of Macroprudential Policies}

\subsection{Introduction}

The implementation of macroprudential requirements which followed the 2007 financial crisis reduced cross-border bank lending differently across countries. The literature suggests that there has been an increase of cross-border spillovers on bank lending due to prudential regulation because of differences in the tightness of the macroprudential policies across countries and the supervision by a country's central bank of these financial regulations (see for example Bremus and Fratzscher (2015), Berrospide et al. (2015), Frost et al. (2016), Ohls et al. (2016)) assess how national and cross-border banking activities have changed in Germany since the implementation of financial regulation in the form of macroprudential policies. They find that, after the global financial crisis, cross-border bank lending increased between Germany and foreign countries in which prudential regulation had different degrees of tightness compared to Germany. Damar and Mordel (2016) find similar results in Canada where countries with strict financial regulation tools have increased cross-border credit demand with Canadian global banks as opposed to countries with loose policies. Studies on the effectiveness of macroprudential policies implemented in countries, such as 
the United States of America (USA), the Netherlands, and the United Kingdom (UK) have come to the same conclusion that cross-border banking activities increased between countries with heterogeneous macroprudential policies.

Buch and Goldberg (2017) identify how countries have shifted international bank lending through two different transmission channels : inward transmission and outward transmission channels. The inward transmission channel is the effect foreign regulation has on domestic banking activities. The outward transmission channel changes how foreign macroprudential policies affect foreign banking activities. Table 2.1 gives a list of few countries which changed their international banking activities under the two transmission channels. Aiyar et al. (2012) use bank-level data to investigate the impact that changes in capital requirements for UK banks has on credit supply. They find that foreign bank branches operating in the UK increased credit supply in the UK as a consequence of a decline of credit supply by UK regulated banks. For example, a $1 \%$ reduction in lending by regulated UK banks, due to the tightness of capital requirements, causes an increase of $2.67 \%$ in lending by foreign bank branches in the UK. Hence, regulated banks lend about 9.5 million British pounds to the domestic borrowers and foreign banks lend 630,000 British pounds ${ }^{1}$.

Table 2.1: Transmission channels of macroprudential policies

\begin{tabular}{|c|c|}
\hline Inward Transmission Channel & Outward Transmission Channel \\
\hline \hline $\begin{array}{c}\text { Chile, Germany, Mexico, Portugal, Switzerland, } \\
\text { Turkey, United Kingdom, United States }\end{array}$ & $\begin{array}{c}\text { Canada, France, Germany, Hong Kong, } \\
\text { Italy, Netherlands, United States }\end{array}$ \\
\hline
\end{tabular}

Source: Buch and Goldberg (2017)

Figure 2.1 below shows how bilateral cross-border lending in thirty four countries evolved between 2000 and 2014. Despite the fact that many large banks in advanced countries have withdrawn from foreign credit markets, the stock of bilateral cross-border credit is more pronounced in advanced economies than in emerging countries. However, in emerging countries we observe that cross-border credit was less affected by the financial crisis compared to advanced economies as it is still rising even after the financial crisis. According to Bremus and Fratzscher (2015), the

\footnotetext{
${ }^{1}$ Overall, the foreign branches increased lending by in the UK about $30 \%$ due to tightness of capital requirements imposed on UK banks.
} 
difference in monetary and financial regulatory policies explain this difference evolution of cross border bank lending.

Figure 2.1: Bilateral cross-border credit

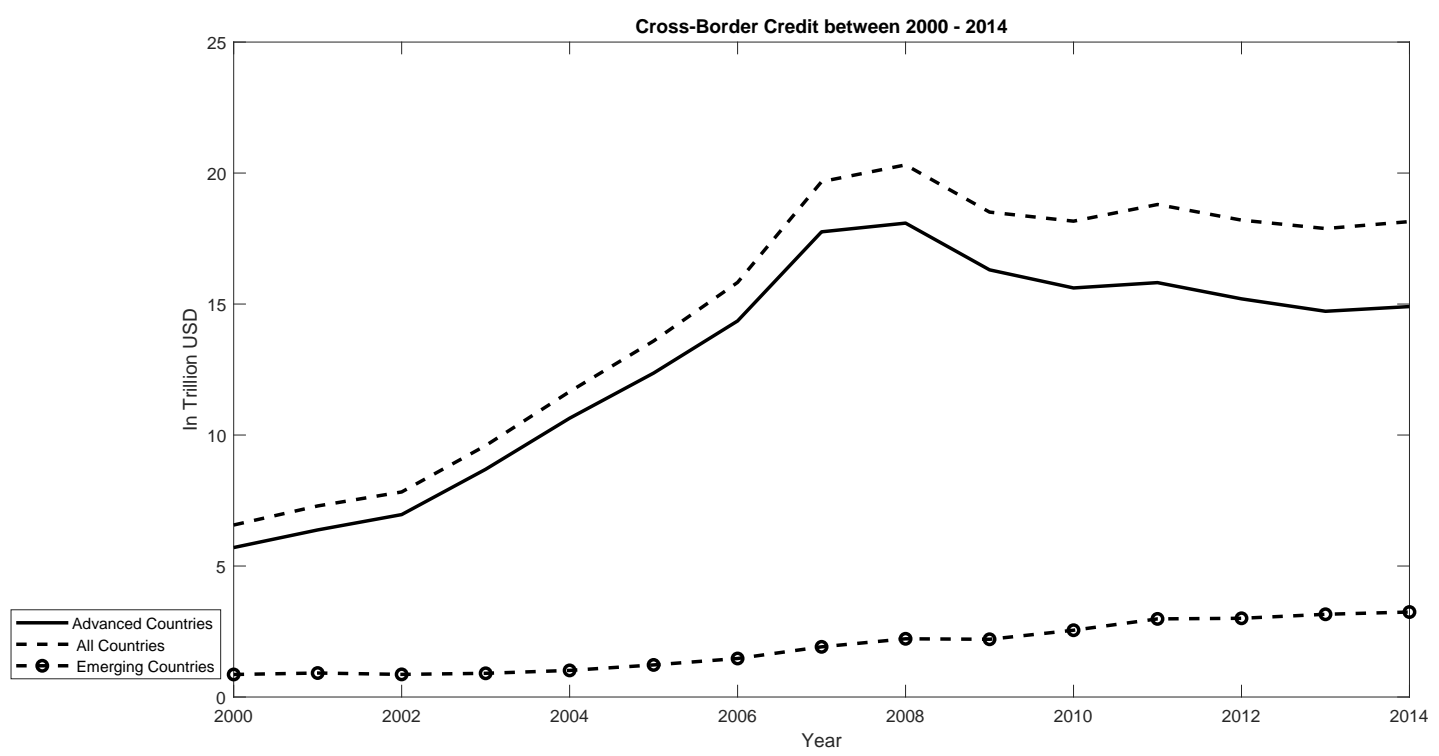

Source of credit : 15 Advanced economies. Destination of credit: 34 selected countries. Data source : BIS Consolidated banking statistics, immediate borrowers basis.

As a result of much research many of these economists recommend the establishment of international coordination of macroprudential policies. ${ }^{2}$ In addition, the Basel Committee (see BIS (2015), (2017)) acknowledges the need of an international harmonization of macroprudential policies and recommends the implementation of reciprocal macroprudential policies to reduce international spillover of macroprudential policies. ${ }^{3}$ In this chapter, we analyze how bilateral credit responds to the implementation of macroprudential policies in the lending and borrowing countries. In particularly, we analyze how the difference in usage of the policies undermines the objective of the policies, which to curb credit growth during credit boom. We contribute to the literature

\footnotetext{
${ }^{2}$ See for example, Buch and Goldberg (2016), Frost et al.(2016), Ohls et al. (2016), and Damar and Mordel (2016).

${ }^{3}$ We define "international spillovers"as a situation when changes in macroprudential policies in the home country affect cross-border banking activities. For example, when there is an increase in domestic capital requirements imposed on domestic banks to curb home credit growth. The foreign bank branches,established locally, do not have to adhere to domestic capital requirments and home credit growth is only partially affected by the increase in domestic capital requirements.
} 
by looking at the impact of macroprudential policies of lending and borrowing countries during a period of rapid credit growth using aggregate data. Most study analyzes the impact of macroprudential policies using micro bank data and balance sheet characteristics of domestic banks. The objective is to evaluate if international lending activities of all international banks, without looking at an individual international bank, increases financial vulnerability due to the increase of lending and borrowing macroprudential policies. We measure financial vulnerability with the debt to service ratio of the non financial private sector borrowers- an early warning indicator considered to be our measure of financial vulnerability. ${ }^{4}$ Debt to service ratio captures better the burden of debt than other indicators such as credit-to-GDP ratio, (Drehamn and Juselius (2012)). The debt to service ratio has better signalling quality and it is a stable indicator compared to other measures used in the literature. Since macroprudential policies are implemented when the risks of crisis are rising, we analyse whether the response of cross-border credit depends on the financial environment of the countries involved in cross-border banking activities. The idea is to examine the extent to which changes in cross-border lending due to the implementation of prudential requirements depend on factors of financial vulnerability such as the increase of credit boom of both the lending and borrowing countries. ${ }^{5}$ We address the following questions concerning the effects of macroprudential policies at the the international level:

- Does excessive credit growth increase with international banking activities despite the implementation of prudential instruments in the lending and borrowing countries?

- Does the spillover effect of macroprudential policies depend on the financial conditions of the lending and borrowing countries?

An understanding of the dynamics of cross-border banking activities can help us identify if the international spillover of macroprudential policies is harmful to economy in maintaining a credit boom that policymakers are trying to dampen. It also helps identify if coordination or cooperation

\footnotetext{
${ }^{4}$ For example : Buch and Goldberg (2017) measure financial vulnerability with credit-GDP or output gap. Beirne and Friedrich (2017) consider financial vulnerability originating from the banking sector structure.

${ }^{5}$ In this dissertation, financial vulnerability is defined as the increase of credit boom measured by the increase of debt to service ratio.
} 
between countries involved in cross-border credit should be based on the financial conditions of the countries. The literature has focused on the role of the structure of the banking sector (see for example, Beirne and Friedrich (2017)), on banks balance sheets characteristics (see for example Avdjiev et al. (2017), and also on destination countries' macroprudential policies (see for example, Damar and Mordel (2016)) on the effectiveness of prudential tools. However, it is important to study the effectiveness of macroprudential policies at the aggregate level to understand the overall impact on bilateral credit of these policies and clarify the magnitude of leakage of international credit flows. One of our objectives is to understand if coordination of macroprudential policies across countries would be helpful increasing the effectiveness of macroprudential policies at curbing credit growth. ${ }^{6}$

The aim of policymakers is to reduce financial sector vulnerability in integrated banking markets despite the complexity of international banking activities. Therefore, questions regarding the relation between cross-border lending and macroprudential policies are important in terms of reducing banking sector failures induced by excessive banking risk taking by banks (Klomp and De Haan (2011)). ${ }^{7}$ Furthermore, credit plays an important role for economic growth as it is the source of funds for most investors and it supports the increase of trade in many countries. On the banking sector side, the main advantage of cross-border lending is related to bank risk diversification between domestic and foreign countries (Goetz et al., (2015)). Domestic banks can minimize the effect of domestic risk and problems related to domestic depositor panic by lending to borrowers from different countries (Allen et al., (2011)). The presence of foreign banks helps to create competition in domestic banking, which makes domestic banks more efficient. On the borrower's side, cross-border banking has diversification gains, such as the ability to smooth a credit constraint imposed by domestic banks, and also helps to reduce the cost of borrowing. Therefore, international banking activities are not only profitable but also influence the establishment of an efficient finan-

\footnotetext{
${ }^{6}$ See for example, Angelini et al. (2011) and De Paoli and Paustian (2013) on the interaction of monetary and macroprudential policies.

${ }^{7}$ Using a sample of 66 countries, Reinhart and Rogoff (2013) shows that in addition to the Great Depression which affected over $40 \%$ of countries in the 1930s, many countries (advanced, emerging and poor countries) experienced banking crises (regional, global) since the 1970s with the rise of international capital account liberalization. Over $30 \%$ of countries have experienced at least one banking crisis between 1970 and 2008.
} 
cial sector in different countries by increasing competition between banks, therefore it should be considered in the implementation of financial regulation.

Based on the most recent database of macroprudential policies developed by Cerutti et al. (2016), the usage of prudential tools is different across countries. Besides the fact that emerging countries have been using prudential tools more often than advanced economies, the choice of tools and the level and number of episodes of tightness in policy, are also different across countries. ${ }^{8}$ This study focuses on capital requirements and LTV ratio which are among the most used policies after the global financial crisis in our sample of countries. Since 2010, many countries increased capital requirements following the Basel III rule to reinforce banks resilience by imposing banks to hold a minimum of $4.5 \%$ of common equity of risk-weighted assets at all times (see BIS, 2010). In addition, Basel III imposes that the Tier1 Capital of banks must be at least $6.0 \%$ of risk weighted assets and the total capital must be at least $8 \%$ of risk-weighted assets (see BIS, 2010). The LTV ratios is a macroprudential tool mostly used in the housing sector to manage mortgage loans and has been adjusted mostly in emerging economies. A higher (lower) LTV ratio means that borrowers pledging their housing as a collateral would increase (decrease) the demand for credit. For example, home buyers facing, a high LTV ratio means that the down payment imposed by the banks is low, which allows home buyers to obtain higher mortgage loans. Except for capital requirements, there is no other policy that was increased across countries since 2010. Capital requirements were increased at least once in 30 out of 34 countries in our sample between 2000 and 2014. The LTV ratio changed in 15 out of 34 countries at least once during this time period.

For the analysis, we use a cross-sectional regression model to examine the impact of LTV ratios and capital requirements on bilateral cross-border bank claims. We control for some variables such as trade openess, the interest rate on loans, financial openness, and GDP growth of the lending and the borrowing countries. We focus on the relation between the macroprudential policies on bilateral cross-border bank claims. The results of our study are the following. First, we find that capital requirements are effective in reducing bilateral cross-border credit in most countries.

\footnotetext{
${ }^{8}$ See Table A.1 and A.2 in Appendix A.
} 
However, their effectiveness declines during a period of high credit boom in some lending and borrowing countries. The impact of LTV ratios differ depending on the group of destination or source countries we examine. Their impact is heterogeneous (we find different signs and levels of significance of LTV ratios) which may be explained by the fact that this policy is mainly used in the housing sector. Therefore, its impact depends on the extent to which borrowers in the housing sector of each group of countries loans from foreign banks. In general, the results are close to the findings in the literature, which focused on rapid credit growth leading to financial vulnerability originating from imbalances on banks balance sheets. This helps us to conclude that different types of financial vulnerabilities reduce the effectiveness of macroprudential policies at the international level.

This chapter is structured as follows. The next section presents a discussion of the relevant literature. Section 3 provides details about data, model specification, methodology and the regression results. Section 4 concludes the analysis.

\subsection{Literature Review}

The literature on the impact of macroprudential policies on international cross-border credit has been growing rapidly since the global financial crisis. There is a body of literature studying how macroprudential policies affect cross-border lending behavior of each individual country using micro-banking data. A few examples are the studies on the international impact of macroprudential policies on cross-border lending in Germany, Canada, the Netherlands, the USA, the UK, and Norway. ${ }^{9}$ Although the results are heterogeneous across countries the overall conclusion suggests that global banks headquartered in those countries have increased lending in countries with tighter prudential regulations. Buch and Goldberg (2016) provide a comprehensive understanding of the importance and the magnitude of the international prudential policies spillovers in selected advanced countries. They base their study on 15 countries with bank level data and use a meta

\footnotetext{
${ }^{9}$ See Ohls et al. (2016), Damar and Mordel (2016), Forst et al. (2016), Berrospide et al. (2016), Hills et al. (2016), Aiyar et al. (2014), and Getz Wold and Juelsrud (2016), respectively.
} 
analysis specification of papers studying the effectiveness of the macroprudential instruments at the international level. They find that there are heterogeneous effects of prudential policies on international lending growth. Factors such as differences of balance sheets characteristics (for example deposits shares), the periods of lending (whether the lending happens during stress periods or normal periods) can explain these mixed results. Overall, this literature demonstrates that macroprudential policies affect international bank lending and that the magnitude of this effect varies across countries. Unlike much of this literature, we analyze aggregate transmission channels of the prudential policies rather than at the bank level. In addition, we investigate the relation of international cross-border lending, macroprudential policies and financial vulnerability using a more precise early warning indicator, the debt to service ratio in a panel data analysis.

Another branch of the literature close to our research looks at how different channels of financial vulnerability, such as a credit boom or balance sheet imbalances at the bank level, affect the effectiveness of macroprudential policies. For example, Avdjiev et al. (2016) look at the reorientation of international lending due to the implementation of prudential tools in both source and destination countries. They analyze how different types of banks and the composition of their balance sheet characteristics influence the response of international credit. Using bilateral cross-border lending in an empirical framework, they find that if the LTV ratio and reserve requirements are tightened in the source country, small and better capitalized international banks with more liquid assets will increase international lending. Beirne and Friedrich (2017) examine the impact of macroprudential polices on capital flows using aggregate data and focus on banking sector characteristics to show how the structure of the banking sector is important and contributes to the effectiveness of prudential tools. They find that higher regulatory quality and higher creditto-deposit ratios increase the effectiveness of prudential tools in reducing international bank flows. In the same vein as Beirn and Friedrich (2017), Ghosh et al. (2014) analyze the impact of capital account restrictions on cross-border capital flows. They look at how both the source and the destination country prudential policies explain the adjustment of cross-border capital flows between countries. As in our analysis, they assess the extent to which coordination in establishing capital 
account restrictions is necessary to stabilize cross-border flows. Their results indicate that restrictions of capital flows from both the source and destination countries result in a greater reduction of the flows compared to when only one country restricts capital flows. They observe that there exists spillover effects with capital going toward countries with more relaxed restrictions. They find that cooperative restrictions of the source and destination countries is necessary to increase the performance of macroprudential policies by managing cross-country flows. Unlike this literature, we analyze the impact of the policies on international credit growth rather capital flows. In addition, we examine if the effectiveness of prudential policies of source and destination countries depend on the financial cycles of these countries. We seek to understand the role of both countries' prudential tools in mitigating financial vulnerability during a period of credit boom.

Other related literature examines financial regulations driving cross border lending and the role of financial authorities intervention to influence international credit management without considering credit boom and bust periods. In that context, Bremus and Fratzscher (2015) identify how the drivers of bilateral cross-border banking have changed since the global financial crisis. The financial regulation policies used are capital regulatory policies, bank capital regulation, official supervision power and the overall independence of banking supervisory authorities. Their results were significant in showing that the increase of source country financial regulatory policies in the form of capital regulation explains why some countries - particularly Euro area countries - have withdrawn from foreign lending in favor of domestic lending as the increase in the capital to asset ratio reduces funds available for credit supply and makes cross-border credit expensive. In contrast, the increase in supervisory power or supervisory independence expanded cross-border lending because in this case banks have the ability to lend domestically or internationally without the influence of the government which usually promotes domestic lending.

Reinhardt and Sowebutts (2016) empirically investigate the impact of tightening and loosening different types of macroprudential policies on international borrowing in sixty countries from 1999 to 2014. They group macroprudential policies in three different categories: lending policies (LTV ratio, debt service ratio and repayment periods), reserve requirements and capital regulation 
policies (risk weight changes and capital requirement changes). The authors explore, separately, how each type of policy influences international borrowing when tightened and loosened. The objective of their paper is to examine the source the influence of financial regulations on international banking flows. They find that capital requirement policies on home banks and foreign subsidiaries rather than foreign bank branches are the drivers of the increase of foreign borrowing by international banks. They find that if a country experiences an increase of domestic capital requirements, foreign banks increase lending to that country's non-bank sector. They do not find evidence of lending standards and reserve requirements significantly affecting the changes of bilateral crossborder lending. Using different types of macroprudential policies from Reinhardt and Sowerbutts (2016), Houston et al. (2012) conduct a similar analysis. They consider 26 source countries to 120 recipients countries of foreign lending to see how these flows are influenced by differences in bank regulations from 1999 to 2009 . They find that high restrictions on financial regulation policies increase foreign lending through the creation of subsidiaries and branches in countries with less restricted policies.

Figuet et al. (2015) focus on the ex-ante impact of Tier 1 ratio and leverage ratio macroprudential regulatory policies on foreign claims in thirty emerging countries from 1999 to 2010 and determine ex-ante the impact of these regulatory policies on cross-border bank lending to emerging countries. Contrary to the results of Bremus and Fratzscher (2015), which show that cross-border claims from advanced economies toward emerging economies did not change with the increase of financial regulation, Figuet et al. (2015) find that macroprudential policies decreased cross-border borrowing by emerging economies by $19.08 \%$. With these differences in the literature, we believe that it is crucial to clarify the international effect of macroprudential policies in order to identify effective coordination measures across countries.

Beck et al. (2012) address the issues of failing cross-border banking activities in European countries during the recent global financial crisis. They demonstrate that the gain from the intervention of national authorities to support failing banks differs across countries and depends on the variety of cross-border banking activities that these countries are involved in. They categorize 
cross-border bank activities in three different dimensions: equity, deposit and asset dimensions of cross-border bank activities which vary in most European countries. Their empirical and theoretical results show that the willingness of financial authorities to intervene in international regulation decisions increases with the share of foreign equity of the country and decreases with the share of foreign deposits and assets of the country.

In the same context of international coordination, Dell'Ariccia (2006) demonstrates the benefits and costs of regulatory union in financially integrated jurisdictions. The author finds that symmetric countries have more benefits to form global regulationss than asymmetric countries . In fact, coordinated policies would mean that asymmetric countries lose to some extent the ability to modify policies when they need to address country specific issues whereas symmetric countries would need to make any policy adjustment at the same time. Credit competition among lenders increases the incentive of national regulators to reduce capital requirements since they reduce bank profits.

Faia and Mauro (2016) analyze the impact of cooperation of financial regimes between financial authorities across countries on resolving banking sector failures: SPE (Single Point of Entry) versus MPE (Multiple Points of Entry). ${ }^{10}$ Using a game theoretic framework, they find that both SPE and MPE reduce welfare. In fact, each regime tends to protect domestic investors (both bond holders and equity holders) and fails to take into account cross-country bond and equity market investment. According to their study, it is profitable for the economy to adopt a MPE when the banking sector is decentralized.

We analyze how to solve the issues related to avoidance of the policies by looking at how financial regulatory policies influence bilateral cross-border lending. However, we differentiate our analysis by focusing on particular financial regulation tools, the macroprudential policies based on the financial cycles of lending and borrowing countries at the international level using aggregate data. In addition, we use a recent macroprudential policies database not explored by the literature.

\footnotetext{
${ }^{10} \mathrm{SPE}$ is the case where only one domestic financial authority has the ability to make decisions related to resolving banking sector issues.

MPE is the case where multiple financial authorities have ability to make decisions related to resolving banking sector issues.
} 
It is relevant to investigate the impact of other policies as countries involved in cross-border banking activities have implemented more prudential tools since the global financial crisis. We also analyze whether the source of avoidance may differ for emerging countries, advanced countries and Eurozone countries which has not been considered.

\subsection{Empirical analysis and methodology}

We test the importance of the relation between cross-border lending and the interaction of a financial vulnerability measure with macroprudential policies in the source (lending) and destination (borrowing) countries using bilateral aggregate cross-border banking data.

\subsubsection{Data description}

\section{Dependent variable}

We obtained data on bilateral aggregate cross-border banking claims of 15 reporting advanced economies to 34 recipient economies from the BIS consolidated banking statistics. ${ }^{11}$ The data is available at the quarterly frequency from 2000 to 2014, which we transform to the annual frequency because the majority of the control variables we use are only available at the annual frequency. The sample choice is based on the availability of the data and the usage of macroprudential policies in both the lending and borrowing countries. We omit countries with no or incomplete data on crossborder lending, even if they have implemented macroprudential policies. Therefore, we use only advanced countries as the lending countries. We use the immediate borrower data of consolidated banking statistics of total claims from all banks (domestic and multinational banks) to borrowing countries. The aggregate foreign lending variable is the sum of all bilateral cross-border lending claims from reporting to the borrowing country. The dependent variable is defined as the change in the logarithm of bilateral cross-border banking claims from time $t$ to time $t-1$.

\footnotetext{
${ }^{11}$ See the list of lending countries in Appendix A -Table A.3 and the list of borrowing countries in Appendix A -Table A.4.
} 


\section{Macroprudential policies}

We use the quarterly macroprudential data from Cerutti, Claessens and Laeven (2016) transformed into an annual index for each prudential tool by summing up the changes in their usage that occurred in each quarter. The macroprudential policies are dummies, equal to 1 when the country tightens the policy, equal to zero when no change was observed for a specific policy and equal to -1 when the instrument was relaxed in a specific quarter. To build the database, the authors collected information about the policy changes from central banks, national authorities in each country and from IMF surveys such as Lim et al. (2011), Kuttner and Shim (2013), Akinci and Olmstead-Romsey (2015). In countries with incomplete information on any instruments, we give a value of zero which implies that there was no change of the policy. This database covers a wider set of instruments compared to other macroprudential data sets such as the database used in Ostry et. (2012), Lim et al. (2010), and Reinhart and Sowerbutts (2015). Table A.1 and A.2 present selected prudential policies. ${ }^{12}$ We choose the two most commonly used policies in this database and analyze their impact on international bank lending. ${ }^{13}$ We use the general capital requirements capturing all the regulatory changes based on the Basel III ccords, which urged banks to increase their capital requirements. We analyze LTV ratio caps used to limit credit on mortgage loans to borrowers. The changes of LTV ratios are the variation of LTV ratio limits that affect real estate transactions taking into account the changes of the maximum amount insured in real estate transactions. It takes time for a prudential policy to become effective (Drehmann and Juselius, 2013), thus we also consider one lagged value of the prudential policy index, in our regression model, to analyze their impact on international bank lending. Most of the policy changes involved a tightening in the period around and after the financial crash. This can be explained by the fact that capital requirements change with the recommendations of Basel agreement reforms. The most recent reforms which required banks to increase the requirements on risky weight assets started in 2010 .

\footnotetext{
${ }^{12}$ We observe that macroprudential policies did not change a lot over the years. This is mainly because macroprudential policies do not target short term risk, thus their change is usually rare once implemented (Claessness et al. (2015)).

${ }^{13}$ The choice is based on the frequent usage of the policies in our country-sample.
} 
In addition, following the global financial crisis, many countries adopted expansionary monetary policies. Thus, to reduce the risk taking by borrowers the LTV ratios were tightened.

\section{Financial vulnerability}

We use the debt to service ratio as our measure of financial conditions. The debt to service ratio is defined as the sum of both interest payment and debt repayment over the income of the borrower (Drehman and Juselius (2012)). As in Drehman and Juselius (2013), we measure the debt to service ratio with data on total credit to the private non-financial sector from the BIS database. This

measure differs from the credit variable as it considers total credit to the private sector without distinguishing the source of credit. It also differs from other early warning indicators as it considers factors such as changes in interest rates and maturities of loans which affect the borrowers repayment capacity. For example, the credit-to-GDP ratio (used in many studies as a measure of financial conditions) considers that interest rates and maturities are constant overtime, which shows that this indicator may not measure correctly the ability of the private non financial sector to repay debt. Drehmann and Juselius (2013) demonstrate that the debt to service ratio's performance, its signaling quality (timing with respect to crisis dating) and its stability across countries, is better than other commonly used financial indicators such as the credit to GDP ratio, credit growth, non core deposit ratio, property price gap, property price growth, GDP growth, equity price gap, equity price growth, or history. Figure 2.2 presents the evolution of the debt to service ratio for our sample of advanced and emerging countries. We observe that debt to service ratio was increasing from 2006 up to 2008 in advanced economies, which corresponds to the period preceding the recent global financial crisis and demonstrate the right timing signal's of the indicator. This indicates that a high debt to service ratio signals a rise in the risk of a banking crisis. In fact an increasing debt to service ratio over a period of time increases the probability of crisis and credit default if borrowers experience a shortfall in income. The debt to service ratio also increased in emerging countries between 2006 and 2009 but at a lower rate compared to advanced countries. This is due to the difference of country-specific factors such as income differences between advanced and emerging 
countries and credit availability in the two groups of countries.

Figure 2.2: Debt service ratio 2000-2014

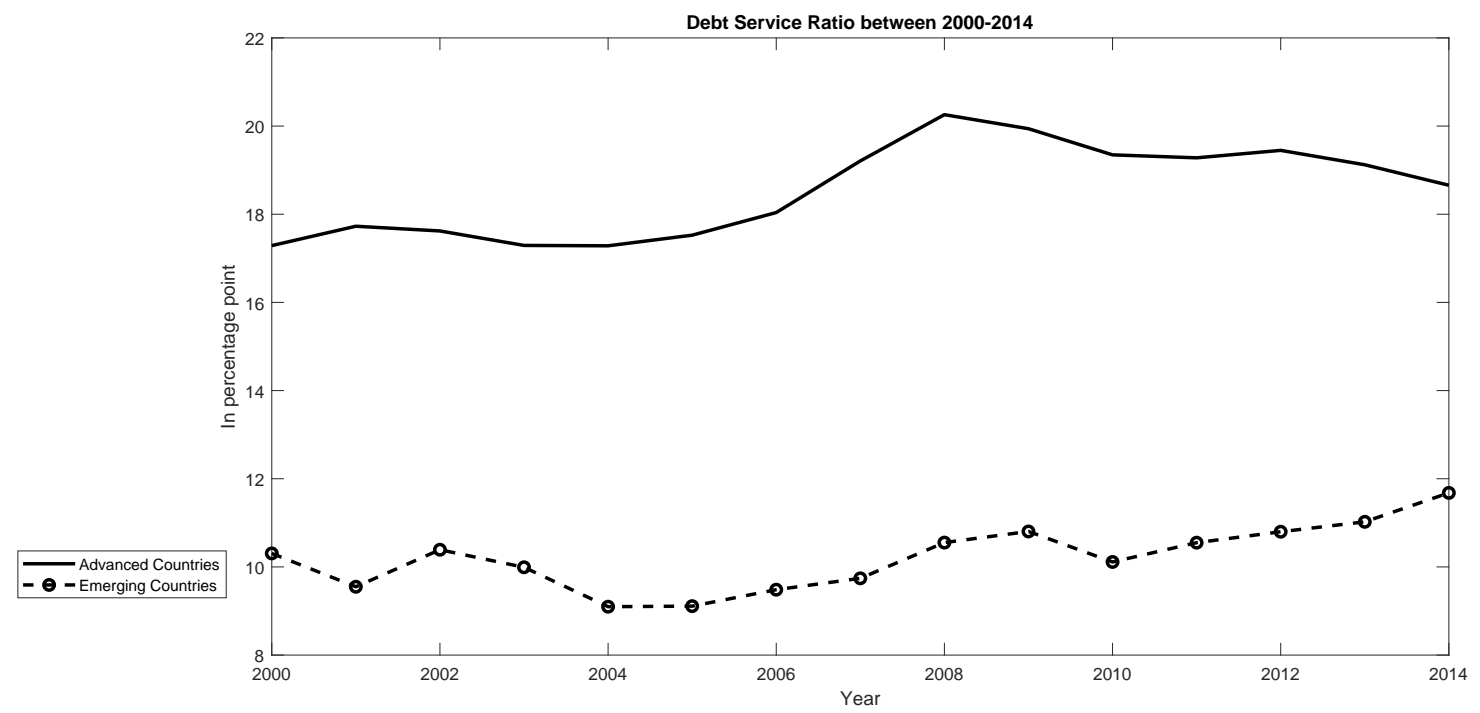

Data source : BIS- Debt Service Ratio (2000-2014).The borrowers are the private non-financial sector. The sample size is composed by 34 borrowing countries.

\section{Control variables}

We include control variables influencing changes of bilateral cross-border lending. The control variables considered help us to take into consideration factors related to the banking structure, financial and economic development of the source and destination countries. Variables such as real GDP growth, trade openness, financial openness, and the interest rate on long term loans in source and destination countries are considered. Data on real GDP growth is collected from the World Bank database (WDI database). Trade openness is constructed as the ratio of the sum of imports (in current USD) and exports (in current USD) over the real GDP (in current USD) using data extracted from World Bank-WDI database. We use the interest rate on long term loans as a measure of the lending interest rate. This was obtained from from the IMF database. All control variables are expressed as the change in the logarithm. 


\subsubsection{Model specification}

The cross-sectional regression model is defined as follows ${ }^{14}$ :

$$
\triangle \ln \left(C_{s, d, t}\right)=\beta_{0}+\sum_{j=0}^{1} \alpha_{j}^{d} M_{t-j}^{d}+\sum_{j=0}^{1} \alpha_{j}^{s} M_{t-j}^{s}+\gamma^{d} X_{t-1}^{d}+\gamma^{s} X_{t-1}^{s}+f_{c}+f_{t}+\varepsilon_{s, d, t}
$$

where subscripts $s$ and $d$ represent the source and destination countries respectively. $\triangle \ln C_{s, d, t}$ denotes the change of bilateral cross-border credit received by each country $d$ from country $s$ between periods $t-1$ and $t . M^{d}\left(M^{s}\right)$ denotes the macroprudential policy formulated as dummy variables (mentioned in Section 2.3.1 above) used in country $d(s) . X_{t-1}^{s}\left(X_{t-1}^{d}\right)$ is a vector of control variables which includes each country's GDP growth, trade openness, financial openness and loan interest rate. All the control variables are defined as log change of the variable from $t-1$ to time $t . f_{c}$ is the country's fixed effects and $f_{t}$ is the time fixed effects. $\varepsilon_{s, d, t}$ is the error term. Prudential policies are implemented to mitigate credit growth. Therefore, we expect the sign of $\alpha^{s}$ and $\alpha^{d}$ to be negative and statistically significant if the prudential policies implemented in lending and borrowing countries are effective in reducing international credit growth in the interacting countries. We include one lag of our macroprudential policy variables because the effect of changes in macroprudential policy can take a some time to affect credit growth.

In this first regression, we regress bilateral cross-border credit first on capital requirements and then on the LTV ratio. In each case we estimate the extent to which countries are likely to engage in cross-border lending if their countries' macroprudential policies are changed. Since macroprudential policies have changed differently in advanced and emerging countries, we run separete regressions for each of these groups of countries. The destination countries are divided in three groups: emerging countries, eurozone countries and advanced non-eurozone countries. The source countries are divided in two groups: advanced non-eurozone countries and eurozone countries. The coefficients of interest are $\alpha^{s}$ and $\alpha^{d}$. We focus on the cumulative effect of macroprudential

\footnotetext{
${ }^{14} \mathrm{~A}$ logarithmic model allows us to evaluate how the change of macroprudential policies influence the growth of international lending.
} 
policies (see equations (2.2) and (2.3) below) from source and destination countries.

$$
\begin{aligned}
& \frac{\partial \triangle \ln \left(C_{s, d, t}\right)}{\partial M_{t-j}^{d}}=\sum_{j=0}^{1} \alpha_{j}^{d} \\
& \frac{\partial \triangle \ln \left(C_{s, d, t}\right)}{\partial M_{t-j}^{s}}=\sum_{j=0}^{1} \alpha_{j}^{s}
\end{aligned}
$$

We also explore if the impact of macroprudential policies depends on the financial state of the source and destination countries. In the second regression specification we introduce a new variable measuring the interaction between each macroprudential instrument and the financial vulnerability variable (the debt to service ratio) for the source and the destination countries.

$$
\begin{gathered}
\triangle \ln \left(C_{s, d, t}\right)=\beta_{0}+\sum_{j=0}^{1} \beta_{j}^{s} \triangle \ln \left(F_{t-j}^{s}\right) * M_{t-j}^{s}+\sum_{j=0}^{1} \beta_{j}^{d} \triangle \ln \left(F_{t-j}^{d}\right) * M_{t-j}^{d} \\
+\sum_{j=0}^{1} \alpha_{j}^{d} M_{t-j}^{d}+\sum_{j=0}^{1} \alpha_{j}^{s} M_{t-j}^{s}+\gamma^{d} X_{t-1}^{d}+\gamma^{s} X_{t-1}^{s}+f_{c}+f_{t}+\varepsilon_{s, d, t}
\end{gathered}
$$

The signs of $\beta^{s}$ and $\beta^{d}$ are expected to be negative, if the macroprudential policies are effective in times of financial vulnerability in the source and destination countries, respectively. As in the previous regression, we focus on the cumulative effect of the macroprudential policies (equations (2.2) and (2.3) ) and the cumulative effect considering the role the factor of financial vulnerability (see equations (2.5) and (2.6)) but also the interaction variable between macroprudential policy and debt service ratio $\left(\sum_{j=0}^{1} \beta_{j}^{s}\right.$ and $\left.\sum_{j=0}^{1} \beta_{j}^{d}\right)$ to understand the importance of financial cycles on the performance of macroprudential policies. ${ }^{15}$

$$
\frac{\partial \triangle \ln \left(C_{s, d, t}\right)}{\partial M_{t-j}^{d}}=\sum_{j=0}^{1} \beta_{j}^{d} \triangle \ln \left(F_{t-j}^{d}\right)+\sum_{j=0}^{1} \alpha_{j}^{d}
$$

\footnotetext{
${ }^{15}$ The estimated cumulative coefficient is the marginal effect of the macroprudential policies on credit when there is a change in financial vulnerability measured by the change in the debt to service ratio.
} 


$$
\frac{\partial \triangle \ln \left(C_{s, d, t}\right)}{\partial M_{t-j}^{s}}=\sum_{j=0}^{1} \beta_{j}^{s} \triangle \ln \left(F_{t-j}^{s}\right)+\sum_{j=0}^{1} \alpha_{j}^{s}
$$

\subsubsection{Regression results}

We analyze the impact of macroprudential policieson the change in bilateral cross-border credit between borrowing countries (both emerging and advanced economies) and in lending countries (advanced economies). ${ }^{16}$ In the two sub-sections below we discuss the estimation results when capital requirements and LTV ratios are the macroprudential policies, respectively. In Appendix B, we present more estimation results, where advanced countries are divided in two groups: advanced non eurozone countries and eurozone countries. In all of our tables, the column labeled Specification (1) refers to estimating equation (2.1). The first two rows report estimates of the sums in equations (2.2) and (2.3) with the standard error in parenthesis. These sums are the marginal effect of policy on bilateral credit growth. The column labeled Specification (2) refers to estimating equation (2.4). The first two rows report estimates of the sums in equations (2.2) and (2.3) with the standard error in parenthesis. In rows three and four we report estimates of the sums of the coefficients on the interaction financial vulnerability variable with the macroprudential policy variable. The estimated standard error is in parenthesis. In rows five and six we report estimates of the sums of the marginal effect of policy on bilateral credit growth in equations (2.5) and (2.6) with the standard error in parenthesis. In the first column we label the latter "Cum. effect (i)" for destination countries and "Cum. effect $(\mathrm{j})$ " for source countries. ${ }^{17}$

\footnotetext{
${ }^{16}$ Emerging countries are excluded in the group of lending countries because data on international lending from emerging countries is very limited and incomplete.

${ }^{17}$ An IV estimation using lagged values of macroprudential policies gives similar results.
} 


\subsubsection{Capital requirements}

In Table 2.2, Specification (1) reports the estimated coefficients showing the impact of a change in capital requirements in both destination (borrowing) and source (lending) countries on the change of bilateral cross-border credit. In row 1, the sum of the coefficients on the effect of a change in capital requirements in the destination countries are both negative and statistically significant at the $1 \%$ level and 5\% level for emerging and advanced group of countries, respectively. Thus an increase in capital requirements in both emerging and advanced countries reduces bilateral international bank credit from all advanced countries. One might have thought that this policy would curb domestic bank lending in emerging countries and cause a positive effect on borrowing from banks in advanced countries. The correlation of changes in capital requirements between source and destination pairs of advanced countries is $34 \%$. Thus an increase in capital requirements in either source or destination countries might signal a general tightening of credit and expain the negative coefficents.

Dividing advanced destination countries into two categories (advanced non-eurozone and eurozone countries) gives similar results (see Appendix B). In Table B.1 (source countries are advanced non-eurozone) and Table B.5 (source countries are eurozone countries), the coefficients of the effect of a change in capital requirements in destination and source countries are both negative and statistically significant at the $1 \%$ level for all three groups of countries (emerging, advanced non-eurozone and eurozone countries). Overall, our findings imply that an increase in capital requirements is effective in mitigating credit growth.

In Specification (2) cumulative, we include the interaction of capital requirements with the variable reflecting the financial vulnerability of the economy, as measured by a high debt service ratio. We focus the sum of the coefficients on the interaction term and the marginal effect of policy changes (rows 3 to 6 in Table 2.2 - Specification (2)). About half of the estimated sums of coefficients are negative and significant and the other coefficents are statistically no different than zero. In most cases, we observe that the coefficients values of the interaction terms are of a small magnitude in Specification (2) compared to the coefficients values of the macroprudential policies. 
Table 2.2: Effects of capital requirements on bilateral cross-border credit from advanced countries

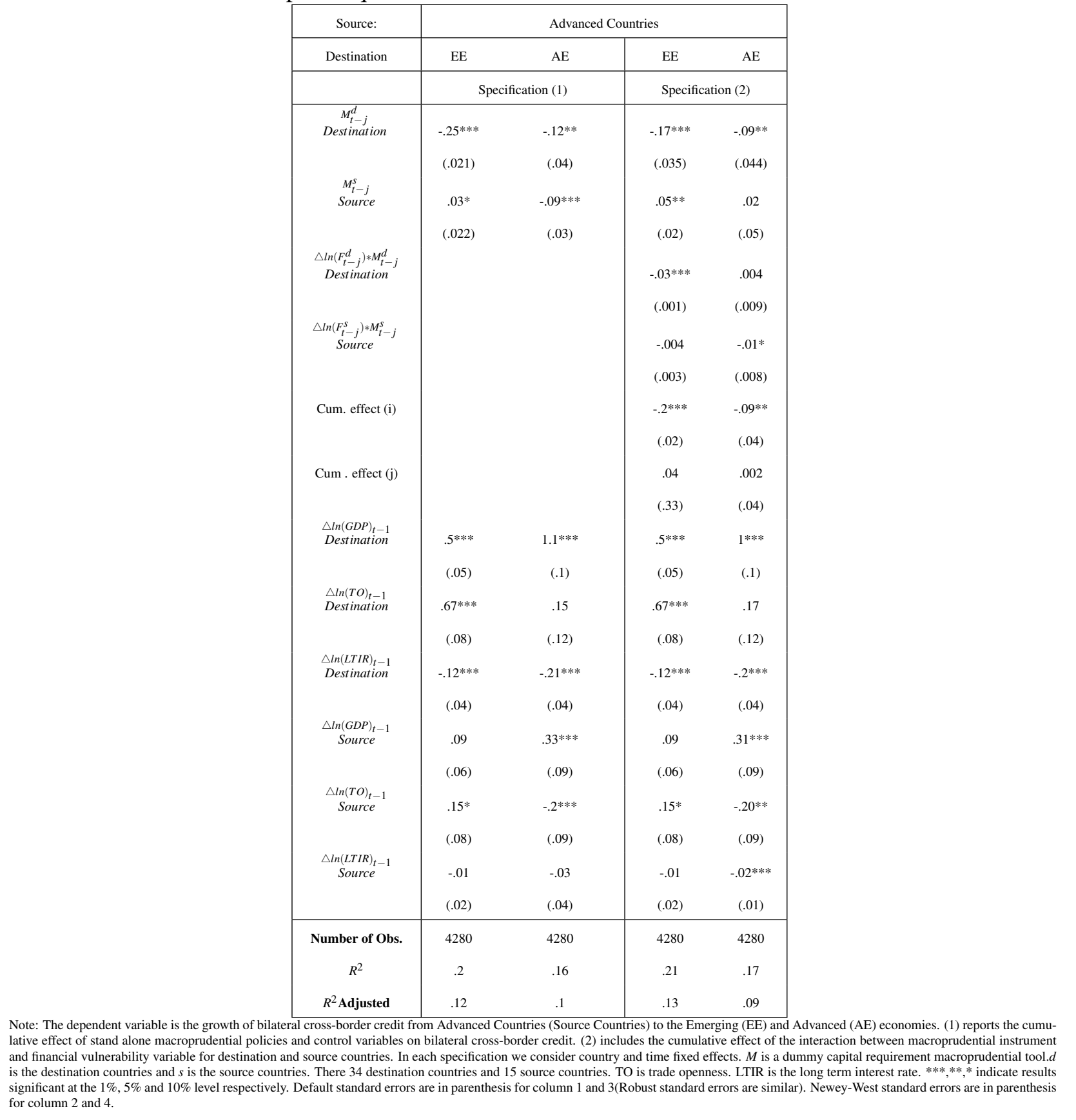

This lends modest support to the notion that increases in capital requirements in a period of financial vulnerability dampens modestly international bank lending. In addition, we perform the Wooldridge test for autocorrelation on the data and find that there might be autocorrelation issues; particularly in column 2 and 4 when advanced countries are lending to other advanced economies. We correct this issue by using the Newey-West estimator and the estimated variables are reported 
in Table 2.2- column 2 and 4.

For destination countries, we find that growth in GDP and trade openness have a positive and significant effect on international bank lending, presumably because it increases the demand for credit. We find that changes in the long term interest rate have a negative effect on international bank lending, presumably because it reduces the demand for credit. For source countries the estimated coefficients have mixed signs of the effect of the growth in GDP and trade openness on international bank lending with most coefficients being statistically significant. We find that changes in the long term interest rate in the source country have a negative but statistically insignificant effect on international bank lending. Dividing advanced destination countries into two categories (advanced non-eurozone and eurozone countries) produces similar results (see Tables B.1 and B.5 in Appendix B).

\subsubsection{LTV ratio}

In Table 2.3, we report the impact of a change in the LTV ratio on bilateral credit originating from advanced countries. In Specification (1) we report the sum of the two coefficients (equations (2.2) and (2.3)) on the LTV ratio (for destination and source countries). Overall, we note that the estimated coefficients are statistically insignificant and of smaller magnitude compared to the estimated coefficients when we use capital requirements in our index of macroprudential policy. This may be due to the fact that the LTV ratio did not change in all countries, whereas capital requirements increased in all countries considered after the 2007 financial crisis. As we reported in Table A.1 emerging countries have tightened LTV ratios at least 27 times between 2000 and 2014, whereas advanced countries tightened the policies only 15 times. These findings can also be explained by the fact that LTV ratios are considered to be sector specific macroprudential policies often used in the housing sector. Thus, if in some destination countries, the housing sector is not the only sector involved in international credit, changing LTV ratio may not reduce international credit or may not have a statistically significant effect on international credit. The results are similar when we divide lending countries into advanced non eurozone and eurozone countries (see 
Appendix B Table B.2 and Table B.6 Specification (1)).

Table 2.3: Effects of the LTV ratio on bilateral cross-border credit from advanced countries

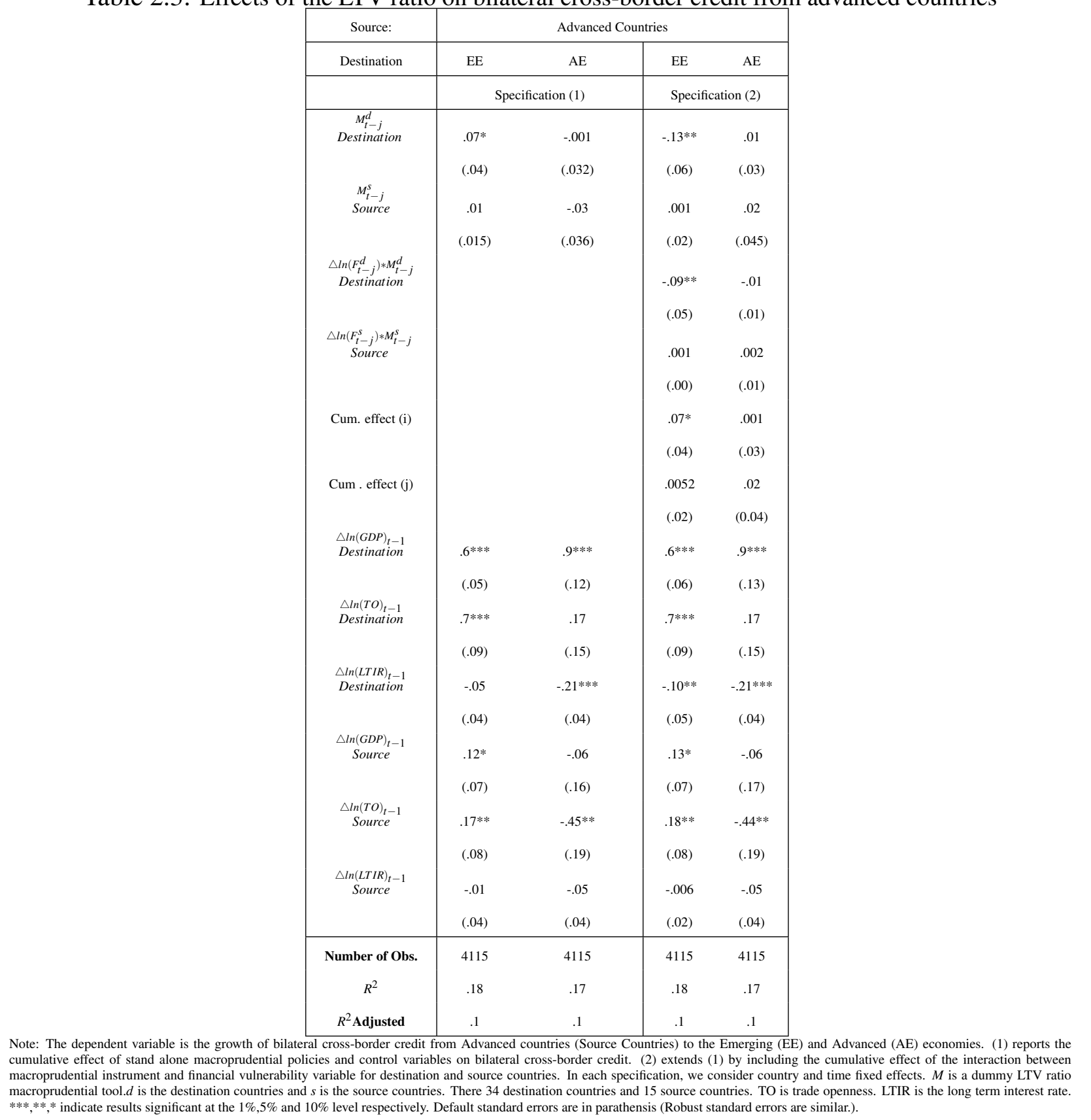

In Specification (2), we include the interaction variable between LTV ratios and the financial vulnerability measure. Our results are similar to Specification (1). Most estimated sums of coefficients are statistically insignificant, except in the case where eurozone countries lend to other eurozone countries (see Appendix B Table B.6 Specification (2)). In this case the marginal effect 
of tightening LTV ratios in destination countries on the change in bilateral credit is negative and statistically significant at the $1 \%$ level. This is a similar effect as tightening of captial requirements in the case where eurozone countries lend to other eurozone countries.

\subsection{Robustness check}

The usage of dummy variables has limitations since it does not tell us the exact size of change for each macroprudential policy. In this section, we examine if other measures of macroprudential policies lead to different results. Thus, following Angelini et al. (2011), we use the capital to asset ratio as an alternative measure of capital requirements. The data on the capital to asset ratio is from World Bank - WDI database. The ratio of household loans over the price of housing is the alternative measurement of the LTV ratio. We use their growth rates as measures for the two policies. ${ }^{18}$ Jacome and Mitra (2015) show that Asian countries have been using this measurement to calculate the LTV ratio. The ratio is constructed using the total household credit and the real housing price data retrieved from BIS database.

\subsubsection{Alternative measure for capital requirements}

In rows 1 and 2 of specification (1) of Table 2.4, we report the sum of two estimated coefficients on the alternative measure capital requirements in the destination and source countries. We find that all estimated coefficients for the destination and source group of countries have a negative sign but only one is statistically significant. Dividing advanced destination countries into two categories (advanced non-eurozone and eurozone countries) gives much more statistically significant results (see Appendix B). In Table B.3 (source countries are advanced non-eurozone) and Table B.7 (source countries are eurozone countries), the coefficients of the cumulative effect of a change in the capital to asset ratio in destination and source countries are both negative and statistically

\footnotetext{
${ }^{18}$ This measure is different from how the dummy variable was constructed in Cerutti et al. (2016). The dummy variable takes into account the changes related to the maximum amount insured in real estate transactions and the changes in LTV regulations related to the maximum LTV allowed in covered bonds (Denmark and Finland) not used by the alternative measure of LTV ratio.
} 
significant at the $1 \%$ level for most of three groups of borrowing countries (emerging, advanced non-eurozone and eurozone countries). Overall, the results are similar to results in Table 2.2 that is discussed in Section 2.3.3.1 above and confirm that an increase of capital requirements reduces international bank lending.

Table 2.4: Effects of capital to asset ratio on bilateral cross-border credit from Advanced countries

\begin{tabular}{|c|c|c|c|c|}
\hline Source: & \multicolumn{4}{|c|}{ Advanced Countries } \\
\hline \multirow[t]{2}{*}{ Destination } & $\mathrm{EE}$ & $\mathrm{AE}$ & $\mathrm{EE}$ & $\mathrm{AE}$ \\
\hline & \multicolumn{2}{|c|}{ Specification (1) } & \multicolumn{2}{|c|}{ Specification (2) } \\
\hline $\begin{array}{c}M_{t-j}^{d} \\
\text { Destination }\end{array}$ & $-.3^{* *}$ & -.1 & $-.3 *$ & -.17 \\
\hline & (.13) & (.11) & (.17) & (.12) \\
\hline$M_{t-j}^{s}$ & & & & \\
\hline Source & -.06 & .04 & -.06 & .16 \\
\hline & $(.045)$ & $(.12)$ & $(.05)$ & (.14) \\
\hline \multirow[t]{2}{*}{$\begin{array}{c}\Delta \ln \left(F_{t-j}^{d}\right) * M_{t-j}^{d} \\
\text { Destination }\end{array}$} & & & -.003 & $.05^{* *}$ \\
\hline & & & (.03) & $(.02)$ \\
\hline \multirow[t]{2}{*}{$\begin{array}{c}\Delta \ln \left(F_{t-j}^{S}\right) * M_{t-j}^{S} \\
\quad \text { Source }\end{array}$} & & & -.0002 & $.04 * *$ \\
\hline & & & $(.01)$ & $(0.02)$ \\
\hline \multirow[t]{2}{*}{ Cum. effect (i) } & & & $-.3 *$ & $-.03 *$ \\
\hline & & & $(.15)$ & $(.02)$ \\
\hline \multirow[t]{2}{*}{ Cum . effect (j) } & & & -.06 & -.11 \\
\hline & & & $(.05)$ & $(.12)$ \\
\hline \multirow[t]{2}{*}{$\begin{array}{l}\triangle \ln (G D P)_{t-1} \\
\text { Destination }\end{array}$} & $.14^{* *}$ & $.68^{* * *}$ & $.15^{* * *}$ & $.7 * * *$ \\
\hline & $(.06)$ & $(.15)$ & (.1) & $(.15)$ \\
\hline \multirow[t]{2}{*}{$\begin{array}{l}\triangle \ln (T O)_{t-1} \\
\text { Destination }\end{array}$} & -.02 & .1 & -.05 & .11 \\
\hline & $(.09)$ & (.15) & $(.11)$ & (.16) \\
\hline \multirow[t]{2}{*}{$\begin{array}{l}\Delta \ln (\text { LTIR })_{t-1} \\
\text { Destination }\end{array}$} & -.05 & $-.15^{* * * *}$ & -.03 & $-.17 * * *$ \\
\hline & $(.05)$ & $(.04)$ & $(.05)$ & $(.04)$ \\
\hline \multirow[t]{2}{*}{$\begin{array}{c}\triangle \ln (G D P)_{t-1} \\
\quad \text { Source }\end{array}$} & $.12 *$ & -.18 & $.13^{* *}$ & -.14 \\
\hline & $(.07)$ & (.19) & (.07) & (.19) \\
\hline \multirow[t]{2}{*}{$\begin{array}{l}\Delta \ln (T O)_{t-1} \\
\text { Source }\end{array}$} & $.16^{* *}$ & $-.41 *$ & $.16^{* *}$ & $-.4^{*}$ \\
\hline & $(.08)$ & $(.22)$ & (.08) & $(.22)$ \\
\hline \multirow[t]{2}{*}{$\begin{array}{l}\triangle \ln (\text { LTIR })_{t-1} \\
\quad \text { Source }\end{array}$} & -.02 & -.03 & -.02 & -.004 \\
\hline & $(.02)$ & (.04) & $(.02)$ & $(.04)$ \\
\hline Number of Obs. & 2763 & 2763 & 2763 & 2763 \\
\hline$R^{2}$ & .21 & .17 & .21 & .17 \\
\hline$R^{2}$ Adjusted & .1 & .05 & .1 & .05 \\
\hline
\end{tabular}

Note: The dependent variable is the growth of bilateral cross-border credit from Advanced countries (Source Countries) to the Emerging (EE) and Advanced (AE) economies. (1) reports the cumulative effect of stand alone macroprudential policies and control variables on bilateral cross-border credit. (2) extends (1) by including the cumulative effect of the interaction between macroprudential instrument and financial vulnerability variable for destination and source countries. In each specification, we consider country and time fixed effects. $M$ is capital to asset ratio macroprudential tool. $d$ is the destination countries and $s$ is the source countries. There 34 destination countries and 15 source countries. TO is trade openness. LTIR is the long term interest rate. ***,**** indicate results significant at the $1 \%, 5 \%$ and $10 \%$ level respectively. Default standard errors are in parathensis (Robust standard errors are similar.).

In Specification (2), row 5 and 6 present the estimated cumulative effects of the capital to asset 
ratio on international bank lending in times of high financial vulnerability (see Table 2.4 and Tables B.3 and B.7 in Appendix B). In the case where eurozone countries lend to other eurozone countries the marginal effect of tightening capital to asset ratio on the change in bilateral credit is negative and statistically significant at the $1 \%$ level. When other advanced countries are added to the group of lenders the results are mixed.

\subsubsection{Alternative measure for LTV ratio}

Table 2.5 presents the estimation results obtained using an alternative measurement of the LTV ratio; the ratio of the household loan to the price of housing. The interpretation of the LTV ratio constructed with these data is different from the interpretation of the dummy variable. In this section, an increase of the LTV ratio means that there is a relaxation of the policy, whereas in Table 2.3, an increase of a dummy LTV ratio means that there is tightness of the policy. Thus, with a high LTV ratio, borrowers have the ability to increase credit.

In Specification (1), the sum of the coefficients on the alternative LTV ratio in destination countries are estimated to be negative and statistically significant. If the LTV ratios are high, it implies that borrowers in destination countries can increase borrowing from domestic banks and this might explain the reduction of international credit growth. On the other hand, the sum of the coefficients on the alternative LTV ratio in source countries are estimated to be positive and statistically significant when advanced countries are the destination group. This might signal a relaxation of macroprudential policy among all advanced eocnomies. We find similar results when we break the advanced country lenders into advanced non eurozone and eurozone country groups (see Appendix Table B.4 and Table B.8 respectively). We also find similar results in Specification (2).We observe that in times of high financial vulneability, the LTV ratio has a significant impact on borrowing countries. In Specification (2) - row 5, the sign of the coefficients are negative and significant . A credit boom in the destination countries amplifies the demand for credit. 
Table 2.5: Effects of LTV Ratio on bilateral cross-border credit from advanced countries

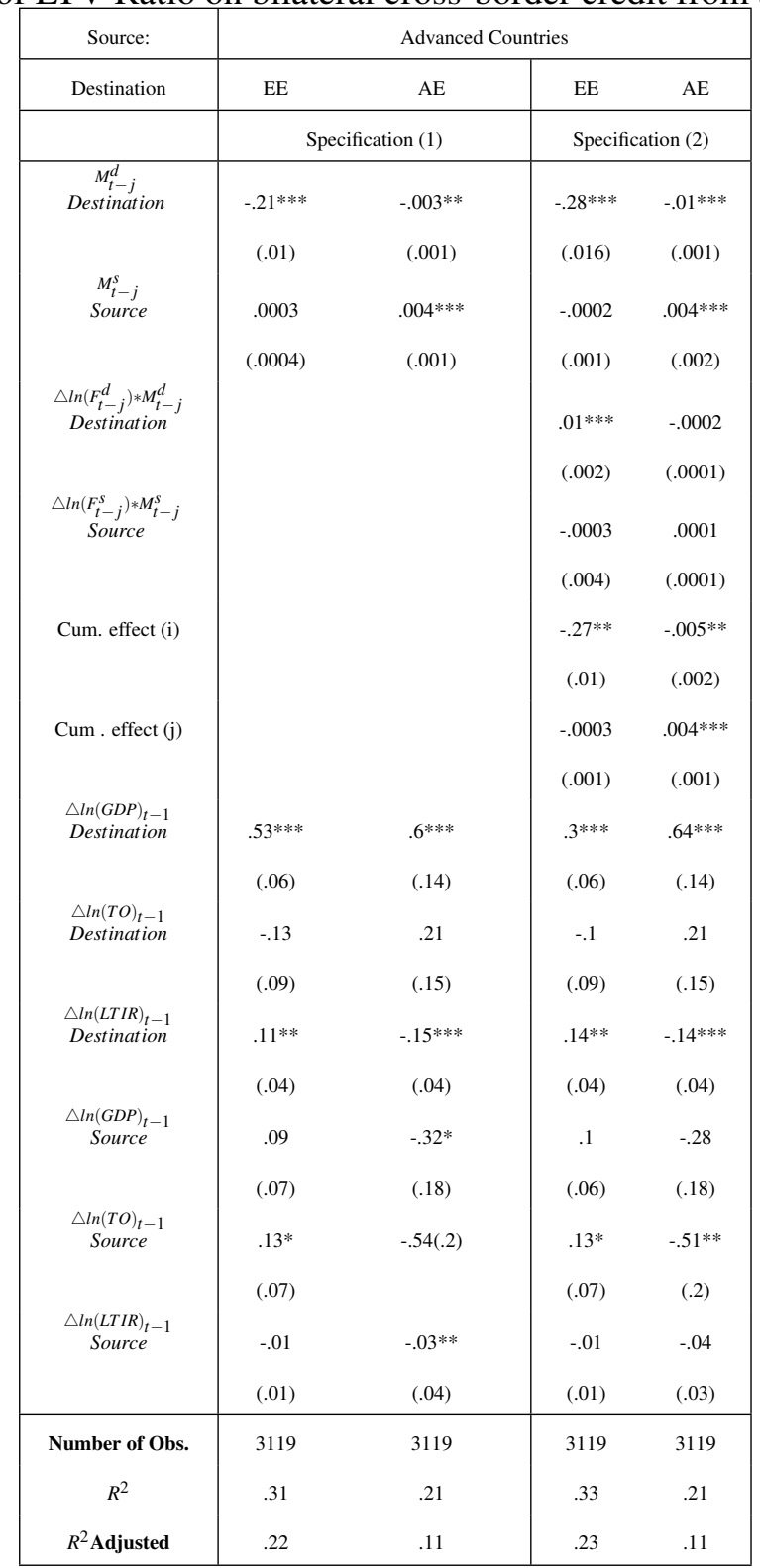

Note: The dependent variable is the growth of bilateral cross-border credit from Advanced Countries (Source Countries) to the Emerging (EE) and Advanced (AE) economies. (1) reports the cumulative effect of stand alone macroprudential policies and control variables on bilateral cross-border credit. (2) extends (1) by including the cumulative effect of the interaction between macroprudential instrument and financial vulnerability variable for destination and source countries.. In each specification, we consider country and time fixed effects. $M$ is LTV ratio macroprudential tool measured as the ratio of household loan over the value of housing price. $d$ is the destination countries and $s$ is the source countries. There 34 destination countries and 15 source countries. TO is trade openness. LTIR is the long term interest rate. $* * *, * *, *$ indicate results significant at the $1 \%, 5 \%$ and $10 \%$ level respectively. Default standard errors are in parathensis (Robust standard errors are similar.) 


\subsection{Conclusion}

In this chapter, we assess the impact of macroprudential policies in the form of capital requirements and LTV ratio on bilateral cross-border credit over the period 2000-2014. We evaluate simultaneously the role of macroprudential policies in the source (lending) and the destination (borrowing) countries. The goal is to obtain an understanding of the contribution of these policies in the lending and borrowing countries to the international macroprudential leakages. Leakages happen when borrowers avoid the policies implemented to reduce credit growth by demanding credit in foreign banks subject to different policy restrictions. This might enable the financial authorities to coordinate policies across countries. We also evaluate if the effectiveness of macroprudential policies is dependent on whether countries involved in international banking activities are financially vulnerable. We use the debt to service ratio as the measure of financial vulnerability. This is an early warning indicator, which has better signaling qualities compared to other indicators. We analyze the effect of the macroprudential policies in emerging countries and advanced economies. We consider the advanced countries to be the lending (or source) countries and we analyze the response to the macroprudential policies on credit demand from advanced, advanced non eurozone and eurozone countries separately. ${ }^{19}$

Using panel data analysis, we find that increasing capital requirements in the destination and source countries is effective in reducing international banking activities. However, for some groups of countries, openness to foreign credit undermines the effectiveness of capital requirements in times of high financial vulnerability. This suggests that during credit booms it is important for policy makers to take into consideration the capital requirements implemented in other countries. Tightening the LTV ratio has less significant international effects. It also has more heterogeneous effects depending on the group of countries examined compared to capital requirements. In some cases, we observe that tight LTV ratios in destination countries increase international credit. This may be due to the fact that there is a high credit demand from a different sector other than the housing sector, the main sector affected by the variation of the LTV ratios. The response of bilateral

\footnotetext{
${ }^{19}$ Emerging countries are eliminated because of the lack of complete data.
} 
credit to the change of most lending countries LTV ratios is statistically insignificant in most cases.

We contribute to the literature by demonstrating that the effect of macroprudential policies on the growth in international credit is heterogeneous across different groups of destination and source countries and that some macroprudential leakage exists in some countries. Hence, coordination of macroprudential policies maybe necessary particularily during periods of high credit booms. In Chapter 3, we employ a two country dynamic stochastic general equilibrium model to investigate how the capital requirements and the LTV ratios can complement each other in reducing their international spillover. 


\section{Chapter 3}

\section{Interaction of Heterogeneous}

\section{Macroprudential Policies}

\subsection{Introduction}

Different authors have demonstrated that macroprudential policies are effective in reducing overborrowing and improving welfare at the national level (see for example Bianchi and Mendoza (2011), Bianchi (2011a,b), Benigno et al. (2013)). In this chapter, we focus on their effectiveness in reducing credit growth in an international context. We take into account the existence of complex financial linkages between countries which may undermine the performance of such policies by making credit available to borrowers through cross-border lending. An analysis of the usefulness of macroprudential policies in reducing credit growth in an international setting is necessary because the interconnection of banking systems and financial markets have played an important role in the propagation of the financial crisis due to the increase of cross-border financial activities. ${ }^{1}$

Cross-border lending has increased considerably since 1999, particularly in European countries. In 2008, cross-border credit between eurozone and European Union (EU) countries increased by 300\% compared to cross-border credit observed in 1999 (see Poutineau and Vermandel (2015)).

\footnotetext{
${ }^{1}$ See for example Ueda (2012) and Justiano et al. (2014).
} 
Furthermore, in EU countries the number of branches of banks from countries other than western European countries increased from 557 in 2003 to 766 in 2009; representing 79\% of all branches of foreign banks operating in EU countries (see Allen et al. (2011)). The existing literature on the international efficiency of the new regulation tools has demonstrated how the lack of coordination of such policies across countries may lead to more costly financial crises (see for example Jeanne (2013), Bengui (2014), Rubio (2016) and Kara (2016)). ${ }^{2}$ For example, Bengui (2014) demonstrates that the presence of a global social planner coordinating liquidity regulation across countries helps to improve all countries' welfare compared to the welfare achieved by national social planner regulating national liquidity. Bengui and Bianchi (2014) look at the circumvention issue in the shadow banking system, in which borrowers avoid regulations by borrowing more from less regulated financial institutions in the same country. Despite, this circumvention, the results of Bengui and Bianchi (2014) show that there is a gain in implementing macroprudential policies even when the policies are applied to only a subset of agents. In fact, macroprudential policies assure financial stability but their effectiveness is undermined as less regulated financial institutions can supply credit while more regulated financial insitutions reduce their credit supply.

In this chapter, we investigate circumvention of macroprudential policies at the international level. We focus on the importance of credit related macroprudential tools applied in the housing market in the form of a LTV ratio that is used to limit borrowing to a fraction of the value of the house, regardless of whether borrowing is from domestic and/or international banks. We also focus on the interaction of capital related macroprudential tools in the form of capital requirement regulations imposed on banks. ${ }^{3}$ We consider that countries with national financial regulators implement macroprudential policies based on the economic situation in their countries. Some countries have stricter regulations than others. Thus, agents borrow more from the less strict banking system if cross-border lending is permitted. Table 3.1 shows that the range of LTV ratios chosen in major industrialized countries goes from $70 \%$ to $90 \%$. Capital requirements also vary across countries

\footnotetext{
${ }^{2}$ Bengui (2014) defines policy coordination as an implementation of regulatory standards across countries based on the consideration of global liquidity shocks which are imperfectly correlated across countries. Rubio (2016) and Kara (2016) define coordination as imposing common regulatory standards across countries.

${ }^{3}$ In this dissertation, capital requirement is defined as the capital adequacy ratio.
} 
(see Table 3.2) . Global banks operating in different countries follow financial regulations implemented in the country where they are headquartered. This affects global credit supply as they have different ability to supply credit internationally. Their regulations are based on the assessment of the banking system, on the historical losses of the banks during a crisis, on the performance of the banks and on their geographical location. For instance, in Germany, banks are required to hold $14.3 \%$ of Common Equity Tier 1 (CET1), whereas in France it is set to $12.5 \%$, and in UK it is equal to $11.8 \%$. Some countries such as Finland and Sweden have even higher CET1 ratios that are set around $18 \%$. The requirements on Austria are among the lowest; as they are set to be $11.2 \%$ of CET1. Under the Basel III, capital requirement regulations consist of requiring banks to hold countercyclical capital buffers in the form of CET1 capital to be used in the time of downturns. ${ }^{4}$

Table 3.1: LTV ratio in the housing sector in different countries

Source: IMF (2008,2014) - EU Report (2016)

\begin{tabular}{|c|c|}
\hline Countries & LTV housing market \\
\hline \hline Netherlands & 0.90 \\
\hline Belgium & 0.83 \\
\hline USA & 0.80 \\
\hline Australia & 0.80 \\
\hline France & 0.75 \\
\hline Canada & 0.80 \\
\hline UK & 0.75 \\
\hline Greece & 0.75 \\
\hline Spain & 0.75 \\
\hline Germany & 0.70 \\
\hline Italy & 0.69 \\
\hline
\end{tabular}

\footnotetext{
4 - Definition of Basel III : http://www.bis.org/bcbs/basel3.htm.

- BIS (2010) defines CET1 capital as :

- Common shares issued by the bank that meet the criteria for classification as common shares for regulatory purposes (or the equivalent for non-joint stock companies);

- Stock surplus (share premium) resulting from the issue of instruments included Common Equity Tier 1;

- Retained earnings;

- Accumulated other comprehensive income and other disclosed reserves;

- Common shares issued by consolidated subsidiaries of the bank and held by third parties (e.g.: minority interest) that meet the criteria for inclusion in Common Equity Tier 1 capital;

- Regulatory adjustments applied in the calculation of Common Equity Tier 1.
} 
Table 3.2: Capital requirements in different countries

Source: EBA(2015)

\begin{tabular}{|c|c|}
\hline Countries & CET1 ratio \\
\hline \hline Finland & $18 \%$ \\
\hline Luxembourg & $17.2 \%$ \\
\hline Belgium & $16.1 \%$ \\
\hline Denmark & $15.4 \%$ \\
\hline Germany & $14.3 \%$ \\
\hline Netherlands & $13.6 \%$ \\
\hline France & $12.5 \%$ \\
\hline EU & $12.8 \%$ \\
\hline UK & $11.8 \%$ \\
\hline Italy & $11.5 \%$ \\
\hline Austria & $11.2 \%$ \\
\hline
\end{tabular}

Many studies use homogeneous macroprudential tools in their analysis whereas we focus on the effect of heterogeneous LTV ratios and capital requirements, given their prevalence in the global economy. Thus, in this study we look at the effect of the prudential tools when countries involved in cross-border lending have different financial regulations. Recent empirical studies demonstrated the impact of heterogeneous tools on credit build up. For instance, Reinhardt and Sowerbutts (2015) empirically show that the existence of heterogeneous financial regulation tools in the banking system, such as capital and reserve requirements, and lending standards applied on specific products may be related to the increase of cross-border lending. Borrowers can circumvent the new policies by borrowing from foreign branches with less capital requirements operating in that foreign country. ${ }^{5}$ In Chapter 2 , we found that in times of credit boom, openness to crossborder credit and heterogeneity of policies reduce the effectiveness of macroprudential policies in reducing bilateral credit growth. In this chapter, we analyze how international coordination and complementarity of different policies may help to improve the effectiveness of these policies in countries that allow cross-border credit.

\footnotetext{
${ }^{5}$ See also Houston et al.(2012) and Aiyar et al. (2012).
} 
We contribute to the literature studying the impact of macroprudential policies by looking at the impact of heterogeneous macroprudential policies in a world where cross-border lending is permitted. We develop a two-country dynamic stochastic general equilibrium (DSGE) model with collateral constrainted investors and global banks in each country. ${ }^{6}$ Housing is the collateral used by investors and it is subject to heterogeneous LTV ratios across countries. Global banks face the capital requirements which are also heterogeneous across countries. The macroprudential policies are the LTV ratios and the capital requirements that adjust with a change in financial indicators such as credit growth, asset prices,credit-to-GDP ratio. We also analyze how coordination and complementarity of different macroprudential policies help to reduce the circumvention of these policies. Houston et al. (2012) were among the first papers to address the problem of circumvention of bank regulations. They consider a larger number of countries for their empirical analysis and use different types of regulation such as reserve requirements. As in Houston et al. (2012), we analyze the impact of bank regulations but we focus on the impact of policies on domestic and international credit growth using a theoretical model. ${ }^{7}$ This methodology allows us to evaluate the impact of macroprudential policies on global credit supply if policymakers would apply our suggested measure of coordination of macroprudential policies. An analysis of a recent crosscountry database on macroprudential policies (see Cerutti et al. (2016) that we discussed in Chapter 2) indicates the existence of non-complementarity between these policies and heterogeneity of the policies across countries. ${ }^{8}$ Our DSGE model is similar to Iacoviello (2015) but extended to an international setting. It includes housing, as this sector played a major role in the global financial crisis. In addition to technology shocks, we also include borrowing capacity shocks, which affect the value of housing for borrowers. We follow Iacoviello and Minetti (2006) and allow investors to borrow from domestic and foreign banks in order to capture the transmission of financial cycles across countries. ${ }^{9} \mathrm{We}$ assume that banks in each country take deposits from both domestic and

\footnotetext{
${ }^{6}$ In Chapter 4, we introduce international financial activities by considering a model with international investors whereas in this chapter we consider a model with international banks.

${ }^{7}$ Houston et al. (2012) use other bank regulations and their effects during the period preceding the 2007 financial crisis.

${ }^{8}$ It means that policies are not tightened at the same time across countries during period of credit expansion.

${ }^{9}$ Iacoviello and Minetti (2006) examines the transmission of international business cycles by allowing investors to
} 
foreign savers and make loans to domestic and foreign investors.

As an insurance to prevent future systemic risk, banks and borrowers face different timevarying macroprudential tools imposed by national financial regulators in each country. Macroprudential policies adjust endogenously with the state of the economy. Specifically, LTV ratios respond when the housing price deviates from its steady state value. Capital requirements change when each country's credit deviates from its steady state value. Since there is no specific measure of how macroprudential policies should be formulated, we are following the existing literature to evaluate the macroprudential policy effects. For example, Bruneau et al. (2016) use a new keynesian model with canadian data to show that countercyclical LTV ratios based on house price deviation from its steady state help to reduce transmission of housing shocks to key macroeconomic variables suchas consumption, credit. ${ }^{10}$ Clerc et al. (2014) consider a closed economy model with capital requirements that change with the deviation of the total bank credit, GDP and the credit to GDP ratio from their steady state values, to analyze the effect of changing banks' capital requirements. One of their main findings is that capital requirements reduce the risks of bank failures and force banks to use their wealth efficiently. ${ }^{11}$

In this chapter, we analyze the effects of productivity and borrowing capacity shocks on key macroeconomic variables in a model with heterogeneous LTV ratios and capital requirements when a country and permit either high or low levels of cross-border lending. ${ }^{12}$ The main questions addressed in this study are the following: i) How effective are macroprudential policies in reducing excessive credit build up when cross border lending is permitted? ii) In this case, is the coordination of macroprudential policy important for integrated countries to mitigate credit growth? iii) Is complementarity of LTV ratio and capital requirements within the country useful to regulate credit growth?

The main results show that increasing capital requirements for domestic banks does not nec-

borrow from domestic and foreign lenders. There are no banks per se in Iacoviello and Minetti (2006) as in Iacoviello (2015), instead there are foreign financiers who are in fact households.

${ }^{10}$ Countercyclical policy refers to a policy that is negatively correlated with economic growth.

${ }^{11}$ See also Rubio (2014b) who uses aggregate output and housing price variation in an active LTV policy.

${ }^{12}$ In this chapter heterogeneous policies implies that the LTV ratios and capital requirements implemented in two countries are different. 
essarily decrease desired credit growth when investors can borrow from foreign banks which do not follow the same tight regulations. The reduction in credit supply by domestic banks is partially offset by an increase in credit supply by foreign banks. The empirical literature studying the effect of capital requirements at the international level finds similar results. ${ }^{13}$ Heterogeneous LTV ratios across countries can still reduce credit build up and be effective despite the existence of cross-border lending. In fact, investors pledge the same collateral (subject to LTV ratio determined by national financial regulators) to domestic and foreigner lenders. We find that coordination of the capital requirements is useful in reducing credit build up. We find that the implementation of time-varying LTV ratio and capital requirements simultaneously within the country experiencing a positive productivity or borrowing capacity shock are more effective in reducing credit build up compared to international coordination of capital requirements. Hence, another contribution of this analysis to the literature is the assessment of different useful strategies in reducing international credit build up which are international coordination of capital requirements and implementation of both LTV ratios and capital requirements prudential tools.

This chapter is organized as follows. We present a discussion of the relevant literature in Section 2. Section 3 describes the DSGE model. Section 4 gives details about the calibration of the model. In Section 5, we analyze the impact of openness to international credit on the effectiveness heterogeneous policies, the impact of international coordination of capital requirements across countries and the influence of complementary policies. Section 6 presents concluding remarks.

\subsection{Literature Review}

This chapter contributes to different strands of literature. It is related to the literature studying the importance of international coordination of financial regulation tools (see for example: Dell'Ariccia and Marquez (2006), Bengui (2014), Rubio (2014b), Kara (2016)). It is also related to the literature analyzing the effectiveness of these tools in controlling credit supply and strength-

\footnotetext{
${ }^{13}$ See for example, our results in Chapter 2, and in Buch and Goldberg (2016), Frost et al.(2016), Ohls et al. (2016) and Damar and Mordel (2016).
} 
ening the financial and banking sectors under the presence of aggregate shocks in open economies (see for example: Benigno et al (2010), Bianchi (2011a), Bianchi and Mendoza (2011), Bianchi and Bengui (2014)). This literature does not take into account the implications of heterogeneous regulations on borrowers and global banking activities which we address in this chapter.

In the context of international coordination of financial regulations, Bengui (2014) refers to the prevention of systemic risk focusing on the risk of liquidity shocks expressed as scarcity of liquid assets. He explores the need for harmonization of liquidity regulation in a multi-country model of liquidity demand using a game theoretic approach to macroeconomic policy coordination. Bengui (2014) focuses on the analysis of liquidity regulation in a global market with domestically minded financial regulators who do not consider externalities from other countries. His results show that the absence of cooperation among regulators is welfare reducing. A liquidity shock can cause a severe and costly financial crisis.

Rubio (2014a) studies the transmission of shocks in monetary union countries with heterogeneous housing markets. She allows for heterogeneity in the levels of LTV ratios across countries and also for fixed or variable mortgage interest rates (which vary among countries within the European Union). The results of the study show that transmission of shocks depends on how relaxed LTV ratios are across countries. Rubio (2014b) expands on Rubio (2014a) by examining the importance of coordination of LTVs across countries under heterogeneous mortgage contracts. She looks at the welfare effect of different designs of LTV ratios (when the LTV ratios adjust to either the state of the individual economy or the state of the global economy). Rubio (2014b) concludes that the design of macroprudential policies affects welfare when countries have different mortgage contracts, whereas differences in LTV ratios or differences in the number of borrowers across countries do not affect welfare. Rubio (2016) analyzes the welfare implications of coordinated LTV ratios within the euro area. She finds that there is a welfare gain if all countries implement similar macroprudential policies.

The research of Kara (2016) is similar to this chapter as it focuses on the importance of national regulators cooperation and the presence of systemic risk in global financial markets. It differs 
from our paper as we focus on the global banking system instead of global investment as in Kara (2016). He uses a two-country and three-period model where asset returns are asymmetric. It is assumed that the level of productivity of lenders is different between countries. The results show that cooperation is more beneficial for countries that are more similar than for countries that are different. Only countries which get the same return from investing in risky assets will accept to apply the same level of financial regulation tools because coordination can reduce country's investment return. The analysis relies on a game theoretic approach to evaluate the incentive of financial regulators of different countries to cooperate.

Dell'Ariccia (2006) demonstrates the benefits and costs of regulatory union in financially integrated jurisdictions. This author finds that symmetric countries benefit more from centralized regulators than asymmetric countries. ${ }^{14}$ This is because coordinated policies would mean that asymmetric countries lose to some extent the ability to modify policies when they need to address country specific issues. However, symmetric countries make any policy adjustment at the same time, therefore coordination is possible. Credit competition among lenders increases the incentive of national regulators to reduce capital requirement since they reduce bank profits. Our analysis is different from Dell'Ariccia (2006) in two main ways. First, in Dell'Ariccia's paper capital requirements imposed on banks are constant, whereas we use endogenous capital requirements. Second, Dell'Ariccia (2006) focuses on the effects of similar and different regulation level on bank profitability, while we focus on the effects on aggregate credit growth. Hence, in our study we focus on minimizing the risk taking of borrowers to prevent a financial crisis. In the same vein, Acharya (2003) shows that the effectiveness of capital requirements depends on differences in ex-post policies such as bailout policies between countries. The heterogeneity of bailout policies across countries causes global banks to have different cross-border banking activities. Thus banks from countries with less strict bailout policies will be more competitive and increase credit supply domestically and abroad which undermines the efficacy of capital requirements. We contribute to this literature by analyzing the effect of coordinated macroprudential policies on credit sup-

\footnotetext{
${ }^{14}$ Countries are symmetric because bank capital is the same across countries.
} 
ply when cross-border lending is permitted and macroprudential policies are heterogeneous across countries. In this chapter, we assume that borrowing capacity shocks and technology shocks trigger excessive credit growth and analyze how coordination of macroprudential policies across countries can help to mitigate the excessive increase of credit.

The second literature strand is related to the quantitative assessment of capital regulation tools. Unlike our analysis, this second category of the literature has not addressed the aspect of crossborder banking activities in their models and have not studied the global effects of macroprudential policies. Bianchi (2011a) finds that with macroprudential instruments, a social planner is able to increase welfare more than any other crisis management policy in a time of credit growth. To demonstrate this, he develops a DSGE model of small open economy with two goods and financial frictions. He assumes that an economic agent's debt cannot exceed a fraction of the income from tradable and non-tradable sectors. In his paper, he uses a variety of tools (taxes, reserve and capital requirements) to analyze how they reduce over-borrowing and proves that they help to reduce over-borrowing in the same proportion.

Bianchi and Mendoza (2011) develop a DSGE model with an occasionally binding collateral constraint on debt to distinguish periods of over-borrowing from normal borrowing. They compare the welfare of the social planner and private agents in a competitive equilibrium in times of crises, with and without macroprudential tools being in place. Taxes on debt and on dividends are used as macroprudential tools in their model. Their findings show that the welfare of the social planner is higher than the welfare of an economic agent in a competitive equilibrium. The social planner is able to take into consideration the effects of his borrowing decisions on the market prices of assets and labor and internalize the effect of borrowing. Implementing macroprudential policies helps private agents to internalize the effects of their borrowing decisions and therefore give the same welfare as the social planner. Jeanne and Korineck (2010) investigate the welfare implications of macroprudential instruments in the form of Pigouvian taxation on capital inflows using a small open economy model with one tradable good. They obtain an optimal tax that can help consumers to internalize the effects of borrowing internationally. 
Bianchi et al. (2011) show that the interaction between financial innovation, credit frictions and imperfect information causes the transmission of the financial shock in a DSGE model. They examine the implications of macroprudential policies in the form of a Pigouvian tax on debt and on dividends. They consider two alternative assumptions about information processing. The first one is when the planner has full information on the true transition probabilities across financial regimes. The second case is when the planner is learning about changes in the financial environment. Their main results show the importance of information held by policymakers for macroprudential policies to be more effective. When an economy experiences a financial crisis, asset prices and the ability of an economic agent to borrow and to consume change minimally if a planner has full information about the fluctuations of credit conditions and the change of financial regimes is increasing or decreasing the ability of economic agents to borrow over time. Benigno et al. (2013) develop a two-sector small open economy model with an occasionally binding borrowing constraint and compare the effects of ex-ante policies (referring to macroprudential policies in the form of tax on debt implemented in normal times) and the effects of ex-post policies (referring to policies implemented during the crisis time). The main conclusion is that ex-ante policies reduce the probability of a crisis and reduce the average level of debt, consumption and production because they are costly. Thus imposing taxes on debt as a preventive tool creates a situation of underborrowing and therefore reduces welfare. Ex-post policies produce the highest welfare in this context. Benigno et al. (2013) consider the problems related to the limitation of enforceability of debt contracts (i.e. the limitation of commitment to honor debt contracts) as in Kiyotaki and Moore (1997) by using a collateral constraint.

Although their motivation was not to address issues related to systemic risk, Aiyar et al. (2014a), (2014b) empirically demonstrate the existence of heterogeneous capital requirements in the British credit system. Aiyar et al. (2014a) identify branches of foreign banks subject to lower regulations as channels of credit substitution when capital requirements change in the UK. For example, they find that foreign banks operating as affiliated foreign branches increased lending more than non-affiliated branches. Affiliated branches tend to lend more because they have the 
ability to lend at lower transaction costs. Aiyar et al. (2014b) evaluate how capital requirement changes affected credit supply in the UK. They find that after the change in capital requirements in the UK, unregulated banks operating in the country increased the supply of credit. Hence, their results emphasized the need for cooperation among financial regulators across countries to prevent leakages from heterogeneous macroprudential policies.

This chapter extends the work of Iacoviello (2015) to a two country model with endogenous macroprudential policy. We borrow some of aspects of the formulation of the borrowing constraint from Iacoviello and Minetti (2006) to capture the importance of the cross-border lending. Iacoviello and Minetti (2006) analyzes the transmission of shocks between countries through financial liberalization of the banking sector. His findings show that the existence of domestic and foreign lenders explain the comovement of shocks across countries. Our analysis is different from Iacoviello and Minetti (2006) in the sense that we consider a two-country model with a banking sector where domestic and foreign banks are subject to different banking regulations while operating in both countries.

\subsection{Model}

\section{Environment and main assumptions}

The theoretical framework comprises of two countries with three types of infinitely lived agents (savers, investors, and banks). Each country produces a common tradable good. Savers are assumed to be the most patient agents in the economy. They work in firms, earn a wage, consume and invest in firm's production. The return from the latter constitutes part of their income. They also save and receive a return from their deposits. Savers accumulate domestic housing. For simplificity, we assume that investors in each country accumulate capital which they invest into domestic firms. ${ }^{15}$ Investors are assumed to be more impatient than savers. They borrow from banks to invest

\footnotetext{
${ }^{15}$ Our objective is to analyze the effect of domestic financial regulations on bank credit supply, allowing investors to invest in domestic and foreign firms will not add much to the results. This model differs from the model in Chapter 4 where we allow investors to invest in both countries to account for the transmission of shocks between two countries.
} 
in firms. They pay back their debt with interest every period. Investors are constrained in their borrowing to a fraction of their house's value in each period. Housing is important for investors for two main reasons: it is used as a collateral and it is also used as a factor of production (it is commercial real estate). ${ }^{16}$

Banks are internationally active. Savers deposit their savings in banks headquartered in their own country while investors can borrow from domestic or foreign banks. Banks can freely convert deposits into loans to domestic and foreign investors. Banks get utility from private consumption equivalent to the profits they make by acting as intermediaries between borrowers and savers. Banks maximize consumption which is equivalent to the standard problem of financial intermediaries maximizing profit. ${ }^{17}$ Domestic and foreign banks adhere to the financial regulations formulated and implemented by national regulators.

There are two main differences between this model that that in Iacoviello (2015). First, banks are internationally active and are subject to active macroprudential policies in our model. Second, financial regulations tools, LTV ratio and capital requirements, adjust with variations in the asset price and the credit supply in the economy, respectively.

\section{Savers}

For savers in country $i$, denote $C_{S, t}^{i}$ as consumption of the tradable good, $H_{S, t}^{i}$ as housing demand, $K_{S, t}^{i}$ as capital investment, $N_{t}^{i}$ as labor supply and $D_{t}^{i}$ as deposited savings in the saver's home country bank. A representative saver in country $i$ maximizes expected discounted lifetime utility given by:

$$
E_{0} \sum_{t=0}^{\infty} \beta_{S}^{t}\left(\log C_{S, t}^{i}+\varphi \log H_{S, t}^{i}+\tau \log \left(1-N_{t}^{i}\right)\right)
$$

where $E_{0}$ is the expectation operator, $\beta_{S}^{t}\left(0<\beta_{S}<1\right)$, is the discount factor for savers, $\varphi$ represents the housing demand parameter, and $\tau$ is the labor supply parameter. The representative saver

\footnotetext{
${ }^{16}$ See Iacoviello (2015).

${ }^{17}$ See for example Iacoviello (2015).
} 
maximizes (3.1) subject to the following budget constraint:

$$
\begin{gathered}
C_{S, t}^{i}+K_{S, t}^{i}-(1-\delta) K_{S, t-1}^{i}+q_{t}^{i} H_{S, t}^{i}+D_{t}^{i}= \\
W_{t}^{i} N_{t}^{i}+q_{t}^{i} H_{S, t-1}^{i}+R_{K_{S}, t}^{i} K_{S, t-1}^{i}+R_{D, t-1}^{i} D_{t-1}^{i}
\end{gathered}
$$

Every period, a saver accumulates capital which depreciates at the rate $\delta,(0<\delta<1)$. Let $q_{t}^{i}$ be the real price of housing, $W_{t}^{i}$ be the the wage received from labor supply, $R_{K_{S}, t}^{i}$ be the rate of return oncapital investment in the firm which is producing the tradable good and $R_{D, t-1}^{i}$ be the rate of return from deposits in the home country banks.

\section{Investors}

For investors in country $i$, denote $C_{I, t}^{i}$ as the consumption of the tradable good, $K_{I, t}^{i}$ as capital investment, $H_{I, t}^{i}$ as the housing demand, $L_{t}^{i i}$ and $L_{t}^{i j}$ denote the amount of the loans borrowed from domestic $(i)$ and foreign $(j)$ banks respectively. ${ }^{18}$ A representative investor in country $i$ maximizes expected discounted lifetime utility given by:

$$
E_{0} \sum_{t=0}^{\infty} \beta_{I}^{t} \log C_{I, t}^{i}
$$

where $\beta_{I}^{t}\left(0<\beta_{I}<1\right)$ is the discount factor for investors. It is assumed that savers are more patient than investors and therefore, $\beta_{I}<\beta_{S} \cdot{ }^{19}$ The country $i$ investor's budget constraint is given by:

\footnotetext{
${ }^{18}$ The first superscript is where the investor is and the second superscript indicates the country where the bank is headquartered.

${ }^{19}$ This assumption allows us to have on one hand savers who are willing to consume less and build up savings in the banks and on the other hand we have investors who demand the deposited savings from the banks to use them for investment opportunities.
} 


$$
\begin{gathered}
C_{I, t}^{i}+R_{L, t-1}^{i} L_{t-1}^{i i}+R_{L, t-1}^{j} L_{t-1}^{i j}+q_{t}^{i} H_{I, t}^{i}+K_{I, t}^{i}-(1-\delta) K_{I, t-1}^{i}= \\
q_{t}^{i} H_{I, t-1}^{i}+R_{K, t}^{i} K_{I, t-1}^{i}+R_{H, t} q_{t}^{i} H_{I, t-1}^{i}+L_{t}^{i i}+L_{t}^{i j}
\end{gathered}
$$

The right hand side of the equation presents the source of revenue, whereas the left hand side presents the expenses. In each period, the investor, consumes the tradable good, pays back the last period loan with interest to domestic and foreign lenders, $R_{L, t-1}^{i} L_{t-1}^{i i}$ and $R_{L, t-1}^{j} L_{t-1}^{i j}$ respectively. $^{20}$ The investor accumulates housing at price $q_{t}^{i}$. Each period, the investor gets a return $R_{K t}^{i}$ and $R_{H, t}^{i}$ on capital investment and housing investment, respectively.

The country $i$ investor faces two borrowing constraints that are defined as follows:

$$
\begin{gathered}
L_{t}^{i i} \leq \chi_{t}^{i} \kappa_{t}^{i} \varepsilon^{i} q_{t}^{i} H_{I, t}^{i} \\
L_{t}^{i j} \leq \chi_{t}^{i} \kappa_{t}^{i}\left(1-\varepsilon^{i}\right) q_{t}^{i} H_{I, t}^{i}
\end{gathered}
$$

We consider that the borrowing constraints always bind. $\chi_{t}^{i}$ is the borrowing capacity shock which can be interpreted as a general credit shock for investors. If this is positive, it gives investors the ability to increase credit and in turn increase investment in the firm's production. $\kappa_{t}^{i}$ is the LTV ratio which is expressed as time-varying (or active) macroprudential tool in (3.8) below. Following Iacoviello and Minetti (2006), we consider that investors use a share $\varepsilon^{i}\left(0<\varepsilon^{i}<1\right)$ of real estate as a domestic collateral and a share $1-\varepsilon^{i}$ of real estate as international collateral on cross-border borrowing. We assume that $\varepsilon^{i}$ is exogeneous. Thus, the loan received from domestic banks is equal to the value of the share of real estate used as domestic collateral and the loan received from foreign banks is equal to the value of the share of real estate used as foreign collateral. In this context, the borrowing capacity shock may capture the change of the quality of the house pledged

\footnotetext{
${ }^{20}$ The first superscript represents the origin of the borrower and the second superscript represents the origin of the bank imposing the leverage ratio.
} 
as a collateral and is formulated as in Bruneau et al. (2016), or it can be interpreted as a general credit shock. The borrowing capacity shock is assumed to follow an AR(1) process:

$$
\log \left(\chi_{t}^{i}\right)=\rho_{\chi} \log \left(\chi_{t-1}^{i}\right)+v_{\chi, t}^{i}
$$

where $\rho_{\chi}$ is the parameter capturing the persistence of the borrowing capacity shock and $v_{\chi, t}^{i} \sim$ $\operatorname{iid}\left(0, \sigma_{\chi}^{2}\right)$.

Following the recent literature on macroprudential policies the LTV ratio is formulated as follows: 21

$$
\kappa_{t}^{i}=\kappa^{i}\left(\frac{q_{t}^{i}}{q^{i}}\right)^{-\phi_{q}}
$$

where $\kappa^{i}$ is the steady state value of the LTV and $\frac{q_{t}^{i}}{q^{i}}$ represents the deviation of the housing price in country $i$ from its steady state value. The parameter $\phi_{q}$ captures the responsiveness of the LTV ratio to the asset price and is chosen by the financial regulators. Regulators can impose tighter borrowing conditions by increasing $\phi_{q}$. We use the label "active policy" to indicate a situation with $\phi_{q} \neq 0$. If $\phi_{q}$ is zero and and the LTV ratio $\kappa_{t}^{i}$ is constant, we use the label "passive policy". Each investor maximizes utility (3.3) subject to the budget constraint (3.4), borrowing constraints (3.5) and (3.6), given the process for the borrowing capacity shock in (3.7) and the active LTV ratio in (3.8).

\section{Banks}

Each country has an internationally active bank that operates in both countries, through the creation of bank branches. Financial regulators in each country implement active macroprudential policy on banks in the form capital requirement regulations. Banks collect deposits from savers in their own country and return them with interest the next period. They grant loans to domestic and foreign borrowers who pay back their debt with a loan interest rate higher than the interest rate banks

\footnotetext{
${ }^{21}$ See for example Clerc et al. (2014), Rubio and Carraso-Gallego (2014), and Bailliu et al. (2015).
} 
pay to savers so that banks make a profit. With capital requirements, banks are allowed to lend investors such that the sum of total global loans granted to all borrowers is less than or equal to a multiple of bank deposits.

Let $C_{B, t}^{i}$ denote the bank's consumption (which is equivalent to profits received from intermediation). Each bank's objective is to maximize utility by choosing $C_{B, t}^{i}, D_{t}^{i}, L_{t}^{i}$ to

$$
E_{0} \sum_{t=0}^{\infty} \beta_{B}^{t} \log C_{B, t}^{i}
$$

subject to the budget constraint:

$$
C_{B, t}^{i}+R_{D, t-1}^{i} D_{t-1}^{i}+L_{t}^{i}=R_{L, t-1}^{i} L_{t-1}^{i}+D_{t}^{i}
$$

and to the borrowing constraint :

$$
D_{t}^{i} \geq \gamma_{t}^{i} L_{t}^{i}
$$

where $\beta_{B}^{t}\left(0<\beta_{B}<1\right)$ is the bank's discount factor. Each period, a bank in country $i$ receives revenue from deposited funds by savers and loan repayment by investors (left hand side of equation (3.10)). With this revenue, the bank pays interest to savers and lends to domestic and foreign investors and receive profit. The total lending by banks from country $i$ is given by $L_{t}^{i} \equiv L_{t}^{i i}+L_{t}^{j i}$. After paying the return on savings and receiving the return on lending to home and domestic borrowers, the rest of the revenue is profit. Equation (3.11) is the borrowing capacity constraint faced by banks, where $\gamma_{t}^{i}$ is imposed by the financial regulators. We assume that the borrowing constraint is binding in equilibrium. ${ }^{22}$ The bank capital requirement adjusts to the deviation of the total credit supplied from its steady state value:

$$
\gamma_{t}^{i}=\gamma^{i}\left(\frac{L_{t}^{i}}{L^{i}}\right)^{-\phi_{b}}
$$

$\gamma^{i}\left(0<\gamma^{i}<1\right)$ is the minimum capital requirement imposed on the country $i$ bank and $\frac{L_{t}^{i}}{L^{i}}$ denotes the deviation of the total credit supplied in country $i$ from its steady state value. Thus capital

\footnotetext{
${ }^{22}$ The capital requirements can be defined as $\left(1-\gamma_{t}^{i}\right)=\frac{\left(L_{t}^{i}-D_{t}^{i}\right)}{L_{t}^{i}}$.
} 
requirements are formulated as an active macroprudential policy. ${ }^{23} \phi_{b}$ captures the responsiveness of capital requirement to credit supply and its value is chosen by the policymaker. If $\phi_{b}$ is non zero we use the label "active policy". If $\phi_{b}$ is zero and $\gamma_{t}^{i}$ is constant, we use the label "passive policy".

\section{Producers}

Firms are competitive and produce a tradable homogeneous good by choosing capital (provided by investors and savers), housing (supplied by investors) and labor (supplied by savers). The production function is given by:

$$
Y_{t}^{i}=A_{t}^{i}\left(K_{I, t-1}^{i}\right)^{\alpha \mu}\left(K_{S, t-1}^{i}\right)^{\alpha(1-\mu)}\left(H_{I, t-1}^{i}\right)^{v} N_{t-1}^{i(1-\alpha-v)}
$$

where $A_{t}^{i}$ is a shock to the total factor productivity. Parameter $\alpha(0<\alpha<1)$ is the capital income share, $\mu(0<\mu<1)$ specifies the capital share of investors and $v(0<v<1)$ is the housing share of investors. Savers supply labor inelastically.

Both countries have the same technology, but are subject to heterogeneous temporary shocks to total productivity according to the following VAR(1) technology shock process:

$$
\ln \left[\begin{array}{c}
A_{t}^{i} \\
A_{t}^{j}
\end{array}\right]=\left[\begin{array}{ll}
\rho_{A} & \theta_{A} \\
\theta_{A} & \rho_{A}
\end{array}\right] \ln \left[\begin{array}{c}
A_{t-1}^{i} \\
A_{t-1}^{j}
\end{array}\right]+\left[\begin{array}{c}
v_{A, t}^{i} \\
v_{A, t}^{j}
\end{array}\right], M N\left(\left[\begin{array}{l}
0 \\
0
\end{array}\right],\left[\begin{array}{cc}
\sigma_{A}^{2} & \omega_{A}^{i, j} \sigma_{A}^{2} \\
\omega_{A}^{i, j} \sigma_{A}^{2} & \sigma_{A}^{2}
\end{array}\right]\right)
$$

where $\rho_{A}$ is the parameter capturing the persistence of the technology shock, $\theta_{A}$ allows for shocks to spillover from one country to the other. $\omega_{A}^{i, j}$ is the correlation between the technology shocks in both countries and $\sigma_{A}^{2}$ is the variance of the shock.

\footnotetext{
${ }^{23}$ There is no specific design of prudential tools. We follow the literature for using capital requirements, please see for example, Baillu et al. (2015) and Rubio (2016).
} 


\section{Resolution of the model}

The saver's maximization problem is to $\max (3.1)$ subject to (3.2). The saver's efficiency conditions can be expressed as :

$$
\begin{gathered}
\frac{q_{t}^{i}}{C_{S, t}^{i}}=\frac{\varphi}{H_{S, t}^{i}}+E_{t}\left[\beta_{S} \frac{q_{t+1}^{i}}{C_{S, t+1}^{i}}\right] \\
\frac{W_{t}^{i}}{C_{S, t}^{i}}=\frac{\tau}{1-N_{t}^{i}} \\
\frac{1}{C_{S, t}^{i}}=E_{t}\left[\beta_{S} \frac{1}{C_{S, t+1}^{i}} R_{D, t}^{i}\right] \\
\frac{1}{C_{S, t}^{i}}=E_{t}\left[\beta_{S} \frac{1}{C_{S, t+1}^{i}}\left(1-\delta+R_{K_{S}, t+1}^{i}\right)\right]
\end{gathered}
$$

Equation (3.15), the intertemporal condition for housing, indicates that the marginal utility of acquiring housing is equal to the present and next period costs of the asset. The intratemporal labor supply choice of savers is given by the efficiency condition in (3.16). Equation (3.17) has the form of a standard intertemporal Euler equation. It shows that the marginal utility of savingin time $t$ is equal to the expected discounted marginal utility of consumption in $t+1$ of the savings return from bank deposits. Equation (3.18) shows that for savers the marginal utility of saving in time $t$ is equal to the expected discounted marginal utility of consumption in $t+1$ of the savings return from investing in capital.

The investor's maximization problem is to maximize (3.3) subject to (3.4) to (3.6). The investor's efficiency conditions are:

$$
\begin{gathered}
\frac{q_{t}^{i}}{C_{I, t}^{i}}=\beta_{I} E_{t}\left[\frac{1}{C_{I, t+1}^{i}}\left(q_{t+1}^{i}\right)\left(1+R_{H, t+1}^{i}\right)\right] \\
+\left[\mu_{I, t}^{i} \chi_{t}^{i} \kappa_{t}^{i} \varepsilon^{i} q_{t}^{i}+\mu_{I, t}^{j} \chi_{t}^{i} \kappa_{t}^{i}\left(1-\varepsilon^{i}\right) q_{t}^{i}\right]
\end{gathered}
$$




$$
\begin{gathered}
\frac{1}{C_{I, t}^{i}}=E_{t}\left[\beta_{I} \frac{1}{C_{I, t+1}^{i}} R_{L, t}^{i}\right]+\mu_{I, t}^{i} \\
\frac{1}{C_{I, t}^{i}}=E_{t}\left[\beta_{I} \frac{1}{C_{I, t+1}^{i}} R_{L, t}^{j}\right]+\mu_{I, t}^{j} \\
\frac{1}{C_{I, t}^{i}}=E_{t}\left[\beta_{I} \frac{1}{C_{I, t+1}^{i}}\left(1-\delta+R_{K_{I}, t+1}^{i}\right)\right]
\end{gathered}
$$

The efficiency conditions of borrowers are different from those of savers. Unlike the standard Euler equation, the Euler equation in (3.19) indicates that the marginal utility of housing today is equal to the costs of housing and the marginal utility of credit to the investor. Equations (3.20) and (3.21) are the consumption Euler equations stating that the marginal utility of consumption today is equal to the marginal gain of consumption tomorrow plus the extra unit debt received from home banks (for equation (3.20)) and from foreign banks (for equation (3.21)). $\mu_{I, t}^{i}$ and $\mu_{I, t}^{j}$ are the investor's shadow value of borrowing from domestic and foreign banks, respectively. Equation (3.22) shows that for investors the marginal utility of saving in time $t$ is equal to the expected discounted marginal utility of consumption in $t+1$ of the savings return from investing in capital.

The bank's problem is to maximize (3.9) subject to (3.10) and (3.11). The bank's efficiency conditions for loans and deposits are respectively:

$$
\begin{gathered}
\frac{1}{C_{B, t}^{i}}=\beta_{B} E_{t} \frac{1}{C_{B, t+1}^{i}}\left[R_{L, t}^{i}\right]+\gamma_{t}^{i} \mu_{B, t}^{i} \\
\frac{1}{C_{B, t}^{i}}=\beta_{B} E_{t} \frac{1}{C_{B, t+1}^{i}}\left[R_{D, t}^{i}\right]+\mu_{B, t}^{i}
\end{gathered}
$$

In the equation (3.23) the marginal utility of consumption today exceeds the marginal utility of consumption tomorrow by the marginal utility of one unit of debt a bank gives to domestic and foreign borrowers. Equation (3.24) implies that the marginal utility of bank's consumption is function of the borrowing conditions in the economy since $\mu_{B, t}^{i}$ is assumed to be greater than zero 
and a low steady state value of $\gamma_{t}^{i}$ will increase the marginal utility of bank's consumption. $\mu_{B, t}^{i}$ is the shadow value of borrowing. Thus, if banks borrow more from savers, the cost of holding savers deposits increases. Investors loan interest rate increases as well.

Firm in country $i$ produces a tradable good and chooses capital, labor and commercial real estate to maximize its profit:

$$
\underset{\left\{K_{I, t-1}^{i}, K_{S, t-1}^{i}, H_{I, t-1}^{i}, N_{t}^{i}\right\}}{\operatorname{Max}}\left\{Y_{t}^{i}-R_{K_{I}, t}^{i} K_{I, t-1}^{i}-R_{K_{S}, t}^{i} K_{S, t-1}^{i}-R_{H, t}^{i} q_{t}^{i} H_{I, t-1}^{i}-W_{t}^{i} N_{t}^{i}\right\}
$$

subject to (3.13) and (3.14). The output is produced with a combination of capital and commercial real estate supplied by investors and capital and labor supplied by savers. From the first order conditions of firm's problem we have:

$$
\begin{gathered}
R_{K_{I}, t}^{i} K_{I, t-1}^{i}=\alpha \mu Y_{t}^{i} \\
R_{K_{S}, t}^{i} K_{S, t-1}^{i}=\alpha(1-\mu) Y_{t}^{i} \\
R_{H, t}^{i} q_{t}^{i} H_{I, t-1}^{i}=v Y_{t}^{i} \\
W_{t}^{i} N_{t}^{i}=(1-\alpha-v) Y_{t}^{i}
\end{gathered}
$$

Equations to (3.26) - (3.28) tell us that the marginal benefits of investors and savers receive from investing capital and housing in the firm's production are equal to their marginal costs. Equation (3.29) gives that the firm adjusts labor demand such that the marginal benefit is equal to the marginal cost which given by the wage. 


\section{Market clearing conditions:}

All markets clear in equilibrium. Labor market clearing implies:

$$
N_{t}^{s}=N_{t}^{d}
$$

The total labor supplied by households is equal to the labor demand. The assets market in the home country:

$$
K_{S, t}^{i}-(1-\delta) K_{S, t-1}^{i}+K_{I, t}^{i}-(1-\delta) K_{I, t-1}^{i}=I_{t}^{i}
$$

Total housing supply is exogenous and normalised to unity:

$$
H_{I, t}^{i}+H_{S, t}^{i}=1
$$

The world resource constraint is given by:

$$
C_{I, t}^{i}+C_{I, t}^{j}+C_{S, t}^{i}+C_{S, t}^{j}+C_{B, t}^{i}+C_{B, t}^{j}+I_{t}^{i}+I_{t}^{j}=Y_{t}^{i}+Y_{t}^{j}
$$

\section{Competitive Equilibrium definition}

Taking $\kappa^{i}, \kappa^{j}, \gamma^{i}, \gamma^{j}$ and the initial assets holdings as given, a competitive equilibrium for this economy is an allocation of $\left\{C_{I, t}^{i}, H_{I, t}^{i}, L_{t}^{i i}, L_{t}^{i j}, K_{I, t}^{i}, Y_{t}^{i}\right\}_{t=0}^{\infty}$ for investors in each country, an allocation of $\left\{C_{S, t}^{i}, H_{S, t}^{i}, D_{t}^{i}, N_{t}^{i}\right\}_{t=0}^{\infty}$ for savers in each country and $\left\{C_{B, t}^{i}, D_{t}^{i}, L_{t}^{i i}, L_{t}^{i j}\right\}_{t=0}^{\infty}$ for banks in each country, $\left\{K_{I, t}^{i}, K_{S, t}^{i}, H_{I, t}^{i}, N_{t}^{i}\right\}_{t=0}^{\infty}$ for firms and relative prices $\left\{W_{t}^{i}, R_{K_{I, t}}^{i}, R_{K_{S} t}^{i}, q_{t}^{i}, W_{t}^{j}, q_{t}^{j}, R_{D_{S}, t}^{i}, R_{L, t}^{i}, R_{L, t}^{j}\right\}_{t=0}^{\infty}$ in both countries such that :

- Given prices, investors, savers and banks maximize their utilities subject to their budget and borrowing constraints.

- Firms maximize profits taking the prices as given. 
- The market clearing conditions are satisfied.

\subsection{Parameters values}

We choose parameter values based on those used in the literature, in particular many are taken from Iacoviello (2015) unless otherwise stated. The discount factors for savers, investors and banks $\beta_{S}, \beta_{I}, \beta_{B}$ are set to $0.99,0.94$ and 0.945 , respectively. The discount factors are chosen so that the deposit and loan interest rates be equal to .03 and .05 , respectively. The housing preference

parameter $\left(\varphi^{i}\right)$ for savers is equal to 0.075 which corresponds to the real estate wealth to output ratio of 3.1 (of which 0.8 is from commercial real estate and 2.3 is residential real estate). Investors use capital and their housing (as commercial real estate) in production. The labor supply parameter $\tau$ is equal to 2 . Housing does not depreciate, whereas capital depreciates at the rate of $\delta$ which is set equal to 0.025 .

We allow the parameters of cross border lending, $\varepsilon^{h}$ and $\varepsilon^{f}$, to have different values. The highest degree of cross border lending is fixed at 0.3 and the lowest is 0.01 . The choice is based on Poutineau and Vermandel (2015) who show that the highest level of cross-border banking activities within EMU countries was around $30 \%$ before the financial crisis. We set the persistence parameter $\rho_{\chi}$ and the standard deviation of the AR(1) borrowing capacity shock equal to 0.839 and 0.0204 , respectively. We use the highest and the lowest values of the LTV ratios from Table 3.1 and set the values of $\kappa^{i}$ and $\kappa^{j}$ to be .70 and .90 , respectively. Following Beau et al. (2011) and Bailliu et al. (2015), the coefficient measuring the responsiveness of LTV ratio to the deviation of the housing price from its steady state, $\phi_{q}$, is set equal to 0.5 in both countries.

We use the highest and the lowest value of the capital requirements from Table 3.2 and allow the values for capital requirements, $\gamma^{i}$, to change between .80 and .90 (standard values used in the literature). Following Beau et al. (2011) and Bailliu et al. (2015), the coefficient measuring the responsiveness of capital requirements to the deviation of credit supply from its steady state, $\phi_{b}$, is set equal to 0.5 in both countries. 
The total capital share in production, $\alpha$, is set equal to 0.35 . The parameters are the capital share of investors, $\mu$, is set equal to 0.46 and the housing share used in the production, $v$, is set equal to 0.04 .

We follow Backus et al. (1992) and use their parameter values for the VAR(1) process for the productivity shocks. The persistence parameter, $\rho_{A}$, is set equal to 0.906 , the spillover parameter, $\omega_{A}^{i, j}$, is set equal to .088 , the standard deviation is set equal to 0.0085 and the correlation coefficient between the shocks is set equal to 0.258 .

Table 3.3: Parameters values

\begin{tabular}{|c|c|c|c|}
\hline Parameter & & Value & Source \\
\hline \hline Saver discount factor & $\beta^{S}$ & 0.99 & Iacoviello (2015) \\
\hline Investor discount factor & $\beta^{I}$ & 0.94 & Iacoviello (2015) \\
\hline Bank discount factor & $\beta^{B}$ & 0.945 & Iacoviello (2015) \\
\hline Housing preference share in steady state & $\varphi$ & 0.075 & Iacoviello (2015) \\
\hline Labor supply parameter & $\tau$ & 2 & Iacoviello (2015) \\
\hline Capital depreciation rate & $\delta$ & 0.025 & Iacoviello (2015) \\
\hline Openness to cross-border credit & $\varepsilon$ & $0.3-0.01$ & Poutineau and Vermandel, (2015) \\
\hline persistence parameter ( borrowing capacity shock) & $\rho_{\chi}$ & 0.839 & Iacoviello (2015) \\
\hline Standard deviation ( borrowing capacity shock) & $\sigma_{\chi}$ & 0.02 & Iacoviello (2015) \\
\hline LTV ratio & $\kappa^{i}$ & $0.7-0.9$ & IMF(2008,2014)-EU Report (2016) \\
\hline Credit parameter LTV rule & $\phi_{q}$ & 0.5 & Bailliu et al. (2015) \\
\hline Capital requirements & $\gamma^{i}$ & $0.8-0.9$ & EBA (2015) \\
\hline Credit parameter capital requirements rule & $\phi_{b}$ & 0.5 & Bailliu et al. (2015) \\
\hline Total capital share in production & $\alpha$ & 0.35 & Iacoviello (2015) \\
\hline Investor's share of capital & $\mu$ & 0.46 & Iacoviello (2015) \\
\hline Housing share & $v$ & 0.04 & Iacoviello (2015) \\
\hline Persistence parameter (productivity shock) & $\rho_{A}$ & 0.908 & Backus et al. (1992) \\
\hline Standard deviation (productivity shock) & $\sigma_{A}$ & 0.0085 & Backus et al. (1992) \\
\hline Correlation between productivity shocks & $\omega_{A}^{i, j}$ & 0.258 & Backus et al. (1992) \\
\hline
\end{tabular}




\subsection{Results}

\subsubsection{International business cycle moments}

In Table 3.4, we report some key business cycle moments for the US economy and cross-country correlations of output, consumption and commercial real estate prices. In columns 3 to 6 , we report the simulated moments from four scenarios (See Table 3.5 for the scenarios' details). Columns 3 and 4 assume homogeneous policies across countries. In column 3 , we assume that the two countries follow tight macroprudential policy across countries, where the LTV ratio is $70 \%$, the capital adequacy ratio is $20 \%$, investors are only allowed borrow up to $1 \%$ of the collateral from banks outside of the country and regulators adjust policy according to equations (3.8) and (3.12) ("active policy"). The impulse responses for this scenario are depicted with a solid blue line. In column 4, we assume that the two countries follow loose macroprudential policy, where the LTV ratio is $90 \%$, the capital adequacy ratio is $10 \%$, investors are allowed borrow up to $30 \%$ of the collateral from banks outside of the country and regulators adopt a passive policy . The impulse responses for this scenario are depicted with a dashed red line.

Columns 5 and 6 assume heterogeneous policies. In column 5, we assume that the domestic country follows a tight "active" macroprudential policy, while the foreign country follows a loose "passive" macroprudential policy. The impulse responses are depicted with a solid black line. In column 6, we assume that the domestic country follows a loose "passive" macroprudential policy, while the foreign country follows a tight "active" macroprudential policy. The impulse responses are depicted with a green line.

We compare the moments predicted by our model under all the scenarios we analyze to the moments of the U.S data to understand how our model fits the data. We also compare our results to those reported for baseline parameterizations in the seminal international RBC paper of Backus, Kehoe and Kydland (1992) and to Iacoviello and Minetti (2006). The results reported for Iacoviello and Minetti (2006) are for the specification where they assume that the share of domestic collateral is exogenous and real estate is only used for collateral, as it is closest to the assumptions made in 
our model. All versions of our model broadly match the salient features of the US business cycle when at least one country has tight "active" macroprudential policies. In these cases, the standard deviations of output, consumption, and investment in our model are of similar magnitudes as those found in the data. Consumption, investment, domestic loans and commercial real estate prices are procyclical in our model as in the data, and the correlations are of similar magnitude. Net exports to GDP are countercyclical in our model as in the data but the correlations in our model are lower. Our model produces a low positive cross-country output correlation, as does Iacoviello and Minetti (2006). The addition of a third agent (banks) reduces cross-country consumption correlation to below $70 \%$. It is still higher than that found in the data as savers, who do not face financing constraints in the model, do most of the consumption in steady state. Both Iacoviello and Minetti (2006) and Backus, Kehoe and Kydland (1992) report a high counterfactual crosscountry consumption correlations. Our model produces a positive correlation in international real estate prices, though it is lower than that found in the data. In the case where the two countries follow loose homogeneous macroprudential policy the volatility of investment and net exports to GDP is too high and resembles the results from the baseline parametrization in Backus, Kehoe and Kydland (1992). They were able to bring these standard deviations closer to the data by introducing a transportation cost. These results show that our model fits the data reasonably well under all the scenarios we are using for experiments in the following section. 
Table 3.4: International business cycle moments

\begin{tabular}{|c|c|c|c|c|c|c|c|}
\hline & & \multicolumn{2}{|c|}{ Homogeneous Policies } & \multicolumn{2}{|c|}{ Heterogeneous Policies } & \multirow{3}{*}{ Backus et al.(1992) } & \multirow{3}{*}{ Iacoviello and Minetti (2006) } \\
\hline & \multirow[b]{2}{*}{ Data } & Scenario 1 & Scenario 2 & Scenario 3 & Scenario 4 & & \\
\hline & & H:\& F:Tight & H \& F: Loose & H: Tight F: Loose & H: Loose F:Tight & & \\
\hline \multicolumn{8}{|c|}{ Standard Deviation } \\
\hline Output & 1.49 & 1.49 & 1.74 & 1.51 & 1.61 & 1.55 & \\
\hline Consumption & 0.87 & 0.69 & 0.76 & 0.68 & 0.75 & 0.62 & \\
\hline Investment & 6.64 & 6.43 & 21.69 & 8.77 & 9.45 & 16.91 & \\
\hline Net Export/GDP & 0.33 & 0.01 & 3.49 & 1.01 & 0.99 & 2.9 & \\
\hline \multicolumn{8}{|c|}{ Correlation with output } \\
\hline Consumption & 0.84 & 0.86 & 0.85 & 0.86 & 0.86 & 0.79 & 0.77 \\
\hline Investment & 0.9 & 0.96 & 0.24 & 0.69 & 0.74 & -0.27 & \\
\hline Net Export/GDP & -0.44 & -0.05 & 0.11 & 0.05 & -0.06 & -0.02 & \\
\hline Domestic loans & 0.23 & 0.11 & 0.45 & 0.12 & 0.40 & na & 0.81 \\
\hline Foreign loans & -0.07 & 0.11 & 0.45 & 0.12 & 0.40 & na & 0.81 \\
\hline Real estate price & 0.4 & 0.37 & 0.49 & 0.37 & 0.48 & na & 0.45 \\
\hline \multicolumn{8}{|c|}{ Cross-Country correlations } \\
\hline Output & 0.51 & 0.06 & -0.07 & 0.04 & 0.04 & -0.18 & 0.16 \\
\hline Consumption & 0.32 & 0.7 & 0.58 & 0.66 & 0.66 & 0.88 & 0.95 \\
\hline Real estate price & 0.5 & 0.12 & 0.09 & 0.12 & 0.12 & na & 0.95 \\
\hline
\end{tabular}

1. The data is for the US and covers the period 1960Q1-2017Q1. With the exception of net exports to output, the data are logged and detrended by the Hodrick-Prescott (1980) filter. The US national account and loan data is obtained from the FRED data base. The domestic loans from domestic banks are Commercial and Industrial Loans, All Commercial Banks. The foreign loans from domestic banks is Commercial and Industrial Loans, Foreign-Related Institutions. The US real estate price index is the Commercial Property Price Index from Green Street Advisors and is available from 1998Q1-2017Q2.

2. The international correlations are reported by Iacoviello and Minetti (2006) in their Table 2. They report the correlation between commercial real estate and Japan real estate (land) prices (all in real terms) for the period 1983Q1 to 2002Q2. We found that the correlation between US and EU commercial real estate for the period 2000Q1 to 2016Q4 to be of similar magnitude.

\subsubsection{Impulse responses under heterogeneous macroprudential policies}

Our main emphasis in this section is to understand what affects the global demand for bank credit by investors and how this demand in turn affects real estate prices and other key variables. As a summary, in Figure 3.1, we present the impulse responses for domestic and foreign global demand for loans following a positive one standard deviation domestic productivity shock in column 1 and a positive one standard deviation domestic borrowing capacity shock in column 2. 
Figure 3.1: Effect of heterogeneous policies on credit build up under high and low cross-border lending
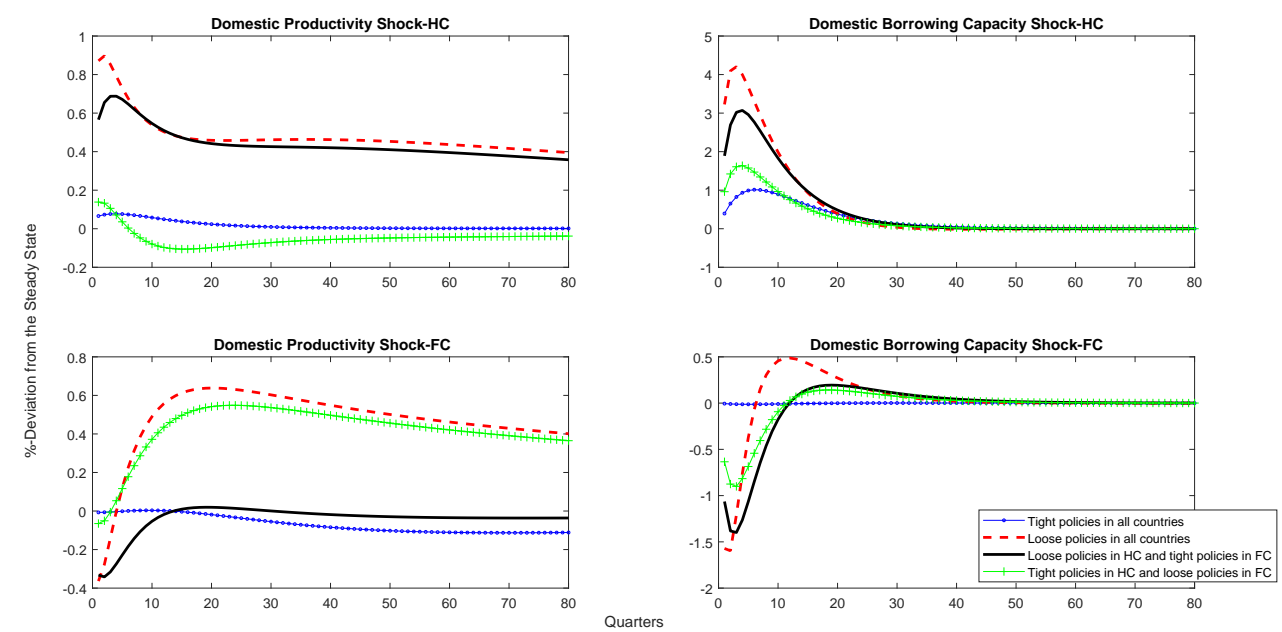

Note: Credit impulse responses following a one standard deviation productivity shock (left column) and a one standard deviation borrowing capacity shock (right column). Blue: Tight policies in all countries. Red: Loose policies in all countries. Green: Tight policies in the home country and loose policies in the foreign country. Black: Loose policies in the home country andtight policies in the foreign country. Home (foreign) country is the first (second) row. $\mathrm{HC}$ is Home Country, FC is Foreign Country.

The global demand for loans by domestic investors increases following a positive domestic productivity shock under each of the four scenarios mentioned in Table 3.5. The shock causes the domestic marginal product of factors of production to increase. As a result, investors borrow more to expand production. As one would expect the demand for credit is much larger when the home country (first row and first column in Figure 3.1) has a loose macroprudential policy. The effects of the productivity shock on credit do spillover to the foreign country as the macroprudential capital requirements increases (second row and first column in Figure 3.1) and the demand for credit by foreign investors is lower than the demand by domestic investors since only the domestic country experiences the shock. Openness to cross-border credit allows domestic investors to borrow more. In both countries, the price of real estate increases (see Figure 3.2) producing a positive correlation as found in the data. Domestic savers demand relatively more housing (see Figure 3.2) when home macroprudential policy is tight because the price of housing does not increase by much. 
Figure 3.2: Effect of heterogeneous policies on financial indicators - Productivity shock
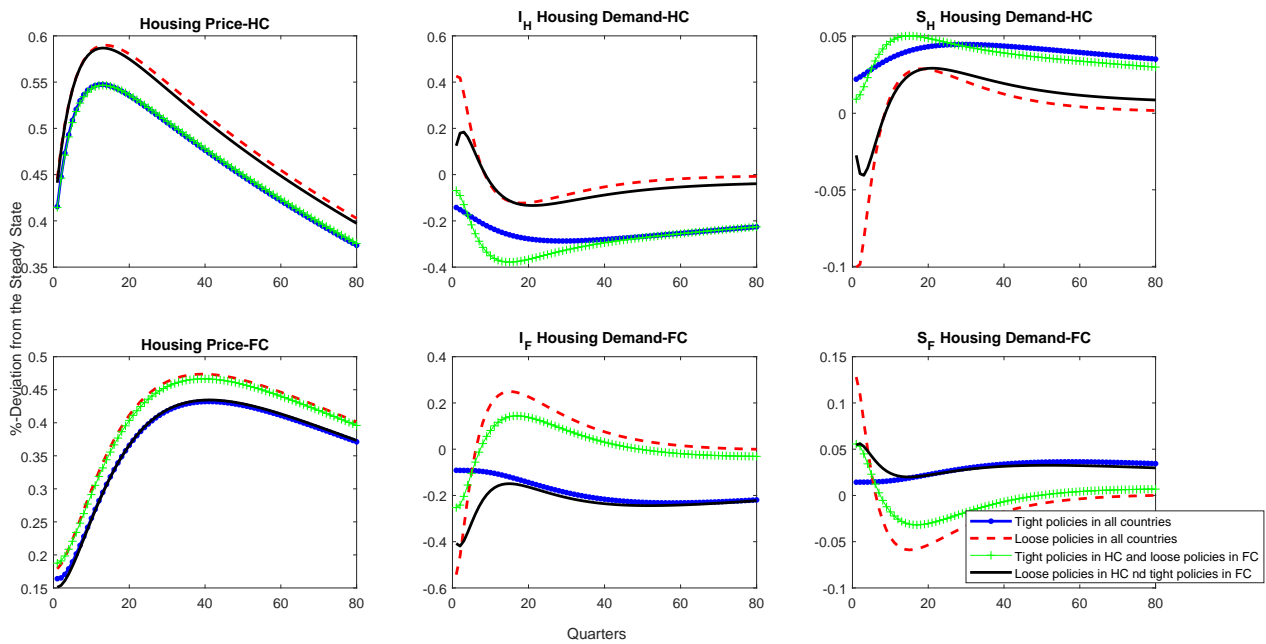

Note: Impulse responses following a one standard deviation technology shock in the home country. Solid blue line: Tight policies in all countries. Solid red line: Loose policies in all countries. Dashed blue line: Tight policies in the home country and loose policies in the foreign country. Dashed red line: Loose policies in the home country and tight policies in the foreign country. Home (foreign) country is the first (second) row. HC is Home Country, FC is Foreign Country.

The global demand for loans by domestic investors increases following a positive domestic borrowing capacity shock, under each of the four scenarios mentioned above (see first row and second column in Figure3.1). ${ }^{24}$ The shock allows domestic investors to borrow more, increasing housing, capital and labor demand to expand production. As one would expect the demand for credit is much larger when the home country has a loose macroprudential policy (depicted with dashed red lines). As a result, the price of domestic real estate increases as domestic investors demand more under these scenarios (see Figure 3.3). As a consequence of these higher real estate prices, domestic savers demand less housing under these scenarios (see Figure 3.3). Interest rates on both deposits and loans rise in both countries. Thus foreign investors, who did not experience a borrowing capacity shock, demand less real estate. This in turn, causes the price of foreign real estate to drop and thus foreign investors demand less global credit (see second row and second column in Figure 3.1). Foreign savers benefit from the drop in their housing price and demand more housing (see Figure 3.3).

\footnotetext{
${ }^{24} \mathrm{~A}$ borrowing capacity shock can lead to an increase of collateral value due to asset market fluctuations.
} 
Figure 3.3: Effect of heterogeneous policies on financial indicators - Borrowing capacity shock
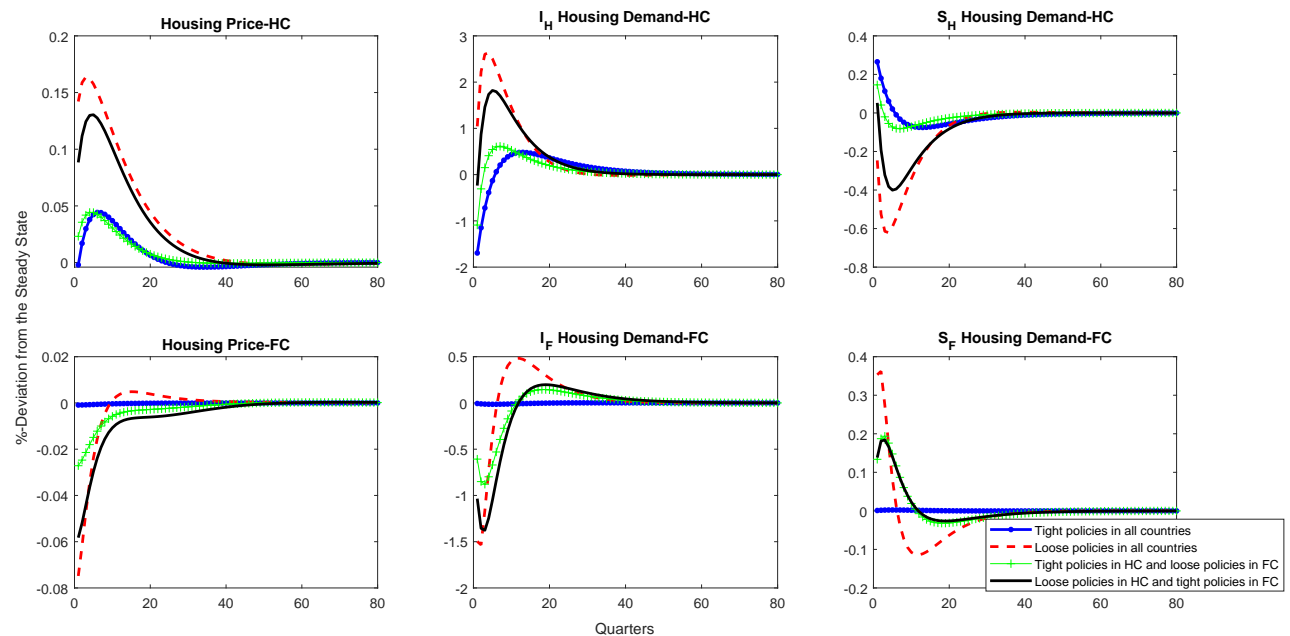

Note: Impulse responses following a one standard deviation borrowing capacity shock in the home country. Solid blue line: Tight policies in all countries. Solid red line: Loose policies in all countries. Dashed blue line: Tight policies in the home country andloose policies in the foreign country. Dashed red line: Loose policies in the home country and tight policies in the foreign country. Home (foreign) country is the first (second) row. HC is Home Country, FC is Foreign Country.

Table 3.5: Parameters for experiments

\begin{tabular}{|c|c|c|c|c|}
\hline & Blue & Red & Green & Black \\
\hline \hline LTV & $\kappa^{H}=\kappa^{F}=.7$ & $\kappa^{H}=\kappa^{F}=.9$ & $\kappa^{H}=.7, \kappa^{F}=.9$ & $\kappa^{H}=.9, \kappa^{F}=.7$ \\
\hline Capital Requirements & $\gamma^{H}=\gamma^{F}=.8$ & $\gamma^{H}=\gamma^{F}=.9$ & $\gamma^{H}=.8, \gamma^{F}=.9$ & $\gamma^{H}=.9, \gamma^{F}=.8$ \\
\hline OPENNESS & $\varepsilon^{H}=\varepsilon^{F}=.99$ & $\varepsilon^{H}=\varepsilon^{F}=.7$ & $\varepsilon^{H}=.99, \varepsilon^{F}=.7$ & $\varepsilon^{H}=.7, \varepsilon^{F}=.99$ \\
\hline ACTIVE MP (Home) & $\phi_{q}^{H}=\phi_{b}^{H}=.5$ & $\phi_{q}^{H}=\phi_{b}^{H}=0$ & $\phi_{q}^{H}=.5, \phi_{b}^{H}=.5$ & $\phi_{q}^{H}=0, \phi_{b}^{H}=0$ \\
\hline ACTIVE MP (Foreign) & $\omega_{q}^{F}=\omega_{b}^{F}=.5$ & $\omega_{q}^{F}=\omega_{b}^{F}=0$ & $\omega_{q}^{F}=0, \omega_{b}^{F}=0$ & $\omega_{q}^{F}=.5, \omega_{b}^{F}=.5$ \\
\hline
\end{tabular}

\subsubsection{Policy Analysis}

The objective of the following experiments is to analyze the impact of heterogeneity of macroprudential policies on credit build up across countries when countries are open to cross-border lending. We look at the dynamic responses of shocks across countries and compare the effect of the policies under high and low openness to cross-border lending exists. As above, we study two types of shocks: a positive productivity shock and a positive borrowing capacity shock. To fully 
understand the effects of each policy, we analyze the effect of heterogeneous LTV ratios separately from the effect of heterogeneous capital requirements. That is, when LTV ratios are considered to be heterogeneous and active (i.e. time-varying), capital requirements are assumed to be homogeneous and passive (i.e. constant). When heterogeneous capital requirements are active, LTV ratios are assumed to be homogeneous and passive.

In the case of heterogeneous LTV ratios, the home country LTV ratio is $70 \%$ and the foreign country LTV ratio is $90 \%$ of the total value of the house. In the case of capital requirements, the requirement is $20 \%$ in the home country and $10 \%$ in the foreign country. We denote high-cross border lending to a situation where $30 \%$ of real estateis pledged as collateral to the foreign bank. Low cross-border lending is fixed to $1 \%$ of the real estate pledged to the foreign bank. For all the experiments, we focus on the effects of these policies on credit build-ups when financial authorities in both countries implement countercyclical macroprudential policies.

\subsubsection{Impulse responses under heterogeneous LTV ratios and homogeneous capital re- quirement regulations}

Figure 3.4: Effect of heterogeneous LTV ratio on credit build up under high and low cross-border lending
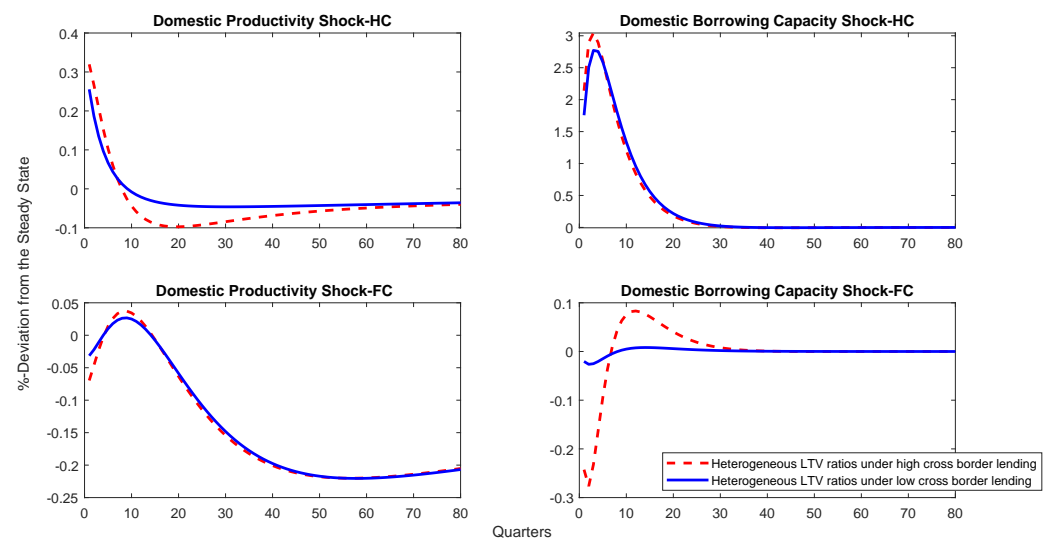

Note: Credit impulse responses following a one standard deviation productivity shock (left column) and a one standard deviation borrowing capacity shock (right column). The blue solid (red dashed) line depicts responses under heterogeneous LTV ratios under low (high) cross-border lending. Home (foreign) country is the first (second) row. HC is Home Country, FC is Foreign Country.

Figure 3.4 illustrates the dynamic responses of investors' global credit demand to a positive 
productivity shock and a positive borrowing capacity shock, originating in the home country, under different degrees of cross-border lending. ${ }^{25}$ For this experiment, LTV ratios are endogenous and capital requirements are constant. ${ }^{26}$ Home (foreign) country is the first (second) row. In this experiment, the home country has tight LTV ratio values, whereas the foreign country has loose LTV ratio values. The solid blue line plots responses of credit build up under low cross-border lending value and the dashed red line depicts responses of the variables to the shocks when home country has access to more foreign credit.

When the home country experiences a positive productivity shock, output and investment increase. ${ }^{27}$ Thus, investors react to this shock by purchasing more housing when they get access to more credit at the international level to have access to credit from all banks. Initially, a higher degree of cross-border lending allows an increase of credit build up for two reasons. First, savers respond to this rise of prices by depositing more of their revenue at the bank. Second, openness to foreign credit encourages investors to borrow more from the foreign bank because the loan interest rate from the foreign bank is lower than the home bank interest rate (See Figure 3.5).

The tight home country LTV ratio reduces credit build up by more under low cross-border credit than under high cross-border credit (The tighter LTV ratio reduces credit build up after eight quarters under high cross-border credit compared to low cross-border credit). ${ }^{28}$ The impact of openness to cross-border credit decays quickly because each country has endogenous LTV ratios which are able to reverse this effect as they become more tight. This reduces the price of housing. Thus, savers reduces savings in favor of housing demand as the housing price decreases. Notice that on the second row, credit demand falls in the foreign country after a positive home country productivity shock. Foreign investors do not have an incentive to borrow because they are not investing in the country experiencing the shock. In addition, despite having a loose LTV ratio, the pledgeability of the housing is lower value than in the home country since we are considering a home country shock only.

\footnotetext{
${ }^{25}$ See Appendix C (Figure C.1 and Figure C.3) for the impulse responses of all variables.

${ }^{26} \mathrm{LTV}$ ratios are active and time-varying.

${ }^{27}$ See Figure 3.2, first column.

${ }^{28}$ The results are similar if home country has loose policy and foreign country has tight policy.
} 
Figure 3.5: Responses of key macroeconomic variables to a domestic productivity shock
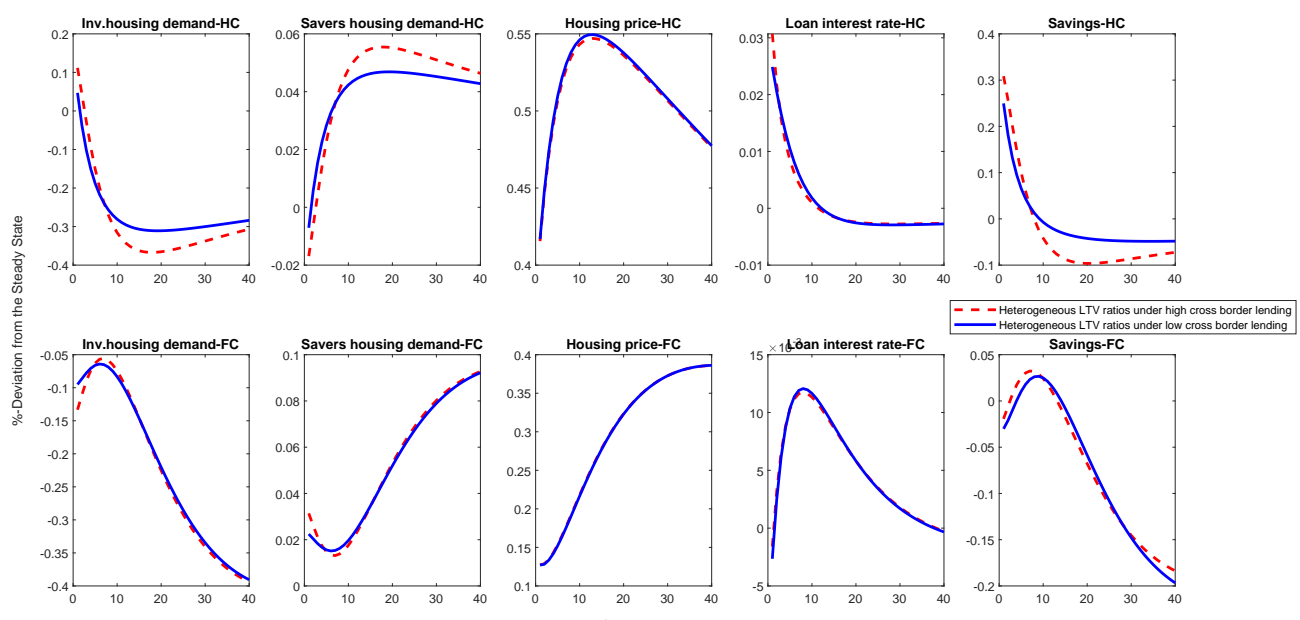

Note: Impulse responses following a one standard deviation technology shock in the home country. The blue solid (red dashed) line depicts responses under heterogeneous LTV ratios under low (high) cross-border lending. Home (foreign) country is the first (second) row. HC is Home Country, FC is Foreign Country.

A positive borrowing capacity shock hitting the home country increases the value of the collateralized house. ${ }^{29}$ Investors housing demand aand housing price increase in the home country (see Figure 3.6). Thus, this shock allows home country investors to acquire more credit and use more deposited funds in all banks. The results confirm our expectations that home investors increase global credit when there is more foreign credit available, which increases transmission of the shock to the foreign country. The decline of foreign investors credit demand is explained by the fact that the foreign country does not experience a borrowing capacity shock and there is a rise of foreign country loan interest rate due to the increase of home investors demand of credit internationally (see Figure 3.6). As expected, a high cross-border lending between countries increases the fluctuation of foreign investors credit demand in both countries. All banks operating in the home country lend more in the home country as home country housing has a higher value under this shock.

\footnotetext{
${ }^{29}$ See Figure 3.2, second column.
} 
Figure 3.6: Responses of key macroeconomic variables to a domestic borrowing capacity shock
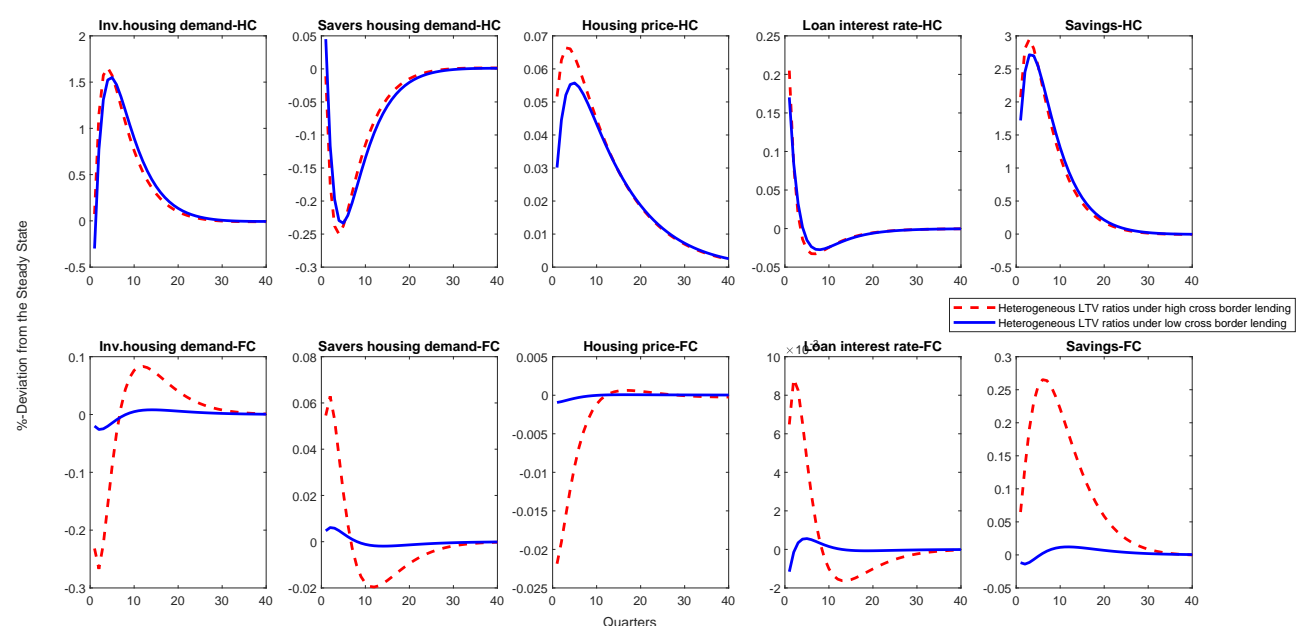

Note: Impulse responses following a one standard deviation borrowing capacity shock in the home country. The blue solid (red dashed) line depicts responses under heterogeneous LTV ratios under low (high) cross-border lending. Home (foreign) country is the first (second) row. HC is Home Country, FC is Foreign Country.

\subsubsection{Impulse responses under homogeneous LTV ratios and heterogeneous capital re- quirement regulations}

Figure 3.7: Effect of heterogeneous capital requirements on credit build up under high and low cross-border lending
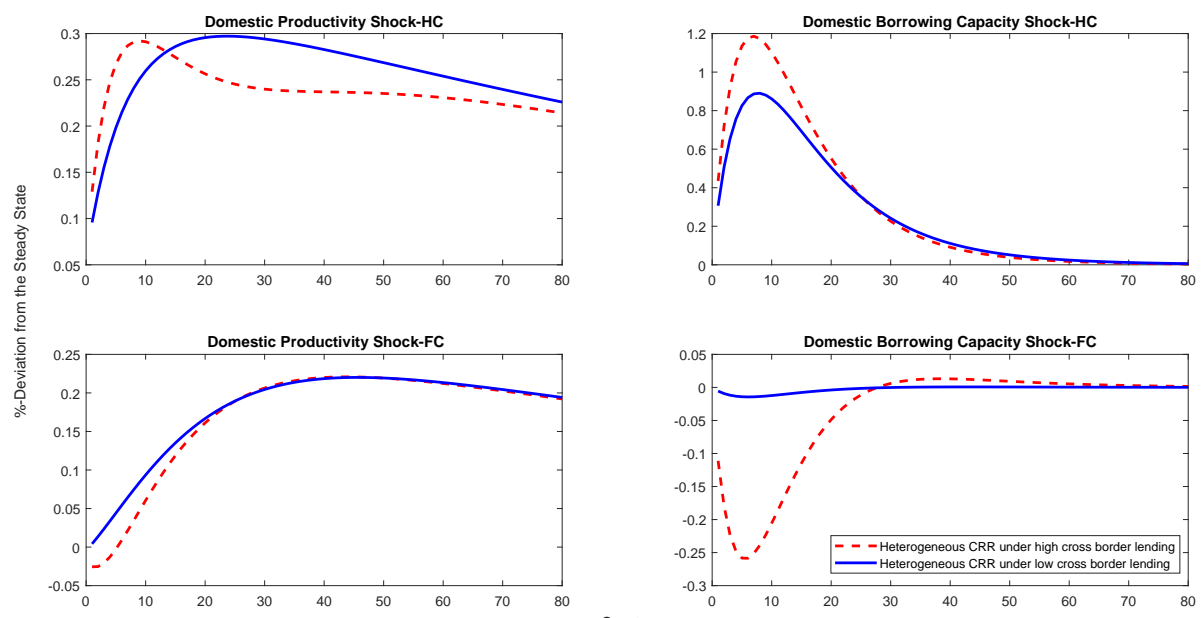

Note : Credit impulse responses following a one standard deviation productivity shock (left column) and a one standard deviation borrowing capacity shock (right column). The blue solid (red dashed) line depicts responses under heterogeneous capital requirements ratios under low (high) cross-border lending. Home (foreign) country is the first (second) row. HC is Home Country, FC is Foreign Country.

Figure 3.7 illustrates the dynamic responses of investors' credit demand to a home country 
productivity shock and borrowing capacity shock under different degrees of cross-border lending. ${ }^{30}$ In this case, capital requirements are active and LTV ratios are passive in both countries. Capital requirements are $20 \%$ in the home country and $10 \%$ in the foreign country. The first row presents responses of the home country international credit build up to the shock and the second row shows the responses of foreign country global credit build up. The blue solid (red dashed) line presents the responses under low (high) cross-border lending.

Despite the implementation of higher capital requirements in the home country compared to the foreign country, we observe that openness to cross-border credit undermines the effectiveness of the policy in reducing credit build up in the home country. For productivity and borrowing capacity shocks, investors' housing demand increases with the availability of more credit (when financial openness is high) because the main incentive for investors to demand housing is to pledge it as a collateral. Credit supply increases internationally. Hence, savers in both countries substitute housing demand with increased savings in banks and consume more in the future (see Figure 3.8). Endogenous domestic capital requirements are not able to control credit build up because of the openness to cross-border credit. ${ }^{31}$ In fact, the share of deposited funds to be considered as capital requirements decrease because they only change with home credit supply.

\footnotetext{
${ }^{30}$ see Appendix C (Figure C.2 and Figure C.4) for the impulse responses of all variables.

${ }^{31}$ Capital requirements adjusting with deviation of domestic banks credit supply from its steady state.
} 
Figure 3.8: Responses of key macroeconomic variables to a domestic productivity shock
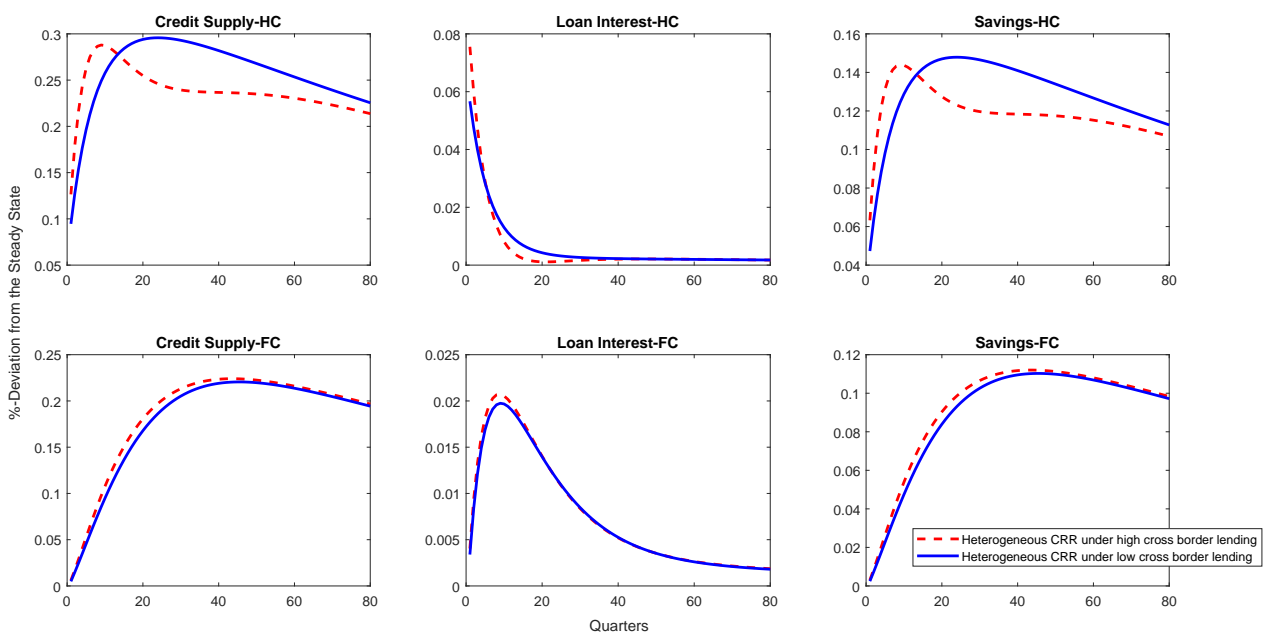

Note : Impulse responses following one standard deviation technology shock in the home country. : The blue solid (red dashed) line depicts responses under heterogeneous capital requirements ratios under low (high) cross-border lending. Home (foreign) country is the first (second) row. HC is Home Country, FC is Foreign Country.

The effects of a positive domestic borrowing capacity shock are transmitted to the foreign country through openness to lending. A rise of home country investors global credit demand reduces credit available to foreign investors (See Figure 3.9). This is because there is a rise of loan interest rate in the foreign country discouraging foreign investors from borrowing at a higher rate. In addition, foreign investors have limited access to global credit in this scenario and do not own a home country house (which is the asset experiencing the shock) as a collateral. Therefore, they do not have the same incentive as domestic investors to increase credit demand. For the productivity shock, the shock effect is transmitted in the foreign country under a low and high degree of openness to cross-border credit. This is due to the fact that there is also a positive correlation between home and foreign country productivity shock. ${ }^{32}$ A productivity shock increases demand of credit to all investors. However, domestic investors, influenced by the shock, initially demand more credit in the foreign banks, which have lower interest rate.

\footnotetext{
${ }^{32}$ We consider a cross country correlation in the productivity shocks as in Backus et al. (1992).
} 
Figure 3.9: Responses of key macroeconomic variables to a domestic borrowing capacity shock
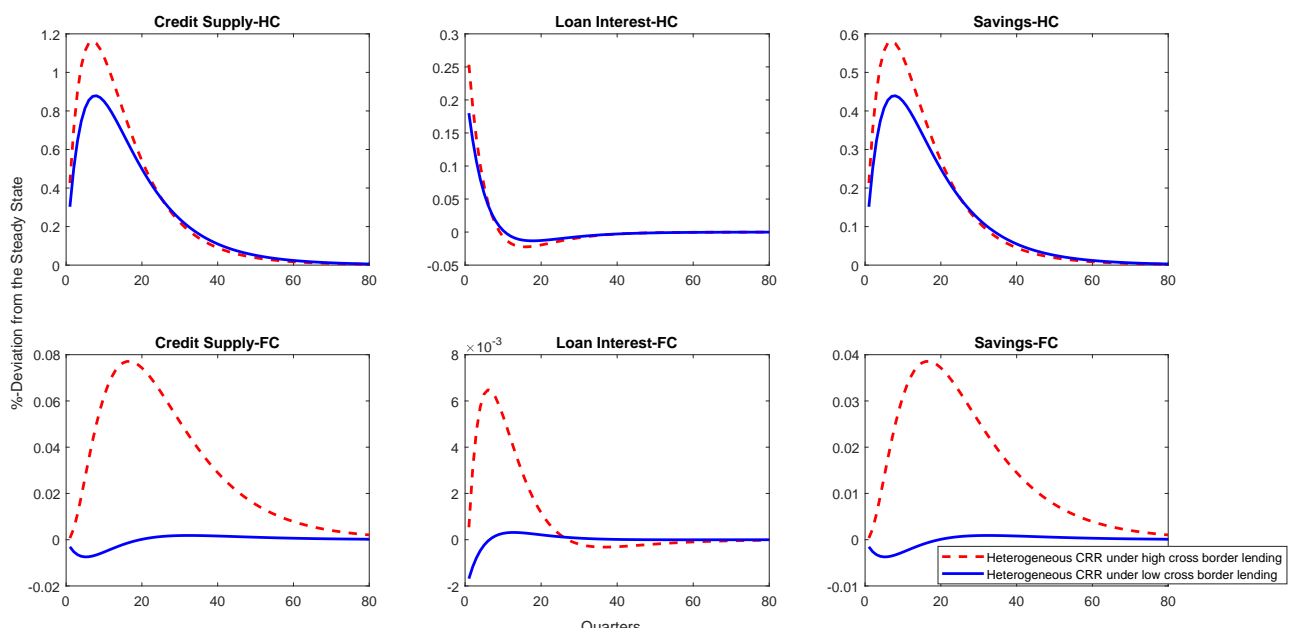

Note : Credit build up impulse responses following a one standard deviation borrowing capacity shock in the home country. : The blue solid (red dashed) line depicts responses under heterogeneous capital requirements ratios under low (high) cross-border lending. Home (foreign) country is the first (second) row. HC is Home Country, FC is Foreign Country.

From the experiments above, our results show that financial regulators can reduce aggregate credit growth by lowering LTV and increasing capital requirements on banks. These findings correspond with the recent empirical studies. For example, Bremus and Fratzscher (2015), IMF (2015a), Ohls et al. (2016), Frost et al. (2016), Berrospide et al. (2016), Damar and Mordel (2016) find that the decline of cross-border lending since the financial crisis is explained by the implementation of macroprudential policies. However, a high cross-border lending reduces the impact of capital requirements on aggregate credit growth. In the following section, we study how financial regulators can diminish this ineffectiveness of macroprudential policies to slow down credit growth due to high cross-border lending. 


\subsubsection{Impulse responses under international coordination of macropruden- tial policies}

Recent literature on the impact of macroprudential policies on international banking activities recommend international coordination of the policies to improve their effectiveness in reducing credit growth. ${ }^{33}$ Rubio (2014b) refers to the coordination of macroprudential policies as centralized macroprudential policy where the policy depends on the domestic and foreign credit growth as oppose to decentralized macroprudential policy where financial authorities determine macroprudential level based on the change of their own country's financial indicators. In this experiment, coordination means that prudential policies should be implemented simultaneously in each country taking into account global credit growth. We follow Rubio (2014b) because the macroprudential policies we are analyzing are the same. Agenor et al. (2017) use a similar idea when they analyze cooperation of advanced and emerging countries' policymakers when implementing macroprudential policy in form of tax. They consider that under cooperative policy, policymakers of different countries choose the optimal tax policy to implement in advanced and emerging ountries, whereas under non cooperative policy policymakers choose the prudential policies to implement in their countries.

In our model, we aim to understand the importance of coordination of macroprudential policies in reducing credit growth. In the scenarios above, we compared heterogeneous LTV ratio and capital requirements under low and high cross-border lending. The experiments results have shown that high cross-border lending reduces the impact of capital requirements under any shock. This is because high cross-border financial activities increase the accessibility to credit through foreign savings and foreign banks operating in the home country. The heterogeneity of LTV ratios across countries was not affected much by the existence of cross-border lending. Therefore, we only focus on the need of coordination of capital requirements in this section.

As in Rubio (2014b), we formulate coordinated macroprudential policies across countries and take into account the deviation of credit supplied by all banks from their steady state values in all

\footnotetext{
${ }^{33}$ See for example Damar and Mordel (2016) and Frost et al. (2016).
} 
countries. The objective of this experiment is to analyze if international coordination of capital requirements can help to reduce credit growth when cross-border lending is high. To evaluate the effect of coordination of macroprudential policies, we compare the behavior of credit growth under coordination and non-coordination of capital requirements, assuming a high degree of cross-border lending. In both countries, the bank capital requirement becomes:

$$
\gamma_{t}^{i}=\gamma^{i}\left(\frac{L_{B, t}^{i}}{L_{B}^{i}}\right)^{-\phi_{b}}\left(\frac{L_{B, t}^{j}}{L_{B}^{j}}\right)^{-\phi_{b}}
$$

Figure 3.10: Cross-border coordination of heterogeneous capital requirements
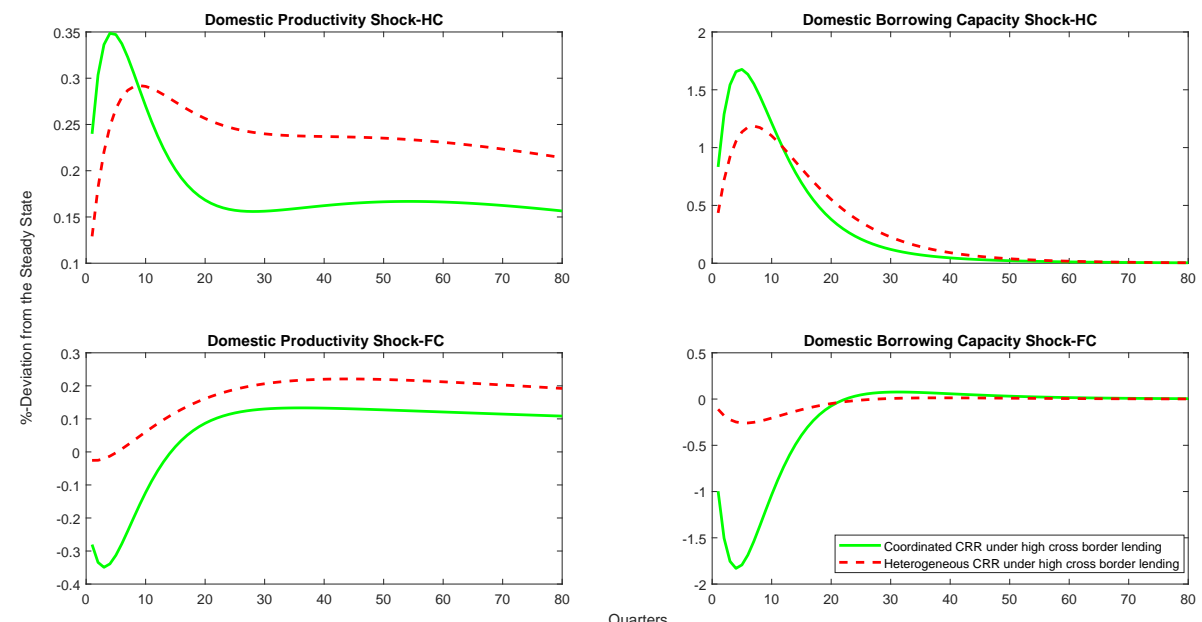

Note: Credit impulse responses following a one standard deviation productivity shock (left column) and a one standard deviation borrowing capacity shock (right column). Dashed red line: Heterogeneous capital requirements under high cross-border lending. Solid green line: Coordinated capital requirements. Home (foreign) country is the first (second) row. HC is Home Country, FC is Foreign Country.

Figure 3.10 compares the dynamic responses of credit demand following a productivity shock and a borrowing capacity shock under coordinated and uncoordinated capital requirements. We introduce a new experiment into the previous panel in section 3.5.4. The new scenario considers coordinated capital requirements across countries under high cross-border lending (It corresponds to the solid green line in Figure 3.4). The dashed red line represents the case of uncoordinated capital requirements under high cross-border lending (Same definition of dashed blue line in all experiments). For the two scenarios, the steady state capital requirements is $10 \%$ in the foreign 
country and $20 \%$ in the home country. LTV ratios are constant and have the same parameter values in both countries. The first (second) row shows the impulse responses of home (foreign) country demand for credit to a onestandard deviation productivity shock and a one standard deviation borrowing capacity shock.

Under a positive productivity shock, coordination of capital requirements across countries causes a faster decrease in the domestic demand for credit after few quarters compared to nocoordination of policy. With coordinated capital requirements, banks retain a higher share of deposited funds by savers. In addition, the foreign loan interest rate is higher under coordinated policies and the share of savings used to supply credit decreases in the home country (see Figure 3.11) which discourages both domestic and foreign investors from borrowing.

Figure 3.11: Responses of key macroeconomic variables to a domestic productivity shock
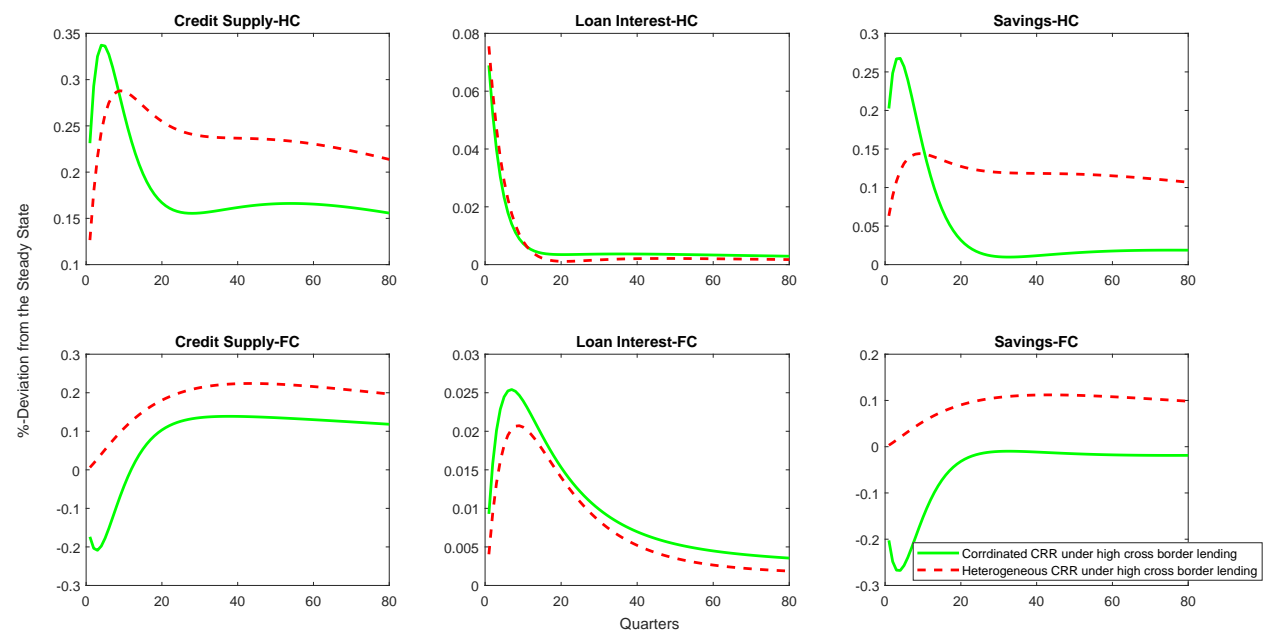

Note: Credit impulse responses following a one standard deviation productivity shock. Dashed red line: Heterogeneous capital requirements under high cross-border lending. Solid green line: Coordinated capital requirements. Home (foreign) country is the first (second) row. HC is Home Country, FC is Foreign Country.

In addition, foreign capital requirements become tighter as they change in response to the increase in the global supply of credit. Under a positive borrowing capacity shock, the magnitude of home credit deviation from the steady state is much higher compared to the productivity shock (a deviation of around $1.7 \%$ under borrowing capacity shock and a deviation of around $0.35 \%$ under a productivity shock). This shock increases the value of the collateral, therefore, international 
coordination adjusting just credit supply cannot be initially effective in reducing global credit demand. However, foreign investors not experiencing the shock reduce credit demand. We notice that coordination of capital requirements does not result in an immediate credit boom mitigation in the domestic country as soon as the shock hits. The inability of coordination of capital requirements to reduce credit growth in the home country experiencing the shock comes from the fact that the change in the level of capital requirements does not affect the value of the house pledged as a collateral. Instead, the change in the level of capital requirements becomes effective as the foreign loan interest rates increases (see Figure 3.12).

Figure 3.12: Responses of key macroeconomic variables to a domestic borrowing capacity shock
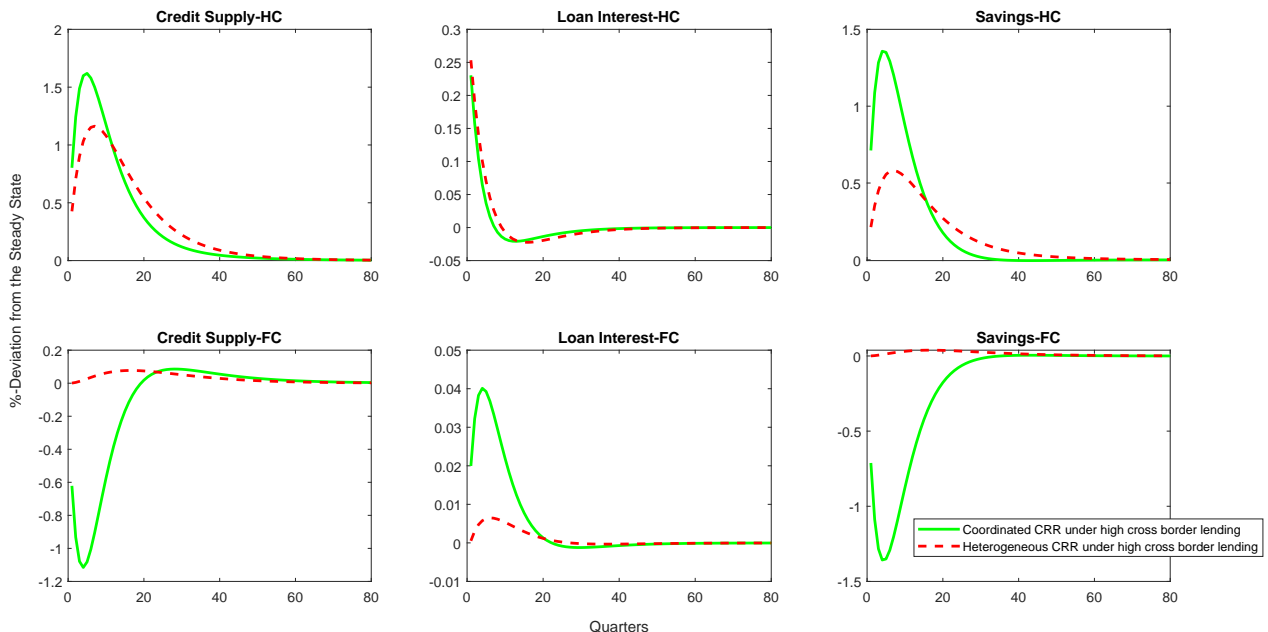

Note: Credit impulse responses following a one standard deviation borrowing capacity shock. Dashed red line: Heterogeneous capital requirements under high cross-border lending. Solid green line: Coordinated capital requirements. Home (foreign) country is the first (second) row. HC is Home Country, FC is Foreign Country.

\subsubsection{Impulse responses under complementarity of macroprudential policy}

In this section, we focus on the role of complementarity of different macroprudential policies. ${ }^{34}$ The recent macroprudential policy database developed by Cerutti (2016) shows that the prudential instruments are not only heterogeneous across countries but also macroprudential policies do not reduce credit supply and the value of collateral simultaneously within a country. In the model, we have the heterogeneous LTV ratios and capital requirements formulated as:

\footnotetext{
${ }^{34}$ Complementarity of policies means that both LTV ratio and capital requirements are both tightened when a countries experience a credit expansion.
} 


$$
\begin{gathered}
\kappa_{t}^{i}=\kappa^{i}\left(\frac{q_{t}^{i}}{q^{i}}\right)^{-\phi_{q}} \\
\gamma_{t}^{i}=\gamma^{i}\left(\frac{L_{B, t}^{i}}{L_{B}^{i}}\right)^{-\phi_{b}}
\end{gathered}
$$

The steady state value of the LTV ratio in the home country $\kappa^{i}$ is fixed at $70 \%$ and $90 \%$ of the value of the house in the home and foreign country, respectively. The steady state value of the capital requirements $\gamma^{i}$ is fixed at $20 \%$ of the loans in the home bank and at $10 \%$ of the loans supplied in the foreign bank. This experiment is different from the previous experiment because we consider that all the policies are active (or endogenous). In this case, we assume that the home country financial regulators impose tight active policies which complement each other within the home country by affecting both the ability to reduce credit demand and supply at the same time. In the foreign country, there are loose active policies. We only evaluate the reactions to production and borrowing capacity shocks when there is high cross-border lending.

Figure 3.13: Complementary policies under high cross border lending
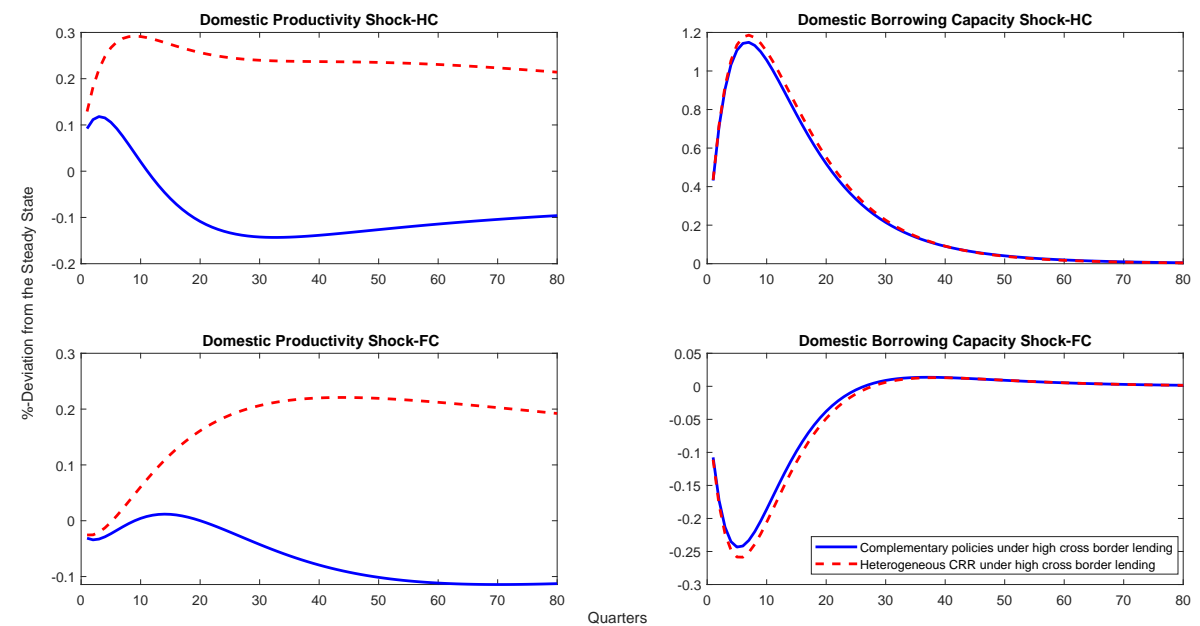

Note: Credit impulse responses following a one standard deviation productivity shock (left column) and a one standard deviation borrowing capacity shock (right column). Dashed red line: Heterogeneous capital requirements under high cross-border lending. Solid blue line: Complementary policies. Home (foreign) country is the first (second) row. HC is Home Country, FC is Foreign Country. 
Figure 3.13 illustrates the dynamic responses of credit build up to all the shocks (productivity shock and borrowing capacity shock) in the domestic country under complementary LTV ratios and capital requirements. The new scenario added to represent the reaction to the shocks of the global credit build up under complementarity of the LTV ratio and capital requirements is the blue solid line. The dashed red line represents the case of heterogeneous capital requirements ratio and high cross-border credit as in section 3.5.4. The first row represents the impulse responses of home country credit demand and the second row represents the impulse responses of foreign country credit demand.

The implementation of tight and endogenous LTV ratio and capital requirements is effective in reducing credit build up in the home country experiencing the productivity shock. In fact the home country LTV ratio and capital requirements respond to the shock by reducing the value of the collateral. Hence, credit supply by all banks decreases. As expected, home bank credit supply decreases more compared to the foreign country because it is required to hold more capital than the foreign bank. The transmission of the shock in the foreign country is minimized by the existence of the two policies because the foreign country housing value also decreases when LTV ratio and capital requirements are endogenous ( see Figure 3.14).

Figure 3.14: Responses of key macroeconomic variables to a domestic productivity shock
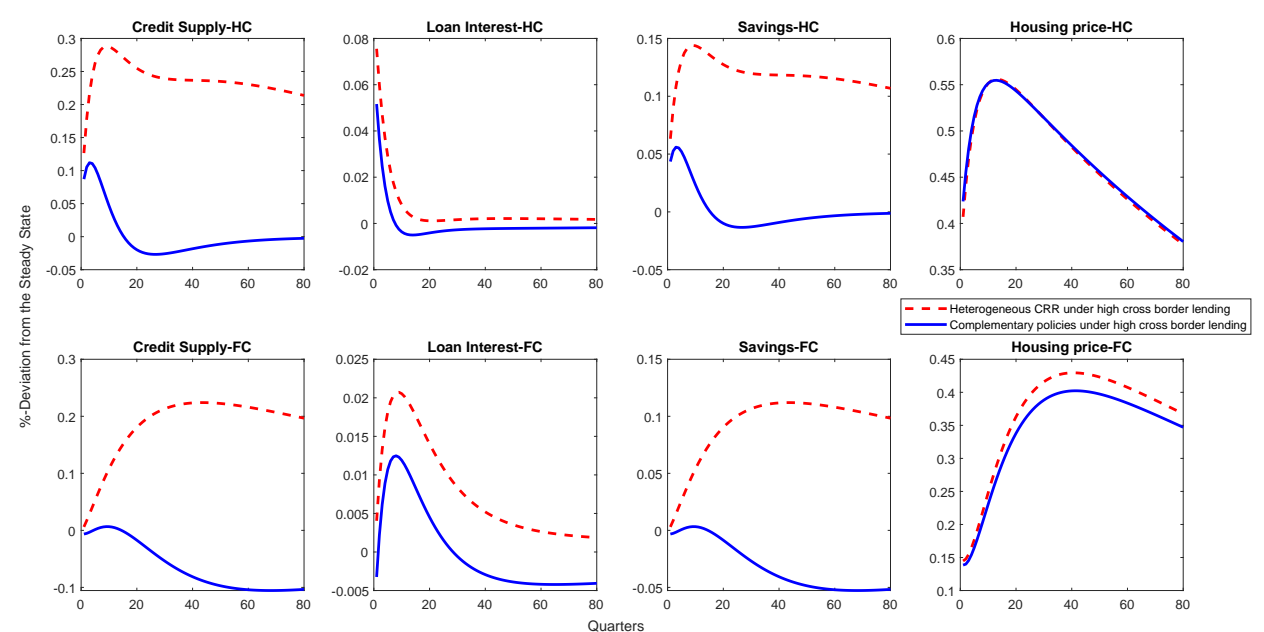

Note: Credit build up impulse responsesfollowing a one standard deviation technology shoc. Dashed red line: Heterogeneous capital requirements under high cross-border lending. Solid blue line: Complementary policies. Home (foreign) country is the first (second) row. HC is Home Country, FC is Foreign Country. 
For a borrowing capacity shock, this experiment shows that having both policies endogenous and tightened reduces slightly the home country credit build up compared to the response of home country credit build up under other scenarios. Although credit demand increases initially due to the rise of investor's housing demand and housing price (see Figure 3.15), it returns to the steady state much quicker than in other scenarios (the case of the dashed red lines). This effectiveness is explained by the existence of the LTV ratio because this shock influences the value of housing. The LTV ratio declines as housing value increases. The foreign country credit is affected in a different manner, where credit demand initially decreases because of the increase in the foreign loan interest rate. Regardless of the shock, the two policies in each country help to reduce the housing price and/or loan interest rate. The collateral is evaluated at a low value and the time varying LTV ratio helps to reduce the increase of the housing price, which reduces the deviation of the housing price from its steady state. As a consequence, housing becomes affordable to the home country savers who use only their revenue to increase housing demand instead of saving.

Figure 3.15: Responses of key macroeconomic variables to a domestic borrowing capacity shock
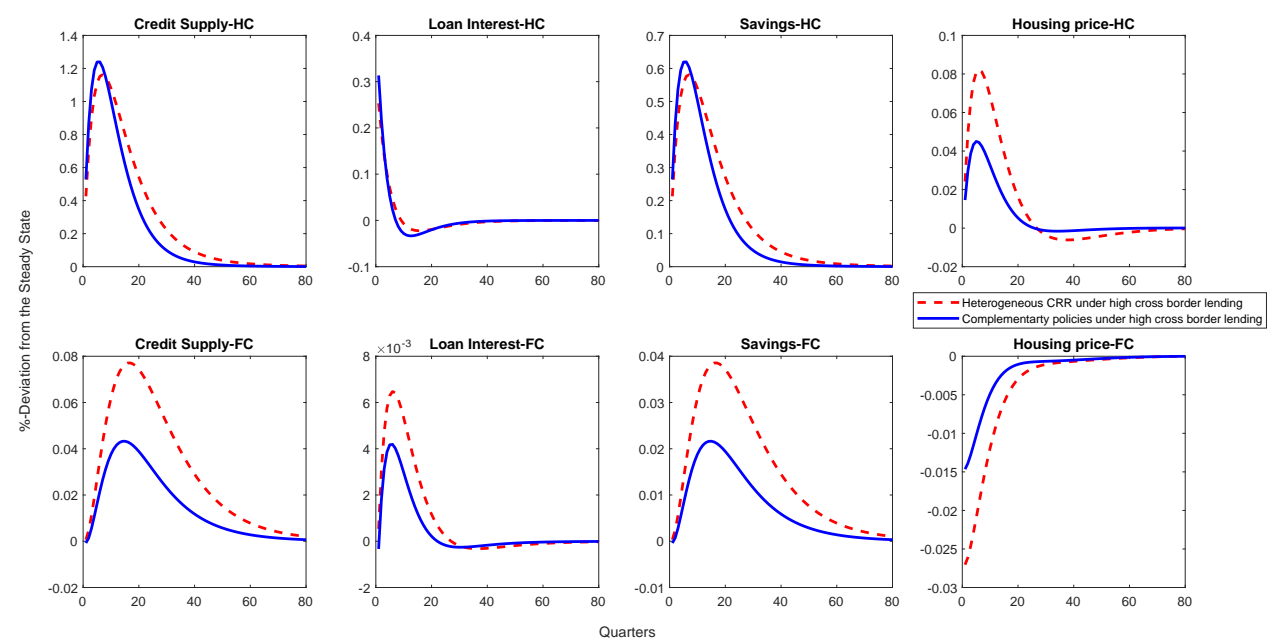

Note: Credit build up impulse responses following a one standard deviation borrowing capacity shock. Dashed red line: Heterogeneous capital requirements under high cross-border lending. Solid blue line: Complementary policies. Home (foreign) country is the first (second) row. HC is Home Country, FC is Foreign Country. 


\subsection{Conclusion}

The aim of the chapter is to analyze the effectiveness of macroprudential policies across countries involved in cross-border banking activities. For the analysis, we consider countercyclical LTV ratios and capital requirement macroprudential policies implemented with the intention of reducing credit buildup. We develop a two-country DSGE model with housing to evaluate the success of macroprudential policies which have been implemented in many countries after the 2007-2008 global financial crisis. To capture the existence of cross-border banking activities, we allow borrowers to demand credit from domestic and foreign banks operating in their country and savers to deposit their funds in domestic and foreign banks as well. The model considers two symmetric countries and we compare the effectiveness of macroprudential policies when there is low access to international lending and when there is high international credit available. We consider two domestic shocks: a technology shock and a borrowing capacity shock.

The results suggest that high cross-border lending influences the credit build up despite the implementation of strict prudential policies. We find that LTV ratios adjust faster than capital requirements when the financial indicator changes. Therefore, they are more effective in reducing credit build up in countries open to cross border lending activities. Capital requirement policies cannot mitigate completely the effects of these shocks when borrowers have access to credit from foreign banks under different regulation policies. In fact, foreign banks with less strict capital requirements increase lending to domestic borrowers through their branches operating in the country. The impact of cross-border lending with heterogeneous LTV ratios is lower than that with heterogeneous capital requirements across countries. The reason is that all banks have to apply the same LTV ratio to borrowers from the same country, whereas the capital requirements applied depend on the bank's country of origin.

Drawing on Reinhardt and Sowerbutts (2015), Houston et al. (2012) and institutions such as the European Systemic Risk Board (ESRB) and the Basel Committee on Banking Supervision, who call for reciprocity and coordination of macroprudential policies, we analyze the extent to which coordination and complementarity of the policies can help to reduce the ineffectiveness of capital 
requirements. We find that international coordination of capital requirements helps to reduce crosscountry propagation of the shock but does not necessary help to reduce the credit boom in the country experiencing the shock in the short run. Our findings suggest that complementarity of LTV ratios and capital requirements within the country is useful in reducing credit boom in the home country. However, it does not reduce the transmission of financial shocks to the financially linked country. The policy implications of macroprudential policies are important and beneficial in terms of managing and controlling credit growth if there is avoidance of the policies by the lenders and borrowers in financially integrated countries. We recommend that policymakers implement complementary policies controling both the borrowers and the lenders in countries open to crossborder lending. 


\section{Chapter 4}

\section{The Impact of Macroprudential Policies on the Transmission of Shocks}

\subsection{Introduction}

This chapter investigates the role of the LTV ratio, as a macroprudential policy, in mitigating the implications of negative financial and productivity shocks transmitted across countries during periods of crisis. We consider that two countries are financially integrated through the existence of global investors who invest in the domestic and foreign pledgeable assets. This chapter differs from Chapter 3, as we focus on the existence of international investors with the ability to pledge collateral from different countries to borrow domestically. In Chapter 3, international financial activities exist as we consider an economic environment where domestic and foreign banks lend to local investors. In addition, the chapter 3 analysis focuses on the role of macroprudential policies on the mitigation of credit build up and the transmission of positive shocks across countries when countries are financially integrated through the existence of global banks subject to different macroprudential policies. There has been ample literature analyzing how shocks are transmitted across countries since the 2007 financial crisis (see for example Devereux and Yetman (2010), Dedola and Lombardo (2012), Trani (2015)). However, the effect of macroprudential policies on 
the transmission channels such as international investment has not received as much attention. The contribution of this chapter to the literature is to analyze how the time-varying LTV ratios ( also known as countercyclical LTV ratios) can reduce the international transmission of shocks across financially integrated countries. A time- varying LTV ratio is a LTV ratio which moves in opposite direction to aggregate economic activity and to financial indicators such as credit growth, asset prices, credit-to-GDP ratio. We follow Bailliu et al. (2015) and Rubio (2016) and set the LTV ratios to vary with the change of credit growth in this chapter. We analyze the extent to which this policy can reduce the severity of a crisis and its transmission across countries. The choice of this prudential tool is based on the fact that we analyze macroprudential policies that directly affect borrowers (international investors). The goal here is to understand how policies, that adjust if there is a change of credit growth, would be helpful in reducing financial instability and fluctuations of key macroeconomic variables across countries, when investors are involved in cross-border investment activities. The chapter differs from the previous chapter in that it considers the existence of global investors in the model, whereas chapter 3 considers the existence of global banks. Our objective in this dissertation is to explore different sources of propagation of shocks across financially integrated countries because global banks and global investors in financial markets play an important role in the propagation of shocks. In addition, banks and investors in general face different type of macroprudential policies.

International financial integration played an important role in the propagation of the 2007 financial crisis. ${ }^{1}$ Prior to 2007 , domestic and foreign financial institutions were heavily invested in the subprime assets. This helped the subprime mortgage crisis to be propagated across countries (Dedola and Lombardo (2012)). The pledgeability of risky assets is considered to be one of the causes of the 2007 financial crisis as the negative financial shock to the pledged assets not only caused default on credit which affected liquidity of both domestic and international lenders but also reduced investors' balance sheet and increased loan losses by banks (Obstfeld and Rogoff (2009)). According to Kollmann et al. (2011), US banks lost around 4\% of annual US GDP and foreign

\footnotetext{
${ }^{1}$ See for example: Claesseness et al. (2010).
} 
loan losses of euro area banks from US represented about 5\% of US GDP between 2007and 2009. In addition to the U.S. expansion of financial cross-border activities, other countries for example EU countries and OECD countries also increased international financial investment in the last two decades. In Figure 4.1, we observe that countries (EU members) which experienced the deepest recession in our sample of countries, also experienced more fluctuations of FDI with more FDI outflows than inflows. Thus, the increase of financial interdependence through FDI amplified the deterioration of economic conditions of all countries engaged in financial linkages and played an important role in the spread of the crisis across countries.

Figure 4.1: FDI and GDP growth
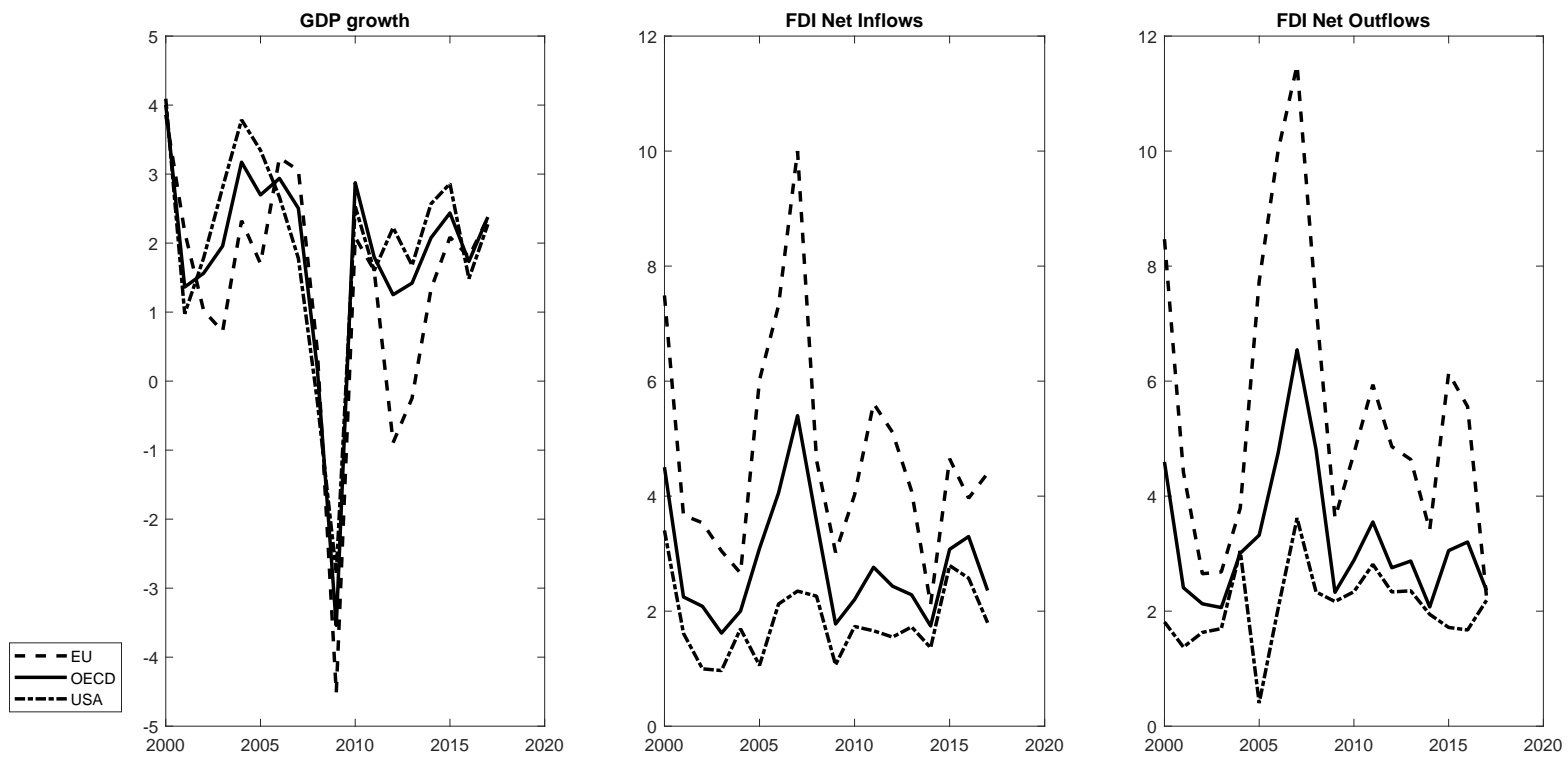

Data Source WDI -World Bank data

Definition FDI refers to direct investment equity flows in an economy. It is the sum of equity capital, reinvestment of earnings, and other long-term capital, and short-term capital as shown in the balance of payments.

GDP is the sum of gross value added by all resident producers in the economy plus any product taxes and minus any subsidies not included in the value of the products.

Research shows that international portfolio holdings helped to reduce the volatility of investment performance and its return in a large number of countries. ${ }^{2}$ Also financial integration presents many advantages as it helps to increase macroeconomic performance through risk sharing and credit availability. However, the propagation of the 2007 financial crisis demonstrated the need to

\footnotetext{
${ }^{2}$ Vermeulen (2011) finds that international portfolio holdings decreased volatility of investment performance between $2 \%$ and $36 \%$ compared to a portfolio consisting only of domestic equity.
} 
prevent and mitigate the negative effects to an economy if there is a future crisis in financially integrated countries. Hence, in this chapter, we focus on cross-border transmission of negative shocks when there exists cross-border equity investment. We examine if the implementation of time varying LTV ratios could be useful in mitigating the propagation of these shocks across countries by lowering fluctuations in investment and production. We consider an economic environment where investors can pledge assets from different countries and evaluate how the LTV ratio can reduce the transmission of shocks across countries. We expect the effects of macroprudential policies at the national level to be different in the international economy for two reasons. First, countries involved in cross-border financial activities experienced shocks at different times which created macroeconomic instability in other countries through financial linkage channels. For example, in the Euro area, countries like Germany, France and Belgium, experienced different shocks than Greece, Portugal, Spain, and Italy. ${ }^{3}$ These can explain the different macroprudential policies employed. ${ }^{4}$ Second, the literature demonstrates that some countries increased cross-border banking activities (see Chapter 2) after the implementation of macroprudential policies because of the differences in banking management and tightness of the policies (see for example: Damar \& Mordel (2016)). Therefore, it is important to understand if in a financially integrated world, the macroprudential policies can be effective in controlling financial and economic stability, despite the existing country-specific differences in these policies. This chapter addresses two important aspects not addressed in the previous chapters. First, the influence of time-varying macroprudential policies on international investors with the ability to pledge domestic and foreign assets; second, the role of macroprudential policies in reducing the transmission of shocks such that the shocks originating from one country are not propagated in other countries with whom they are financially linked with.

In this chapter, we develop a two-country model with international portfolios and time-varying LTV ratios which change with the deviation of credit growth from its steady state. ${ }^{5}$ We assume that borrowers invest in domestic and foreign fixed assets, and pledge them as collateral to receive

\footnotetext{
${ }^{3}$ See for example: Brzoza-Brzezina et al. (2013), Andrés et al. (2010), In’t Veld et al. (2012).

${ }^{4}$ See World Economic Outlook - IMF (2008).

${ }^{5}$ Papers such as Devereux and Yetman (2010) and Trani (2015) have used this framework.
} 
credit, which depend on the value of the assets evaluated. In our experiments, we analyze if policymakers should use time-varying macroprudential policies to minimize the transmission of shocks, as opposed to constant LTV ratios used in Devereux and Yetman (2010). We consider negative productivity and borrowing capacity shocks. We contribute to the the literature studying the transmission of shocks across countries by showing that time varying LTV ratios are useful instruments which can reduce the international transmission of shocks. Trani (2015) finds that the financial crisis is propagated mainly through financial linkages instead of trade linkages across countries. Therefore, the consideration of international financial investment and macroprudential policies targeting financial indicators such as credit growth plays an important role in the analysis.

The results of this analysis show that time-varying LTV ratios reduce the fluctuations of key macroeconomic variables such as output, credit demand, and asset prices when a country experiences negative productivity or financial shocks. When financially integrated countries implement time-varying LTV ratios, there is less transmission of negative shocks across countries compared to when LTV ratios are constant. This is because time varying LTV ratios increase the collateral value when a country experiences a negative shock giving investors ability to borrow and continue production even during a period of economic slowdown.

The rest of the chapter is organized as follows. The next section contains a review of the relevant literature. Section 3 describes the model. Section 4 gives details about the calibration of the model. We analyze the reaction of key variables to the implementation of macroprudential policies in Section 5. Section 6 presents a welfare analysis and the final section concludes the chapter.

\subsection{Related Literature}

This analysis contributes to the set of papers studying the relation of international asset diversification and transmission of shocks across countries. In our model, we introduce the existence of financial linkages across countries which allows us to analyze the role of the financial sector in 
the propagation of a financial crisis. Papers such as Devereux and Yetman (2010), Dedola and Lombardo (2012), Devereux and Yu (2014) and Trani (2015) demonstrate the role of international portfolio choice in the transmission of shocks across countries. This analysis contributes to this literature by investigating how an "active LTV ratio" can minimize this transmission of shocks across countries. Devereux and Yetman (2010) focus on the impact of productivity shocks on international portfolio choice and assume that investors issue debt by pledging domestic and foreign equities evaluated homogeneously. The domestic and foreign equities are subject to a constant and equal LTV ratio. They find that when investors' borrowing constraints are binding and when there is investments in international bond and equity market, a productivity shock in one country is transmitted to other financially linked countries. ${ }^{6}$ Kollman et al. (2011) study which shocks were responsible for the 2007 global financial crisis. They explain the transmission of the U.S. financial crisis to the Euro Area using a two-country business cycle model with a global bank subject to capital restrictions. They consider international banking activities to be the main source of transmission of shocks across countries. They find that large loan default shocks in the US. financial market were the main reason why a financial crisis was transmitted to all financially linked countries. Kollman et al. (2011) is related to our analysis as we consider financial interdependence across countries. ${ }^{7}$ In our study, we include an international equity market as in Devereux and Yetman (2010). Dedola and Lombardo (2012) demonstrate that when investors hold domestic and international capital, the propagation of shocks across countries increases as financial integration and financial frictions lead to a rise of borrowing costs and credit spread sharing across countries when there is a crisis in one integrated country.

Devereux and Yu (2014) demonstrate that endogenous international portfolio choice explains the transmission of shocks in a model with an occasionally binding collateral constraint and an integrated equity market. Their analysis consists of comparing three types of financial integration regimes: financial autarky, bond market integration and equity market integration. They find that

\footnotetext{
${ }^{6}$ The introduction of a financial sector and financial linkages in the model helps to explain the magnitude of the co-movement of financial and real variables across countries during the 2007 financial crisis.

${ }^{7}$ Kollman et al. (2011) model is related to chapter 3 as it also considers the existence of banks operating internationally.
} 
financial market integration is associated with the transmission of shocks across countries as it encourages investors to take risk by increasing international investment and borrowing capacity, and by reducing consumption risk through portfolio diversification. Devereux and Yu (2014) is related to the model developed in this chapter because we take into account the existence of an integrated equity market across two countries. Their model differs from our model (and Devereux and Yetman (2010)) since they introduce a banking sector which facilitates investment in the two countries and an occasionally binding collateral constraint based on the state of the economy. In addition, we have a binding collateral constraint and time varying LTV ratios in our model. Trani's (2015) analysis differs from Devereux and Yetman's (2010) as he also explores the impact of financial shocks in addition to productivity shocks. He evaluates how asset pledgeability shocks (financial shocks) are transmitted across countries when investors are allowed to pledge domestic and foreign assets. His results show that international asset pledgeability (i.e. the international portfolio choice) influences the international transmission of shocks across countries. He demonstrates that the occurrence of a negative pledgeability shock in one country forces all investors, local and foreign, to deleverage, which causes the rise of risks premiums in all countries. Perri and Quadrini (2017) use a two-country model with financial frictions and symmetric countries to demonstrate how international financial integration influences the magnitude and probability of crises. They introduce financial integration by assuming that investors, who are the owners of firms, are able to purchase shares of domestic and foreign firms and to borrow in the global bond market. They also assume that each country could experience country-specific credit shocks. They show that a negative credit shock in one country induces a shortage of liquidity in all countries and explains the co-movement of key financial variables across countries. Their objective is to understand the role of financial globalization in contributing to the propagation of shocks. In this chapter, we complement this literature by assessing the role of macroprudential policies in the form of time-varying LTV ratios implemented in each country. These policies are designed to mitigate the international transmission of shocks given our assumption that investments in the global equity market are the channel through which crises are transmitted. 
This chapter also relates to the literature evaluating how the implementation of macroprudential policies can help to reduce the possibility and the magnitude of financial crises in an international context. Jeanne (2013) demonstrates that, for domestic macroprudential policies to be effective, countries involved in cross-country financial activities need to implement controls on capital inflows. He uses a Pigouvian tax on domestic borrowing as a prudential regulation tool and a tax on external borrowing as capital control in a small open economy model. ${ }^{8}$ Unlike Jeanne (2013), we consider that countries involved in cross-border financial activities have time-varying LTV ratio prudential policies in an international macroeconomic model with two similar sized countries. Bengui (2014) assesses how macroprudential policies affect the transmission of liquidity shocks across countries using a multi-country model of liquidity demand. ${ }^{9}$ The focus of his study is on international coordination of macroprudential policies in the form of liquidity standards to reduce transmission of shocks. ${ }^{10} \mathrm{He}$ finds that setting prudential policies reduces the impact of liquidity shocks. However, cooperation from national regulators is necessary to reduce the international spillover effect of macroprudential policies, and gives financial institutions the ability to continue providing credit when a crisis occurs. Unlike Bengui (2014), we focus on the propagation of productivity and financial shocks by analyzing the role of different types of macroprudential policies. Our model set up allows us to understand how macroprudential policies in the form of time varying LTV ratios help to reduce the transmission of financial shocks across countries and how the policies affect all economic agents. In this literature, Rubio (2014) analyzes the importance of implementing homogeneous prudential tools in the housing sector of Euro area countries. She finds that homogeneity of LTV ratios is beneficial when the LTV ratios are high. We differ from her analysis as we consider international financial activities introduced in our model via investment in international equity market. In Rubio (2016), she finds that homogeneous LTV ratios in the housing market could improve welfare of all Euro area countries. Rubio (2016) differs from

\footnotetext{
${ }^{8} \mathrm{~A}$ Pigouvian tax is a tax based on a measure of systemic risk externalities. It can force a systemically important financial institution to internalize the systemic risk it creates (De Nicolo et al. (2012)).

${ }^{9}$ The liquidity shock affects the demand for liquidity which differs from the financial shocks affecting the value of collateral, that we use in our model.

${ }^{10}$ Also known as liquidity ratios consists of high-quality liquid asets set aside by lenders to be used during periods of stress.
} 
Rubio (2014a) as she has time varying macroprudential policies. She focuses on the importance of the implementation of Spain's homogeneous LTV ratios, which reflect the Euro area's policies. We differ from Rubio's papers as we focus on the global equity market and allow cross-country investment in the equity market. Kara's (2016) study is close to our analysis as he assesses the impact of macroprudential policies with international investors using a game theoretic approach. However, in Kara's (2016) model, there is a banking sector and the prudential policies are capital adequacy requirements imposed in the banking sector, whereas we evaluate LTV ratios imposed on borrowers. ${ }^{11}$ Besides, Kara (2016) considers that countries are asymmetric as they differ in terms on productive technologies and have different populations involved in global financial investments.

Papers such as Rabanal and Quint (2013), Mendicino and Punzi (2014) and Brzoza-Brezina et al. (2015) study the impact of macroprudential policies at the international level. However, they focus on the interaction of monetary and macroprudential policies. Rabanal and Quint (2013) analyze how a mix of monetary and macroprudential policies can be useful in reducing macroeconomic fluctuations in a two-country model with domestic and international financial intermediaries operating in the countries. Brzoza-Brezina et al. (2015) study the interaction of LTV ratios and capital requirements with monetary policies in the Euro area. Mendicino and Punzi (2014) address the question related to global financial stability in a two-country model where domestic and foreign countries experience a capital inflow preference shock, which increases domestic consumption, housing investment and housing price. The main conclusion is that monetary authorities should take into account macroprudential policies to ensure global financial stability. Although we have the same goal of analyzing the importance of macroprudential policies in countries open to cross-border financial activities, we do not consider the role of monetary policy.

\footnotetext{
${ }^{11}$ In our model, it is appropriate to use LTV ratios imposed on borrowers as we consider the existence of international investors ( who are the borrowers).
} 


\subsection{Model}

The theoretical framework comprises of two countries (home country $i$ and foreign country $j$ ) with two types of infinitely lived agents, savers and investors. In each country, there are $n$ investors and $1-n$ savers. Investors choose how much to consume. They also participate in the two countries' production by purchasing equity claims in the production firm in both countries so as to maximize profit and diversify their investment. Savers consume a part of their revenue, produce a domestic good, and purchase bonds from domestic and foreign investors where they get a return from holding the bonds every period. For simplicity, all agents supply labor inelastically and each worker receives a wage. To differentiate the two type of agents in the model, we consider that savers are more patient than investors. Investors of each country invest internationally in the equity markets and use the purchased fixed assets in the firm's production. As investors are assumed to be impatient compared to savers, they issue bonds to receive credit. Each period, investors are constrained in their borrowing to a fraction of their equity holdings used as a collateral. The investors' borrowing constraint is assumed to be always binding. Our model is close to Trani (2015) and Devereux and Yetman (2010) who assume that investors issue bonds in an international debt and equity markets. We differ from these two papers in a couple of ways. First, we introduce time varying LTV ratios in the model. Second, we consider an exogenous portfolio choice with a high degree of home equity bias. Coeurdacier et al. (2010) demonstrate that equity home investment is biased in OECD countries.

\section{Investors}

A representative investor in country $i$ maximizes expected utility from consumption by choosing, $C_{I, t}^{i}$, the consumption of the tradable good, $B_{I, t}^{i}$ the loan an investor receives from issuing bonds to domestic and foreign savers, and the amount fixed assets to hold, $K_{t}^{i i}$ and $K_{t}^{i j}$ representing domestic and foreign investment. ${ }^{12}$ The utility function is given by

\footnotetext{
${ }^{12}$ First superscript denotes the investor's country of origin and the second denotes the country of investment.
} 


$$
E_{0} \sum_{t=0}^{\infty} \beta_{I}\left(C_{I, t}^{i}\right) \frac{C_{I, t}^{i(1-\sigma)}}{1-\sigma}
$$

where $E_{0}$ is the expectation operator, $\beta_{I}$ is an endogenous investor's discount factor that is a function of consumption and $\sigma$ is the coefficient of relative risk aversion. The investor's budget constraint is:

$$
\begin{gathered}
C_{I, t}^{i}+q_{t}^{i} K_{I, t}^{i i}+q_{t}^{j} K_{I, t}^{i j}+R_{B, t-1} B_{I, t-1}^{i}= \\
W_{t}^{i}+B_{I, t}^{i}+\left(R_{K, t}^{i}+q_{t}^{i}\right) K_{I, t-1}^{i i}+\left(R_{K, t}^{j}+q_{t}^{j}\right) K_{I, t-1}^{i j}
\end{gathered}
$$

Investors work in the firm and receive a real wage $W_{t}^{i}$ from supplying labor . Labour is supplied inelastically (and normalized to 1). Investors sell bonds in order to invest in the equity market. They receive returns $R_{K, t}^{i}$ and $R_{K, t}^{j}$ on domestic and foreign capital investments, respectively. They use the revenue received to consume, accumulate domestic and foreign fixed assets at prices $q_{t}^{i}$ and $q_{t}^{j}$, respectively, , and pay back the loans with interest $R_{B, t-1} B_{I, t-1}^{i}$ due in period $t . R_{B, t}$ is the real gross interest rate. Each investor pledges the equity claims as a collateral to obtain loans domestically. The borrowing is limited to a fraction $\kappa_{t}^{i}$ and $\kappa_{t}^{j}$ of asset holdings' in the domestic and foreign country, respectively. These fractions are the time-varying LTV ratios determined by macroprudential policy regulators. Domestic and foreign assets are subject to a borrowing capacity shock $\gamma_{t}^{i}$ and $\gamma_{t}^{j}$, respectively. The borrowing constraint is formulated as follows:

$$
B_{I, t}^{i} \leq \gamma_{t}^{i} \kappa_{t}^{i} q_{t}^{i} K_{I, t}^{i i}+\gamma_{t}^{j} \kappa_{t}^{j} q_{t}^{j} K_{I, t}^{i j}
$$

The borrowing capacity shock, which is a general financial shock, capturing the change of collateral value follows an $\mathrm{AR}(1)$ process: ${ }^{13}$

\footnotetext{
${ }^{13}$ See Trani (2015) and Perri and Quadrini (2017).
} 


$$
\log \left(\gamma_{t}^{i}\right)=\rho_{\gamma} \log \left(\gamma_{t-1}^{i}\right)+v_{\gamma, t}^{i}
$$

where $\rho_{\gamma}$ is the parameter capturing the persistence of the borrowing capacity shock and $v_{\gamma, t}^{i} \sim$ iid $\left(0, \sigma_{\gamma}^{2}\right)$. As in Clerc et al. (2014), Rubio (2016), and Bailliu et al. (2015), we consider that the macroprudential policies are adjusted to reflect changes in the rate of growth in credit. Hence, The LTV ratios are formulated as follows:

$$
\begin{gathered}
\kappa_{t}^{i}=\bar{\kappa}^{i}\left(\frac{B_{I, t}^{i}}{B_{I}^{i}}\right)^{-\phi_{b}} \\
\kappa_{t}^{j}=\bar{\kappa}^{j}\left(\frac{B_{I, t}^{j}}{B_{I}^{j}}\right)^{-\phi_{b}}
\end{gathered}
$$

where $\bar{\kappa}^{i}$ and $\bar{\kappa}^{j}$ are the steady state values of the LTV ratio and $\frac{B_{I, t}^{i}}{B_{I}^{i}}$ represents the deviation of credit in country $i$ from its steady state value. The parameter $\phi_{b}$ captures the responsiveness of the LTV ratio to changes in credit. The parameter values are the same in the two countries because we assume symmetry.

\section{Savers}

A representative saver maximizes the expected discounted lifetime utility by choosing consumption $C_{S, t}^{i}$, fixed asset investment $K_{S, t}^{i}$ and debt from investors $B_{S, t}^{i}$.

$$
E_{0} \sum_{t=0}^{\infty} \beta_{S}\left(C_{S, t}^{i}\right)\left(\frac{C_{S, t}^{i(1-\sigma)}}{1-\sigma}\right)
$$

where $\beta_{S}\left(C_{S, t}^{i}\right)$ is the endogenous discount factor defined the same way as for investors.. To differentiate the two types of economic agents in this model, it is assumed that savers are more patient than investors, this assumption holds if : $\beta_{S}\left(C_{S}^{i}\right)>\beta_{I}\left(C_{I}^{i}\right)$. The representative saver in country $i$ faces the following budget constraint : 


$$
C_{S, t}^{i}+B_{S, t}^{i}+q_{t}^{i} K_{S, t}^{i}=W_{t}^{i}+R_{B, t-1} B_{S, t-1}^{i}+q_{t}^{i} K_{S, t-1}^{i}+G\left(K_{S, t-1}^{i}\right)
$$

As in Devereux and Yetman (2010), we assume that $K_{S, t}^{i}$ is used for the production of a non traded good (backyard production) less efficiently than the final good.

$$
G\left(K_{S, t-1}^{i}\right)=Z^{i}\left(K_{S, t-1}^{i}\right)^{\omega}
$$

where $Z^{i}$ is the productivity coefficient and $\omega$ is the capital share in the home production. ${ }^{14}$ The home good is substitutable for the final good.

\section{Firm's production}

Firms operate under perfect competition and are assumed to maximize their profits. Production uses labor supplied inelastically and aggregate predetermined fixed assets $K_{t}^{i}$. Domestic and foreign investors hold fixed assets used in the firm's production from country $i$. The production function is a Cobb-Douglas specified as follows:

$$
Y_{t}^{i}=A_{t}^{i} F\left(L_{t}^{i}, K_{I, t-1}^{i}\right)=A_{t}^{i}\left(K_{I, t-1}^{i}\right)^{\alpha}
$$

With $^{15}$

$$
K_{I, t-1}^{i}=\left(K_{I, t-1}^{i i}\right)^{\zeta}\left(K_{I, t-1}^{j i}\right)^{1-\zeta}
$$

where $0<\alpha<1$ is the aggregate capital share with domestic investors holding a share $\zeta$ of $\alpha$. There is home biasedness as domestic investors hold a higher share of the asset in their own country. ${ }^{16}$ Coeurdacier et al (2010) and Punzi and Rabitsch (2015) also consider the existence of het-

\footnotetext{
${ }^{14}$ As in Kiyotaki and Moore (1997), savers' production is introduced to differentiate the role and ability of different economic agents in production of goods.

${ }^{15}$ The first subscript is where the fixed asset is consumed and the second is where it is produced.

${ }^{16}$ In the foreign country, foreign investors hold a higher share of the foreign assets.
} 
erogeneous investors holding exogenous share of capital). The total factor productivity shock $A_{t}^{i}$ follows an AR (1) process:

$$
\log \left(A_{t}^{i}\right)=\rho_{A} \log \left(A_{t-1}^{i}\right)+v_{A, t}^{i}
$$

where $\rho_{A}$ is the parameter capturing the persistence of the productivity shock and $v_{A, t}^{i} \sim \operatorname{iid}\left(0, \sigma_{A}^{2}\right)$.

\subsubsection{Market clearing conditions}

All markets clear in equilibrium. The equilibrium in the assets market is fixed in country $i$ :

$$
n K_{I, t}^{i i}+n K_{I, t}^{j i}+(1-n) K_{S, t}^{i}=1
$$

and $n$ is the number of investors

The world bond market clears as:

$$
n\left(B_{I, t}^{i}+B_{I, t}^{j}\right)+(1-n)\left(B_{S, t}^{i}+B_{S, t}^{j}\right)=0
$$

The world resource constraint is given by:

$$
n C_{I, t}^{i}+n C_{I, t}^{j}+(1-n)\left[C_{S, t}^{i}-G\left(K_{S, t-1}^{i}\right)\right]+(1-n)\left[C_{S, t}^{i}-G\left(K_{S, t-1}^{j}\right)\right]=Y_{t}^{i}+Y_{t}^{j}
$$

The aggregate consumption is country $i$ is determined as follows: $n C_{I, t}^{i}+(1-n)\left[C_{S, t}^{i}-G\left(K_{S, t-1}^{i}\right)\right]$.

\subsubsection{Solving the model}

\section{Investor's first order conditions}

We solve the investors problem using the Lagrangian multipliers method, since investors have a budget and binding borrowing constraints. In what follows below $\lambda_{t}^{I}$ and $\mu_{t}^{i}$ represent the Lagrangian multipliers on the budget constraint and the borrowing constraint respectively. Investors 
choose $C_{I, t}^{i}, K_{t}^{i i}, K_{t}^{i j}, B_{I, t}^{i}$ to maximize discounted lifetime utility subject to the budget and borrowing constraints. The Lagrangian is:

$$
\begin{aligned}
& L_{I}=E_{0} \sum_{t=0}^{\infty} \beta_{I}\left(C_{I, t}^{i}\right) \frac{C_{I, t}^{i(1-\sigma)}}{1-\sigma} \\
& +\lambda_{t}^{I}\left[W_{t}^{i}+B_{I, t}^{i}+\left(R_{K, t}^{i}+q_{t}^{i}\right) K_{I, t-1}^{i i}+\left(R_{K, t}^{j}+q_{t}^{j}\right) K_{I, t-1}^{i j}-\left(C_{I, t}^{i}+q_{t}^{i} K_{I, t}^{i i}+q_{t}^{j} K_{I, t}^{i j}+R_{B, t-1} B_{I, t-1}^{i}\right)\right] \\
& +\mu_{t}^{i}\left[\gamma_{t}^{i} \kappa_{t}^{i} q_{t}^{i} K_{I, t}^{i i}+\gamma_{t}^{j} \kappa_{t}^{j} q_{t}^{j} K_{I, t}^{i j}-B_{I, t}^{i}\right]
\end{aligned}
$$

Maximization of the investor's utility function subject to the budget and borrowing constraints gives the following efficiency equations:

$$
\begin{gathered}
C_{I, t}^{i(-\sigma)}=E_{t}\left[\beta_{I}\left(C_{I, t}^{i}\right) C_{I, t+1}^{i(-\sigma)}\left(\frac{\left(R_{K, t+1}^{i}+q_{t+1}^{i}\right)}{q_{t}^{i}}\right)\right]+\mu_{t}^{i} \gamma_{t}^{i} \kappa_{t}^{i} \\
C_{I, t}^{i(-\sigma)}=E_{t}\left[\beta_{I}\left(C_{I, t}^{i}\right) C_{I, t+1}^{i(-\sigma)}\left(\frac{\left(R_{K, t+1}^{j}+q_{t+1}^{j}\right)}{q_{t}^{j}}\right)\right]+\mu_{t}^{i} \gamma_{t}^{j} \kappa_{t}^{j} \\
C_{I, t}^{i(-\sigma)}=E_{t}\left[\beta_{I}\left(C_{I, t}^{i}\right) C_{I, t+1}^{i(-\sigma)} R_{B, t}\right]+\mu_{t}^{i}
\end{gathered}
$$

Equation (4.16) - (4.17) show that investor's marginal utility from investing in the home and foreign fixed assets in period $t$ depends on: 1) the expected return of each asset, 2) the expected asset price in period $t+1$, and 3 ) the marginal value of borrowing against the domestic and foreign asset, respectively. $\mu_{t}^{i}$ is the multiplier on the borrowing constraint. In this model, $\mu_{t}^{i}$ is the shadow value of borrowing and it is greater than zero. This represents the cost of borrowing faced by investors which reduces their return. In addition, equation (4.16) and (4.17) demonstrate the role of time-varying LTV ratios, $\kappa_{t}^{i}$ and $\kappa_{t}^{j}$, and the impact of the financial shock in the economy $\gamma_{t}^{i}$. In fact, time varying LTV ratios are countercyclical which reduces the cost of borrowing when a country $i$ experiences a negative shock to $\gamma_{t}^{i}$, thus increasing the marginal utility of investing in 
country $i .{ }^{17}$ Equation (4.18) is the consumption Euler equations stating that the marginal utility of consumption today is equal to the discounted marginal gain of consumption tomorrow plus the extra unit debt received.

\subsubsection{Savers first order conditions}

The purpose of the following equation is to solve for the savers' optimal variables, using the Lagrange multipliers method. $\lambda_{t}^{s}$ denotes the Lagrangian multiplier for savers.

$$
\begin{aligned}
& L_{S}=E_{0} \sum_{t=0}^{\infty} \beta_{S}\left(C_{S, t}^{i}\right)\left(\frac{C_{S, t}^{i(1-\sigma)}}{1-\sigma}\right) \\
& +\lambda_{t}^{s}\left[W_{t}^{i}+R_{B, t-1} B_{S, t-1}^{i}+q_{t}^{i} K_{S, t-1}^{i}+Z_{t}\left(K_{S, t-1}^{i}\right)^{\omega}-\left(C_{S, t}^{i}+B_{S, t}^{i}+q_{t}^{i} K_{S, t}^{i}\right)\right]
\end{aligned}
$$

The optimal savers' variables are:

$$
\begin{gathered}
C_{S, t}^{i(-\sigma)}=E_{t}\left[\beta_{S}\left(C_{S, t}^{i}\right) C_{S, t+1}^{i-\sigma} R_{B, t}\right] \\
C_{S, t}^{i(-\sigma)}=E_{t}\left[\beta_{S}\left(C_{S, t}^{i}\right) C_{S, t+1}^{i-\sigma}\left(\frac{q_{t+1}^{i}+\omega Z^{i}\left(K_{S, t}^{i}\right)^{(\omega-1)}}{q_{t}^{i}}\right)\right]
\end{gathered}
$$

Equation (4.19) is the standard Euler equation stating that the marginal utility of consuming today is equal to the expected discounted saving's return received from purchasing bonds from domestic and foreign investors. Equation (4.20) tells us that the present value of domestic capital investment is equal to the discounted marginal utility expected from producing the home good.

A firm in country $i$ produces a tradable good and chooses aggregate fixed assets to maximize its profit:

\footnotetext{
${ }^{17}$ With constant LTV ratios, a negative shock decreases the benefit of investing and increase the cost of borrowing.
} 


$$
\underset{\left\{K_{t}^{i i}, K_{t}^{j i}\right\}}{\operatorname{Max}}\left\{Y_{t}^{i}-R_{k, t}^{i i} K_{t}^{i i}-R_{k, t}^{j i} K_{t}^{j i}-W_{t}^{i}\right\}
$$

where $Y_{t}^{i}$ is the production function given by:

$$
Y_{t}^{i}=A_{t}^{i}\left(\left(K_{I, t-1}^{i i}\right)^{\zeta}\left(K_{I, t-1}^{j i}\right)^{1-\zeta}\right)^{\alpha}
$$

From the first order conditions of the firm's problem we have:

$$
\begin{gathered}
R_{k_{I}, t}^{i i}=\zeta \alpha A_{t}^{i}\left(K_{t-1}^{i i}\right)^{\zeta \alpha-1}\left(K_{t-1}^{j i}\right)^{(1-\zeta) \alpha}\left(L_{t}^{i}\right)^{1-\alpha} \\
R_{k_{I}, t}^{j i}=\alpha(1-\zeta) A_{t}^{i}\left(K_{t-1}^{i i}\right)^{\zeta \alpha}\left(K_{t-1}^{j i}\right)^{((1-\zeta) \alpha-1)}\left(L_{t}^{i}\right)^{1-\alpha}
\end{gathered}
$$

Equations (4.23) and (4.24) indicates that in equilibrium, the marginal benefits of domestic and foreign investors received from investing the country $i$ firm's production are equal to the marginal costs. The firm pays a real wage to savers equal to:

$$
W_{t}^{i}=(1-\alpha) A_{t}^{i}\left(\left(K_{I, t-1}^{i i}\right)^{\zeta}\left(K_{I, t-1}^{j i}\right)^{1-\zeta}\right)^{\alpha}
$$

Equation (4.25) says that the firm adjust labor demand such that the marginal benefit is equal to the marginal cost given by the wage.

\subsubsection{Competitive Equilibrium definition}

Taking $\bar{\kappa}^{i}, \bar{\kappa}$, , and the initial assets holdings as given, a competitive equilibrium for this economy is an allocation of

$\left\{C_{I, t}^{i}, K_{t}^{i i}, K_{t}^{i j}, B_{I, t}^{i}, Y_{t}^{i}, C_{I, t}^{j}, K_{t}^{j j}, K_{t}^{j i}, B_{I, t}^{j}, Y_{t}^{j}\right\}_{t=0}^{\infty}$ for investors, an allocation of $\left\{C_{S, t}^{i}, B_{S, t}^{i}, K_{S, t}^{i}, C_{S, t}^{j}, B_{S, t}^{j}, K_{S, t}^{j}\right\}_{t=0}^{\infty}$ for savers of each country and relatives prices $\left\{W_{t}^{i}, R_{K, t}^{i}, R_{K, t}^{j}, q_{t}^{i}, W_{t}^{j}, q_{t}^{j}, R_{B, t}\right\}_{t=0}^{\infty}$ in both countries such that : 
- Given prices, investors and savers maximize their utilities subject to the budget and borrowing constraints.

- Firms maximize profits taking the prices as given.

- The market clearing conditions are satisfied.

\subsection{Parameters values}

In this quantitative exercise we choose parameter values based on standard values used in the literature. These are presented in Table 4.1. We follow Iacoviello and Minetti (2006) and fix the steady state discount factor for savers $\beta_{S}$ is set to 0.99. As in Devereux and Yetman (2010), the investor's discount factor $\beta_{I}$ depends on the loan interest rate and the loan premium equal to 0.02. We follow Trani (2015) and define the discount factor as follows: $\beta(C)=(1+C)^{-\phi}$ with $\phi=\ln \left(R_{B}\right) / \ln (1+C)$. The loan premium value is from Devereux and Yetman (2010). The coefficient of relative risk aversion $\sigma$ is equal to 2 , which is the standard value used in the literature. Following Beau et al. (2011) and Bailliu et al. (2015), the coefficient measuring the responsiveness of macroprudential policies, $\phi_{b}$, to 0.5 in all countries. The steady state of the loan to value ratio is equal to 0.75, standard in the literature. Following Devereux and Yetman (2010), we set the share of capital used by savers to produced domestic good $\omega$ at $0.1 .^{18}$ The coefficients of productivity in home production and in firm's production are equal to 1 in the steady state $\left(Z^{i}=A^{i}=1\right)$. As we consider an inelastic labor supply, the labor supply $L_{t}^{i}$ is normalised to 1 and the two countries have the same size. We set the capital share in the production $\alpha$ to the standard value used in the literature 0.36 as in Devereux and Yetman (2010). We consider investors to have home bias and follow Coeurdacier et al. (2010) to chose a value within the following interval $\frac{1}{2}<\zeta<1$. Hence, we follow Trani (2015) and choose the share of domestic investors holding domestic capital, $\zeta$, is fixed to 65\%. and the share of investors in each economy, $n$, is equal to 0.5. All shocks are

\footnotetext{
${ }^{18}$ This implies that the home production uses $10 \%$ of the total asset in each country. Trani (2015) considers the same value for the saver's domestic fixed asset.
} 
normally distributed and follow an autoregressive process. As in Trani (2015), the coefficient of persistence for the productivity shock $\left(\rho_{A}\right)$ is equal to 0.91 and the coefficient of persistence for the borrowing capacity shocks $\left(\rho_{\gamma}\right)$ is equal to 0.865 . The values of the standard deviation for the productivity and borrowing shocks are equal to $0.6 \%$ and $0.819 \%$, respectively.

Table 4.1: Parameters values

\begin{tabular}{|c|c|c|}
\hline Parameter & & Value \\
\hline Saver discount factor & $\beta_{S}$ & 0.99 \\
\hline Discount factor parameter & $\phi$ & 0.0105 \\
\hline Coefficient of relative risk aversion & $\sigma$ & 2 \\
\hline Credit parameter LTV rule & $\phi_{b}$ & 0.5 \\
\hline LTV ratio & $\kappa^{i}$ & 0.75 \\
\hline Capital share in the home production & $\omega$ & 0.1 \\
\hline Coefficient of Productivity & $A$ & 1 \\
\hline Coefficient of Productivity (backyard production) & $Z$ & 1 \\
\hline Capital share & $\alpha$ & 0.36 \\
\hline Investor's share of capital & $\zeta$ & 0.65 \\
\hline Country size & $n$ & 0.5 \\
\hline Persistence parameter ( productivity shock) & $\rho_{\varphi}$ & 0.91 \\
\hline Persistence parameter ( borrowing capacity shock) & $\rho_{\chi}$ & 0.865 \\
\hline Standard deviation ( productivity shock) & $\sigma_{A}$ & 0.6 \\
\hline Standard deviation ( borrowing capacity shock) & $\sigma_{\gamma}$ & 0.819 \\
\hline Labor supply & $L_{t}^{i}$ & 1 \\
\hline
\end{tabular}




\subsection{Moments and impulse response results}

In this section, we analyze how time-varying LTV ratios can reduce the transmission of macroeconomic instability during periods of crisis. In the following experiments, we consider that investors have the same portfolio diversification with home bias preference (each investor holds $65 \%$ of domestic asset). ${ }^{19}$ We also assume that the LTV ratios are homogeneous in the two countries. To understand the impact of time-varying LTV ratios on the transmission of shocks, we compare the variables' responses under active (or time-varying) LTV ratios and under passive (or constant) LTV ratios in both countries.

\subsubsection{International business cycle moments}

Table 4.2: International business cycle moments

\begin{tabular}{|c|c|c|c|c|c|c|}
\hline & Data & Constant LTV & Time-Varying LTV & Trani (2015) & Coeurdacier et al. (2010) & Backus et al. (1992) \\
\hline \multicolumn{6}{|c|}{ Standard deviation } & \\
\hline Output & 1.29 & 1.17 & .89 & 1.52 & 1.87 & 1.55 \\
\hline Consumption & 0.98 & 1.08 & .76 & 0.88 & 0.76 & 0.62 \\
\hline Net Foreign Equity & 2.97 & 2.34 & 1.26 & na. & 3.31 & - \\
\hline Net Export/GDP & 0.4 & 0.35 & 0.35 & 0.06 & 1.07 & 2.9 \\
\hline \multicolumn{6}{|c|}{ Correlation with domestic output } & \\
\hline Consumption & 0.8 & 0.95 & 0.92 & 0.84 & 0.38 & 0.79 \\
\hline Net Export/GDP & -0.35 & 0.38 & 0.52 & 0.58 & -0.07 & -0.02 \\
\hline Foreign equity & -0.22 & 0.3 & 0.08 & na. & 0.23 & - \\
\hline \multicolumn{6}{|c|}{ Cross-country correlations } & \\
\hline Output & 0.56 & 0.31 & 0.05 & 0.31 & 0.17 & -0.18 \\
\hline Consumption & 0.36 & 0.52 & 0.42 & 0.88 & 0.58 & 0.88 \\
\hline
\end{tabular}

We use quarterly US Data retrieved from FRED database for the period 1960q1-2017q3. All variables are logged and detrended using a HP filter (smoothing parameter is equal to 1600). The international correlations are from Trani (2015) in Table 2 using cross country correlation of G7 countries. The Net Foreign Asset value is reported by Coeurdacier et al.(2010) in Table 3.

Table 4.2 reports the business cycle moments for US quarterly data from 1960q1-2017q3 which we compare to our simulated moments from the model. We report the simulation from our model with constant LTV ratios in column 3 and simulation from our model with time-varying LTV

\footnotetext{
${ }^{19}$ We also considered the degree of home biasedness to be equal to $75 \%$ and found similar results.
} 
ratios in column 4 . We report the standard deviations for output, consumption, net foreign equity and net export to GDP ratio, as well as their correlation with domestic output. We also report cross-country correlations of output and consumption. We compare our results to findings in Trani (2015), Coeurdacier et al. (2010) and Backus et al. (1992) as all of these papers used variants of the international real business cycle model.

Overall, we find that simulated results predicted by our model are close to the data for some variables. For the model with constant LTV ratios, we find the standard deviations of the output, net foreign equity and net exports to GDP ratio to be closer to the data compared to the other papers. The correlation between consumption and output is also close to the data compared to the values reported in Coeurdacier et al. (2010) and Backus et al. (1992). We also find the simulated moments for net export to GDP to be closer to the data than results reported by Trani (2015) and Coeurdacier et al. (2010). Our model produces cross-country correlations in consumption and output that are close to the data. For the model with time-varying LTV ratios, we find that the standard deviations of the output, net foreign equity and net exports to GDP ratio are lower than the model with constant LTV ratios.. The other moments from the model with time-varying LTV ratios are similar in magnitude to those generated in the model with constant LTV ratios.

As expected, we find that the volatility of the macroeconomic variables considered is higher in the model with constant LTV ratios compared to the model with time-varying LTV ratios. The countercyclicality of the LTV reduces volatility of variables. We observe also a higher volatility of consumption than in all other models. The net export volatility is higher in the model with constant LTV ratios than in Trani (2015). In Trani (2015), investors can smooth consumption bettern than in our model by adjusting the share of capital then hold. However, in our model the share of capital held by investors in exogeneous.

The standard deviation of consumption is expected to be lower in Coeurdacier et al. (2010) and in Backus et al.(1992) than in our model because their households do not face borrowing constraints. Therefore, they can smooth consumption better than in our model.

We conduct a sensitivity analysis where we allow the steady state level of the LTV ratio to 
change. A comparison of the simulated results when $\bar{\kappa}^{i}$ and $\bar{\kappa}^{i}$ are equal to $0.75,0.85$ and 0.95 shows that a lower steady state LTV ratios reduces the volatility of variables in both of the model with LTV ratios. However, the introduction of time varying LTV ratio reduces the volatility of the variables even if the steady state LTV ratios is high because the policy reduces the deviation of the financial variables from their steady state values.

\subsubsection{Cross-country transmission of a productivity shock}

Figure 4.1 presents the dynamic responses of key variables to a negative one standard deviation productivity shock in the home country. The solid (dashed) line depicts responses under constant (time-varying) LTV ratios. The home (foreign) country macroeconomic variables' responses are presented in the first (second) row. A negative productivity shock in the home country reduces output, borrowing, asset prices and total equity investment defined as domestic and foreign equity in equation 4.2 in both countries. In fact a negative productivity shock increases the marginal cost of investing as the capital stock value and the net wealth of investors decline with the decline of the equity price. Therefore, investment, output and consumption decrease in the country experiencing the shock. The results show that the transmission of shocks is stronger when countries have constant LTV ratios. Under constant LTV ratios - where the value of the collateral does not adjust to the change of equity price - a negative shock directly affects the asset's value and causes the co-movements of variables across countries because production and investment decrease as the value of the asset declines. ${ }^{20}$ Therefore, the amount of funds an investor can borrow drops as the investor's net worth declines. Thus, investment, production and consumption also decrease. The implementation of time-varying LTV ratio in each country reduces quantitatively the effect of the shock mostly on borrowing and equity holdings. Hence, investors who have access to credit can keep investing and producing goods which explains the weak reaction to the shock in the home country.

\footnotetext{
${ }^{20}$ This co-movement is standard in a RBC model, where a negative technology shock induces output, consumption, investment and capital to decrease at the same rate.
} 
The transmission of the shock in the foreign country is strong under constant LTV ratios in the two countries. It is influenced by the fall of the domestic's country asset price leading to a low net worth of domestic and foreign borrowers, which reduces the amount of funds that can be borrowed for investment in the two countries. Quantitatively, the performance of economic variables is different in the home country and the foreign country when the two countries have time varying LTV ratios. In the home country, output drops by $0.7 \%$ when LTV ratios are constant and by $0.6 \%$ when LTV ratios are time-varying. In the foreign country, the shock reduces output by $0.2 \%$ under constant LTV ratios and by $0.05 \%$ under time-varying LTV ratios. These differences show that time varying LTV ratios can reduce transmission of productivity shocks across countries. A time-varying LTV ratio mitigates the reaction to the shock because it compensates the decline of asset values pledged as collateral by relaxing the borrowing constraint under a negative productivity shock. Hence, accessibility to credit reduces the fluctuations of macroeconomic variables, especially in the foreign country.

Figure 4.2: Impulse responses following a negative productivity shock in the home country
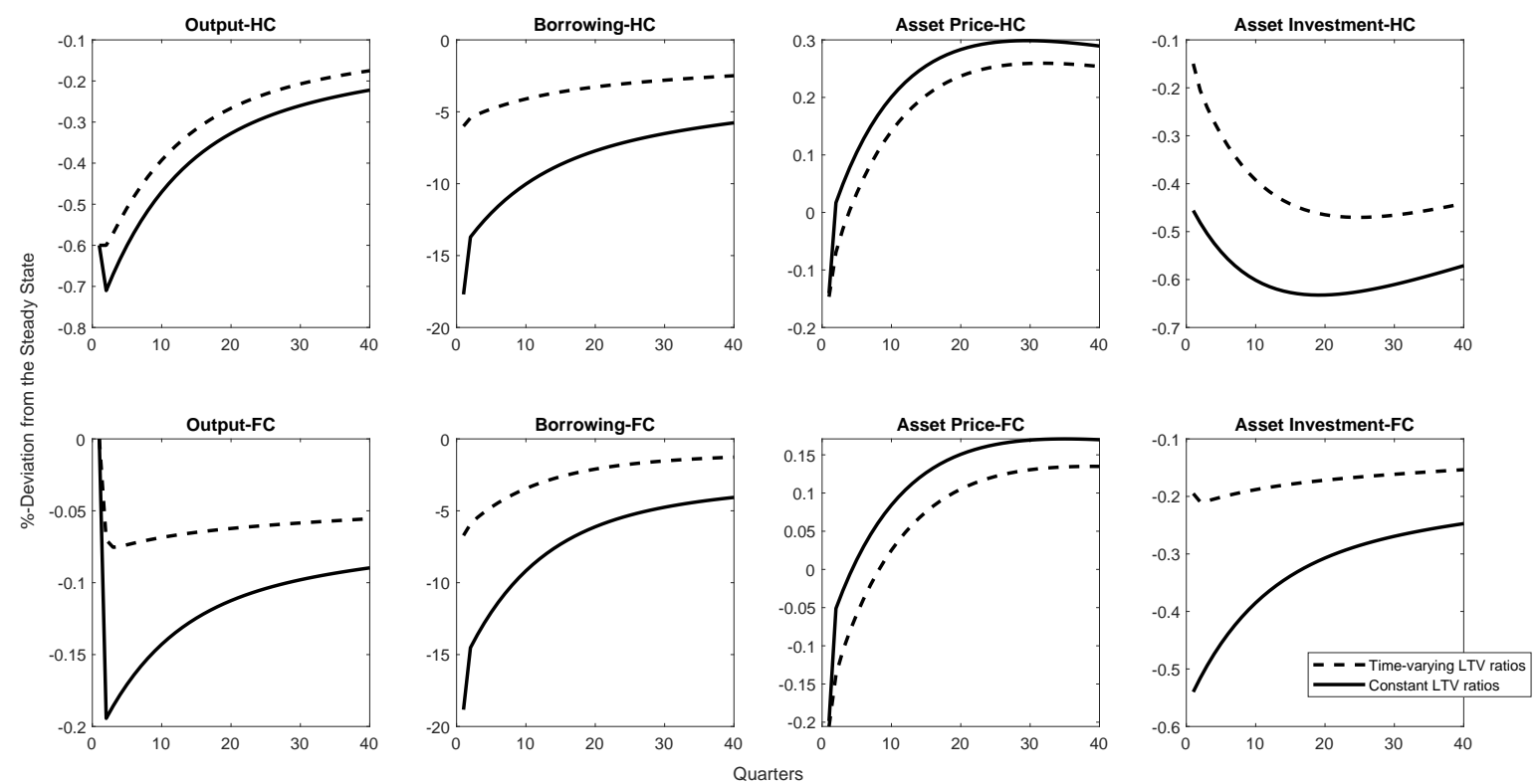

Note: The solid line depicts responses to a one standard deviation negative productivity shock under constant LTV ratios and the dashed line represents the responses under time-varying LTV ratios. HC: Home Country, FC: Foreign Country. 
These results are in line with the other studies. For example, Boar et al. (2017) study the impact of macroprudential policies on macroeconomic performance and find that the usage of macroprudential policies reduces volatility of GDP growth by about $0.3 \%$ in countries with a developed financial sector or in countries open to financial activities. In the same vain, Gambacorta and Murcia (2017) find that macroprudential policies are able to stabilize credit cycles in emerging and advanced economies. In an empirical analysis, Neanidis (2017) shows that the implementation of macroprudential policies support economic growth because they are able to reduce the negative impact of capital flows' volatility across countries by over $40 \%$. We are able to find similar results in a theoretical model.

\subsubsection{Cross-country transmission of a borrowing capacity shock}

Figure 4.3 shows the responses of key variables to a negative one standard deviation borrowing capacity (financial) shock to the home country capturing the change of collateral asset value. The solid (dashed) line depicts responses under constant (time-varying) LTV ratios. The home (foreign) country macroeconomic variables' responses are presented in the first (second) row. We observe that under constant LTV ratios, the decline in the borrowing capacity has a direct impact in both countries. There is a reduction of output, borrowing, asset prices and equity market investment (see remaining IRFs in Appendix D). The responses of the lending rate and asset prices in both countries explain the transmission of the shock. A decline in the borrowing capacity in the domestic country has a direct impact on the domestic asset prices as it reduces the value of the collateral. In addition, the shock reduces the world interest rate, which discourages savers from purchasing bonds. Hence, due to the global diversification of investment these factors reduce the value of the global equity market.

Time-varying LTV ratios mitigate the effect of the shock because they are countercyclical. The negative shock relaxes the policies and gives investors the ability to borrow by pledging lower value assets. This policy reduces the fluctuation of the world interest rate and asset prices response, which allows investors to borrow at a lower rate and pledge high value asset. Endogenous LTV 
ratios encourage borrowers to invest in the country not experiencing the shock. Consequently the output response to the shock in the foreign country under time-varying LTV ratios increases, whereas it decreases under constant LTV ratios. The value of the foreign country asset is not affected by the negative shock from the home country.

Figure 4.3: Impulse responses following a negative borrowing capacity shock in the home country
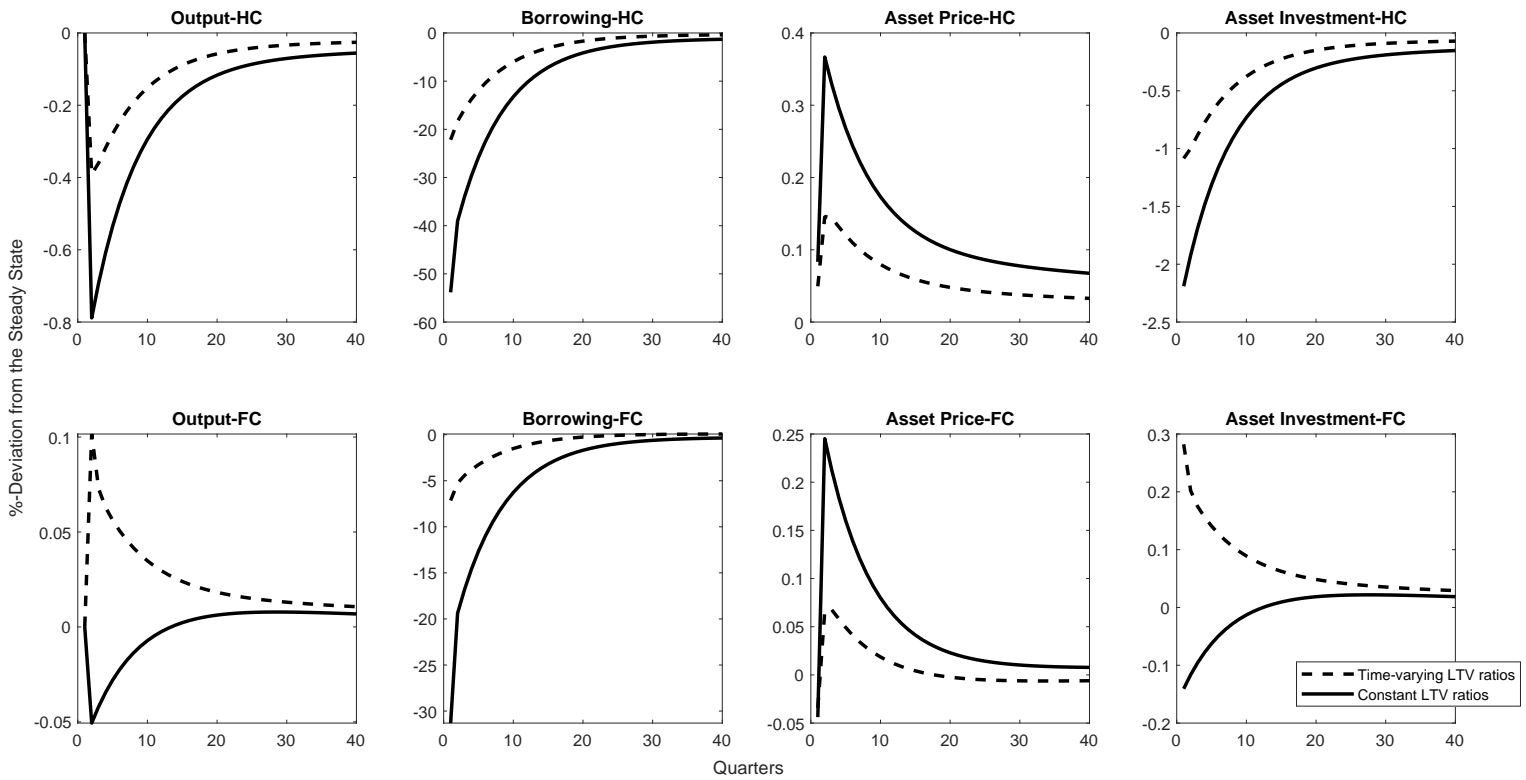

Note: The solid line depicts responses to a negative one standard deviation borrowing capacity shock under constant LTV ratios and the dashed line represents the responses under time-varying LTV ratios. HC: Home Country, FC: Foreign Country.

Figure 4.2 and 4.3 show that the impact of time-varying LTV ratios on transmission of shocks is stronger on output under a financial shock than under a productivity shock because the policies react directly to the deviation of credit from the steady state, which affects directly the asset value and the loan an investor can receive. 


\section{Comparison of time varying LTV ratios and constant LTV ratios}

Figure 4.4 demonstrates how constant and time-varying LTV ratios respond differently to the shocks. Constant LTV ratios (solid line) do not respond to the shocks because the value of the collateral is fixed and does not depend on the state of the economy. However, time-varying LTV ratios increase when the domestic country experiences a negative shock to either productivity orborrowing capacity. The time-varying LTV ratios are countercyclical which means that in case of a negative shock, the ratio increases the value of the collateral. Thus, the net worth of investors both domestic and foreign investors does not decline when the economy slows down. The impact is stronger under a financial shock than a productivity shock. This is due to the fact that the variation of credit growth, directly affected by the shock, is used as a financial indicator.

\section{Figure 4.4: LTV responses to productivity and borrowing capacity shocks}
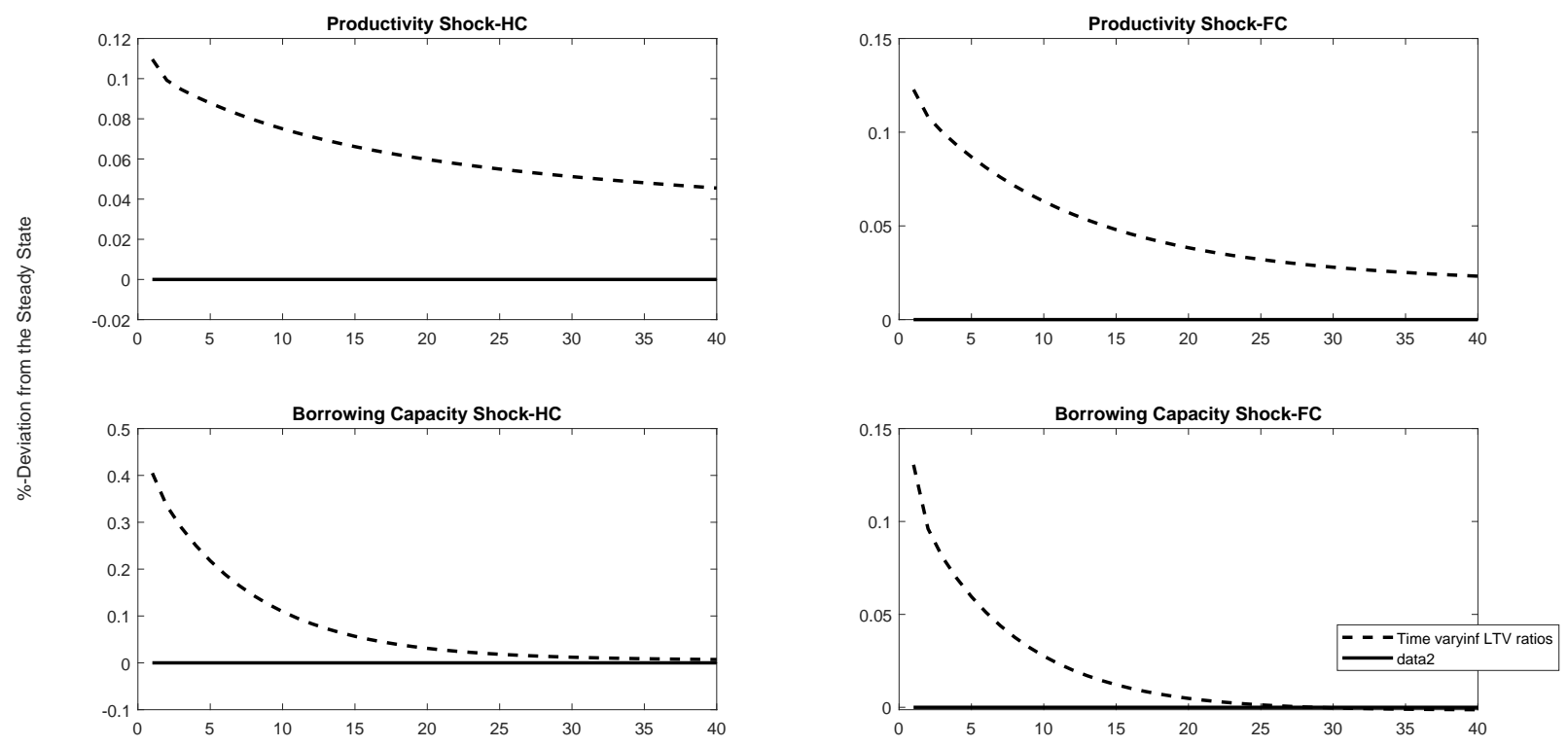

Note: The solid line represents the response of constant LTV ratios to the shocks and the dashed line represents the response of time-varying LTV ratios to the shocks. 


\subsection{Conclusion}

In this chapter, we investigate the effect of LTV ratio macroprudential policies on the transmission of negative shocks in countries open to cross-border financial activities. Previous research has shown that the recent financial crisis was transmitted across countries through financial integration. We show how macroprudential policies can increase financial stability of the global economy. We use a two-country DSGE model with macroprudential policies in the form of LTV ratios that are implemented to regulate the fluctuation of credit. Our analysis on the transmission of negative shocks across countries shows that when a country experiences a negative shock ${ }^{21}$ while timevarying LTV ratios are implemented, the transmission effect is weaker than when LTV ratios are constant. This is because the time-varying LTV ratios reduce the fluctuation of financial vulnerability indicators, such as asset prices or credit growth. When a country experiences a negative shock, the time-varying LTV ratios allow the investors to borrow more despite the low value of the collateral. ,Using this model, we are able to demonstrate that the transmission of shocks and co-movement of macroeconomic variables across countries can be reduced if policymakers adopt time-varying LTV ratios.

\footnotetext{
${ }^{21}$ A financial or productivity shock.
} 


\section{Chapter 5}

\section{Summary and Conclusion}

Due to the rapid rise of international financial activities since the mid-1990's (BIS (2017)) and the reforms in many countries' financial sectors after the 2007 financial crisis, we find it important to study the issue related to the impact of macroprudential policies on management of credit growth at the international level and on the transmission of shocks across countries. ${ }^{1}$ Since the policymakers implement policies to reduce systemic risk at the country level, it is evident that the policies can be heterogeneous and may have different effects at the international level (see Table 3.1 and Table 3.2). ${ }^{2}$ We argue that financial institutions such as banks and international investors could avoid strict policies by increasing international financial activities toward countries with less strict policies, which can increase ineffectiveness of macroprudential policies and amplify the propagation of financial crises in the future.

This dissertation evaluates the issues related to the avoidance and the ineffectiveness of the policies because of the openness to cross-border financial and economic activities. We focus on capital requirements and loan-to-value ratio prudential policies. Table A.1 and Table A.2 show that these policies have been used frequently in advanced and emerging countries. In Chapter 2, we empirically analyze how international cross-border lending originating from advanced countries

\footnotetext{
${ }^{1}$ International financial activities are important and help to increase economic growth.

${ }^{2}$ Schwarcz (2008) defines systemic risk as an economic shock or an institutional failure, which causes a chain of negative economic consequences such as a dramatic increase of financial market price volatility and the inability of financial markets and institutions to provide regular financial services.
} 
respond to the usage of capital requirements and loan-to-value ratios in the eurozone, advanced non-eurozone and emerging countries over the period of 2000-2014. The goal is to understand if macroprudential policies of countries involved in cross-border credit are useful in reducing credit growth in times of high financial vulnerability such as times of a high credit boom across countries. Figure 2.2 shows that in period preceding the 2007 financial crisis, countries in our sample (particularly advanced economies) experienced a rapid increase of debt to service ratio (our measure of financial vulnerability) making households and firms very vulnerable to a crisis. Macroprudential policies are implemented to reduce the risk of crisis based on warning indicators such as debt to service ratio. Therefore, we evaluate how international banking lending responds to the interaction of macroprudential policies with the warning indicator of financial vulnerability (both domestic and foreign interactions). We find that in some countries, tight macroprudential policies (from borrowing and lending countries) increase international bank lending which undermined their effectiveness in reducing credit growth. In fact, a rapid rise of credit increases the financial fragility of any country as it comes with excessive risk taking and a rise in the probability of borrowers defaulting on their credit. Hence, policymakers in countries open to cross-border banking activities should consider international credit supply when implementing the policies but also they should implement policies which complement each other so that they can achieve their goal of reducing excessive credit growth in times of economic growth.

In Chapter 3, we study how to improve the effectiveness of macroprudential policies at the international level by reducing credit build up and propagation of shocks across financially countries integrated using a two-country DSGE model. We develop different ways of reducing international credit build up. First, we suggest that countries should implement complementary macroprudential policies which means that capital requirements and LTV ratios are time varying in the two countries. This strategy minimizes credit build up under productivity and borrowing capacity shocks. In fact, a tight LTV ratio reduces credit growth by limiting the amount of credit a borrower can receive from domestic and foreign lenders and high capital requirements to banks limit credit supply by reducing the fund available for credit. Second, we consider coordination of capital requirements 
where capital requirements are active in both countries and adjust with the change of credit supply by all banks. We demonstrate that coordination of macroprudential policies across countries does not reduce credit build as fast as complementary policies. Although banks are able to reduce credit supply, this strategy does not consider the variation of LTV ratio. Therefore, investors can still increase borrowing from different lenders when a shock hits their country.

In Chapter 4, we study the implications of macroprudential policies across countries on the transmission of shocks when international investment activities are allowed. In a two-country DSGE model where international investors are borrowing constraint and pledge international asset, we introduce time-varying LTV ratios. Each asset pledged is subject to a LTV ratio varying with credit growth of the country of origin. We examine the effect of these policies under a productivity and a borrowing capacity shock. The results show that implementing time-varying LTV ratio in financially linked countries reduces the transmission of shocks and the fluctuation of macroeconomic variables when one of the financially linked countries experiences a negative productivity or borrowing capacity shock. In fact, time varying LTV ratios adjust with the decline of financial asset values by increasing the limit of credit the borrower can receive despite the low value of the collateral due to the negative shock. This helps investors to continue borrowing and producing when a country experiences a negative productivity or financial shock. We find similar results for either shock. In addition, time-varying LTV ratios minimize the transmission of shocks to other countries linked through international financial investment. As credit does not fluctuate due to the LTV adjustment, there is no reduction of international investors balance sheets which allow investment and productivity to continue.

Although we suggest that countries involved in cross-border financial and economic activities should consider international coordination of macroprudential policies, we also believe that further analysis is still necessary. In future work, we plan to analyze closely why different groups of countries have reacted differently to the implementation of macroprudential policies. This is important because coordination of macroprudential policies can still be ineffective if heterogeneity of the policies is not the main reason why cross-border lending has changed since the implementation of 
macroprudential policies. Different extensions should be considered. One should examine if the magnitude of the 2007 financial crisis effects on a specific country have an effect which coincide witht the international impact of macroprudential policies. For example, when the economic activities slowdown in a specific countries, banks would have a tendency to increase international lending. Second, we should compare the international effect of macroprudential policies to the national effect of macroprudential policies. For example, by comparing the effect of macroprudential policies on international lending to the national effect such as the change of credit supply by non regulated financial institutions such as shadow banks. It is important to mention that in our empirical study we were limited by the short period of study. Future studies should consider a longer period of study. Particularly, the analysis should focus on the effect of macroprudential policies after the recovery from the 2007 financial crisis to include periods where monetary policies were not low in many countries to affect credit demand. In addition, the model developed in the third chapter should be extended to consider that, not only there exists heterogeneous macroprudential policies at the international level, but also within each country, financial institutions involved in lending do not face the same regulations. 


\section{Appendix A: Additional Tables -Chapter 2}

Table A.1. Usage of Macroprudential Policies in Emerging Countries and Advanced Economies

\begin{tabular}{|c|c|c|c|c|}
\hline \multicolumn{2}{|c|}{ Number of changes observed for each prudential policy : 2000-2014 } \\
\hline \hline & Emerging Economies & \multicolumn{2}{|c|}{ Advanced Economies } \\
\hline Tightening & Loosening & Tighenning & Loosening \\
\hline Capital Buffers- Housing sector & 25 & 8 & 10 & 3 \\
\hline General Capital Buffers & 16 & 4 & 10 & 3 \\
\hline Capital Requirement & 22 & 0 & 41 & 0 \\
\hline Interbank Exposure & 4 & 0 & 13 & 0 \\
\hline LTV ratio & 27 & 7 & 15 & 6 \\
\hline Reserve requirements (Foreign currency accounts.) & 35 & 24 & 0 & 0 \\
\hline Reserve requirements ( Local currency accounts.) & 64 & 57 & 0 & 22 \\
\hline Concentration Limits & 11 & 1 & 9 & 0 \\
\hline
\end{tabular}

The numbers represent the number of time each policy has been tightened or relaxed. 
Table A.2. Usage of Macroprudential policies in Eurozone and Advanced non Eurozone countries

\begin{tabular}{|c|c|c|c|c|}
\hline \multicolumn{5}{|c|}{ Number of changes observed for each prudential policy : 2000-2014 } \\
\hline & \multicolumn{2}{|c|}{ Advanced Countries-non-Eurozone } & \multicolumn{2}{|c|}{ Eurozone Countries } \\
\hline & Tightening & Loosening & Tighenning & Loosening \\
\hline Capital Buffers- Housing sector & 7 & 3 & 3 & 0 \\
\hline General Capital Buffers & 7 & 3 & 3 & 0 \\
\hline Capital Requirements & 21 & 0 & 20 & 0 \\
\hline Interbank Exposure & 8 & 0 & 5 & 0 \\
\hline LTV ratio & 10 & 4 & 5 & 2 \\
\hline Reserve requirements (Foreign curr. acts.) & 0 & 0 & 0 & 0 \\
\hline Reserve requirements ( Local curr. acts.) & 0 & 2 & 0 & 20 \\
\hline Concentration Limits & 1 & 0 & 8 & 0 \\
\hline
\end{tabular}

The numbers represent the number of time each policy has been tightened or relaxed.

Table A.3. List of lending countries ( Source countries)

\begin{tabular}{|c|c|c|c|c|}
\hline \multicolumn{5}{|c|}{ Lending Countries } \\
\hline \hline Austria & Australia & Belgium & Switzerland & Germany \\
\hline Denmark & Spain & France & United Kingdom & Greece \\
\hline Japan & Netherlands & Portugal & Sweden & USA \\
\hline
\end{tabular}


Table A.4. List of borrowing countries ( Destination countries)

\begin{tabular}{|c|c|c|c|c|}
\hline \multicolumn{5}{|c|}{ Borrowing Countries } \\
\hline \hline Austria & Australia & Belgium & Brazil & Canada \\
\hline Switzerland & Chile & China & Germany & Denmark \\
\hline Spain & Finland & France & United Kingdom & Greece \\
\hline Hong Kong & Hungary & Ireland & India & Indonesia \\
\hline Italy & Japan & Malaysia & New Zealand & Mexico \\
\hline Netherlands & Norway & Portugal & Russia & Sweden \\
\hline Thailand & Turkey & United States & South Africa & \\
\hline
\end{tabular}

Table A.5. Data Description

\begin{tabular}{|c|c|c|c|}
\hline Variables & Unit & Source & Description \\
\hline Capital Requirements & Dummy & Cerutti et al. (2016) & 1 if the policy change, 0 if there is no change \\
\hline Loan-To-Value Ratio & Dummy & Cerutti et al. (2016) & 1 if the policy change, 0 if there is no change \\
\hline Debt-to-Service Ratio & Ratio & BIS database & Private non-financial sector \\
\hline Bilateral Banking Claims & in USD & BIS, consolidated Banking Statistics & Consolidated foreign claims of reporting banks ( 15 countries) \\
\hline GDP growth & in USD & World Bank - WDI database & Gross Domestic Product in Millions USD \\
\hline Trade Openness & Ratio & World Bank - WDI database & Ratio of total Import and Export to GDP \\
\hline Long Term Loan Interest Rate & $\%$ & IMF- IFS database & Interest Rates, Monetary Policy - Related Interest Rate \\
\hline Capital to Asset Ratio & $\%$ & World Bank - WDI database & Ratio of Bank Capital and Reserves to Total Assets \\
\hline Alternative LTV Ratio & Ratio & BIS database & Ratio of total household credit to real housing price \\
\hline
\end{tabular}


Table A.6. Summary Statistics

\begin{tabular}{|cccccc|}
\hline Variable & Obs & Mean & Std.Dev. & Min & Max \\
\hline Capital Requirements dummy (Destination) & 6645 & .11 & .34 & 0 & $2^{3}$ \\
Capital Requirements dummy (Source) & 6645 & .13 & .35 & 0 & 2 \\
LTV ratio dummy (Destination) & 6450 & .06 & .35 & -1 & 3 \\
LTV ratio dummy (Source) & 6450 & .01 & .22 & -1 & 1 \\
Capital to Asset Ratio (Destination) & 5780 & 1.9 & .34 & .99 & 2.7 \\
Capital to Asset Ratio (Source) & 5814 & 1.7 & .3 & .99 & 2.5 \\
LTV ratio ( Destination) & 5151 & 10.1 & 21.5 & -.007 & 142.4 \\
LTV ratio ( Source) & 5333 & 17.9 & 29.6 & .903 & 142.4 \\
Debt Service ratio (Destination) & 6645 & 4.78 & .59 & 2.9 & 5.8 \\
Debt Service ratio (Source) & 6645 & 4.92 & .48 & 3.1 & 5.6 \\
GDP (Destination) & 6645 & 22.6 & .28 & 19.99 & 25.8 \\
Trade openness ( Destination) & 6645 & -.34 & .58 & -1.62 & 1.51 \\
Long Term Interest Rate (Destination) & 5100 & 1.43 & .55 & -.66 & 3.56 \\
GDP (Source) & 6645 & 23.1 & 1.24 & 21.1 & 25.8 \\
Trade openness ( Source) & 6645 & -.44 & .50 & -1.62 & .503 \\
Long Term Interest Rate ( Source) & 5100 & 1.26 & .51 & -.66 & 3.11 \\
\hline
\end{tabular}

\footnotetext{
${ }^{3}$ The maximum value is greater than 1 because the macroprudential policy has changed twice within a year in some countries.
} 
Appendix B: Other Results-Chapter 2 
Table B.1. Effects of capital requirements on bilateral cross-border credit from Advanced non eurozone countries

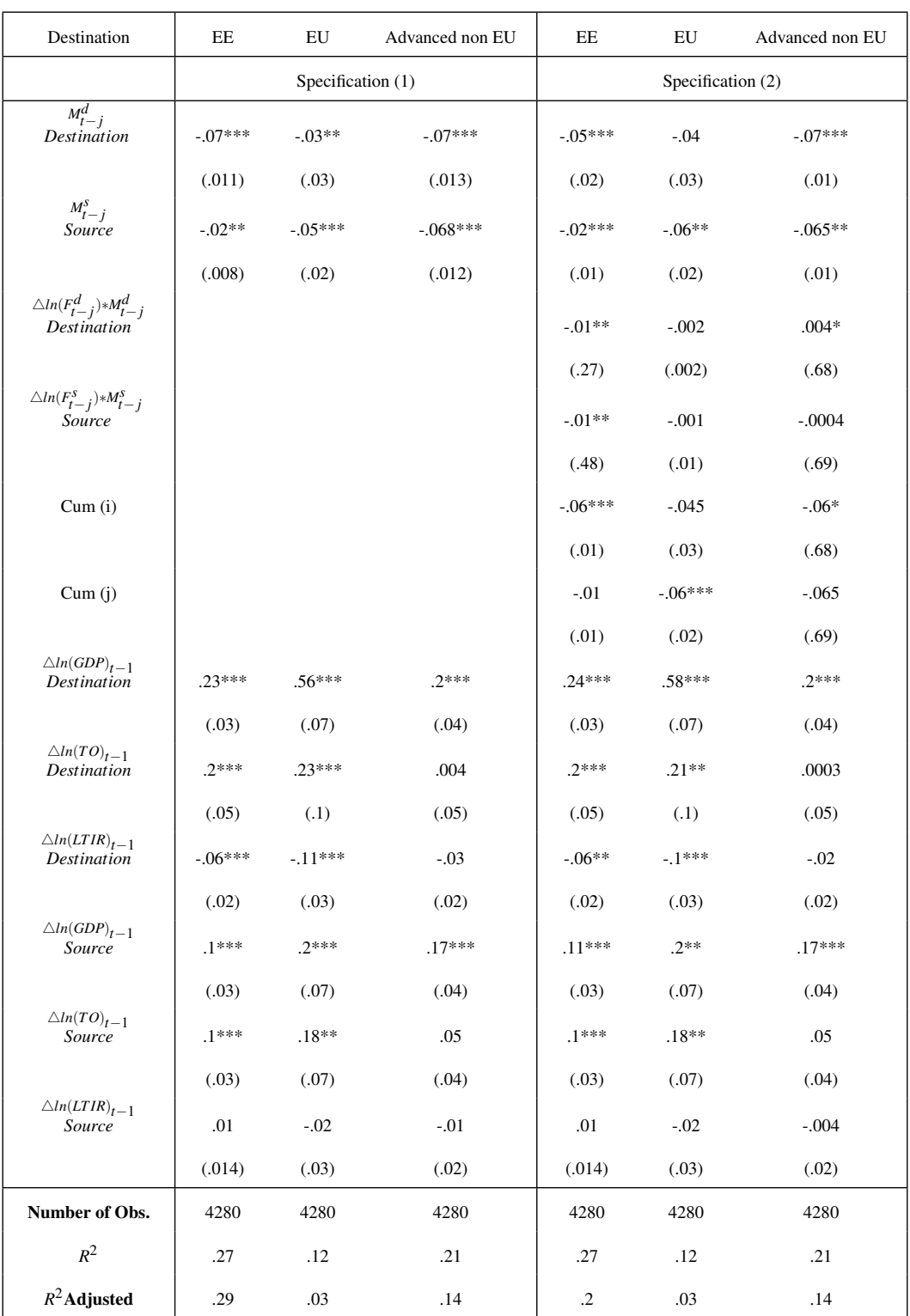

NoNote: The dependent variable is the growth of bilateral cross-border credit from Advanced non eurozone Countries (Source Countries) to the Emerging, Eurozone and Advanced non-Eurozone countries. (1) reports the cumulative effect of stand alone macroprudential policies and control variables on bilateral cross-border credit. (2) extends (1) by including the cumulative effect of the interaction between macroprudential instrument and financial vulnerability variable for destination and source countries. In each specification we consider a country and a time fixed effects. M is a dummy capital requirement macroprudential tool. $\mathrm{d}$ is the destination countries and $\mathrm{s}$ is the source countries. There 34 destination countries and 15 source countries. TO is trade openness. LTIR is the long term interest rate. $* * * * *, *$ indicate results significant at the $1 \%, 5 \%$ and $10 \%$ level respectively. Standard errors are in (). 
Table B.2. Effects of LTV ratio on bilateral cross-border credit from Advanced non eurozone coun-

\section{tries}

\begin{tabular}{|c|c|c|c|c|c|c|}
\hline Destination & $\mathrm{EE}$ & EU & Advanced non EU & $\mathrm{EE}$ & $\mathrm{EU}$ & Advanced non EU \\
\hline & \multicolumn{3}{|c|}{ Specification (1) } & \multicolumn{3}{|c|}{ Specification (2) } \\
\hline $\begin{array}{c}M_{t-j}^{d} \\
\text { Destination }\end{array}$ & $.035^{*}$ & .03 & -.017 & .036 & .025 & $-.024 *$ \\
\hline & $(.021)$ & $(.032)$ & (.011) & $(.03)$ & $(.03)$ & $(.01)$ \\
\hline $\begin{array}{c}M_{t-j}^{s} \\
\text { Source }\end{array}$ & $\begin{array}{l}.05 * * * \\
(.011)\end{array}$ & $\begin{array}{l}.07 * * * * \\
(.02)\end{array}$ & $\begin{array}{c}.02 \\
(.014)\end{array}$ & $\begin{array}{l}-.021 \\
(.02)\end{array}$ & $\begin{array}{l}-.1 * * \\
(.05)\end{array}$ & $\begin{array}{l}-.02 \\
(.03)\end{array}$ \\
\hline $\begin{array}{c}\Delta \ln \left(F_{t-j}^{d}\right) * M_{t-j}^{d} \\
\text { Destination }\end{array}$ & & & & $\begin{array}{l}.001 \\
(.02)\end{array}$ & $\begin{array}{l}.01^{*} \\
(.003)\end{array}$ & $\begin{array}{l}.001 \\
(.001)\end{array}$ \\
\hline $\begin{array}{l}\Delta \ln \left(F_{t-j}^{s}\right) * M_{t-j}^{s} \\
\quad \text { Source }\end{array}$ & & & & $\begin{array}{l}.02^{* * *} \\
(.01)\end{array}$ & $\begin{array}{l}.05 * * * \\
(.01)\end{array}$ & $\begin{array}{l}.001 \\
(.007)\end{array}$ \\
\hline Cum. effect. (i) & & & & $\begin{array}{l}.037^{*} \\
(.02)\end{array}$ & $\begin{array}{l}.035 \\
(.033)\end{array}$ & $\begin{array}{l}-.02 * \\
(.012)\end{array}$ \\
\hline Cum . effect (j) & & & & $\begin{array}{l}-.002 \\
(.02)\end{array}$ & $\begin{array}{l}-.06 \\
(.04)\end{array}$ & $\begin{array}{l}.01 \\
(.02)\end{array}$ \\
\hline $\begin{array}{l}\triangle l n(G D P)_{t-1} \\
\text { Destination }\end{array}$ & $.3 * * *$ & $.6^{* * *}$ & $.18 * * *$ & $.3 * * *$ & $.6^{* * * *}$ & $.18 * * *$ \\
\hline & $(.03)$ & $(.07)$ & $(.04)$ & $(.03)$ & $(.07)$ & $(.04)$ \\
\hline $\begin{array}{l}\triangle \ln (T O)_{t-1} \\
\text { Destination }\end{array}$ & $.19 * * *$ & $.2 * *$ & -.002 & $.18^{* * * *}$ & $.2 * *$ & -.01 \\
\hline & $(.05)$ & (.09) & $(.05)$ & (.05) & $(.09)$ & $(.05)$ \\
\hline $\begin{array}{l}\triangle \ln (\text { LTIR })_{t-1} \\
\text { Destination }\end{array}$ & $-.04 *$ & $-.1 * * *$ & .001 & $-.06 * *$ & $-.1 * * *$ & .0003 \\
\hline & $(.02)$ & $(.02)$ & $(.02)$ & (.03) & $(.02)$ & $(.02)$ \\
\hline $\begin{array}{l}\triangle \ln (G D P)_{t-1} \\
\quad \text { Source }\end{array}$ & $\begin{array}{l}.09^{* * * *} \\
(.03)\end{array}$ & $\begin{array}{l}.2^{* * * *} \\
(.07)\end{array}$ & $\begin{array}{l}.14 * * * * \\
(.04)\end{array}$ & $\begin{array}{l}.08^{* *} \\
(.03)\end{array}$ & $\begin{array}{l}.16^{* * *} \\
(.07)\end{array}$ & $\begin{array}{l}.14 * * * \\
(.04)\end{array}$ \\
\hline $\begin{array}{l}\Delta \ln (\mathrm{TO})_{t-1} \\
\quad \text { Source }\end{array}$ & $\begin{array}{l}.08 * * \\
(.03)\end{array}$ & $\begin{array}{l}.16^{* *} \\
(.07)\end{array}$ & $\begin{array}{l}.02 \\
(.04)\end{array}$ & $\begin{array}{l}.07^{* *} \\
(.03)\end{array}$ & $\begin{array}{l}.13^{*} \\
(.07)\end{array}$ & $\begin{array}{l}.01 \\
(.04)\end{array}$ \\
\hline $\begin{array}{l}\triangle l n(\text { lTIR })_{t-1} \\
\quad \text { Source }\end{array}$ & $\begin{array}{l}.006 \\
(.014)\end{array}$ & $\begin{array}{l}-.02 \\
(.03)\end{array}$ & $\begin{array}{l}.01 \\
(.02)\end{array}$ & $\begin{array}{l}.005 \\
(.014)\end{array}$ & $\begin{array}{l}-.02 \\
(.03)\end{array}$ & $\begin{array}{l}.01 \\
(.02)\end{array}$ \\
\hline Number of Obs. & 4115 & 4115 & 4115 & 4115 & 4115 & 4115 \\
\hline$R^{2}$ & .26 & .12 & .2 & .26 & .12 & .2 \\
\hline$R^{2}$ Adjusted & .2 & .03 & .13 & .2 & .03 & .13 \\
\hline
\end{tabular}

Note: The dependent variable is the growth of bilateral cross-border credit from Advanced non eurozone Countries (Source Countries) to the Emerging, Eurozone and Advanced non-Eurozone countries. (1) reports the cumulative effect of stand alone macroprudential policies and control variables on bilateral cross-border credit. (2) extends (1) by including the cumulative effect of the interaction between macroprudential instrument and financial vulnerability variable for destination and source countries. In each specification we consider a country and a time fixed effects. $M$ is a dummy LTV ratio macroprudential tool. $d$ is the destination countries and $s$ is the source countries. There 34 destination countries and 15 source countries. TO is trade openness. LTIR is the long term interest rate. $* * * * * * *$ indicate results significant at the $1 \%, 5 \%$ and $10 \%$ level respectively. Standard errors are in (). 
Table B.3.Effects of capital to asset ratio on bilateral cross-border credit from Advanced non eurozone countries

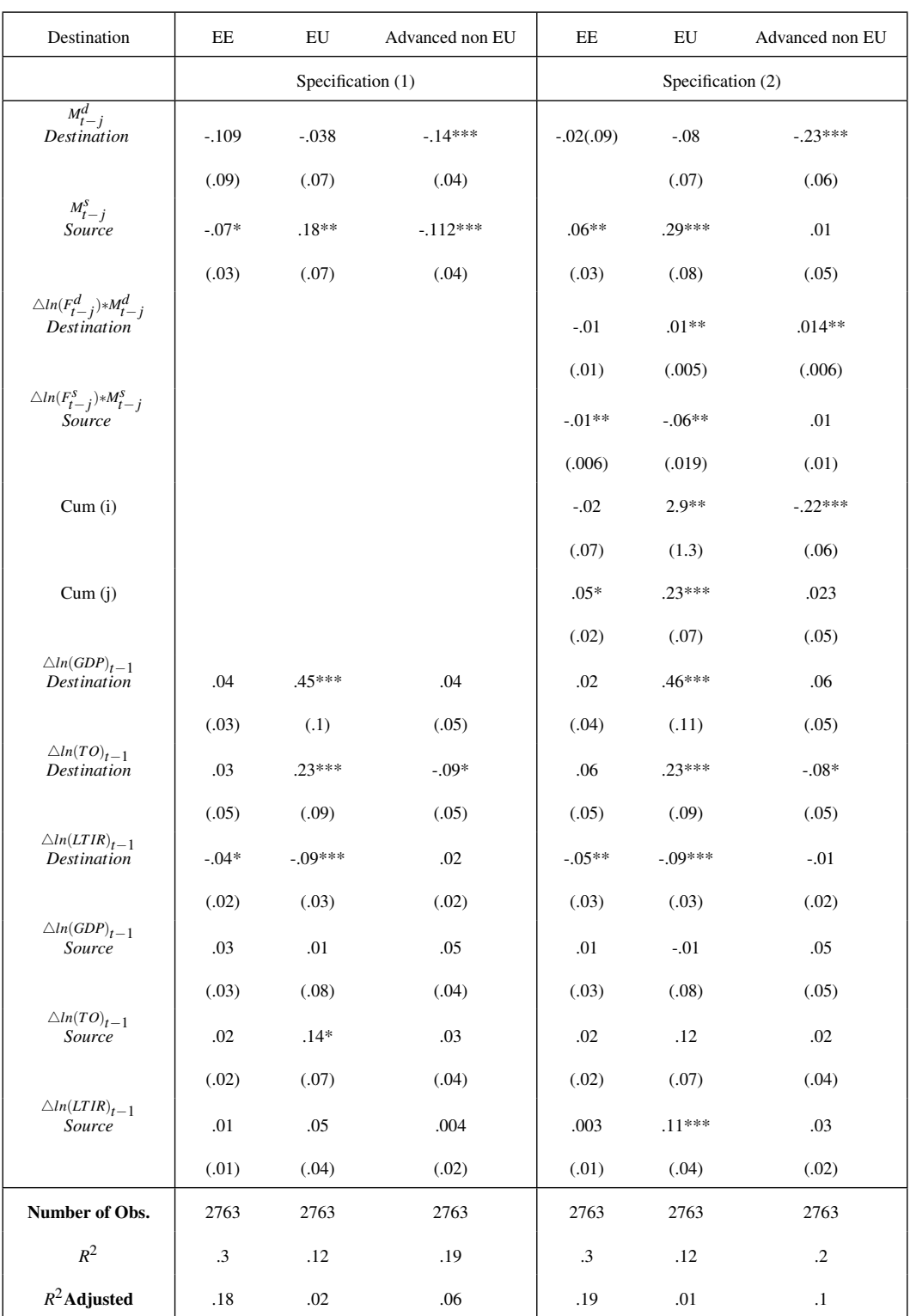

Note: The dependent variable is the growth of bilateral cross-border credit from Advanced non eurozone Countries (Source Countries) to the Emerging, Eurozone and Advanced non-Eurozone countries. (1) reports the cumulative effect of stand alone macroprudential policies and control variables on bilateral cross-border credit. (2) extends (1) by including the cumulative effect of the interaction between macroprudential instrument and financial vulnerability variable for destination and source countries. In each specification we consider a country and a time fixed effects. $M$ is capital to asset ratio macroprudential tool. $d$ is the destination countries and $s$ is the source countries. There 34 destination countries and 15 source countries. TO is trade openness. LTIR is the long term interest rate. $*^{* * *}, * * *, *$ indicate results significant at the $1 \%, 5 \%$ and $10 \%$ level respectively. Standard errors are in (). 
Table B.4. Effects of LTV ratio on bilateral cross-border lending from Advanced non eurozone

\section{Countries}

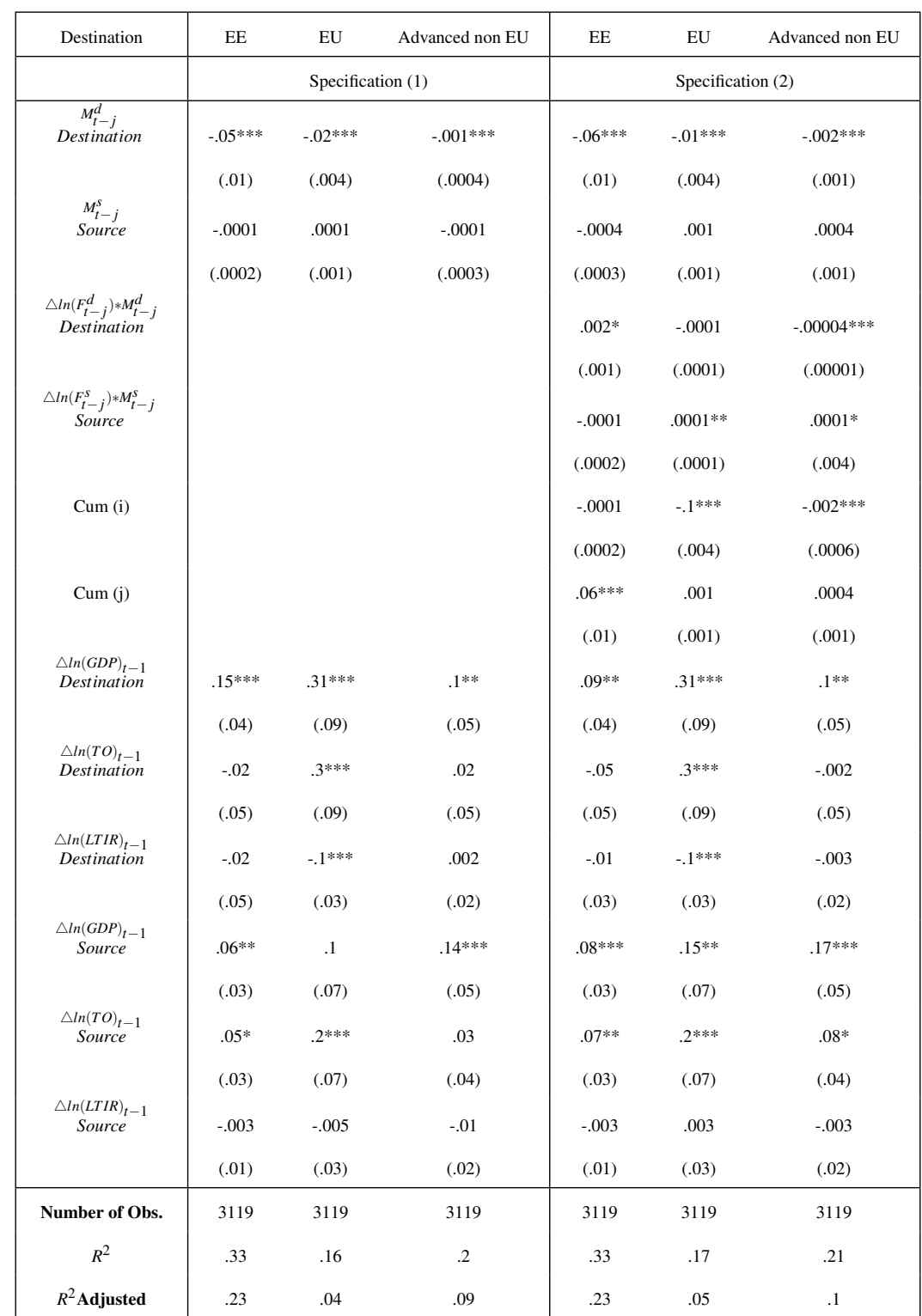

Note: The dependent variable is the growth of bilateral cross-border credit from Advanced non eurozone Countries (Source Countries) to the Emerging, Eurozone and Advanced non-Eurozone countries. (1) reports the cumulative effect of stand alone macroprudential policies and control variables on bilateral cross-border credit. (2) extends (1) by including the cumulative effect of the interaction between macroprudential instrument and financial vulnerability variable for destination and source countries.. In each specification we consider a country and a time fixed effects. $M$ is LTV ratio macroprudential tool measured as the ratio of household loan over the value of housing price. $d$ is the destination countries and $s$ is the source countries. There 34 destination countries and 15 source countries. TO is trade openness. LTIR is the long term interest rate. ***,***, indicate results significant at the $1 \%, 5 \%$ and $10 \%$ level respectively. Standard errors are in (). 
Table B.5. Effects of capital requirements on bilateral cross-border credit from Eurozone countries

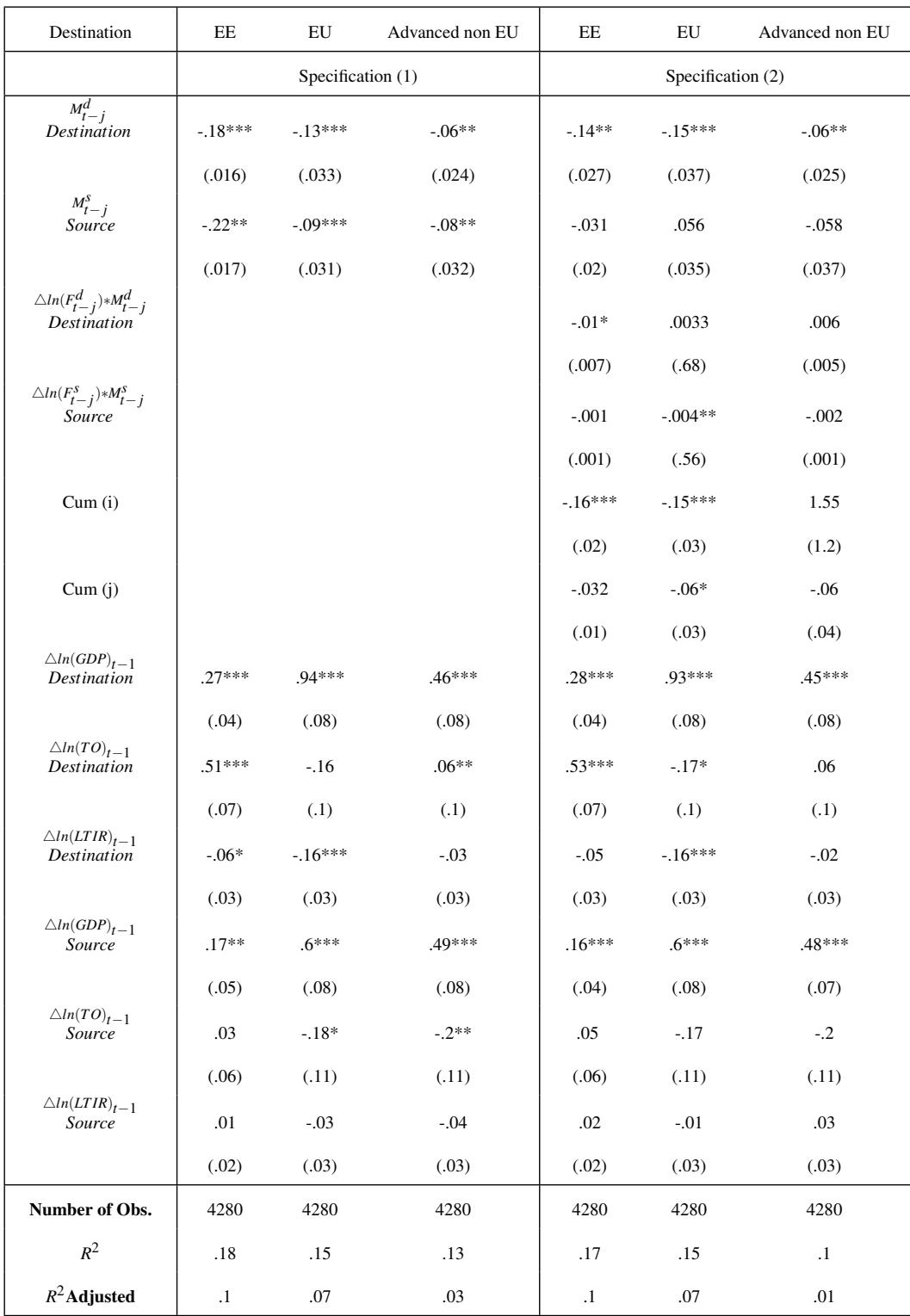

Note: The dependent variable is the growth of bilateral cross-border credit from Eurozone Countries (Source Countries) to the Emerging, Eurozone and Advanced non-Eurozone countries. (1) reports the cumulative effect of stand alone macroprudential policies and control variables on bilateral cross-border credit. (2) extends (1) by including the cumulative effect of the interaction between macroprudential instrument and financial vulnerability variable for destination and source countries. In each specification we consider a country and a time fixed effects. $M$ is a dummy capital requirement macroprudential tool. $d$ is the destination countries and $s$ is the source countries. There 34 destination countries and 15 source countries. TO is trade openness. LTIR is the long term interest rate. $* * *, * *, *$ indicate results significant at the $1 \%, 5 \%$ and $10 \%$ level respectively. Standard errors are in (). 
Table B.6. Effects of LTV ratio on bilateral cross-border credit from Eurozone countries

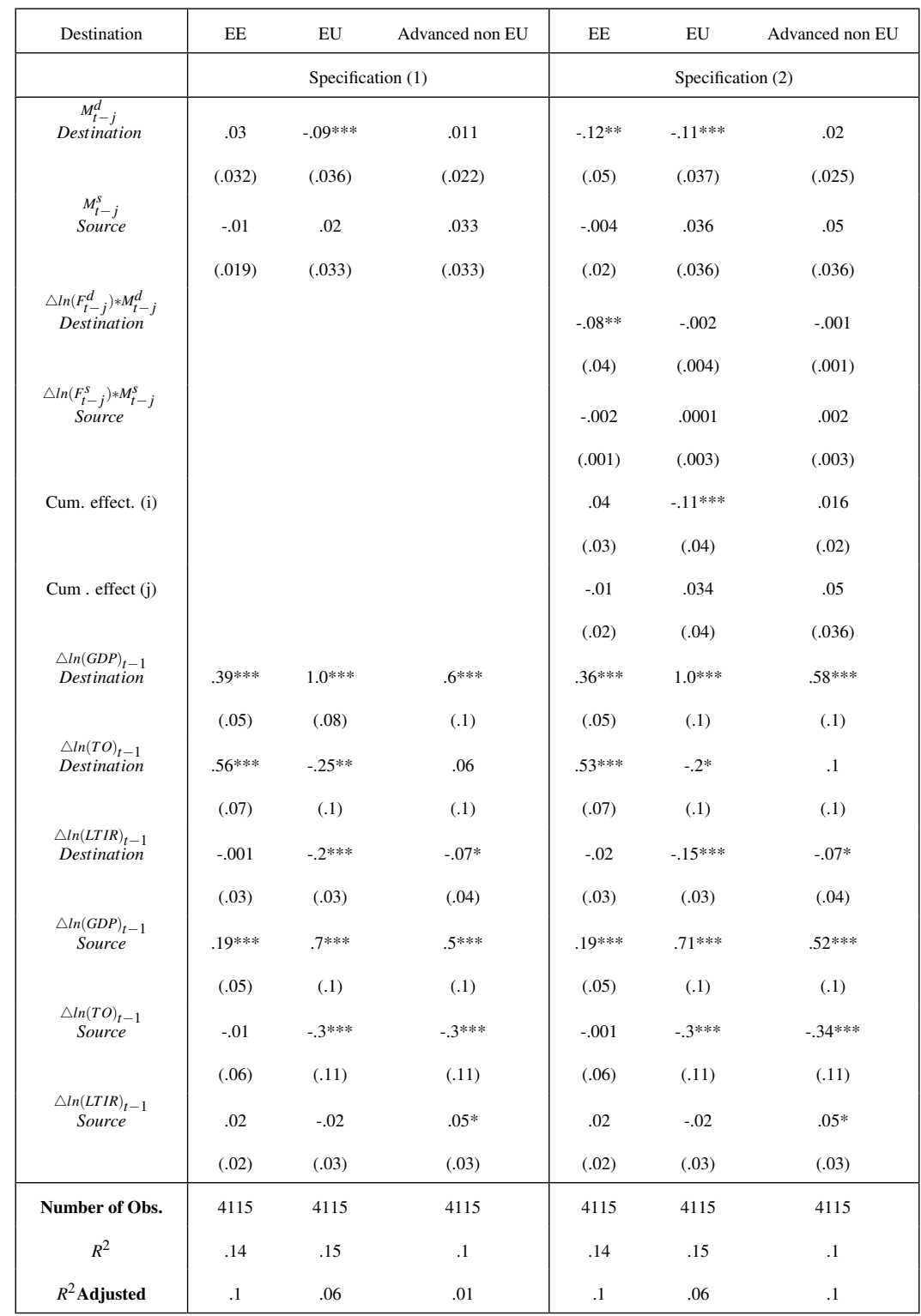

Note: The dependent variable is the growth of bilateral cross-border credit from Eurozone Countries (Source Countries) to the Emerging, Eurozone and Advanced non-Eurozone countries. (1) reports the cumulative effect of stand alone macroprudential policies and control variables on bilateral cross-border credit. (2) extends (1) by including the cumulative effect of the interaction between macroprudential instrument and financial vulnerability variable for destination and source countries. In each specification we consider a country and a time fixed effects. $M$ is a dummy LTV ratio macroprudential tool. $d$ is the destination countries and $s$ is the source countries. There 34 destination countries and 15 source countries. TO is trade openness. LTIR is the long term interest rate. $* * *, * *, *$ indicate results significant at the $1 \%, 5 \%$ and $10 \%$ level respectively. Standard errors are in (). 
Table B.7. Effects of capital to asset ratio on bilateral cross-border credit from Eurozone countries

\begin{tabular}{|c|c|c|c|c|c|c|}
\hline Destination & $\mathrm{EE}$ & $\mathrm{EU}$ & Advanced non EU & $\mathrm{EE}$ & $\mathrm{EU}$ & Advanced non EU \\
\hline & \multicolumn{3}{|c|}{ Specification (1) } & \multicolumn{3}{|c|}{ Specification (2) } \\
\hline $\begin{array}{c}M_{t-j}^{d} \\
\text { Destination }\end{array}$ & $-.28 * * * *$ & $-.16^{*}$ & -.026 & $-.4 * *$ & $-.18 *$ & -.01 \\
\hline & (.013) & $(.09)$ & (.09) & (.14) & $(.103)$ & (.09) \\
\hline $\begin{array}{l}M_{t-j}^{S} \\
\text { Source }\end{array}$ & $-.32 * * *$ & $-.63 * * *$ & $-.475^{* * * *}$ & $-.3 * * *$ & $.6 * * *$ & $-.46^{* * * *}$ \\
\hline & $(.06)$ & (.13) & (.11) & $(.06)$ & (.14) & (.12) \\
\hline $\begin{array}{c}\Delta l n\left(F_{t-j}^{d}\right) * M_{t-j}^{d} \\
\text { Destination }\end{array}$ & & & & .01 & .005 & . 001 \\
\hline & & & & $(.03)$ & $(.01)$ & $(.01)$ \\
\hline $\begin{array}{c}\Delta \ln \left(F_{t-j}^{S}\right) * M_{t-j}^{S} \\
\text { Source }\end{array}$ & & & & .003 & 1.5 & . 001 \\
\hline & & & & $(.002)$ & (1.6) & (.004) \\
\hline Cum (i) & & & & $-.33^{* * * *}$ & $-.18 *$ & -.01 \\
\hline & & & & (.13) & (.1) & (.09) \\
\hline Cum (j) & & & & $.35 * * *$ & $-.6 * *$ & $-.46^{* * * *}$ \\
\hline & & & & $(.0)$ & (.14) & (.12) \\
\hline $\begin{array}{l}\Delta \ln (G D P)_{t-1} \\
\text { Destination }\end{array}$ & $.15^{* * * *}$ & $1.1 * * *$ & .11 & $.18^{* * * *}$ & $1.02^{* * * *}$ & .11 \\
\hline & $(.06)$ & (.13) & (.1) & $(.06)$ & (.13) & (.09) \\
\hline $\begin{array}{l}\Delta l n(T O)_{t-1} \\
\text { Destination }\end{array}$ & -.04 & $-.4 * * *$ & -.01 & .11 & $-.4 * * *$ & -.01 \\
\hline & (.08) & (.12) & (.09) & (.1) & (.12) & (.09) \\
\hline $\begin{array}{l}\Delta \ln (L T I R)_{t-1} \\
\text { Destination }\end{array}$ & -.01 & $-.1 * * *$ & $.09^{* *}$ & .01 & $-.1 * * *$ & $.1^{* * *}$ \\
\hline & (.04) & (.04) & (.04) & $(.04)$ & (.04) & (.04) \\
\hline $\begin{array}{c}\Delta \ln (G D P)_{t-1} \\
\text { Source }\end{array}$ & $.13^{* *}$ & $.5 * * *$ & .07 & $.13^{* * *}$ & $.5 * * *$ & .08 \\
\hline & $(.06)$ & (.13) & (.11) & $(.06)$ & (.13) & (.11) \\
\hline $\begin{array}{l}\Delta \ln (T O)_{t-1} \\
\text { Source }\end{array}$ & $.11^{* *}$ & $-.4 * * *$ & $-.25^{* * *}$ & $-.1 *$ & $-.4 * * *$ & $-.24 * *$ \\
\hline & $(.06)$ & (.12) & (.11) & $(.05)$ & (.12) & (.11) \\
\hline $\begin{array}{l}\Delta \ln (\text { LTIR })_{t-1} \\
\text { Source }\end{array}$ & -.02 & $-.08 * *$ & .03 & -.02 & $-.08 * *$ & .03 \\
\hline & $(.02)$ & $(.04)$ & (.03) & $(.02)$ & (.04) & $(.03)$ \\
\hline Number of Obs. & 2763 & 2763 & 2763 & 2763 & 2763 & 2763 \\
\hline$R^{2}$ & .19 & .15 & .15 & .21 & .15 & .16 \\
\hline$R^{2}$ Adjusted & .07 & .02 & .02 & .08 & .02 & .03 \\
\hline
\end{tabular}

Note: The dependent variable is the growth of bilateral cross-border credit from Eurozone Countries (Source Countries) to the Emerging, Eurozone and Advanced non-Eurozone countries. (1) reports the cumulative effect of stand alone macroprudential policies and control variables on bilateral cross-border credit. (2) extends (1) by including the cumulative effect of the interaction between macroprudential instrument and financial vulnerability variable for destination and source countries. In each specification we consider a country and a time fixed effects. $M$ is capital to asset ratio macroprudential tool. $d$ is the destination countries and $s$ is the source countries. There 34 destination countries and 15 source countries. TO is trade openness. LTIR is the long term interest rate. $* * * * * * *$ indicate results significant at the $1 \%, 5 \%$ and $10 \%$ level respectively. Standard errors are in () 
Table B.8. Effects of LTV ratio on bilateral cross-border lending from Eurozone Countries

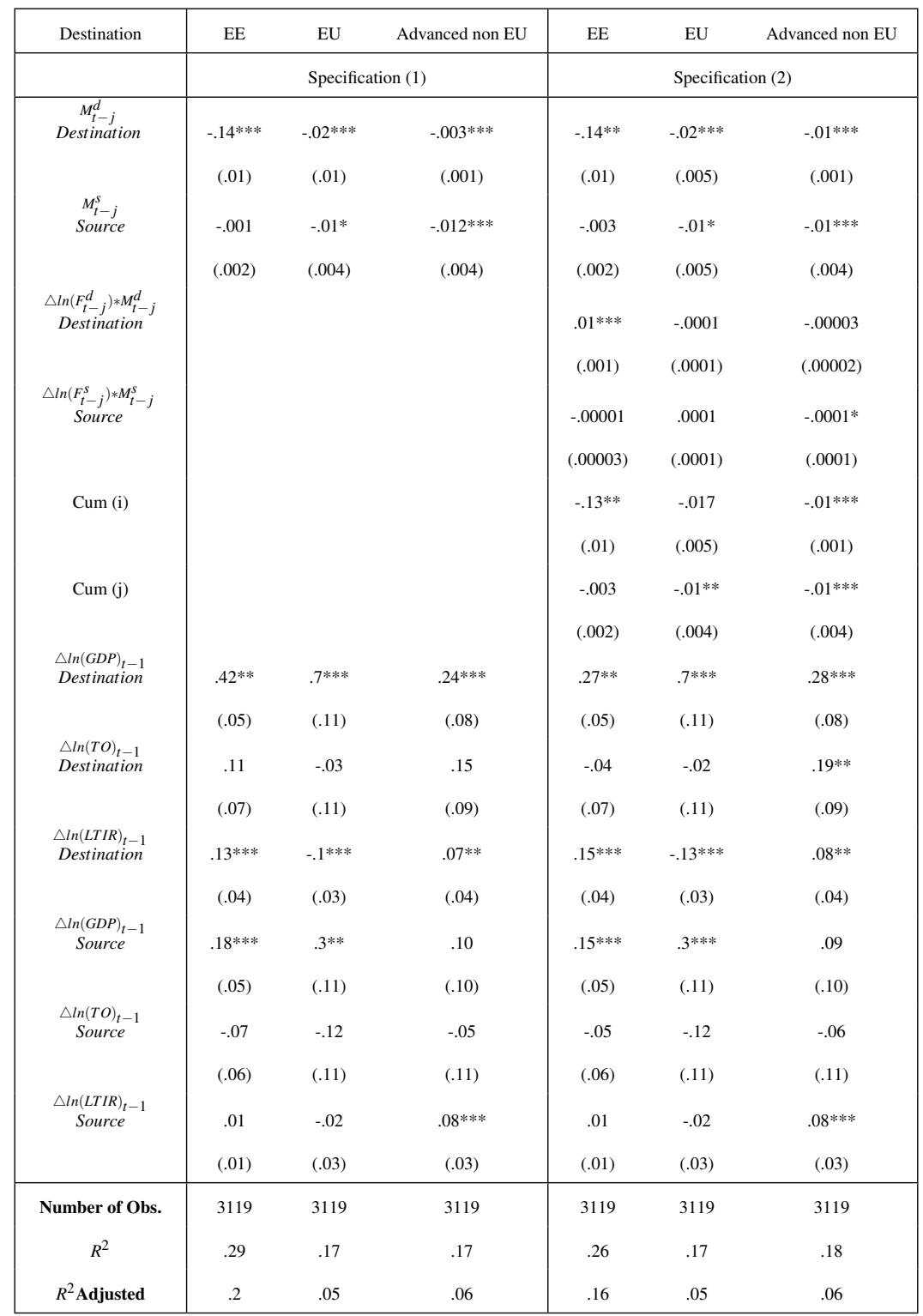

Note: The dependent variable is the growth of bilateral cross-border credit from Eurozone Countries (Source Countries) to the Emerging, Eurozone and Advanced non-Eurozone countries. (1) reports the cumulative effect of stand alone macroprudential policies and control variables on bilateral cross-border credit. (2) extends (1) by including the cumulative effect of the interaction between macroprudential instrument and financial vulnerability variable for destination and source countries.. In each specification we consider a country and a time fixed effects. $M$ is LTV ratio macroprudential tool measured as the ratio of household loan over the value of housing price. $d$ is the destination countries and $s$ is the source countries. There 34 destination countries and 15 source countries. TO is trade openness. LTIR is the long term interest rate. $* * * * * * *$ indicate results significant at the $1 \%, 5 \%$ and $10 \%$ level respectively. Standard errors are in $(0$. 


\section{Appendix C: Figures-Chapter 3}

\section{Figure A- Productivity shock}
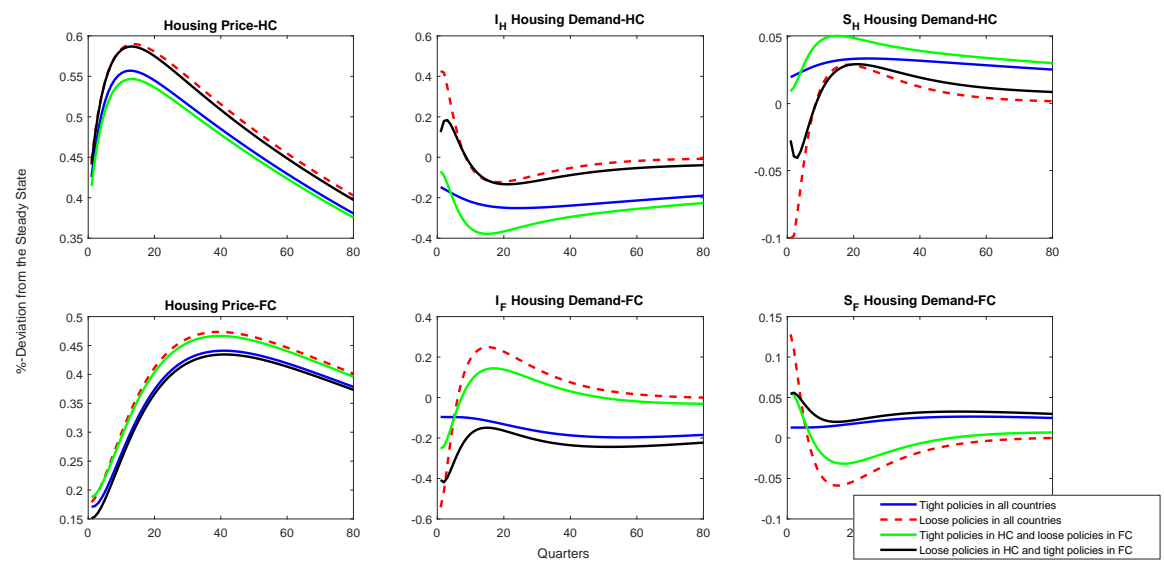

Note: Impulse responses to a one standard deviation technology shock in the home country. Solid blue line: Tight policies in all countries. Solid red line: Loose policies in all countries. Dashed blue line: Tight policies in the home country Loose policies in the foreign country. Dashed red line: Loose policies in the home country. Tight policies in the foreign country. Home (foreign) country is the first (second) row.

Figure B - Borrowing capacity shock
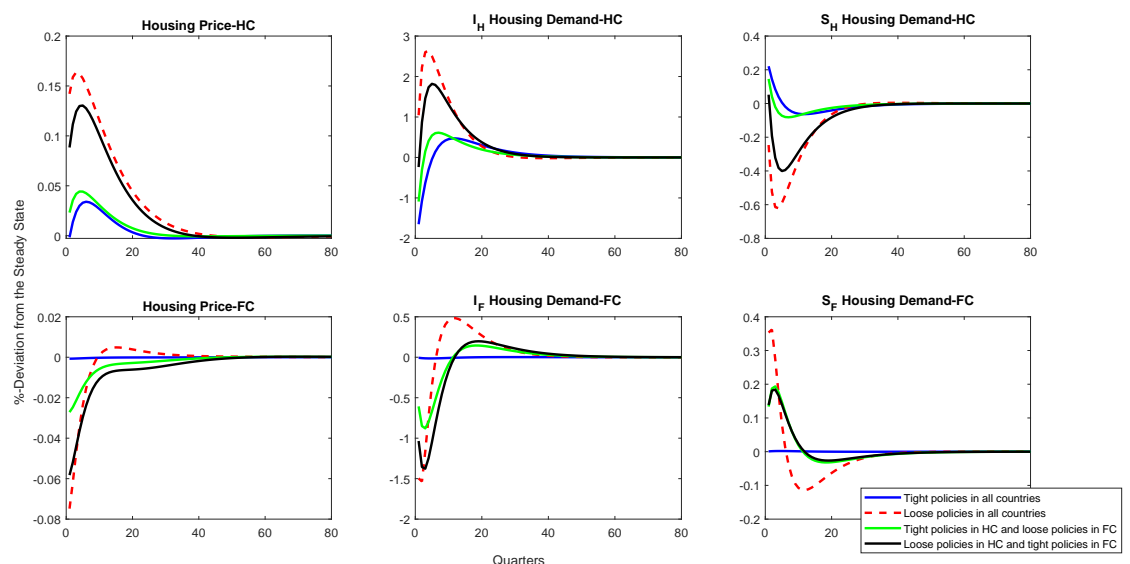

Note: Impulse responses to a one standard deviation borrowing capacity shock in the home country. Solid blue line: Tight policies in all countries. Solid red line: Loose policies in all countries. Dashed blue line: Tight policies in the home country Loose policies in the foreign country. Dashed red line: Loose policies in the home country. Tight policies in the foreign country. Home (foreign) country is the first (second) row. 
Figure C.1. Domestic productivity shock - LTV ratio
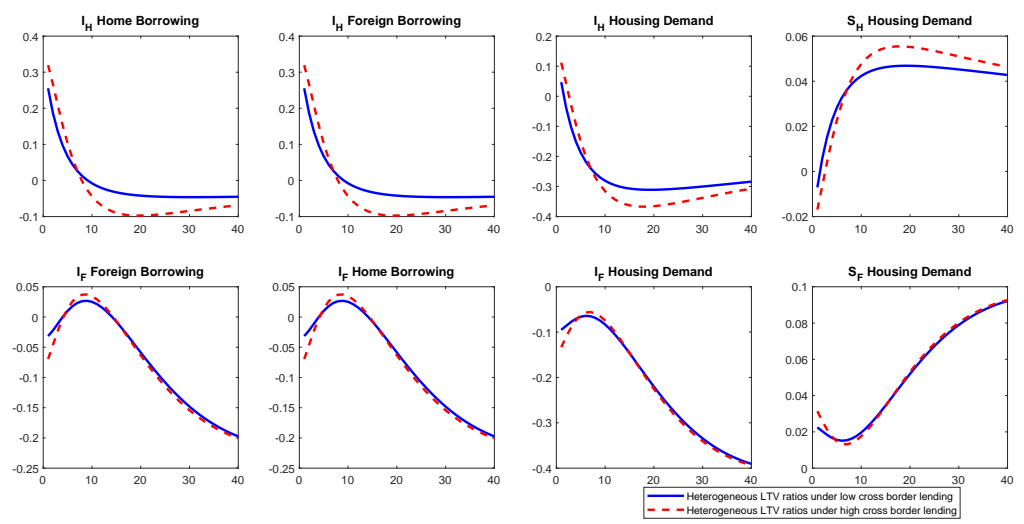

Note: Impulse responses to a one standard deviation technology shock in the home country. Blue solid : Heterogeneous LTV under low cross-border lending, Blue dashed : Heterogeneous LTV under high cross-border lending. Y asix: \%-Deviation from the steady state, $\mathrm{x}$ axis: Quarters.

Figure C.1.1: In this experiments, LTV ratios are active (time-varying) and Capital requirements are passive (constant) in both countries.
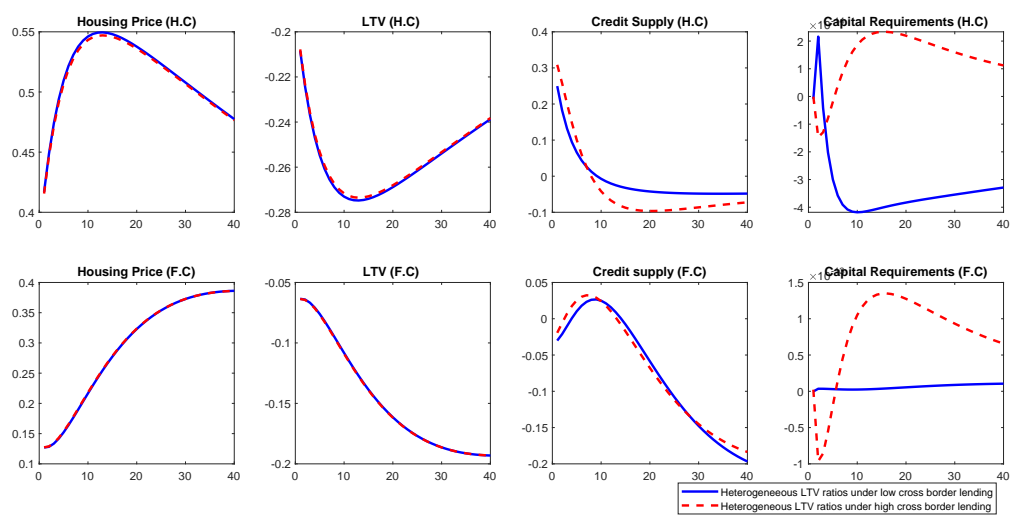

Note: Impulse responses to a one standard deviation technology shock in the home country. Blue solid : Heterogeneous LTV under low cross-border lending, Red dashed line : Heterogeneous LTV under high cross-border lending. $\mathrm{Y}$ asix: \%-Deviation from the steady state, $\mathrm{x}$ axis: Quarters.

Figure C.1.2: In this experiments, LTV ratios are active (time-varying) and Capital requirements are passive (constant) in both countries. 

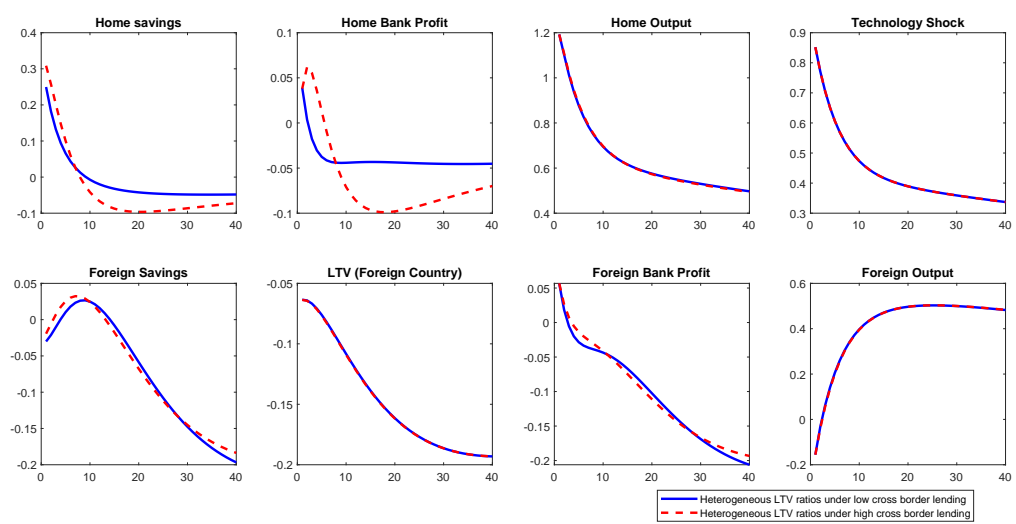

Note: Impulse responses to a one standard deviation technology shock in the home country. Blue solid : Heterogeneous LTV under low cross-border lending, Red dashed line: Heterogeneous LTV under high cross-border lending. $\mathrm{Y}$ asix: \%-Deviation from the steady state, $\mathrm{x}$ axis: Quarters.

Figure C.1.3: In this experiments, LTV ratios are active (time-varying) and Capital requirements are passive (constant) in both countries.
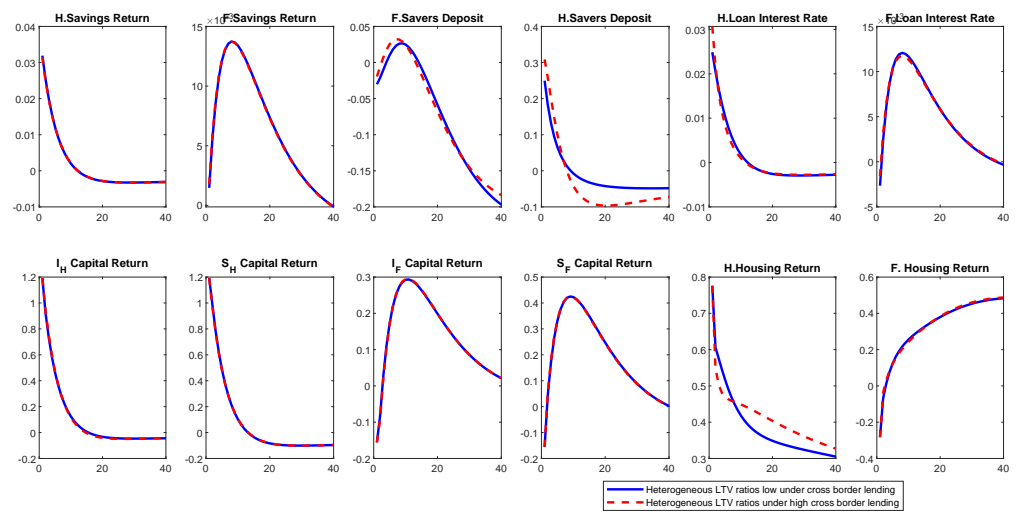

Note: Impulse responses to a one standard deviation technology shock in the home country. Blue solid : Heterogeneous LTV under low cross-border lending, Red dashed lin: Heterogeneous LTV under high cross-border lending. $Y$ asix: \%-Deviation from the steady state, $x$ axis: Quarters.

Figure C.1.4: In this experiments, LTV ratios are active (time-varying) and Capital requirements are passive (constant) in both countries. 

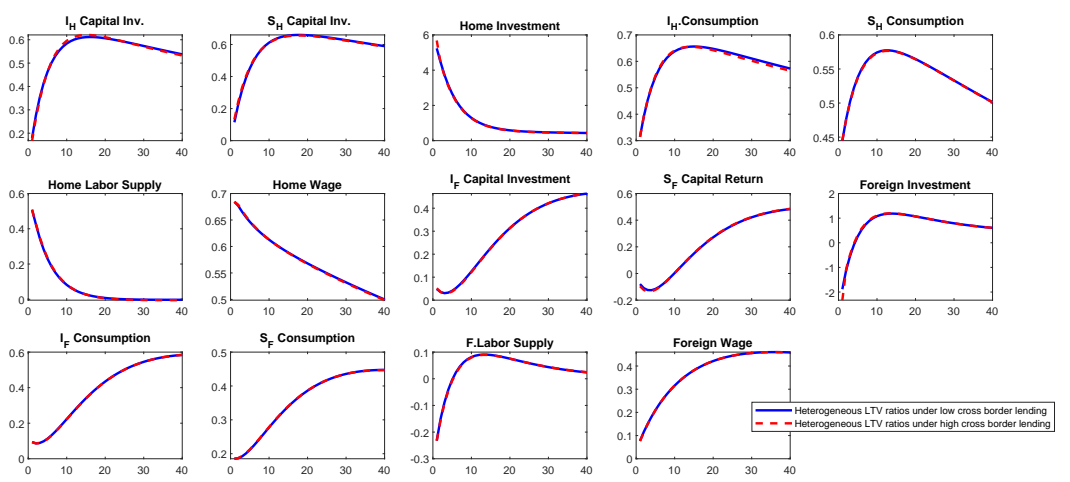

Note: Impulse responses to a one standard deviation technology shock in the home country. Blue solid : Heterogeneous LTV under low cross-border lending, Red dashed line: Heterogeneous LTV under high cross-border lending. Y asix: \%-Deviation from the steady state, $\mathrm{x}$ axis: Quarters.

Figure C.1.5: In this experiments, LTV ratios are active (time-varying) and Capital requirements are passive (constant) in both countries. 
Figure C.2. Domestic productivity shock - Capital requirements
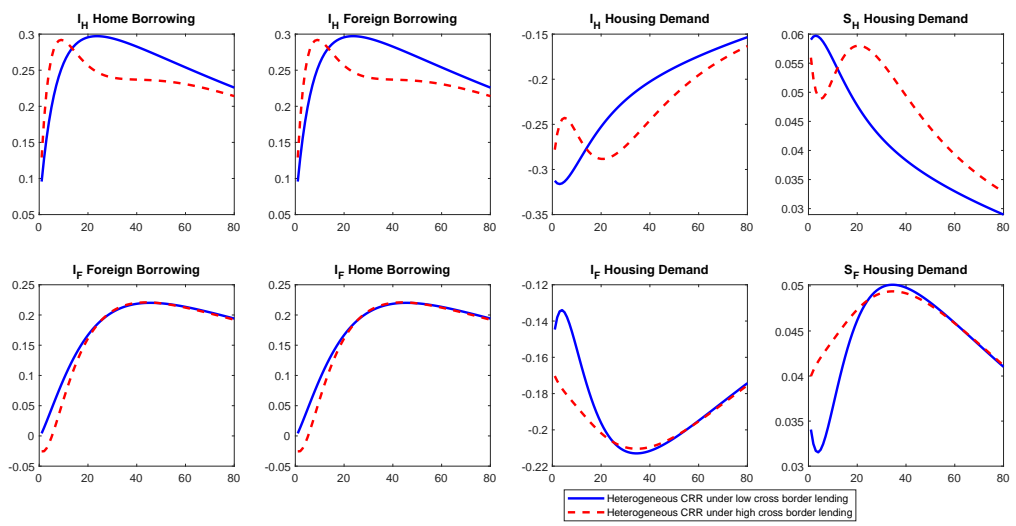

Note: Impulse responses to a one standard deviation technology shock in the home country. Blue solid : Heterogeneous capital requirements under low cross-border lending, Red dashed lin: Heterogeneous capital requirements under high cross-border lending. Y asix: \% -Deviation from the steady state, $\mathrm{x}$ axis: Quarters.

Figure C.2.1 In this case, LTV ratios are passive (constant) and Capital requirements are active (time-varying) in both countries.
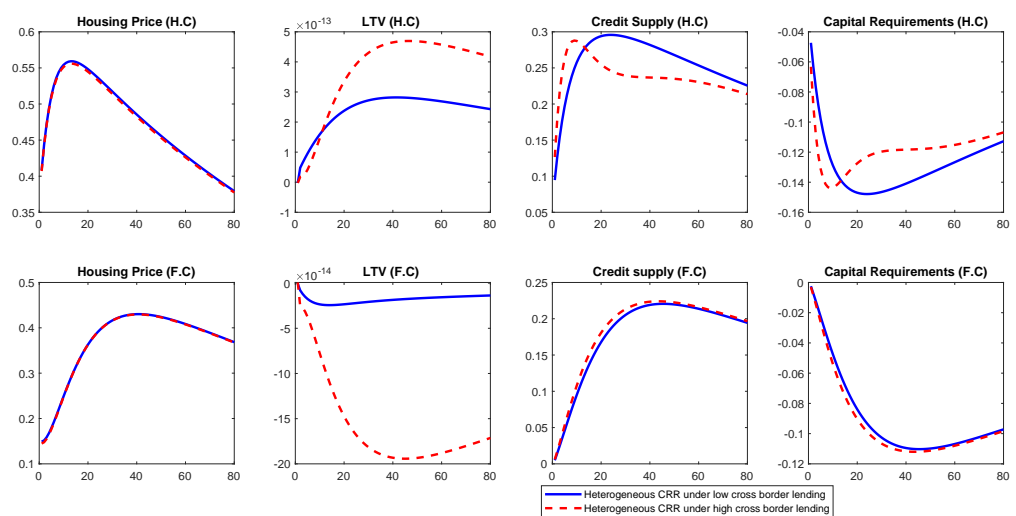

Note: Impulse responses to a one standard deviation technology shock in the home country. Blue solid : Heterogeneous capital requirements under low cross-border lending, Red dashed lin: Heterogeneous capital requirements under high cross-border lending. $\mathrm{Y}$ asix: \%Deviation from the steady state, $\mathrm{x}$ axis: Quarters.

Figure C.2.2 In this case, LTV ratios are passive (constant) and Capital requirements are active (time-varying) in both countries. 

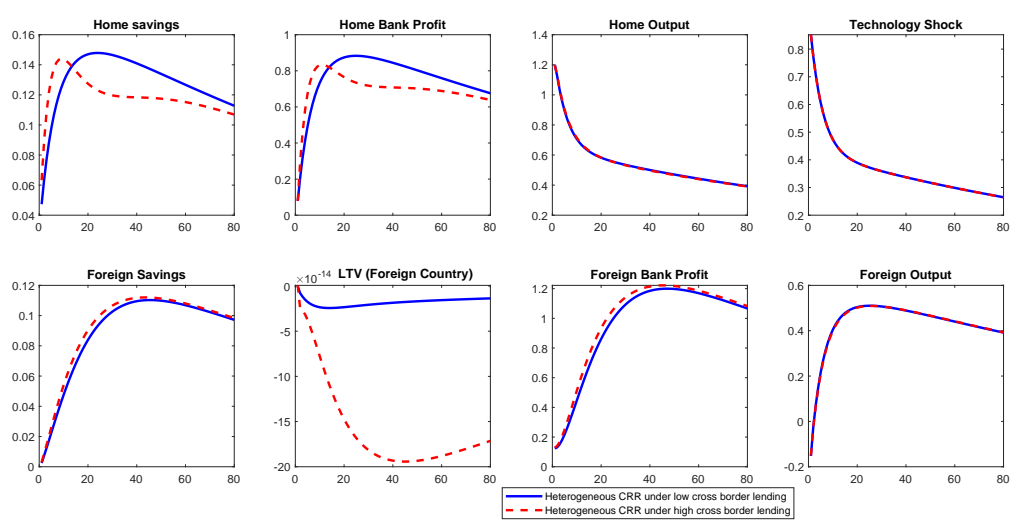

Note: Impulse responses to a one standard deviation technology shock in the home country. Blue solid : Heterogeneous capital requirements under low cross-border lending, Red dashed lin: Heterogeneous capital requirements under high cross-border lending. $\mathrm{Y}$ asix: \%Deviation from the steady state, $\mathrm{x}$ axis: Quarters.

Figure C.2.3 In this case, LTV ratios are passive (constant) and Capital requirements are active (time-varying) in both countries.
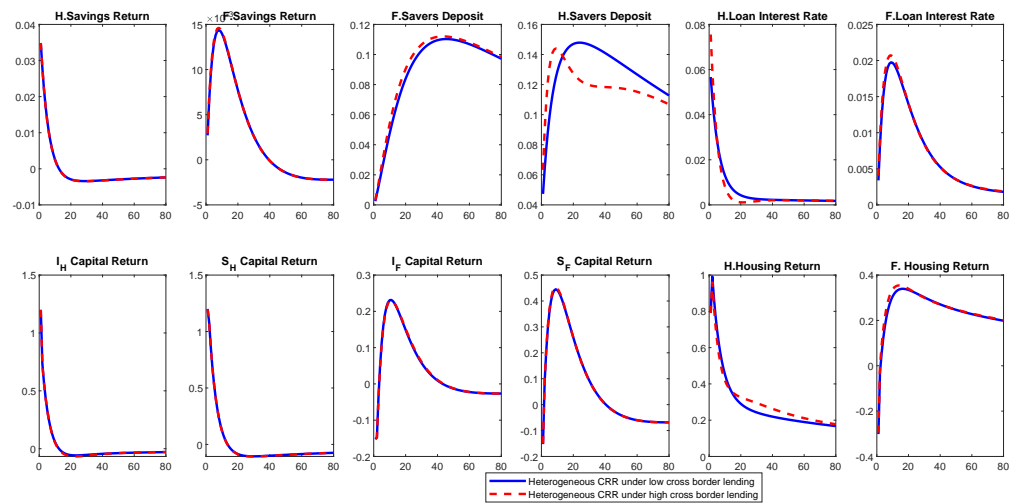

Note: Impulse responses to a one standard deviation technology shock in the home country. Blue solid : Heterogeneous capital requirements under low cross-border lending, Red dashed lin: Heterogeneous capital requirements under high cross-border lending. Y asix: \%Deviation from the steady state, x axis: Quarters.

Figure C.2.4 In this case, LTV ratios are passive (constant) and Capital requirements are active (time-varying) in both countries. 

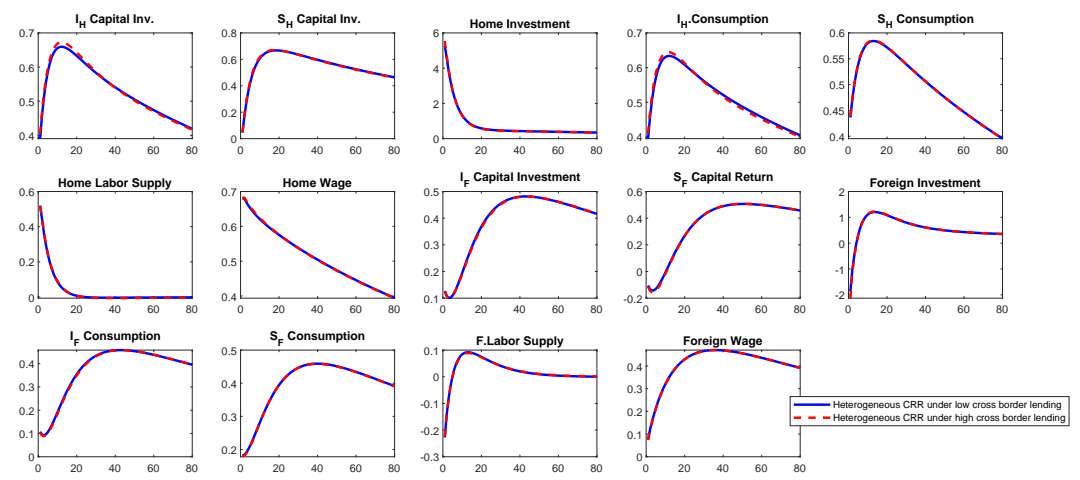

Note: Impulse responses to a one standard deviation technology shock in the home country. Blue solid : Heterogeneous capital requirements under low cross-border lending, Red dashed lin Heterogeneous capital requirements under high cross-border lending. Y asix: \%Deviation from the steady state, x axis: Quarters.

Figure C.2.5 In this case, LTV ratios are passive (constant) and Capital requirements are active (time-varying) in both countries. 
Figure C.3. Domestic borrowing capacity shock -LTV ratio
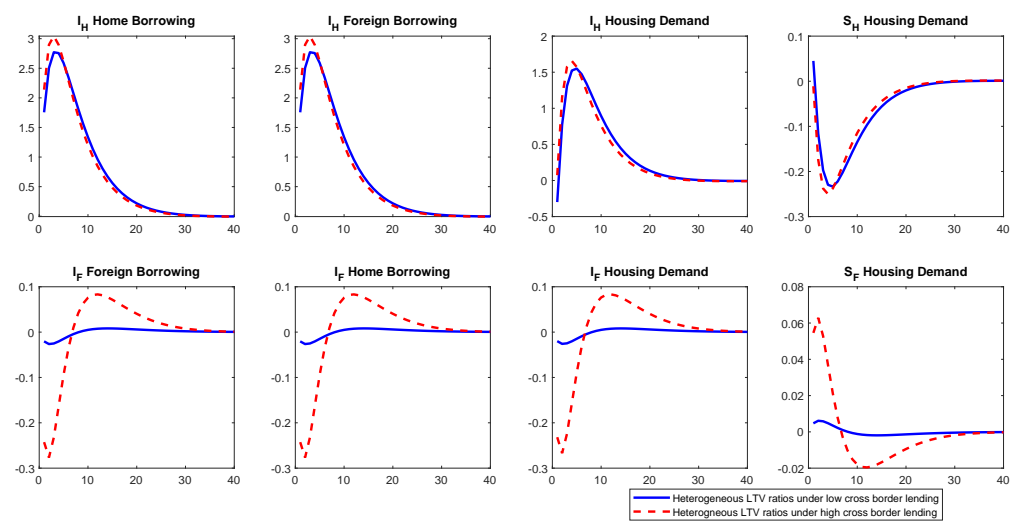

Note: Impulse responses to a one standard deviation borrowing capacity shock in the home country. Blue solid : Heterogeneous LTV under low cross-border lending. Red dashed line: Heterogeneous LTV under high cross-border lending. Y asix: \% Deviation from the steady state, $\mathrm{x}$ axis: Quarters.

Figure C.3.1: In this experiments, LTV ratios are active (time-varying) and Capital requirements are passive (constant) in both countries.
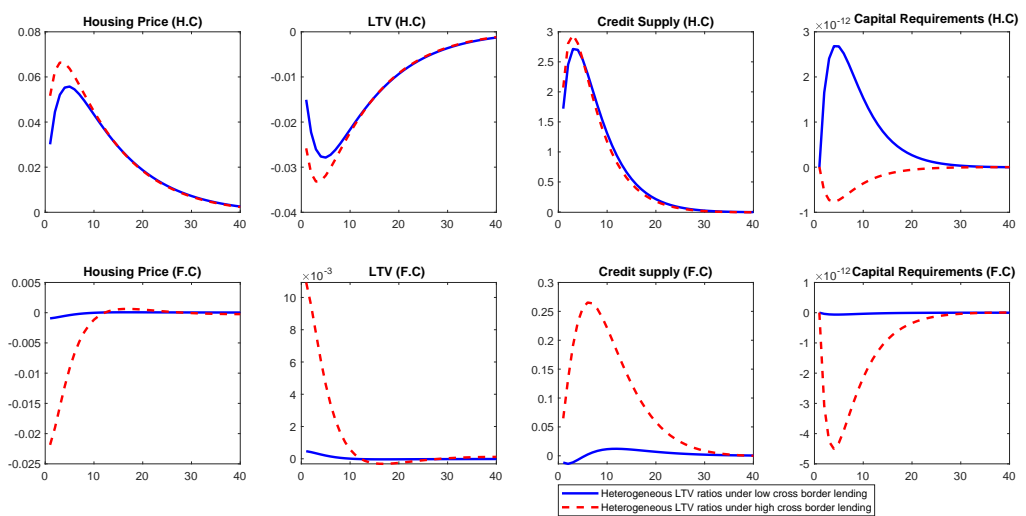

Note: Impulse responses to a one standard deviation borrowing capacity shock in the home country. Blue solid : Heterogeneous LTV under low cross-border lending. Red dashed lin: Heterogeneous LTV under high cross-border lending. Y asix: \%Deviation from the steady state, $\mathrm{x}$ axis: Quarters.

Figure C.3.2: In this experiments, LTV ratios are active (time-varying) and Capital requirements are passive (constant) in both countries. 

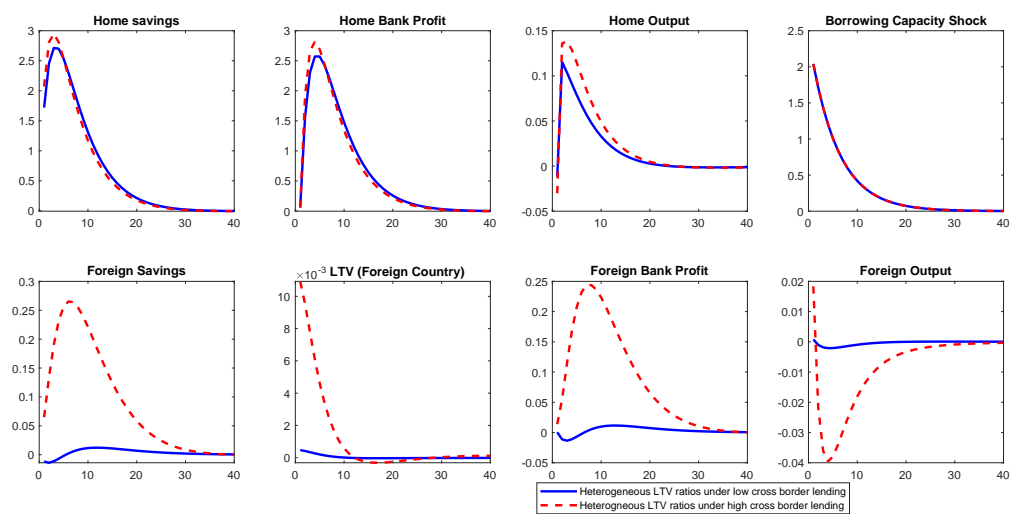

Note: Impulse responses to a one standard deviation borrowing capacity shock in the home country. Blue solid : Heterogeneous LTV under low cross-border lending. Red dashed lin: Heterogeneous LTV under high cross-border lending. $\mathrm{Y}$ asix: \%Deviation from the steady state, $\mathrm{x}$ axis: Quarters.

Figure C.3.3: In this experiments, LTV ratios are active (time-varying) and Capital requirements are passive (constant) in both countries.
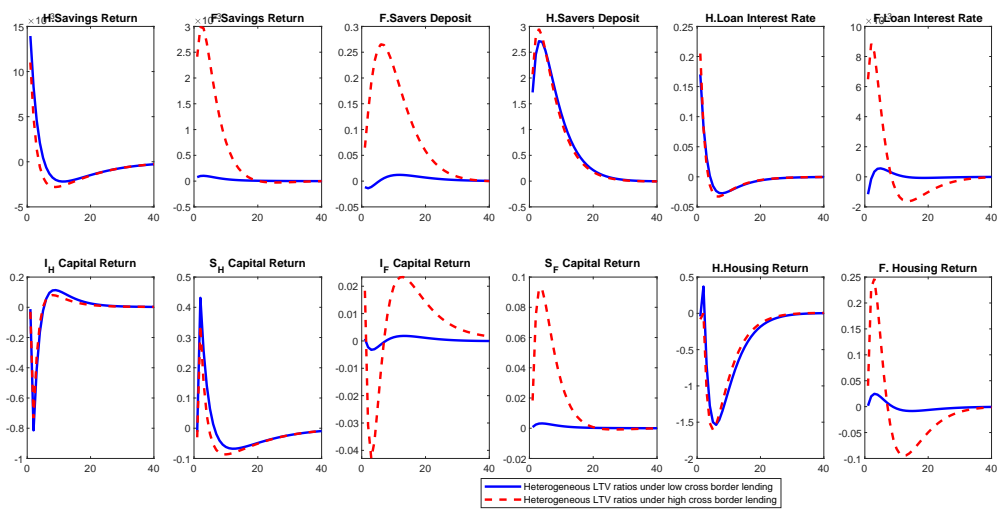

Note: Impulse responses to a one standard deviation borrowing capacity shock in the home country. Blue solid : Heterogeneous LTV under low cross-border lending. Red dashed lin: Heterogeneous LTV under high cross-border lending. Y asix: \%Deviation from the steady state, $\mathrm{x}$ axis: Quarters.

Figure C.3.4: In this experiments, LTV ratios are active (time-varying) and Capital requirements are passive (constant) in both countries. 

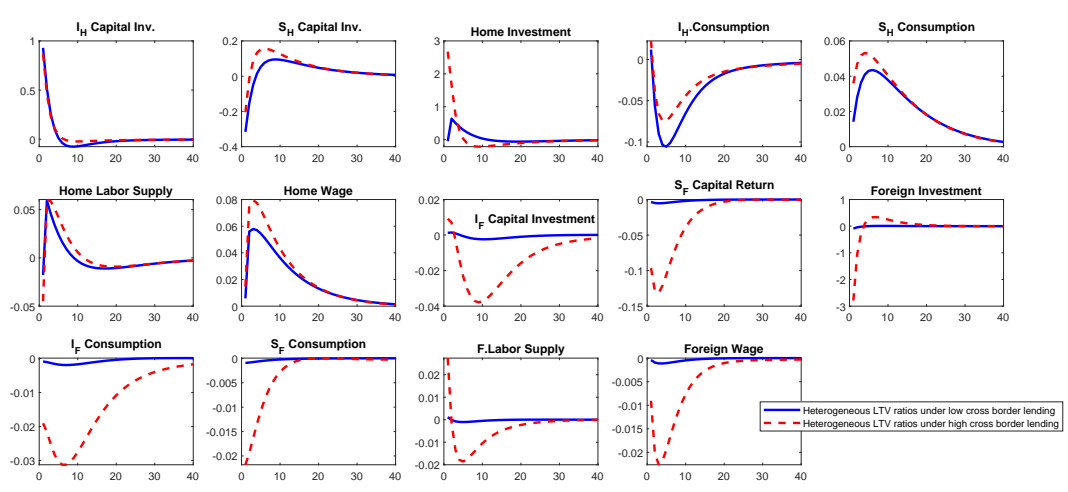

Note: Impulse responses to a one standard deviation borrowing capacity shock in the home country. Blue solid : Heterogeneous LTV under low cross-border lending. Red dashed lin: Heterogeneous LTV under high cross-border lending. Y asix: \%Deviation from the steady state, $\mathrm{x}$ axis: Quarters.

Figure C.3.5: In this experiments, LTV ratios are active (time-varying) and Capital requirements are passive (constant) in both countries. 
Figure C.4. Domestic borrowing capacity shock - Capital requirements
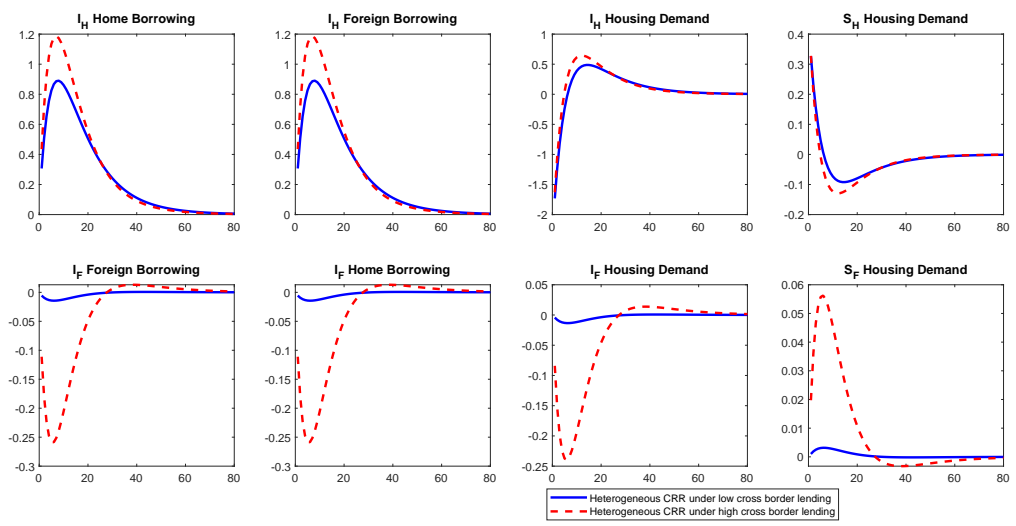

Note: Impulse responses to a one standard deviation borrowing capacity shock in the home country. Blue solid : Heterogeneous capital requirements under low cross-border lending, Red dashed line: Heterogeneous capital requirements under high cross-border lending $\mathrm{Y}$ asix: \%Deviation from the steady state, $\mathrm{x}$ axis: Quarters.

Figure C.4.1: In this experiments, LTV ratios are passive (constant) and Capital requirements are active (time-varying) in both countries.
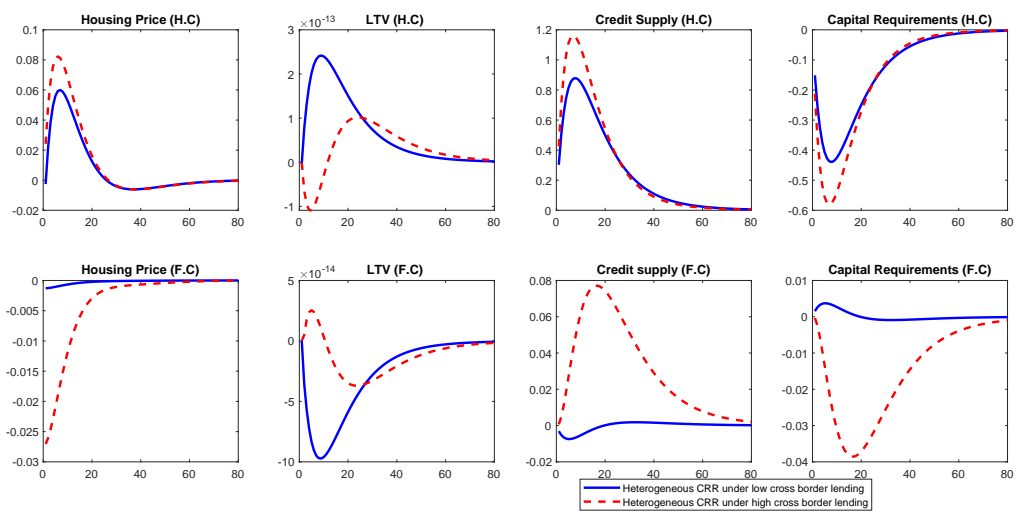

Note: Impulse responses to a one standard deviation borrowing capacity shock in the home country. Blue solid : Heterogeneous capital requirements under low cross-border lending, Red dashed line: Heterogeneous capital requirements under high cross-border lending. Y asix: \%Deviation from the steady state, $\mathrm{x}$ axis: Quarters.

Figure C.4.2: In this experiments, LTV ratios are passive (constant) and Capital requirements are active (time-varying) in both countries. 

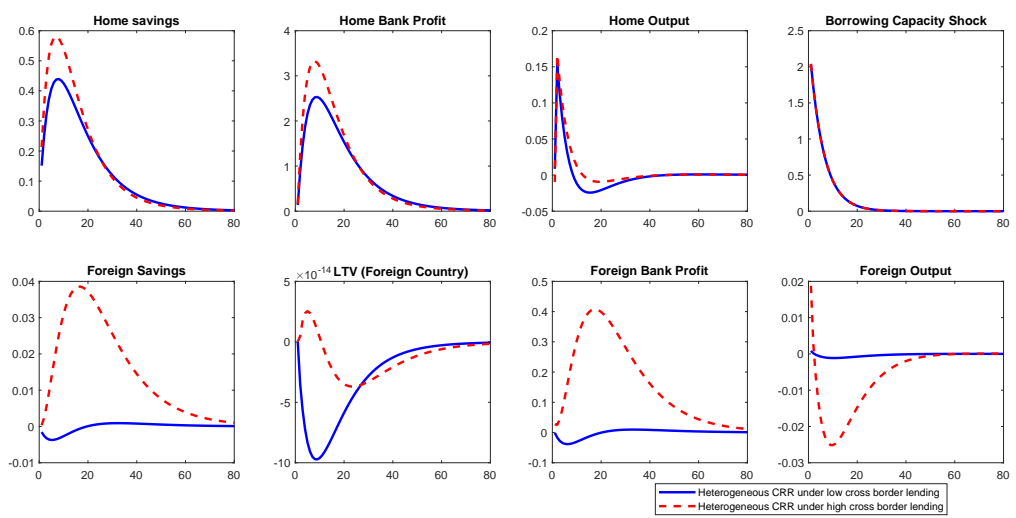

Note: Impulse responses to a one standard deviation borrowing capacity shock in the home country. Blue solid : Heterogeneous capital requirements under low cross-border lending, Red dashed line: Heterogeneous capital requirements under high cross-border lending. Y asix: \%Deviation from the steady state, $\mathrm{x}$ axis: Quarters.

Figure C.4.3: In this experiments, LTV ratios are passive (constant) and Capital requirements are active (time-varying) in both countries.
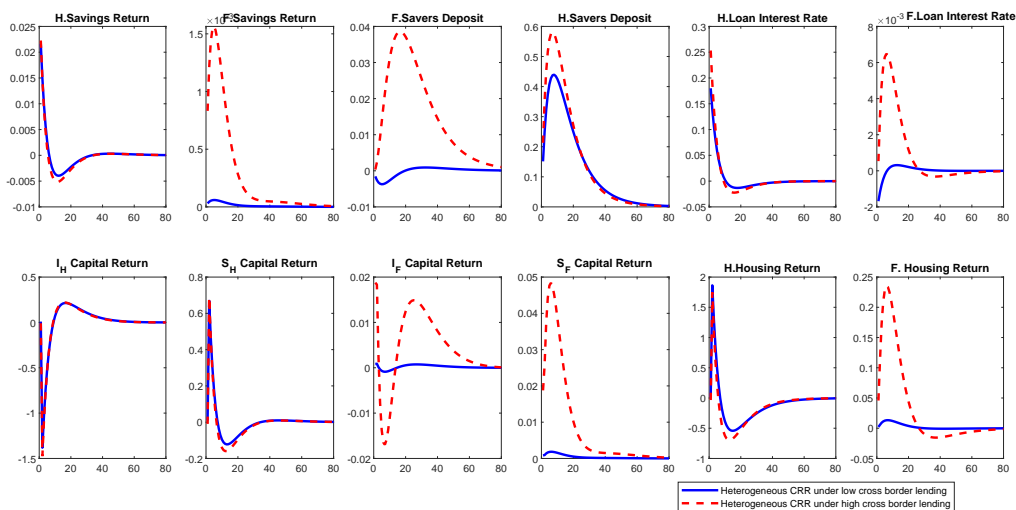

Note: Impulse responses to a one standard deviation borrowing capacity shock in the home country. Blue solid : Heterogeneous capital requirements under low cross-border lending, Red dashed line: Heterogeneous capital requirements under high cross-border lending.

Figure C.4.4: In this experiments, LTV ratios are passive (constant) and Capital requirements are active (time-varying) in both countries. 

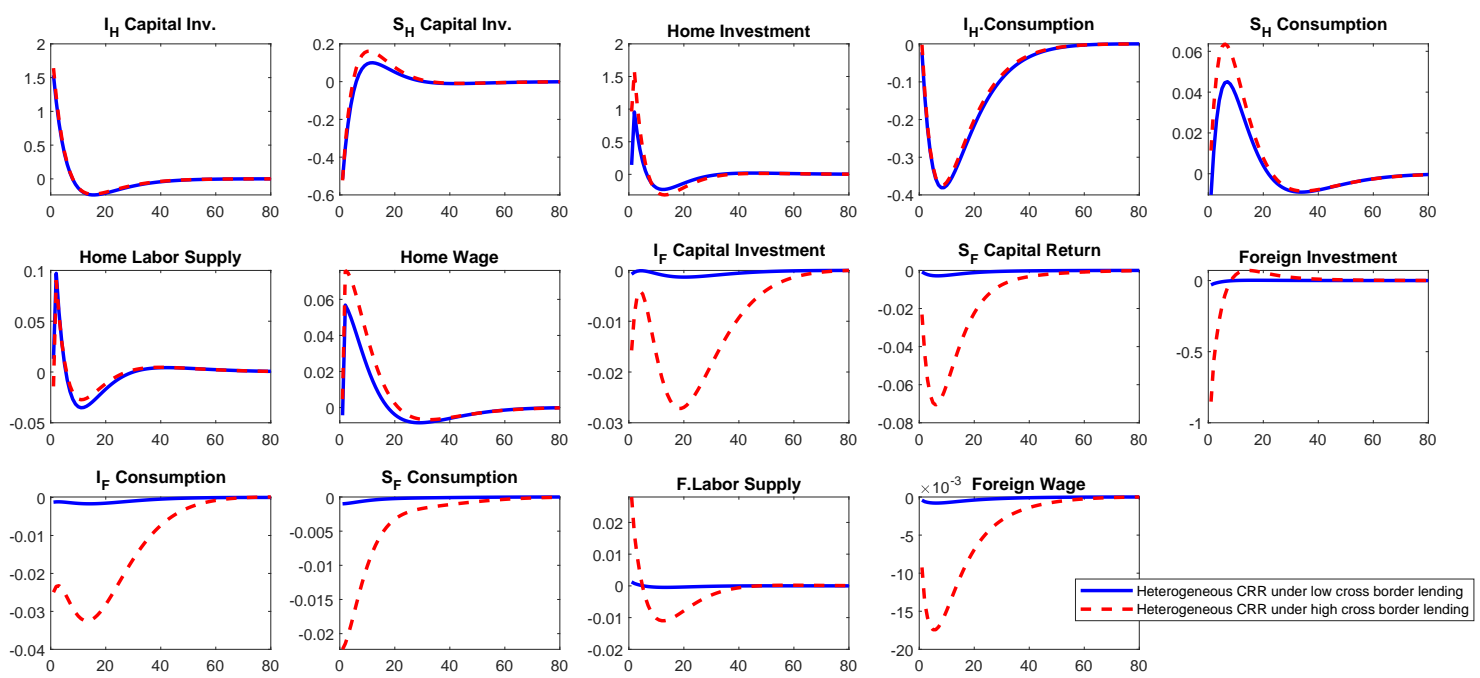

Note: Impulse responses to a one standard deviation borrowing capacity shock in the home country. Blue solid : Heterogeneous capital requirements under low cross-border lending, Red dashed line: Heterogeneous capital requirements under high cross-border lending. $\mathrm{Y}$ asix: \%Deviation from the steady state, $\mathrm{x}$ axis: Quarters.

Figure C.4.5: In this experiments, LTV ratios are passive (constant) and Capital requirements are active (time-varying) in both countries. 
Figure C.5. Domestic productivity shock
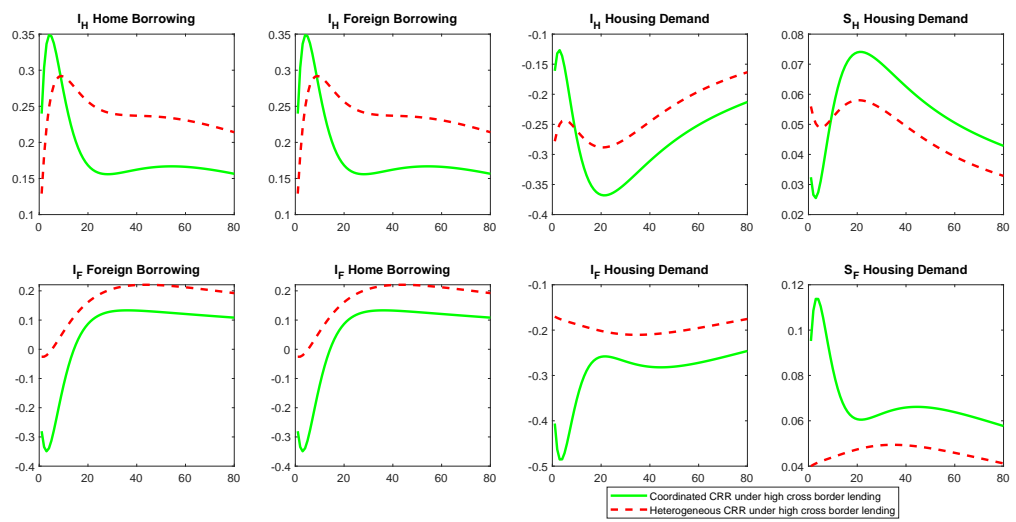

Note: Impulse responses to a one standard deviation technology shock in the home country. Green solid: coordinated capital requirements across countries under high cross border lending.. Red dashed line: Heterogeneous capital requirement under high cross-border lending, $\mathrm{Y}$ asix: \%Deviation from the steady state, $\mathrm{x}$ axis: Quarters.

Figure C.5. 1. International coordination of capital requirements (capital requirements are active and LTV ratios are constant)
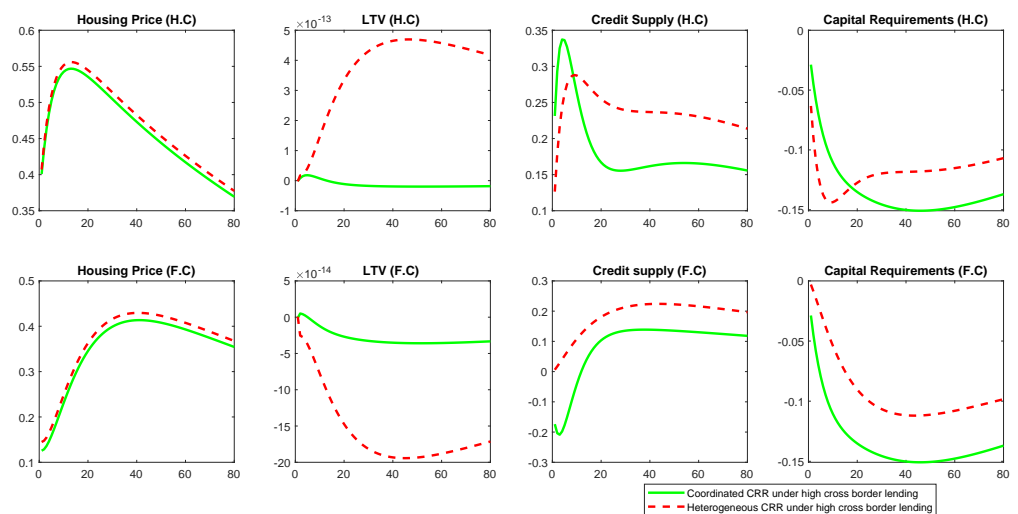

Note: Impulse responses to a one standard deviation technology shock in the home country. Green solid: coordinated capital requirements across countries under high cross border lending.. Red dashed line: Heterogeneous capital requirement under high cross-border lending, $\mathrm{Y}$ asix: \%Deviation from the steady state, $\mathrm{x}$ axis: Quarters.

Figure C.5. 2. International coordination of capital requirements (capital requirements are active and LTV ratios are constant) 

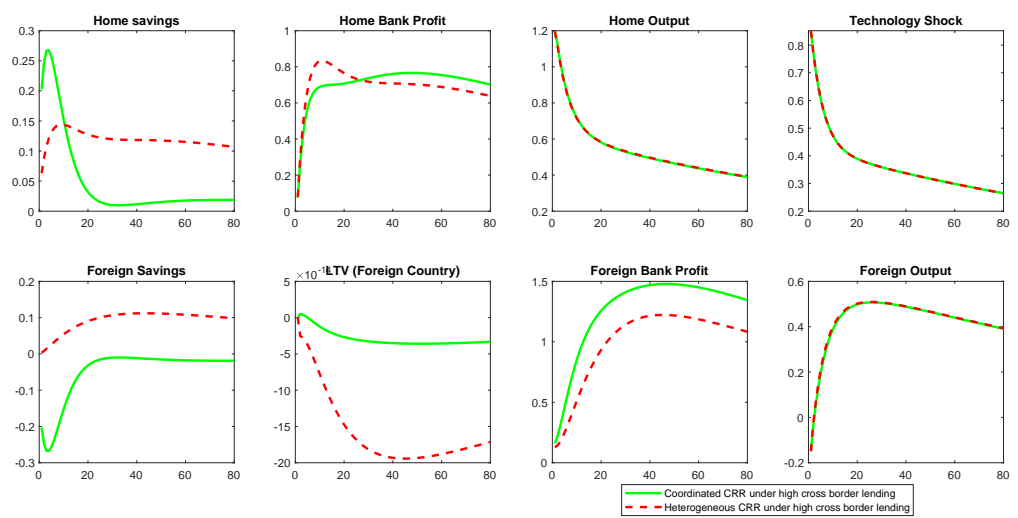

Note: Impulse responses to a one standard deviation technology shock in the home country. Green solid: coordinated capital requirements across countries under high cross border lending.. Red dashed line: Heterogeneous capital requirement under high cross-border lending, $\mathrm{Y}$ asix: \%Deviation from the steady state, $\mathrm{x}$ axis: Quarters.

Figure C.5. 3. International coordination of capital requirements (capital requirements are active and LTV ratios are constant)
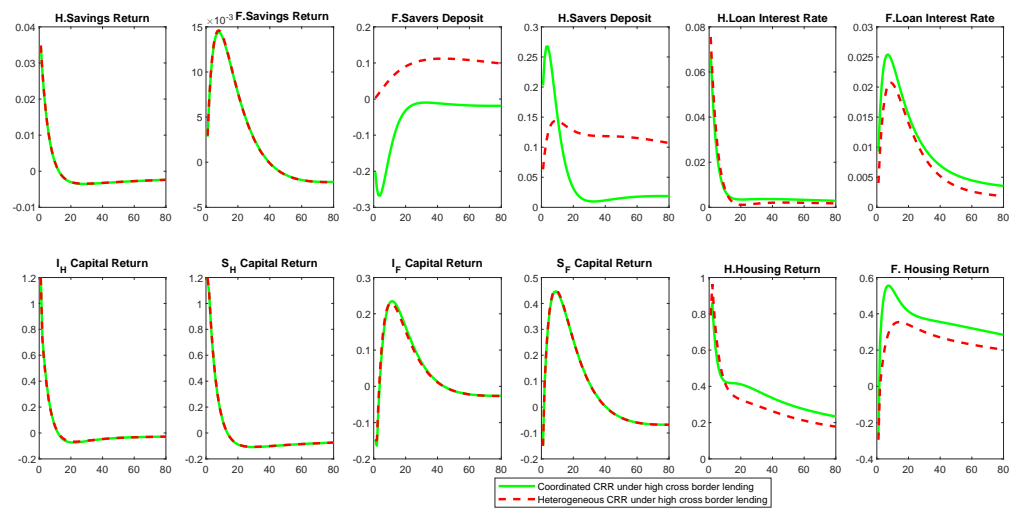

Note: Impulse responses to a one standard deviation technology shock in the home country. Green solid: coordinated capital requirements across countries under high cross border lending.. Red dashed line: Heterogeneous capital requirement under high cross-border lending, $\mathrm{Y}$ asix: \%Deviation from the steady state, $\mathrm{x}$ axis: Quarters.

Figure C.5. 4. International coordination of capital requirements (capital requirements are active and LTV ratios are constant) 

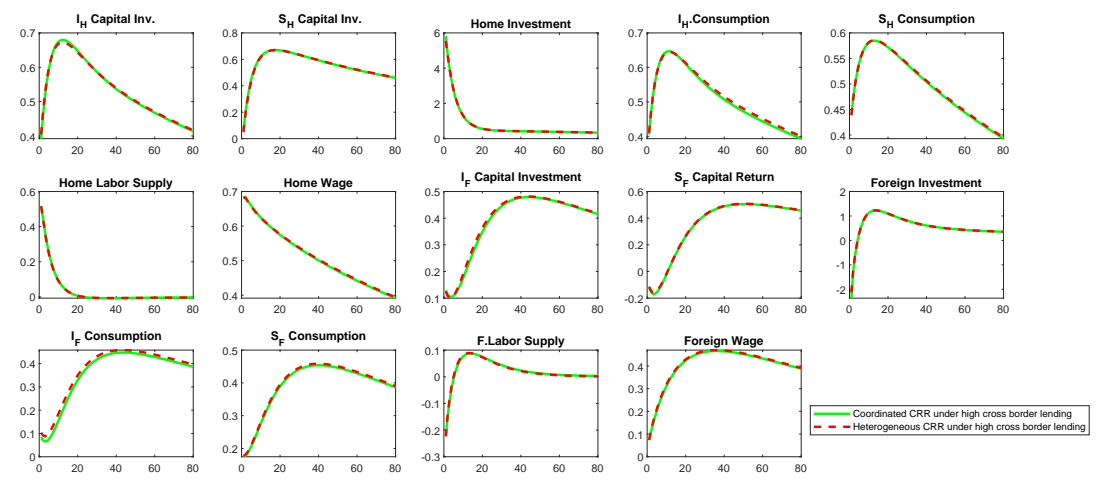

Note: Impulse responses to a one standard deviation technology shock in the home country. Green solid: coordinated capital requirements across countries under high cross border lending. Red dashed line: Heterogeneous capital requirement under high cross-border lending, Y asix: \%Deviation from the steady state, $\mathrm{x}$ axis: Quarters.

Figure C.5. 5. International coordination of capital requirements (capital requirements are active and LTV ratios are constant) 


\section{Figure C.6. Domestic productivity shock}
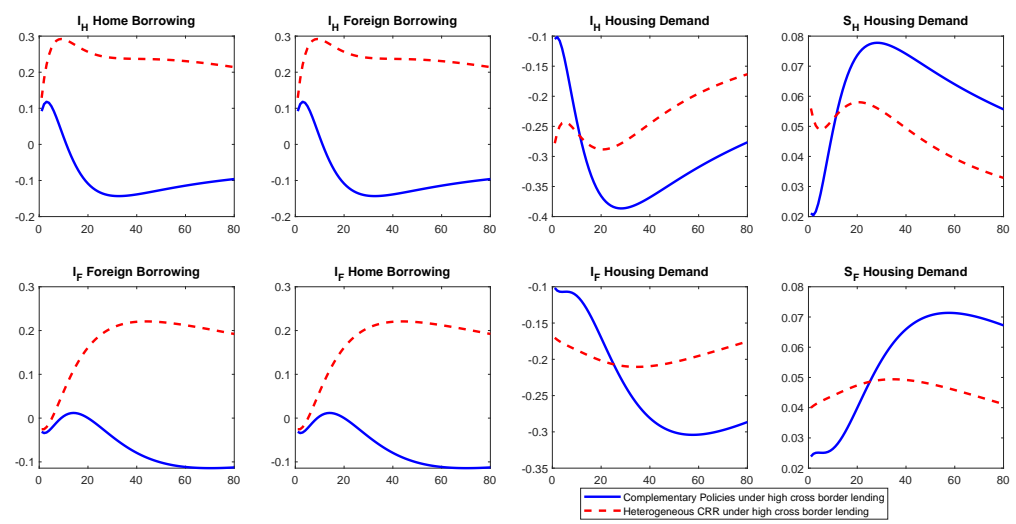

Note: Impulse responses to a one standard deviation technology shock in the home country. Blue solid line: Active LTV ratio and capital requirements within the home country. Red dashed line : Heterogeneous capital requirements under high cross-border lending. Y asix: \%Deviation from the steady state, $\mathrm{x}$ axis: Quarters.

Figure C.6.1 Time-varying LTV ratio and capital requirements
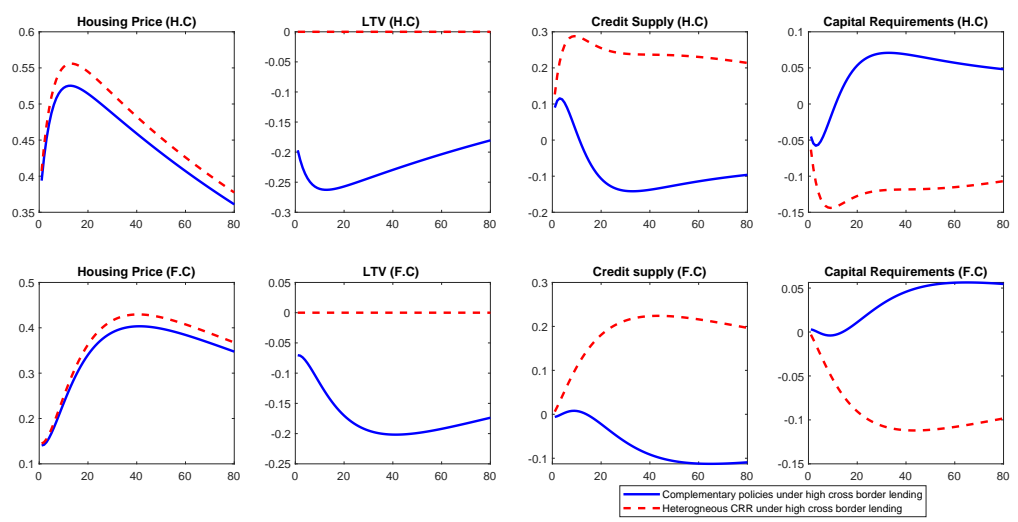

Note: Impulse responses to a one standard deviation technology shock in the home country. Blue solid line: Active LTV ratio and capital requirements within the home country. Red dashed line : Heterogeneous capital requirements under high cross-border lending. Y asix: \%Deviation from the steady state, $\mathrm{x}$ axis: Quarters.

Figure C.6.2. Time-varying LTV ratio and capital requirements 

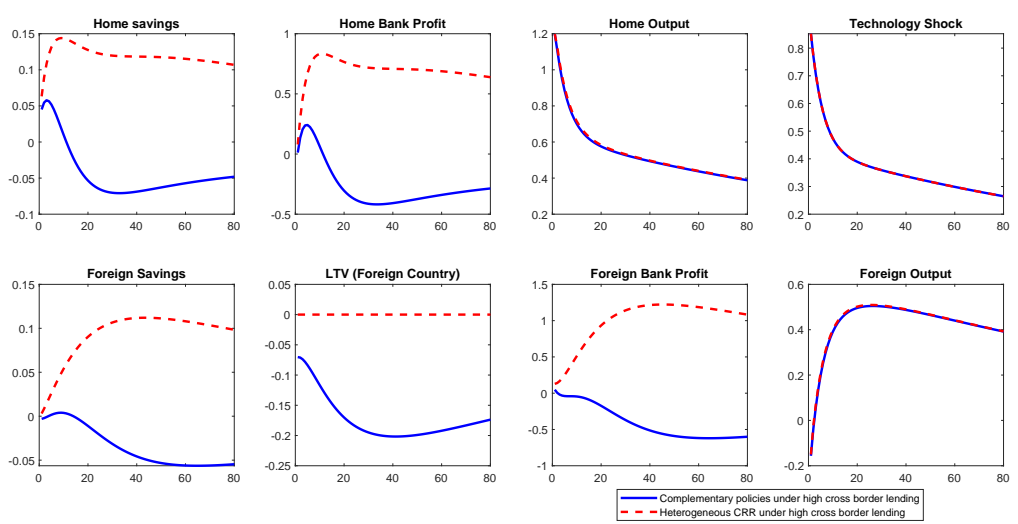

Note: Impulse responses to a one standard deviation technology shock in the home country. Blue solid line: Active LTV ratio and capital requirements within the home country. Red dashed line : Heterogeneous capital requirements under high cross-border lending. $\mathrm{Y}$ asix: \%Deviation from the steady state, $\mathrm{x}$ axis: Quarters.

Figure C.6.3. Time-varying LTV ratio and capital requirements
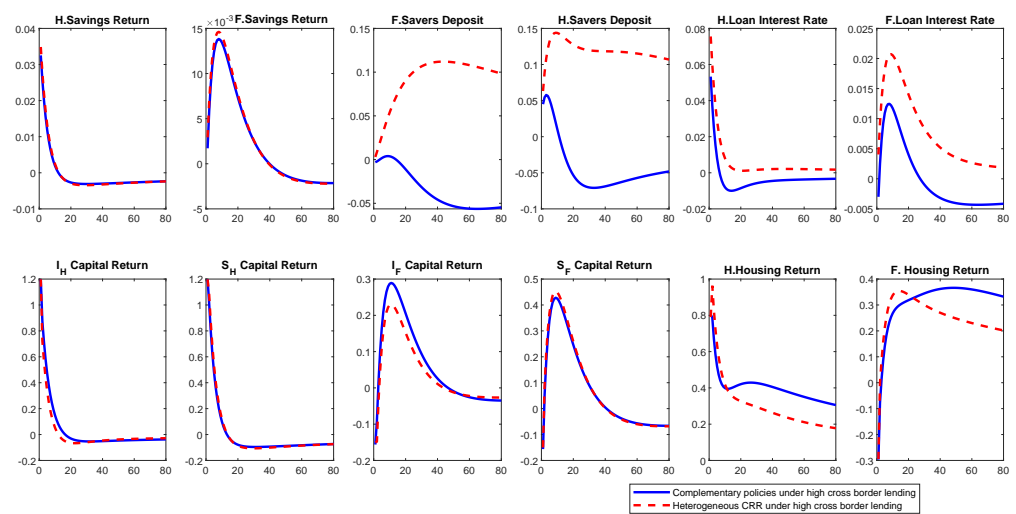

Note: Impulse responses to a one standard deviation technology shock in the home country.Blue solid line: Active LTV ratio and capital requirements within the home country. Red dashed line : Heterogeneous capital requirements under high cross-border lending. $\mathrm{Y}$ asix: \% Deviation from the steady state, $\mathrm{x}$ axis: Quarters.

Figure C.6.4. Time-varying LTV ratio and capital requirements 

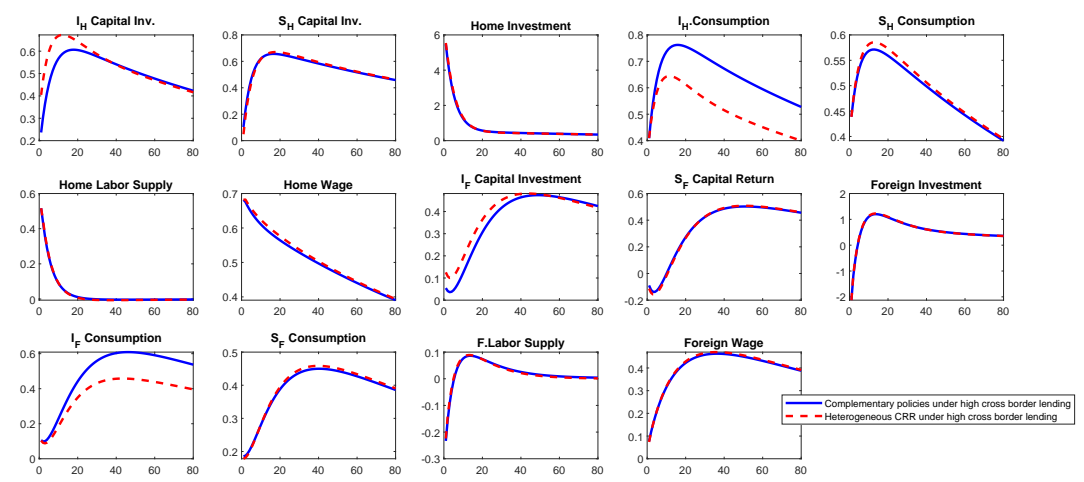

Note: Impulse responses to a one standard deviation technology shock in the home country. Blue solid line: Active LTV ratio and capital requirements within the home country. Red dashed line : Heterogeneous capital requirements under high cross-border lending. Y asix: \%Deviation from the steady state, $\mathrm{x}$ axis: Quarters.

Figure C.6.5. Time-varying LTV ratio and capital requirements 
Figure C.7. Domestic borrowing capacity shock
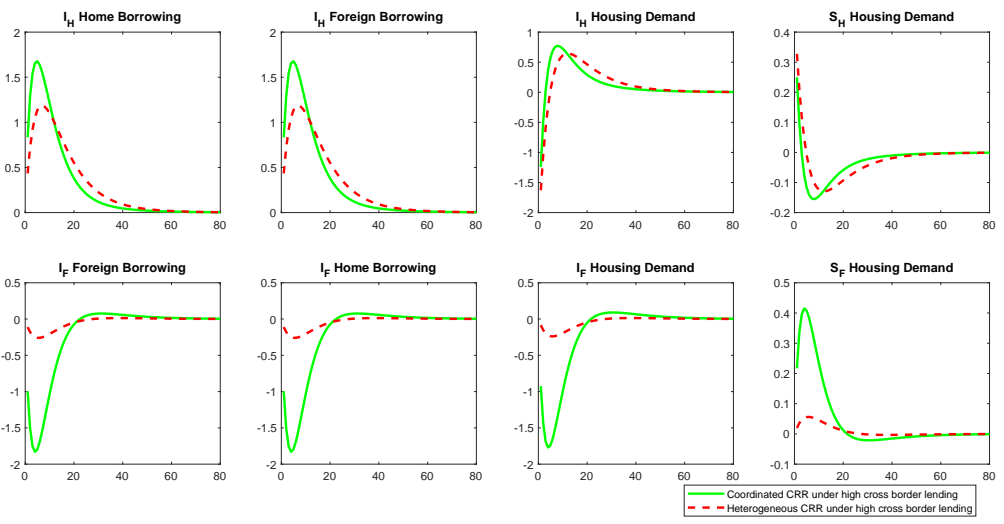

Note: Impulse responses to a one standard deviation borrowing capacity shock in the home country. Red dashed line coordinated capital requirements across countries under high cross border lending. Red dashed line: Heterogeneous capital requirements under high cross-border lending.. Y asix: \%Deviation from the steady state, $\mathrm{x}$ axis: Quarters.

Figure C.7.1. International coordination of capital requirements
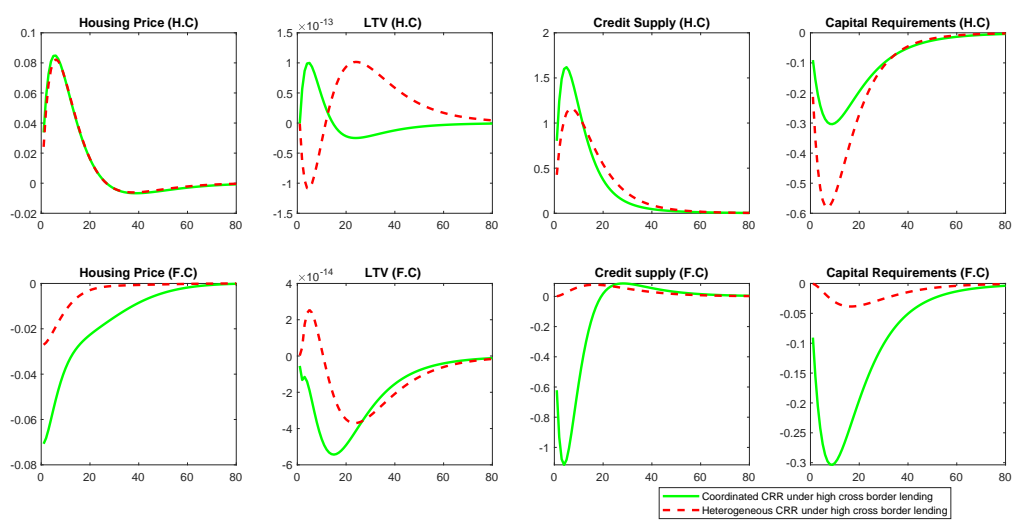

Note: Impulse responses to a one standard deviation borrowing capacity shock in the home country. Red dashed line coordinated capital requirements across countries under high cross border lending. Red dashed line: Heterogeneous capital requirements under high cross-border lending.. Y asix: \%Deviation from the steady state, $\mathrm{x}$ axis: Quarters.

Figure C.7.2. International coordination of capital requirements 

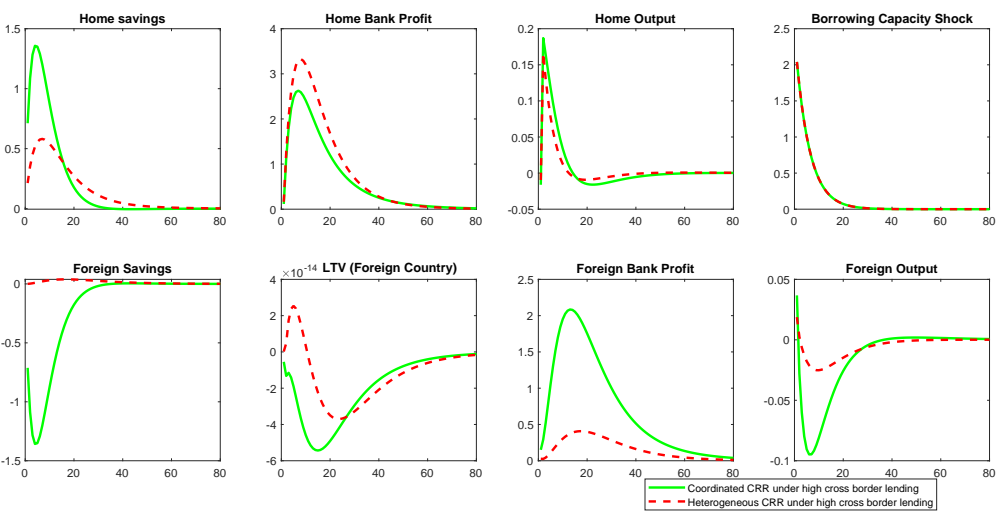

Note: Impulse responses to a one standard deviation borrowing capacity shock in the home country. Red dashed line Coordinated capital requirements across countries under high cross border lending. Red dashed line: Heterogeneous capital requirements under high cross-border lending. Y asix: \%Deviation from the steady state, $\mathrm{x}$ axis: Quarters.

Figure C.7.3. International coordination of capital requirements
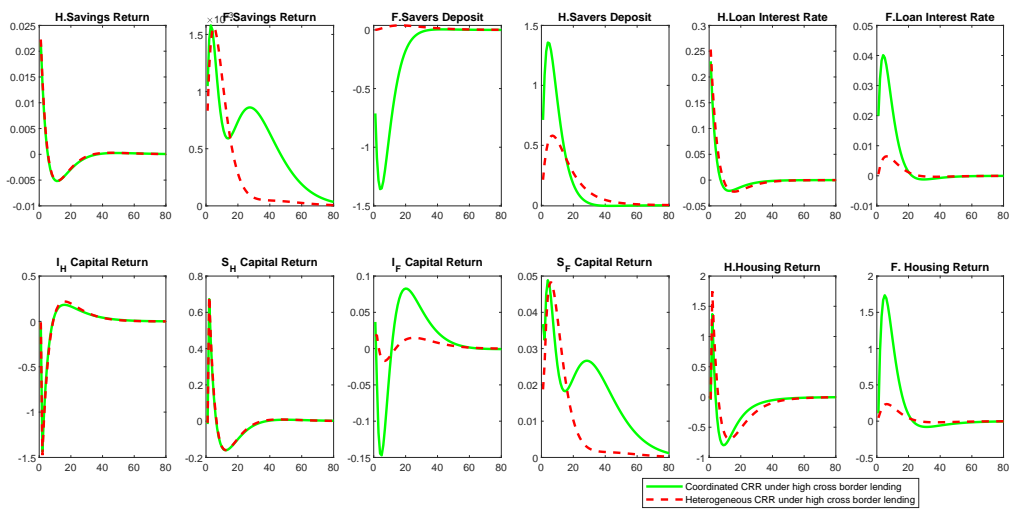

Note: Impulse responses to a one standard deviation borrowing capacity shock in the home country. Red dashed line Coordinated capital requirements across countries under high cross border lending. Red dashed line: Heterogeneous capital requirements under high cross-border lending. Y asix: \%Deviation from the steady state, $\mathrm{x}$ axis: Quarters.

Figure C.7.4. International coordination of capital requirements 

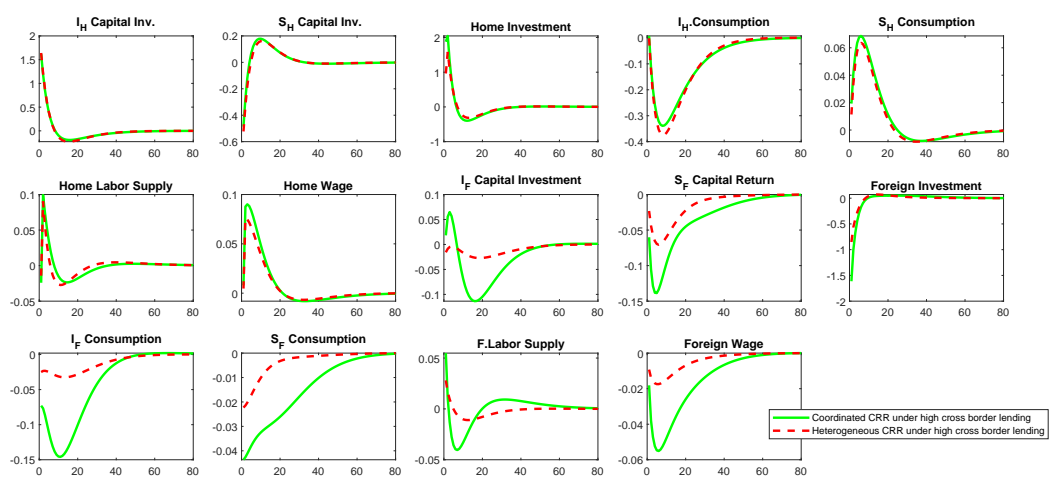

Note: Impulse responses to a one standard deviation borrowing capacity shock in the home country. Red dashed line Coordinated capital requirements across countries under high cross border lending. Red dashed line: Heterogeneous capital requirements under high cross-border lending. Y asix: \%Deviation from the steady state, $\mathrm{x}$ axis: Quarters.

Figure C.7.5. International coordination of capital requirements 
Figure C.8. Domestic borrowing capacity shock
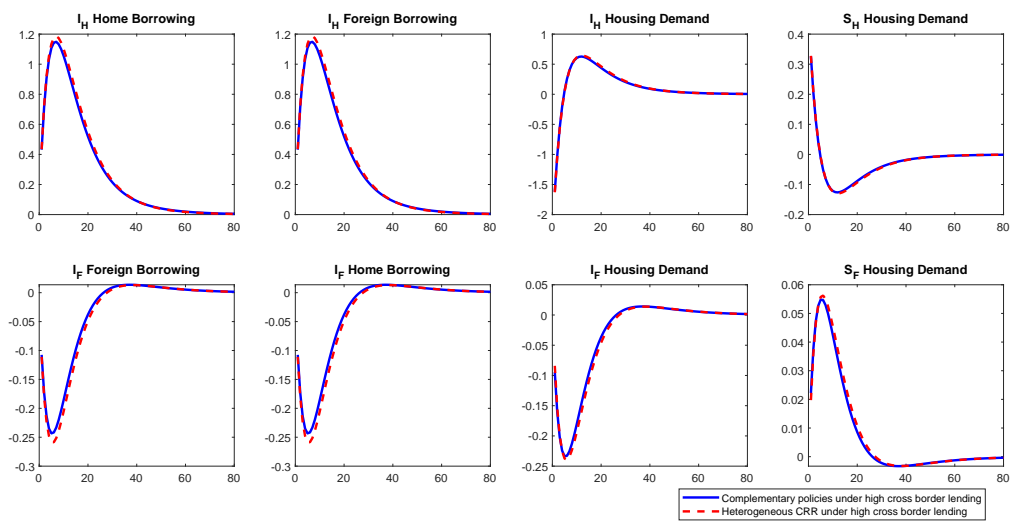

Note: Impulse responses to a one standard deviation borrowing capacity shock in the home country. Blue solid line: Active LTV ratio and capital requirements under high cross border lending Red dashed line: Heterogeneous capital requirements under high cross-border lending. Y asix: \%Deviation from the steady state, $\mathrm{x}$ axis: Quarters.

Figure C.8.1. Time Varying LTV ratio and capital requirements
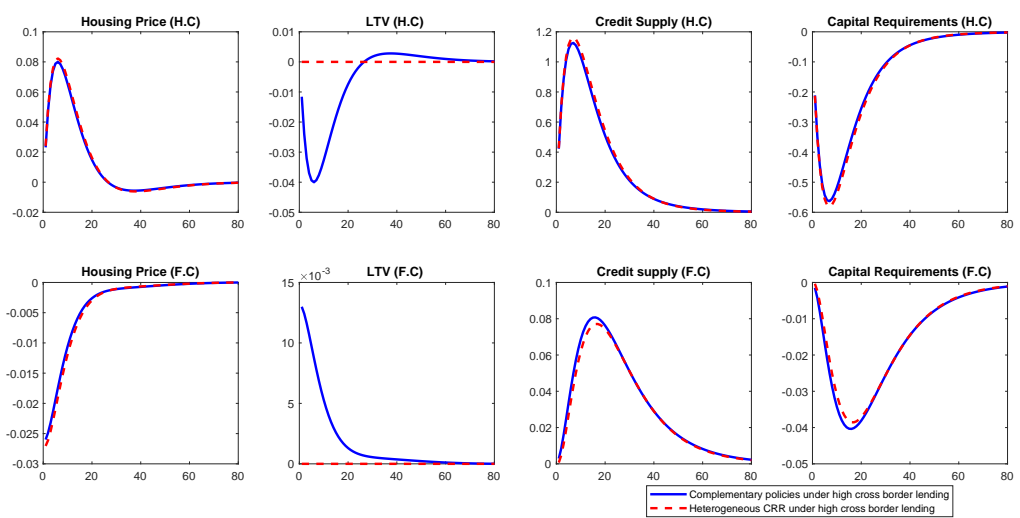

Note: Impulse responses to a one standard deviation borrowing capacity shock in the home country. Blue solid line: Active LTV ratio and capital requirements under high cross border lending Red dashed line: Heterogeneous capital requirements under high cross-border lending.

Figure C.8.2. Time Varying LTV ratio and capital requirements 

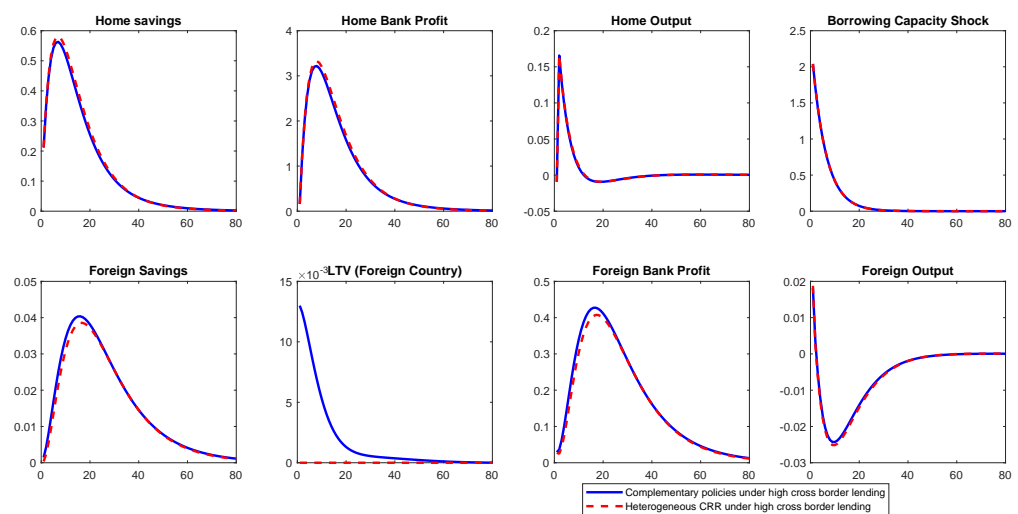

Note: Impulse responses to a one standard deviation borrowing capacity shock in the home country. Blue solid line: Active LTV ratio and capital requirements under high cross border lending Red dashed line: Heterogeneous capital requirements under high cross-border lending. $\mathrm{Y}$ asix: \%Deviation from the steady state, $\mathrm{x}$ axis: Quarters.

Figure C.8.3. Time Varying LTV ratio and capital requirements
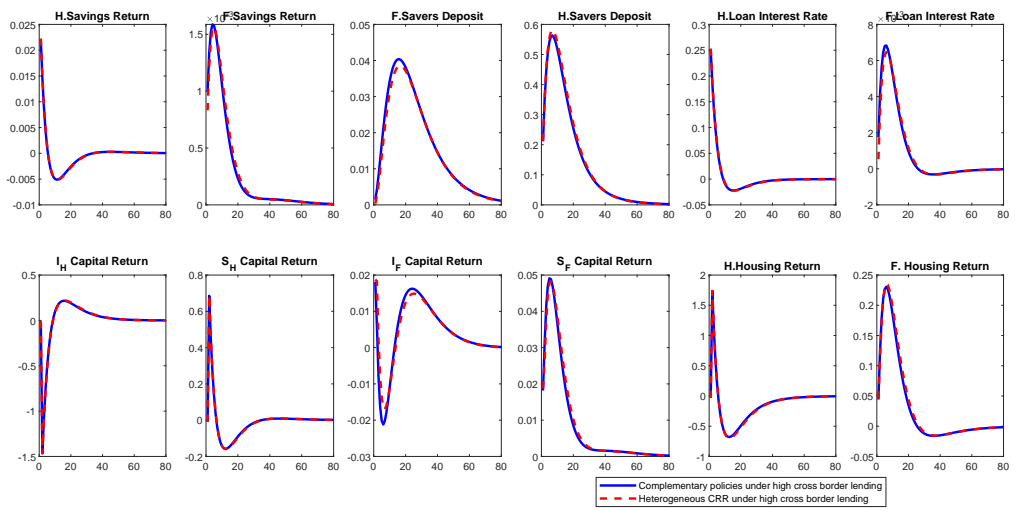

Note: Impulse responses to a one standard deviation borrowing capacity shock in the home country. Blue solid line: Active LTV ratio and capital requirements under high cross border lending Red dashed line: Heterogeneous capital requirements under high cross-border lending. Y asix: \%Deviation from the steady state, $\mathrm{x}$ axis: Quarters.

Figure C.8.4. Time Varying LTV ratio and capital requirements 

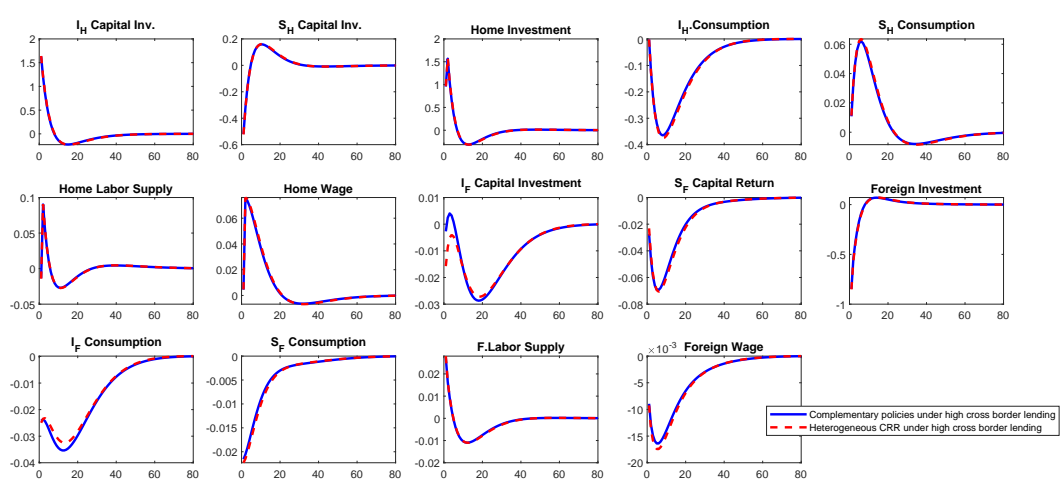

Note: Impulse responses to a one standard deviation borrowing capacity shock in the home country. Blue solid line: Active LTV ratio and capital requirements under high cross border lending Red dashed line: Heterogeneous capital requirements under high cross-border lending. Y asix: \%Deviation from the steady state, $\mathrm{x}$ axis: Quarters.

Figure C.8.5. Time Varying LTV ratio and capital requirements 


\section{Appendix D: Figures-Chapter 4}

Figure D.1. Domestic productivity shock
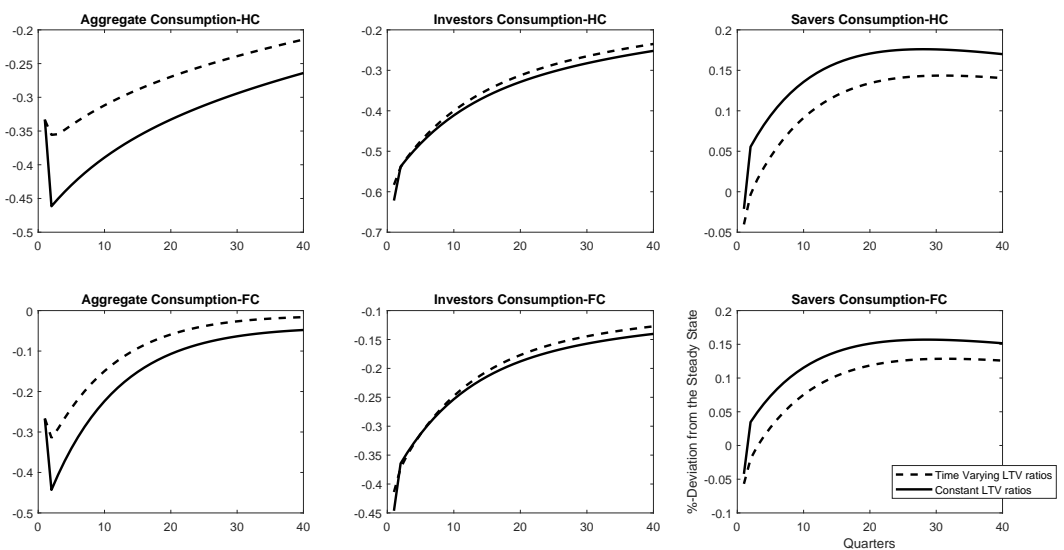

Figure D.1.1: Note: The solid line depicts responses to a negative productivity shock under constant LTV ratios and the dashed line represents the responses under time-varying LTV ratios. H C : Home Country, FC: Foreign Country.
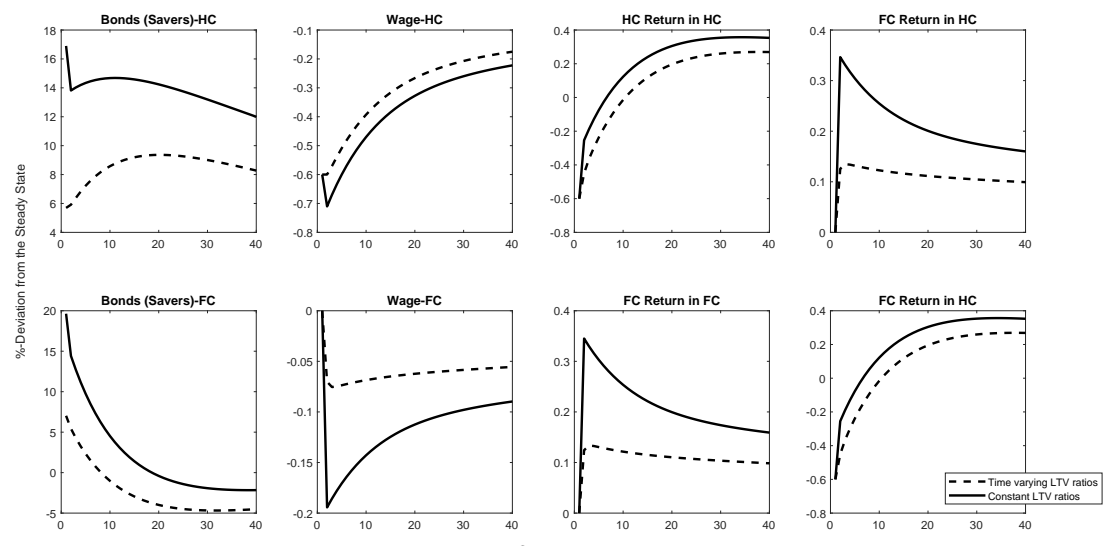

Figure D.1.2 :Note: The solid line depicts responses to a negative productivity shock under constant LTV ratios and the dashed line represents the responses under time-varying LTV ratios. H C : Home Country, FC: Foreign Country. 

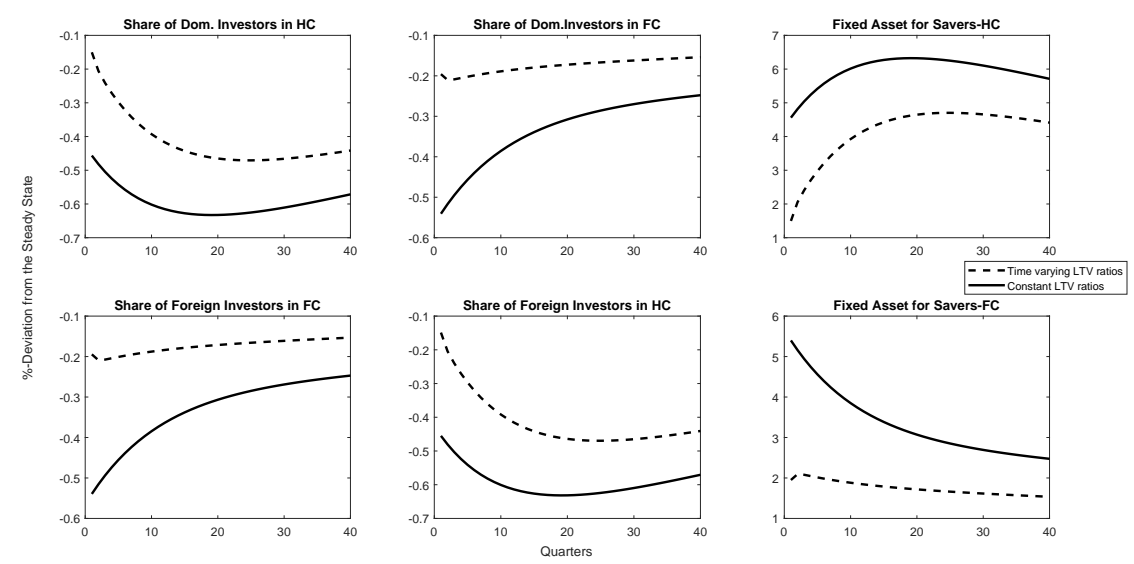

Figure D.1.3:Note: The solid line depicts responses to a negative productivity shock under constant LTV ratios and the dashed line represents the responses under time-varying LTV ratios. H C : Home Country, FC: Foreign Country.
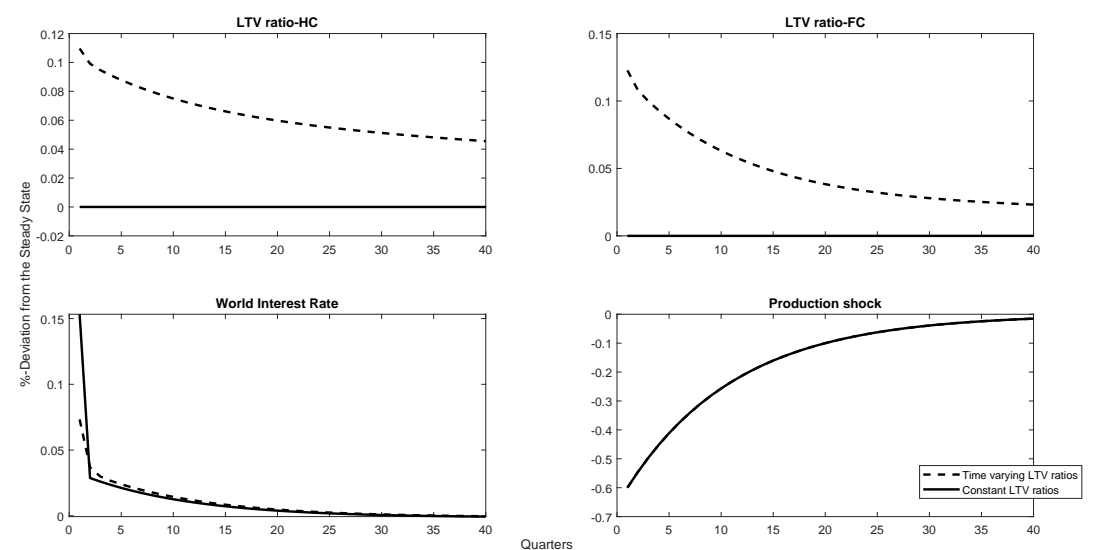

Figure D.1.4: Note: The solid line depicts responses to a negative productivity shock under constant LTV ratios and the dashed line represents the responses under time-varying LTV ratios. H C : Home Country, FC: Foreign Country.

\section{Figure D.2. Domestic borrowing capacity Shock}
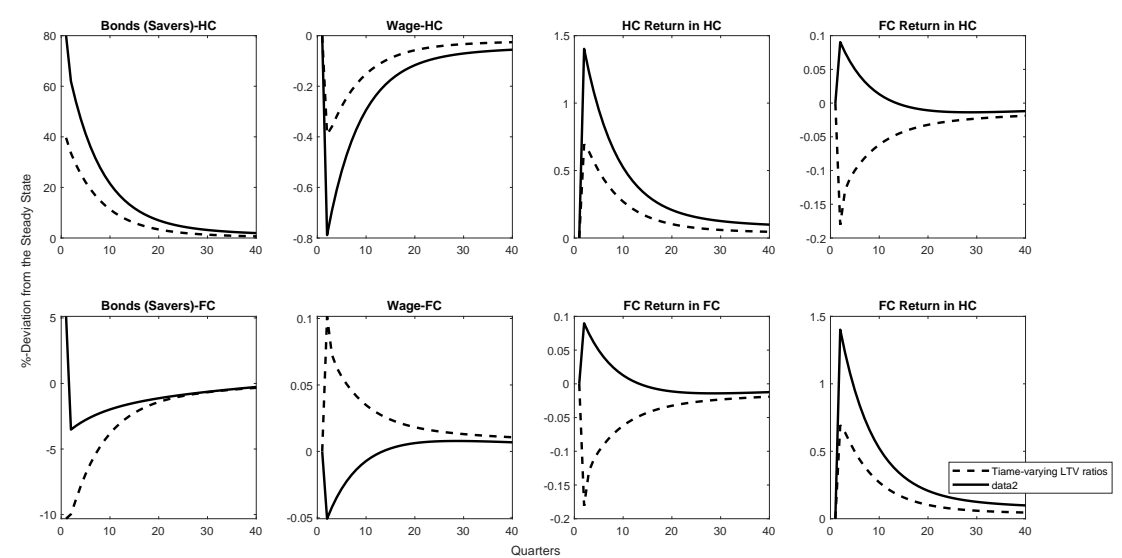

Figure D.2.1: Note: The solid line depicts responses to a negative productivity shock under constant LTV ratios and the dashed line represents the responses under time-varying LTV ratios. H C : Home Country, FC: Foreign Country. 

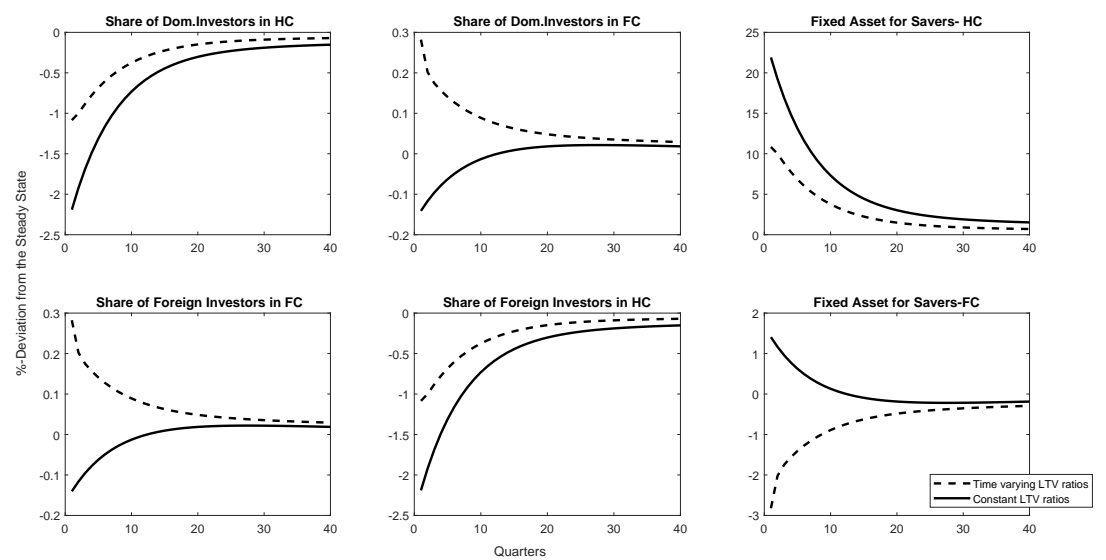

Figure D.2.2: Note: The solid line depicts responses to a negative productivity shock under constant LTV ratios and the dashed line represents the responses under time-varying LTV ratios. H C : Home Country, FC: Foreign Country.
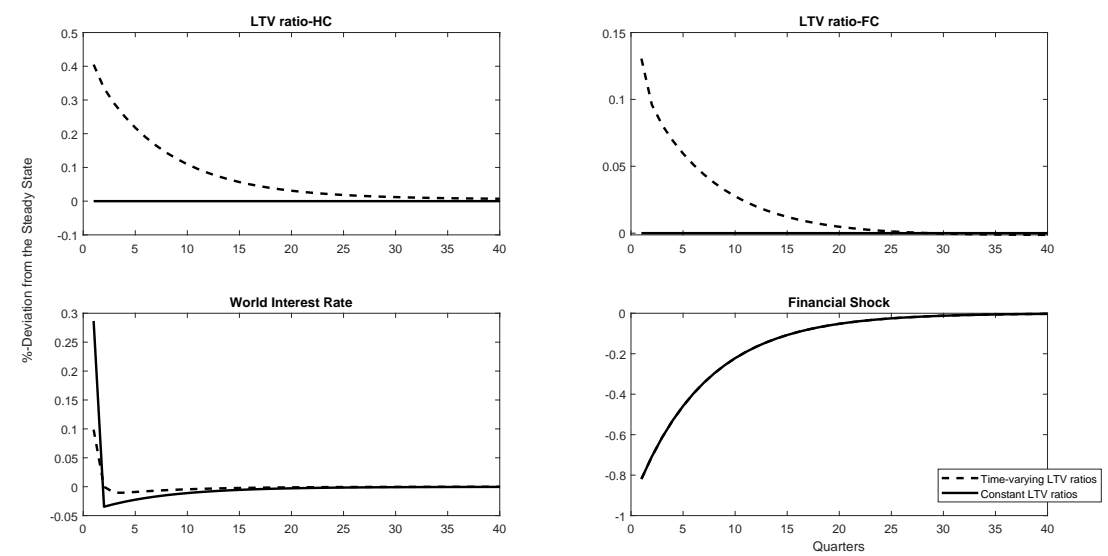

Figure D.2.3: Note: The solid line depicts responses to a negative productivity shock under constant LTV ratios and the dashed line represents the responses under time-varying LTV ratios. H C : Home Country, FC: Foreign Country.
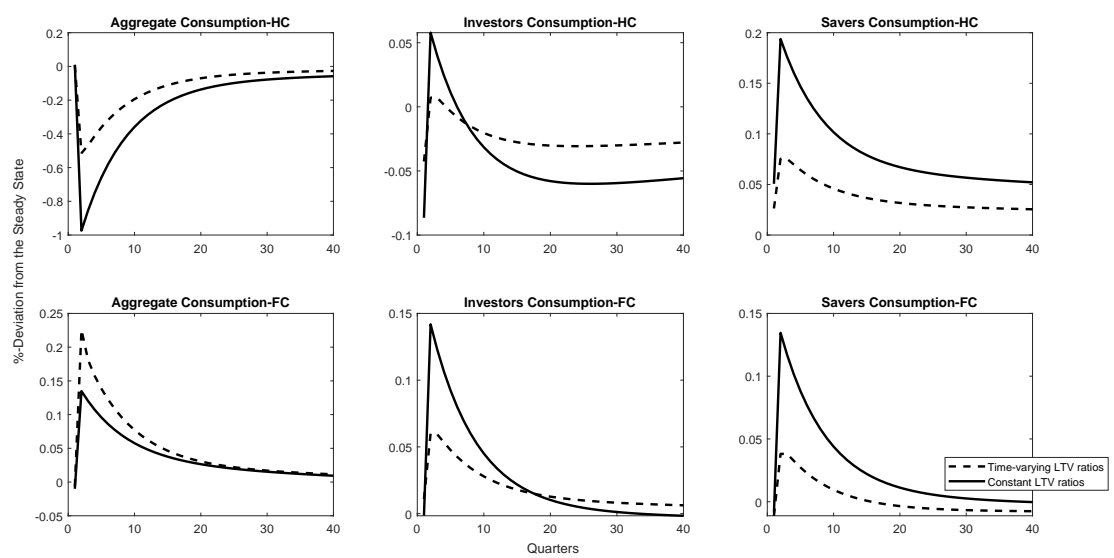

Figure D.2.4: Note: The solid line depicts responses to a negative productivity shock under constant LTV ratios and the dashed line represents the responses under time-varying LTV ratios. H C : Home Country, FC: Foreign Country. 


\section{Bibliography}

- Acharya, Viral V., 2003. Is the International convergence of capital adequacy regulation desirable? The Journal of Finance, Vol LVIII, No 6.

- Aiyar S., Calomiris, Charles W., Wieladek, T., 2012. Does Macro-Prudential leak? Evidence from UK policy experiment. NBER Working Paper series 17822.

- Aiyar, S., Calomiris, Charlers W., Wieladek, T., 2014a. Identifying channels of credit substitution when bank capital requirements are varied. Bank of England Working Paper No 485.

- Aiyar, S.,Calomiris, Charles W., Hooley, J., Korniyenko, Y., Wieladek, T., 2014b. The International transmission of bank capital requirements : Evidence from the United Kingdom. Bank of England Working Paper No 497.

- Akinci, O., Olmstead-Rumsey, J., 2015. How effective are macroprudential policies? An empirical investigation. Federal Reserve Board International Finance Discussion Papers 2015-1136 (May).

- Allen, F., Beck, T., Carletti, E., Lane, P., Schoenmaker, D., Wagner, W., 2011. Crossborder Banking in Europe: Implications for Financial Stability and Macroeconomic Policies. CEPR.

- Andres, J., Hurtado, S., Ortega E., and Thomas C., 2010. Spain in the euro: a general equilibrium analysis. Series 1,67-95. 
- Angelini, P., Neri S., Panetta, F., 2011. Monetary and Macroprudential Policies.European Central Bank. Working Paper Series No 1449.

- Avdjiev S., Gambacorta L., Goldberg, Linda S., Schiaffi, S., 2013. The shifting drivers of global liquidity. NBER Working Paper series 23565.

- Backus, David K., Kehoe, Patrick J., Kydland, Finn E., 1992. International real business cycles. The Journal of Political Economy, Vol 100 No 4, 745- 775.

- Bailliu J., Meh C., Zhang Y., 2015. Macroprudential rules and monetary policy when financial frictions matter. Economic Modelling 50, 148-161.

- Bank for International Settlement 2010. Basel III : A global regulatory framework for more resilient banks and banking systems. Bank for International Settlement.

- Bank for International Settlement 2011. Global liquidity - concept, measurement and policy implications. CGFS Papers No 45.

- Beau, D., Clerc, L., Mojon, B., 2011. Macroprudential policy and the conduct of monetary policy. Banque de France, Occasional Paper No 8.

- Beck T. , Todorov, T., Wagner, W., 2012. Supervising Cross-Border Banks : Theory, Evidence and Policy. European Banking Center Discussion Paper No. 2012-015.

- Beirne, J., Friedrich, C., 2017. Macroprudential policies, capital flows, and the structure of the banking sector. Journal of International Money and Finance 75,47-68.

- Bengui,J., 2014. Macroprudential Coordination. Manuscript.

- Bengui,J., Bianchi , J., 2014. Capital Flow Management when Capital Controls Leak. Manuscript.

- Benigno, G., Chen, H., Otrok, C., Rebucci, A., Young, Eric R., 2013.Financial crises and macro-prudential policies. Journal of International Economics 89 453-470. 
- Berrospide J., Correa, R. Goldberg L., Niepmann F., 2015. International Banking and Crossborder Effects of Regulation: Lessons from the United States. NBER Working Paper Series.

- Bianchi, J., 2011a. Overborrowing and Systemic Externalities in the Business Cycle. The American Economic Review, Vol.101 No7, pp 3400-3426.

- Bianchi, J., 2011b. Macro-prudential Policy in a Fisherian Model of Financial Innovation. 12th Jacques Polak Annual Research Conference.

- Bianchi, J., Mendoza, E., 2011. Overborrowing, Financial crises and Macroprudential policy. IMF Working paper WP /11/24.

- Boar, C., Gambacorta, L., Da Silva, L.P., Lombardo, G., 2017. What are the effects of macroprudential policies on macroeconomic performance? BIS Quarterly Review.

- Bremus F. and Fratzscher M. 2015. Drivers of structural change in cross-border banking since the global financial crisis. Journal of International Money and Finance 52 32-59.

- Bruneau, G., Christensen, I.,Meh, Cesaire A., 2016. Housing Market Dynamics and Macroprudential Policy. Bank of Canada, Staff Working paper 2016-31.

- Brzoza-Brzezina, M., Kolasa, M., Makarski, K.,2015. Macroprudential policy and imbalances in the euro area. Journal of International Money and Finance 51137-154.

- Buch, Claudia M., Goldberg, Linda S., 2016. Cross-Border prudential policy spillovers: How much? How important. Evidence from the International Banking Research Network. Manuscript.

- Buch, Claudia M., Goldberg, Linda S., 2017. Cross-border prudential policy spillover: How much? How important? Evidence from the international banking research network. International Journal of Central Banking.

- Cerutti, E., Correa, R., Fiorentino, E., Segalla, E., 2016. Changes in prudential policy instruments - A new Cross- Country Database. IMF Working Paper No 16/110. 
- Claessens S., Dell'Ariccia G., Igan D. and Laeven L. 2010. Cross-country experiences and policy implications from the global financial crisis. Economic Policy, Volume 25, Issue 62, Pages 267-293.

- Clerc, L., Derviz, A., Mendicino, C., Moyen, S., Nikolov, K., Stracca, L., Suarez, J., Vardoulais, A., 2014. Capital Regulation in a Macroeconomic Model with Three Layers of Default. Working paper, European System of Central Banks.

- Coeurdacier, N., Kollman, R., Martin,P., 2010. International Portfolios, capital accumulation and foreign assets dynamics,Journal of International Economics 80 100-112.

- Damar, H.E., Mordel, A., 2016. International Banking and Cross-Border Effects of Regulation: Lessons from Canada. Staff Working Paper 2016 - 34.

- De Nicolò,G., Favara, G., Ratnovski, L., 2012. Externalities and Macroprudential Policy. IMF Staff Discussion Note. SDN/12/05.

- De Paoli, B., Paustian, M., 2013. Coordinating Monetary and Macroprudential Policies. Federal Reserve Bank of New York. Staff Reports. No 653.

- Dedola, L., Lombardo, G., 2012. Financial frictions, financial integration and the international propagation of shocks. Econ. Policy 27 (70), 319-359.

- Dell'Ariccia, G., Marquez R., 2006. Competition among regulators and credit market integration. Journal of Financial Economics 79 401-430.

- Devereux, M.B., Yetman, J., 2010. Leverage constraints and the international transmission of shocks. J. Money Credit Bank. 42 (6), 71-105.

- Devereux, M.B., Yu, C.,2014. International financial intergration and crisis contagion. NBER Working Papers Series. Working Paper 20526.

- Drehman M., Juselius, M., 2012. Do debt service costs affect macroeconomic and financial stability. BIS Quarterly Review. 
- Drehman, M., Juselius, M., 2013. Evaluating early warning indicators of banking crises: Satisfying policy requirements. BIS Working Papers No 421.

- European Banking Authority, 2015. 2015 - EU-Wide Transparency exercise - Aggregate Report 2015.

- Faia, E., Weder di Mauro, B., 2015. Cross-border resolution of Global Banks. Discussion paper - European Commission. ISSN 2443-8022.

- Figuet, J-M., Humblot, T., Lahet, D., 2015. Cross-border banking claims on emerging countries: The Basel III Banking Reforms in a push and pull framework. Journal of International Financial Markets, Institutions \& Money 294-310.

- Frost J., de Haan J., Neeltje van Horen., 2016. International banking and cross- border effects of regulation: lessons from the Netherlands. DNB Working Paper No 520

- Gambacorta,L., Murcia, A., 2017. The impact of macroprudential policies and their interaction with monetary policy: an empirical analysis using credit registry data. BIS Working Papers No 636.

- Gelian, P., Ibas, P., 2017. Monetary and macroprudential policies in an estimated model with financial intermediation. Journal of Economic Dynamics \& Control 78, 164-189.

- Goetz, Martin R., Laeven, L., Levine, R., 2016. Does the geographic expansion of banks reduce risk? Journal of Financial Economic Vol. 120, Issue 2, 346-362.

- Hills R., Reinhardt D., Rhiannon Sowerbutts, R.,Tomasz Wieladek, T.,2016. Cross-border regulatory spillovers: How much? How important? What sectors? Lessons from the United Kingdom. Bank of England. Staff Working Paper No. 595.

- Houston, J. F., Lin, C., Ma, Y., 2012. Regulatory Arbitrage and International Bank Flows. Journal of Finance 67 (5), 1845- 1895. 
- Iacoviello, M., 2015.Financial Business Cycles. Review of Economic Dynamics.

- Iacoviello, M., Minetti , R., 2006. International business cycles with domestic and foreign lenders. Journal of Monetary Economics. 53 2267-2282.

- IMF, 2013. Key Aspects of Macroprudential Policy. International Monetary Policy.

- IMF, 2014. Staff Guidance Note on Macroprudential Policy - Detailed Guidance on Instruments.International Monetary Policy.

- IMF, 2015a. International Banking After The Crisis: Increasingly Local and Safer ? International Monetary Policy.

- IMF, 2017a. Global financial stability report : Getting the Policy Mix Right. International Monetary Policy.

- IMF, 2017b.Global financial stability report: Is Growth At Risk? International Monetary Policy.

- In’t Veld, J., Pagano,A., Raciborski,R., Ratto, M., Roeger, W., 2012. Imbalances and rebalancing scenarios in an estimated structural model for Spain.' European Economy - Economic Papers 458.

- Jacome, Luis I., Mitra, S., 2015. LTV and DTI Limits - Going granular. IMF Working Paper $15 / 154$.

- Jeanne, O., 2013. Macroprudential Policy in a Global Perspective. Working paper JHU.

- Jeanne, O., Korineck, A., 2010. Excessive Volatility in Capital Flows : A Pigouvian Taxation Approach. The American Economic Review, Vol.100, No2, pp 403-407.

- Kannan, P., Rabanal, P., 2012. Monetary and Macroprudential Policy Rules in a Model with House Price Booms. The B.E. Journal of Macroeconomics, Vol. 12, Iss.1 (Contributions), Art. 16. 
- Kannan, P., Rabanal, P., Scott, Alasdair M., 2012 .Monetary and Macroprudential Policy rules in a Model with House Price Boom. The B.E. Journal of Macroeconomics.

- Kara, Gazi I., 2016. Systemic Risk, International Regulation and the Limits of Coordination. Journal of International Economics 99, 192-222.

- Kiyotaki, N., Moore, J., 1997. Credit Cycles. Journal of Political Economy. Vol 105, No 2.

- Klomp, J., De Haan, J., 2011. Banking risk and regulation: Does one size f it all?. CPB Discussion Paper No 164.

- Kollman, R., Enders, Z., Muller, Gernot J., 2011. Global banking and international business cycles. European Economic Review 55, 407-426.

- Kuttner, Kenneth N., Shim, I., 2013. Can non-interest rate policies stabilize housing markets? Evidence from a panel of 57 economies. BIS Working Papers No 433.

- Lim, Cheng H., Columba F., Costa, A., Kongsamut, P., Otani, A., Saiyid, M., Wezel, T., Wu, X., 2011. Macroprudential Policy: What instruments and how are they used? Lessons from country experiences. IMF Working Paper 11/238.

- Mendicino, C., Punzi, M.T., 2014. House prices, capital inflows and macroprudential policy. Journal of Banking \& Finance 49, 337-355.

- Neanidis, C., 2017. Volatile capital flows and economic growth: The role of banking supervision. Journal of Financial Stability.

- Obstfeld, M., Rogoff, K., 2009. Global Imbalances and the Financial Crisis : Products of Common Causes. CEPR, Discussion Papers No 7606.

- Ohls J., Pramor M., Tonzer, L., 2016. International banking and cross-border effects of regulation: lessons from Germany. Discussion Paper Deutsche Bundesbank No 27/2016. 
- Ostry, Jonathan D., Ghosh, Atish R., Korinek, A, 2012. Multilateral aspects of managing the capital account. IMF, SDN 12/10.

- Perri, F., Quadrini, V., 2017. International recessions, American Economic Review (forthcoming).

- Poutineau, Jean C., Vermendel, G., 2015. Cross-border banking flows spillovers in the Eurozone: Evidence from an estimated DSGE model. Journal of Economic Dynamics and Control 51, 378-403.

- Punzi, Maria T., Rabitsch, K., 2015. Investor borrowing heterogeneity in a Kiyotaki- Moore style macro model. Economic Letters 130, 75- 79.

- Rabanal, P., Quint, D., 2013. Monetary and Macroprudential Policy in an Estimated DSGE Model of the Euro Area. IMF Working Paper. WP/13/209

- Reinhardt, D., Sowerbutts, R., 2015. Regulatory arbitrage in action: evidence from banking flows and macroprudential policy. Staff Working Paper No. 546.

- Reinhart, Carmen.M., Rogoff, Kenneth.S., 2013. Banking crises: An equal opportunity menace. Journal of Banking \& Finance Journal of Banking \& Finance 374557-4573.

- Rubio, M., 2014a. Housing-market heterogeneity in a monetary union. Journal of International Money and Finance 40 163-184.

- Rubio, M., 2014b. Macroprudential Policy Implementation in a Heterogeneous Monetary Union. Centre for Finance and Credit and Macroeconomics. Working paper 14/03.

- Rubio, M., 2016. Coordinating macroprudential policies within the Euro area: The case of Spain. Economic Modelling 59 570-582.

- Schwarcz, Steven L., 2008. Systemic risk. The Georgetown Law Journal. Vol 97:193 -249. 
- Trani,T., 2015. Asset pledgeability and international transmission of financial shocks. Journal of International Money and Finance 50, 49-77.

- Ueda., K., 2012. Banking Globalization and International business cycles : Cross-border chained credit contracts and financial accelerators. Journal of International Economics 861 16.

- Vermeulen, R., 2011. International diversification during the financial crisis. A blessing for equity investors? DNB Working Paper No 324/2011. Wold, Ella G., Juelsrud. Ragnar E., 2016. The consequences of increasing risk-based capital requirements for banks: Evidence from 2013 policy reform in Norway. Manuscripts.

- World Economic Outlook, 2008 . Housing and the Business Cycle. International Monetary Fund. 